UNIVERSIDADE DE SÃo PAULO

Departamento de GenÉtica e Biologia Evolutiva

ANÁLISE TRANSCRIPTÔMICA DAS GLÂNDULAS DE VENENO DA MICRURUS CORALLINUS (COBRA-CORAL) E IDENTIFICAÇÃO DE CANDIDATOS ANTIGÊNICOS PARA UM ANTI-SORO ALTERNATIVO

LUCIANA IWANAGA LEÃO

SÃo PAULO 2008 
UNIVERSIDADE DE SÃo PAULO

Departamento de GenÉtica e Biologia Evolutiva

\section{ANÁLISE TRANSCRIPTÔMICA DAS GLÂNDULAS DE VENENO DA MICRURUS CORALLINUS (COBRA-CORAL) E IDENTIFICAÇÃO DE CANDIDATOS ANTIGÊNICOS} PARA UM ANTI-SORO ALTERNATIVO

Dissertação apresentada ao Instituto de Biociências da Universidade de São Paulo, para a obtenção de Título de Mestre em Ciências, na Área de Genética e Biologia Evolutiva.

Orientador: Dr. Inácio de Loiola Meirelles Junqueira de Azevedo

LUCIANA IWANAGA LEÃO

SÃo PAULO

2008 
Leão, Luciana I.

Análise transcriptômica das glândulas de veneno de Micrurus corallinus (cobra-coral) e identificação de candidatos antigênicos para um anti-soro alternativo

$127 \mathrm{p}$.

Dissertação (Mestrado) - Instituto de

Biociências da Universidade de São Paulo.

Departamento de Genética e Biologia Evolutiva.

1. Micrurus corallinus 2. Anti-soro antielapídico 3. Transcriptoma I. Universidade de São Paulo. Instituto de Biociências. Departamento de Genética e Biologia Evolutiva.

\section{Comissão Julgadora:}

$\operatorname{Prof}(a) \cdot \operatorname{Dr}(a)$

$\operatorname{Prof}(a) \cdot \operatorname{Dr}(a)$.
$\operatorname{Prof}(a) \cdot \operatorname{Dr}(a)$

Prof(a). Dr(a).

Prof(a). Dr.(a).

Orientador(a) 
À minha mãe, Yako, e a meu pai, Luiz Aos meus irmãos, Cris e Du

E ao meu querido Marcelo 
Ever tried. Ever failed.

No matter.

Try again. Fail again.

Fail better.

-Samuel Beckett, Worstward Ho

Non est ad astra mollis e terris via.

—Sêneca, Hercules Furens

Au milieu de l'hiver, j'ai découvert en moi un invincible été.

—Albert Camus, Noces à Tipasa 


\section{Agradecimentos}

Ao Dr. Inácio de L. M. Junqueira de Azevedo, que me ensinou a correr atrás dos meus objetivos. Sua orientação, neste trabalho, garantiu que eu aprendesse a ser uma pesquisadora independente. Agradeço a oportunidade de ter trabalhado com toxinas de animais no Instituto Butantan e ter feito parte desse campo tão promissor.

Ao Dr. Paulo Lee Ho, pela biblioteca de cDNA de Micrurus corallinus. Sem ela, esse projeto não teria acontecido.

Ao Dr. Geraldo Magalhães, pelo esforço despendido para me ajudar com as transfecções.

Aos colegas de laboratório e técnicos, que direta ou indiretamente me ajudaram em algum momento do meu projeto. Agradeço especialmente à Débora e Ágatha, que me ajudaram muito nesse último ano do projeto, e ao Enéas de Carvalho, por todos os conselhos metodológicos.

Aos meus grandes amigos Henrique Ramos, Vivian Hashimoto, Patrícia Diniz e Erika Nakajima, pela amizade incondicional. Ao Rico e Vivis, obrigada também pela ajuda nas imunizações e nas sangrias.

Ao Giuseppe Puorto, pela grande amizade e pelas aulas sobre serpentes e animais peçonhentos. Aprendi a ter outro olhar para esse mundo herpetológico. Obrigada.

À minha família, pelo carinho e preocupação em todos os momentos da minha vida. Ao meu pai, Dr. Luiz Eduardo V. Leão, por me compreender e me aconselhar sempre com as palavras de quem entende de ciência e pesquisa. À minha mãe, Yasuko, por me ajudar e ter paciência com a bagunça que ficou a sala de estar dela.

Ao meu querido Marcelo Yamashita Salles, que me ajudou em todos os momentos desde que estamos juntos. Agradeço seu companheirismo, a tolerância e os ombros para chorar. Obrigada por estar ao meu lado nos momentos mais difíceis, especialmente nesse final de projeto. Obrigada por usar grande parte do seu tempo para editar a minha dissertação e deixá-la mais do que perfeita. Sem você, esse trabalho não se concretizaria. Obrigada, Má.

Ao Instituto Butantan, que me acolheu e me ajudou nesses quatro anos em que estive trabalhando nele.

À FAPESP, CNPq e Fundação Butantan pelo suporte financeiro. 


\section{Sumário}

1. INTRODUÇÃO............................................................................ 9

1.1 SERPENTES PRODUTORAS DE VENENOS............................................ 9

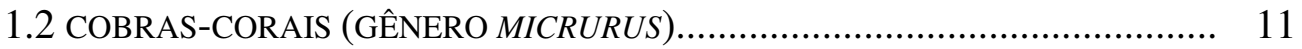

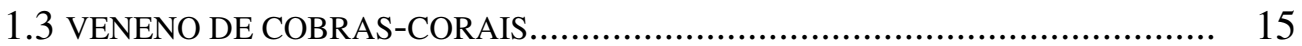

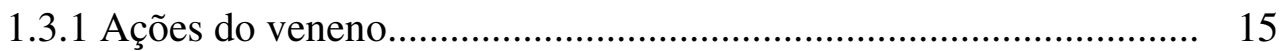

1.3.2 Ação Neurotóxica e Miotóxica..................................................... 15

1.3.3 Ação Hemorrágica....................................................................... 16

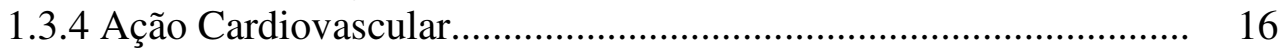

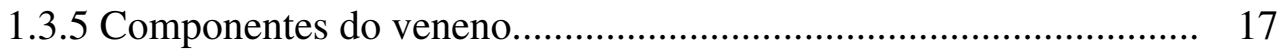

1.3.6 Envenenamento por cobras-corais............................................... 19

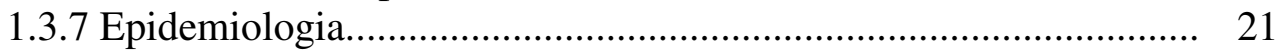

1.4 SOROS ANTIVENENO DE SERPENTES................................................. 23

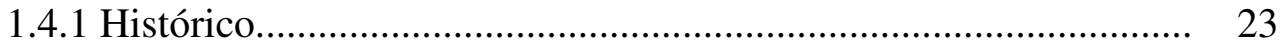

1.4.2 A produção do soro antielapídico................................................ 24

1.5 IMUNIZAÇÃO GENÉTICA OU VACINA DE DNA...................................... 26

1.6 TRANSCRIPTOMAS DE GLÂNDULAS DE VENENOS................................... 27

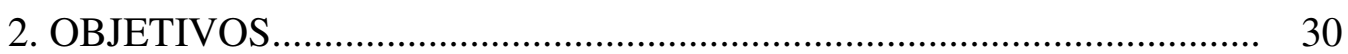

3. MATERIAL E MÉTODOS.................................................................. 31

3.1 PREPARO DE FAGOS PARA GERAÇÃO DE ESTS...................................... 31

3.1.1 Biblioteca de Micrurus corallinus (fago $\lambda$ gt11D)......................... 31

3.1.2 Preparação da bactéria E. coli Y1088 ........................................... 31

3.1.3 Preparação do fago ( $\lambda$ gt11D-GI e $\lambda$ gt11D-GII)........................... 31

3.1.4 Montagem das placas para fagos................................................... 31

3.1.5 Amplificação do cDNA contido no fago (PCR) ........................... 32

3.1.6 Seqüenciamento dos clones....................................................... 32

3.1.7 Análise das seqüências expressas................................................ 33

3.2 CLONAGEM DOS CANDIDATOS ANTIGÊNICOS PARA IMUNIZAÇÃO GENÉTICA (VACINA DE DNA)............................................................. 34

3.2.1 Os candidatos antigênicos..................................................... 34

3.2.2 Estratégia de clonagem........................................................ 34

3.2.2.1 Desenho de primers........................................................... 35

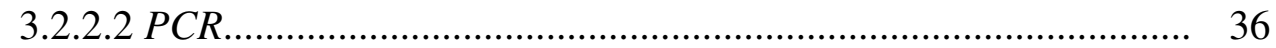

3.2.2.3 Clonagens em PGEM-T......................................................... 36

3.2.2.4 Digestão com BamHI e EcoRI................................................. 37

3.2.2.5 Subclonagem em pSecTag2A................................................ 37

3.3 PROCESSO PRÉ-IMUNIZAÇÃO GENÉTICA.......................................... 38

3.3.1 Maxiprep dos candidatos antigênicos para imunização genética.. 38

3.3.2 Transfecção de clones em células eucarióticas............................ 38

3.4 IMUNIZAÇÃO DOS CANDIDATOS ANTIGÊNICOS ESCOLHIDOS................ 39

3.5 EXPRESSÃO E PURIFICAÇÃO DAS PROTEÍNAS RECOMBINANTES............. 40

3.6 ANÁLISE DA RESPOSTA IMUNOLÓGICA …......................................... 42

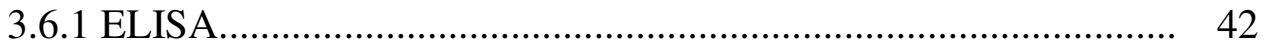

3.6.2 Western Blot.......................................................................... 43

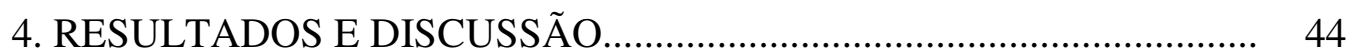




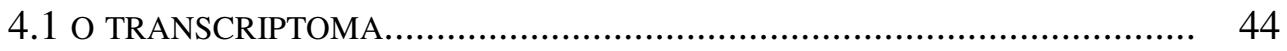

4.1.1 Banco de Seqüências................................................................. 44

4.1.2 Análise dos cDNAs de toxinas identificados no banco de ESTs.. 49

4.1.2.1 Proteína de três dígitos......................................................... 50

4.1.2.2 Fosfolipase do tipo A2 ........................................................... 52

4.1.2.3 Lectinas do tipo C............................................................... 55

4.1.2.4 Peptídeo Natriurético........................................................... 59

4.1.2.5 L-aminoácido oxidase ........................................................... 61

4.1.2.6 Inibidor do tipo Kunitz....................................................... 61

4.1.2.7 Metaloprotease .................................................................. 62

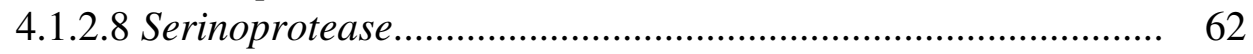

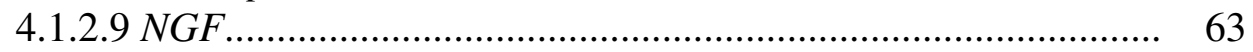

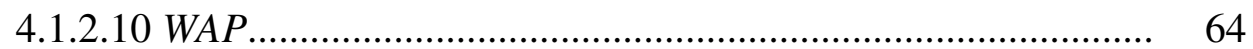

4.2 IMUNIZAÇÃO GENÉTICA................................................................ 65

4.2.1 Escolha de candidatos antigênicos a partir do transcriptoma de

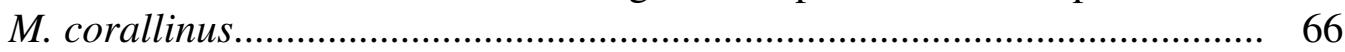

4.2.2 Clonagem dos candidatos antigênicos para imunização genética. 69

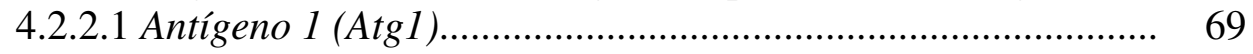

4.2.2.2 Antígeno 2 (Atg2)............................................................ 71

4.2.2.3 Antígeno 3 (Atg3)........................................................... 72

4.2.2.4 Antígeno 4 (Atg4)............................................................... 73

4.2.2.5 Antígeno 5 (Atg5).............................................................. $\quad 74$

4.2.3 Transfecção preliminar de clones em células eucarióticas e

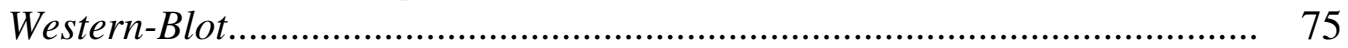

4.2.4 Expressão e purificação das proteínas recombinantes.................. 78

4.2.4.1 Candidato antigênico Atg1(Proteína V8)................................ 78

4.2.4.2 Candidato antigênico Atg2 (proteína V1).................................. 79

4.2.4.3 Candidato antigênico Atg5 (Proteína V2)............................. 79

4.2.5 A imunização genética (ou vacina de DNA) em camundongos.... 81

4.2.6 Análise da resposta imune........................................................... 82

4.2.7 Imunização tripla com três candidatos antigênicos...................... 87

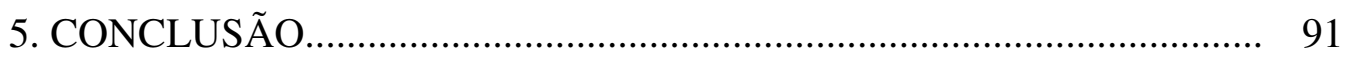

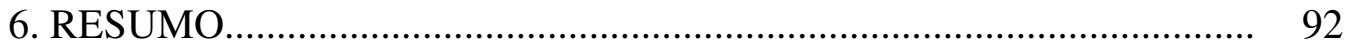

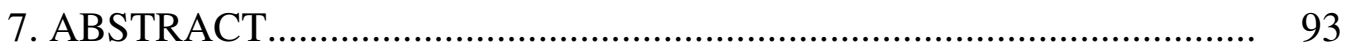

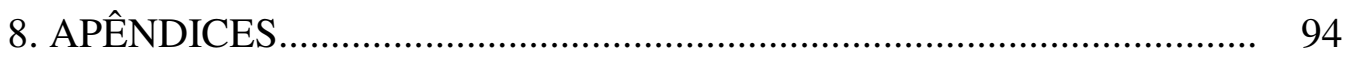

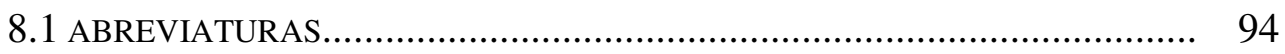

8.2 ÍNDICE DE FIGURAS............................................................. 96

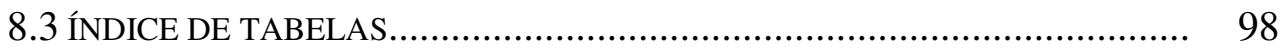

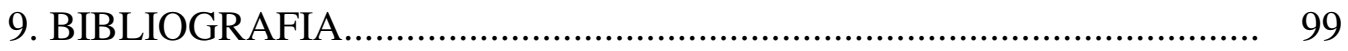

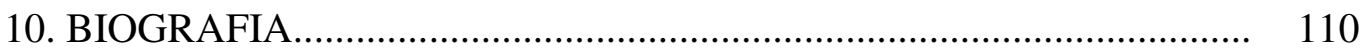

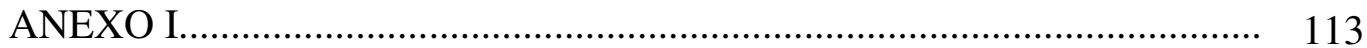




\section{INTRODUÇÃO}

\subsection{SERPENTES PRODUTORAS DE VENENOS}

Os ofídios, ou as serpentes, compõem a Subordem Serpentes, que atualmente apresenta cerca de 3.200 espécies. É a segunda subordem mais abundante depois de Sauria (lagartos e lagartixas), que possui 4.636 espécies. As serpentes fazem parte da Ordem Squamata, o principal e mais numeroso grupo de répteis existente. Elas são encontradas em quase todo o mundo e habitam regiões temperadas e tropicais, pela sua dependência do calor externo para efetuar a termorregulação.

As serpentes usam o veneno para paralisar e matar suas presas ou para se defender de predadores. Os componentes tóxicos desses venenos têm ações rápidas e seletivas muito potentes, que interferem em mecanismos fisiológicos, celulares e moleculares específicos. Cada veneno apresenta uma ação particular característica da espécie da serpente, decorrente dos tipos de toxinas que o compõem e do tipo específico de presa a que é dirigido. Entretanto, o veneno também pode agir de forma eficaz em outros alvos da dieta ou possíveis em predadores da serpente.

Dentre as mais de 3.200 espécies de serpentes existentes, apenas 420 espécies são peçonhentas, ou seja, utilizam seu veneno para caçar e são capazes de inoculá-lo (Dowling \& Duellman, 1978) (Figura 1A). Essas serpentes peçonhentas se agrupam em quatro famílias:

- Família Atractaspididae - composta por duas subfamílias: Aparalactinae (de dentição opistóglifa) e Atractaspidinae (de aparelho inoculador semelhante à dentição solenóglifa). A subfamília Atractaspidinae é composta pelo gênero Atractaspis. O veneno dessas serpentes se caracteriza por conter sarafotoxinas de potente ação cardiotóxica e vasoconstritora, semelhante à das endotelinas.

- Família Viperidae - abrange as serpentes venenosas que apresentam dentição solenóglifa, ou seja, dentes inoculadores de veneno frontais e móveis. Estes dentes são ocos e é por onde passa o tubo inoculador de veneno. Uma característica principal das serpentes da Família Viperidae é a presença de fosseta loreal, ou seja, um órgão termorreceptor para captação do calor. 
- Família Colubridae - algumas serpentes desta família podem ser consideradas venenosas, pois apresentam glândula produtora de veneno, apesar de terem dentição opistóglifa, ou seja, apresentarem um par de dentes posteriores por onde o veneno escorre e pode vir a ser inoculado. Por causa da posição dos dentes, essas serpentes raramente causam acidentes.

- Família Elapidae - composta por cerca de 300 espécies, distribuídas em 62 gêneros. Estas serpentes têm dentição denominada proteróglifa. A maxila é fixa e não permite a mobilidade dos dentes inoculadores. $\mathrm{O}$ veneno é caracterizado por apresentar ações neurotóxicas. Os representantes desta Família não possuem fosseta loreal (Figura1B). A esta família pertencem as cobras-corais brasileiras do gênero Micrurus estudadas neste projeto, e por isso ela será mais bem detalhada adiante.

Todas essas famílias pertencem à Infraordem Caenophidia, ou "serpentes avançadas", um clado diverso que contém mais de $80 \%$ das espécies de serpentes do mundo (KEOGH et al., 1998).

A Família Elapidae está amplamente distribuída por toda a faixa intertropical do planeta (SLOWINSKI et al., 1997) e forma o principal grupo de serpentes venenosas. Elas apresentam presas e glândulas de veneno e algumas são considerados os animais mais perigosos e temidos do mundo. Porém a maioria dos elapídeos são serpentes pequenas e difíceis de serem encontradas, tais como as serpentes do gênero Micrurus, que se acham por toda a região da América.

Duas subfamílias são reconhecidas: Elapinae e Hydrophiinae (KEOGH et al., 1998). Os elapines representam aproximadamente 225 espécies de serpentes terrestres que podem ser encontradas nos trópicos e, eventualmente, nos subtrópicos de algumas regiões. Nesta subfamília encontram-se as serpentes do Velho Mundo, tais como as cobras indianas (Naja), a cobra-rei (Ophiophagus), a kraits (Bungarus) e as mambas (Dendroaspis). Três gêneros ocorrem no Novo Mundo: Leptomicrurus, Micrurus e Micruroides (também denominadas cobras-corais) (CAMPBELL \& LAMAR, 2004). A maioria dos elapines é ovípara, com exceção de alguns gêneros africanos e australianos vivíparos.

Os hidrofines são representados pelas serpentes marinhas. A subfamília contém aproximadamente setenta espécies. As serpentes marinhas podem ser encontradas nas 
águas tropicais da Índia e do Oceano Pacífico Oeste. Elas apresentam algumas especializações que caracterizam as serpentes desta subfamília. Todas possuem glândula de sal ao redor da língua, que funciona como regulador osmótico. O corpo é, em geral, comprimido lateralmente, tem a cauda bastante desenvolvida, narinas com válvula de fechamento e uma série de adaptações anatômicas e comportamentais. São vivíparas e os filhotes nascem dentro da água (CAMPBELL \& LAMAR, 2004).

\subsection{COBRAS-CORAIS (GÊNERO MICRURUS)}

As cobras-corais são os únicos elapídeos em toda a América. Micrurus é o gênero mais representativo em abundância e diversidade dos elapídeos do Novo Mundo, amplamente distribuídos e encontrados desde o sudoeste dos Estados Unidos, passando pela América Central até o centro sul da Argentina (Dowling \& Duellman, 1978). Muitos dos elapídeos são encontrados na Bacia Amazônica, principalmente em regiões com baixa densidade populacional (CARDOSO et al., 2003).

Entre as serpentes venenosas, quase todas as espécies de Micrurus dependem de ambientes florestais. O gênero possui espécies que apresentam atividade diurna e noturna, e há as predominantemente diurnas, como a M. corallinus da Mata Atlântica.

As serpentes são animais ectotérmicos, isto é, sua temperatura corpórea depende da temperatura do ambiente externo. Entretanto, por meio do comportamento, são capazes de manter sua temperatura dentro de amplitudes muito menores que as variações de temperatura ambiente. Elas conseguem isso pela busca de locais adequados para se aquecer ou resfriar, e/ou pela posição e postura de seu corpo (MARQUES \& SAZIMA, 1997).

As cobras-corais possuem alimentação especialista, isto é, se alimentam de um único ou poucos tipos de presas. A maioria das espécies de cobras-corais se alimenta prioritariamente de serpentes menores (especialmente colubrídeos e tiflopídeos), mas elas também podem se alimentar de gimnofionas e anfisbenas. Dessa forma, sua alimentação é denominada dieta ofiófaga e estenofágica, ou seja, alimentam-se de presas específicas, geralmente animais vermiformes, o que inclui outras serpentes (CAMPBELl \& LAMAR, 2004).

Muitas espécies de serpentes possuem um padrão de cores com faixas transversais, manchas e outros desenhos. Essa estratégia lhes proporciona camuflagem e dificulta sua localização por predadores orientados visualmente. As cobras-corais, muito 
venenosas, se utilizam de tática diferente: em vez de se camuflar, exibem cores vistosas. Seu colorido vivo alerta o predador para o risco que corre caso ataque a serpente. Diversas espécies de colubrídeos não venenosos (falsas-corais) imitam (mimetizam) o padrão de colorido das cobras-corais verdadeiras, uma estratégia para enganar e afastar o predador (MARQUES \& SAZIMA, 1997). Os predadores aprendem, por experiência, a associar o padrão de coloração apossemática dessas serpentes com uma experiência desagradável e/ou traumática. Este esforço adaptativo garante às serpentes a proteção contra predadores que aprendem a evitar esse padrão particular de coloração.

As 61 espécies de cobras-corais atualmente reconhecidas são divididas em três gêneros: Micrurus (57 espécies), Leptomicrurus (três espécies) e Micruroides (uma espécie) (Figura 2). O Micrurus pode ser encontrado em habitats terrestres do sul dos EUA até o sul da América do Sul. A Leptomicrurus é encontrado nas regiões baixas tropicais e nas florestas úmidas amazônicas. O monotipo Micruroides é encontrado apenas no Deserto Sonoran no sudoeste dos EUA e no nordeste do México (SLOWINSKI, 1995).

Foram realizados diversos estudos filogenéticos desse grupo. Pesquisas bioquímicas e morfológicas evidenciaram que as cobras-corais apresentam uma relação mais próxima com outros elapídeos do que com os colubrídeos (SLOWINSKI, 1995). ROZE (1987) apresentou uma árvore filogenética de cobras-corais naquele que foi a primeira publicação sobre relação entre as cobras-corais (Figura 3). A filogenia proposta por Roze inseriu o Micruroides como um grupo irmão de todas as outras corais, divididas em Leptomicrurus e Micrurus. O grupo seguinte deu origem a mais uma divisão: M. mipartitus e as outras Micrurus. Este último grupo foi separado em grupo Monodal (seqüência de faixas alternadas vermelha-amarela-preta-amarela-vermelha) e o grupo Triadal da América do Sul, caracterizada por uma seqüência de cores diferenciadas (vermelha-preta-amarela-preta-amarela-preta-vermelha) (SLOWINKI, 1995). 

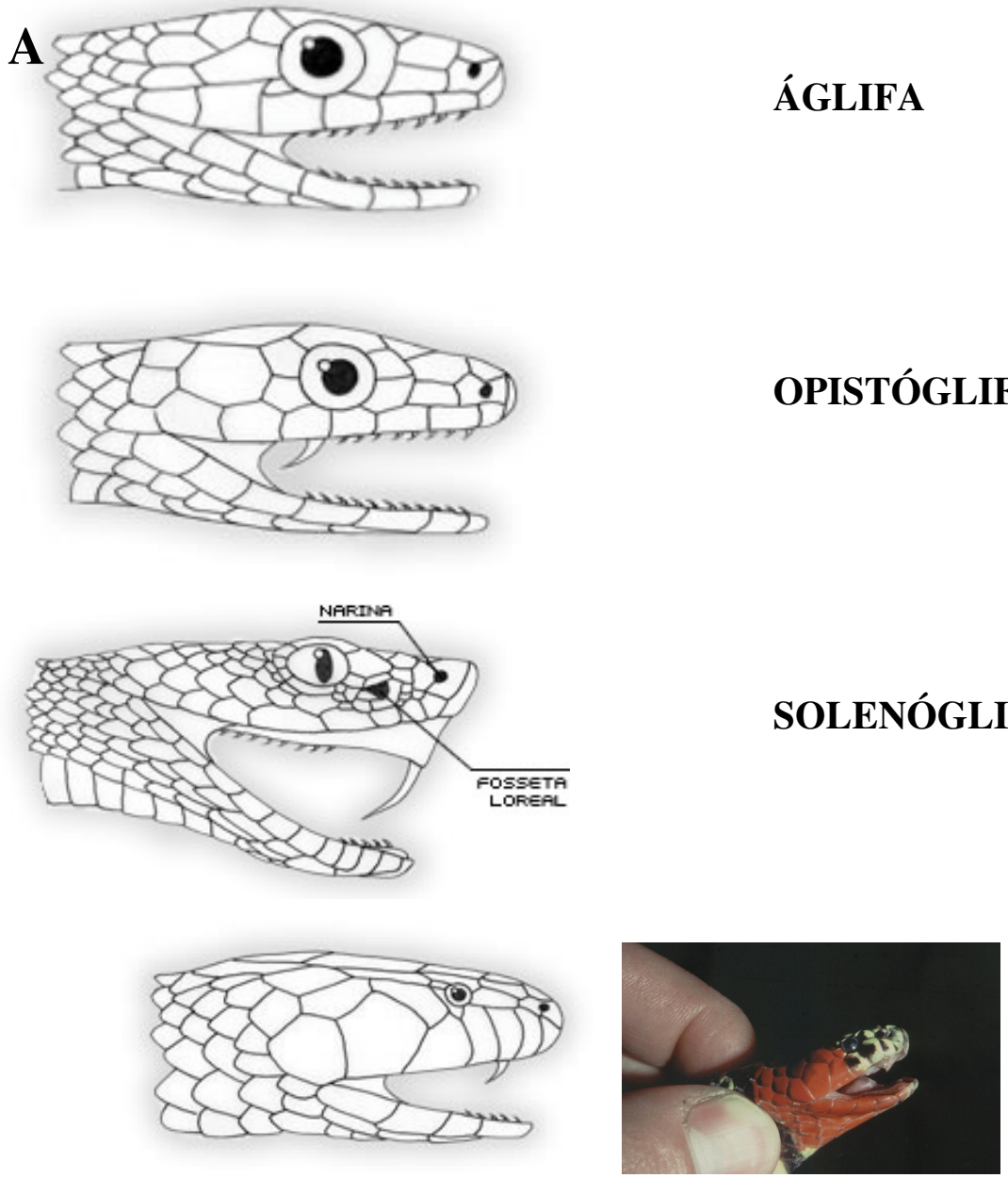

PROTERÓGLIFA

B

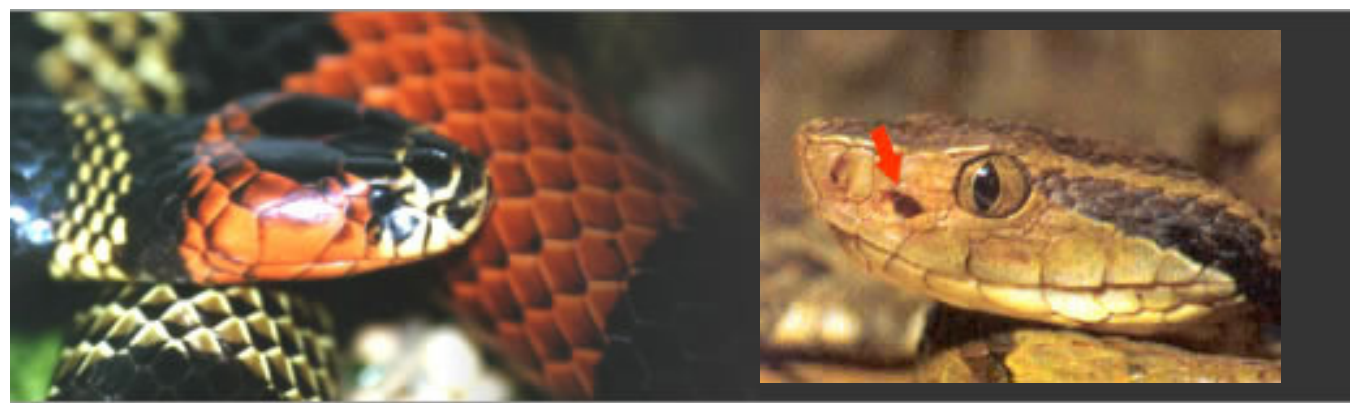

Elapidae (M. corallinus)

Figura 1: A) Quatro principais tipos de dentições encontradas entre as Famílias de Serpentes Atractaspididae, Viperidae, Colubridae e Elapidae. B) Ausência da fosseta loreal nos elapídeos e comparação com os viperídeos. 


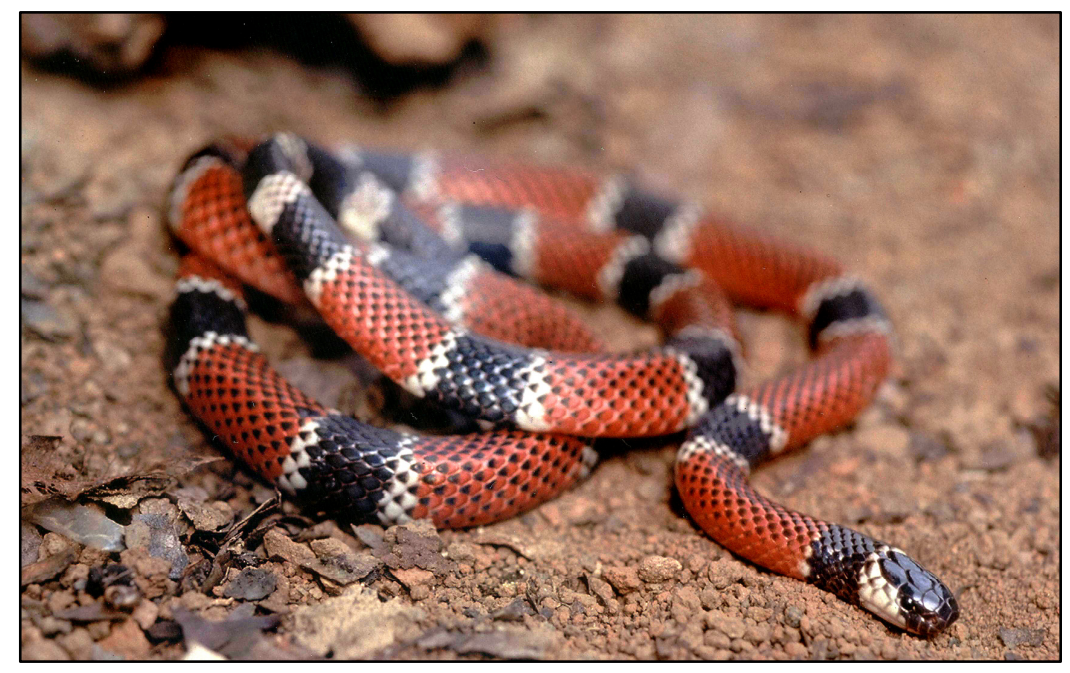

Micrurus corallinus

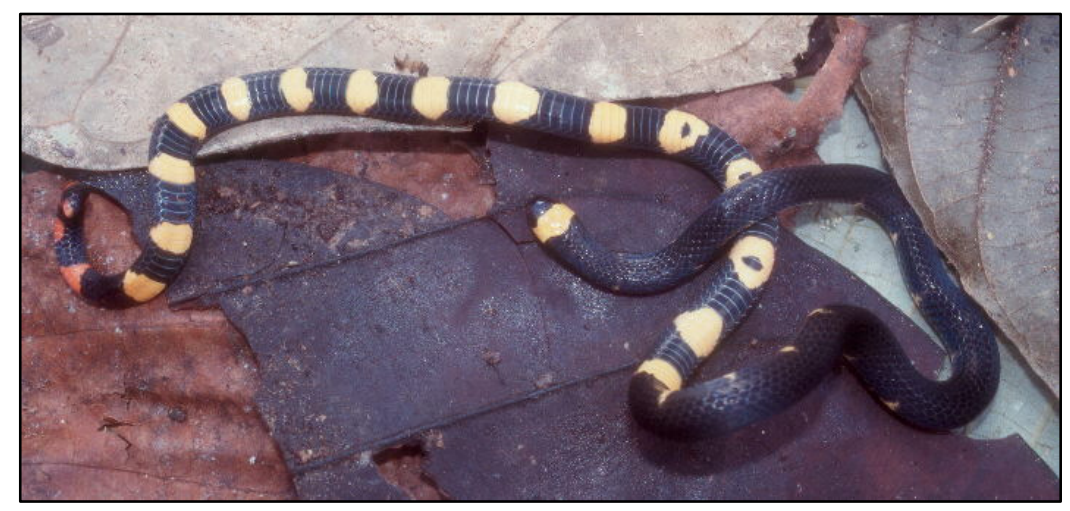

Leptomicrurus scutiventris

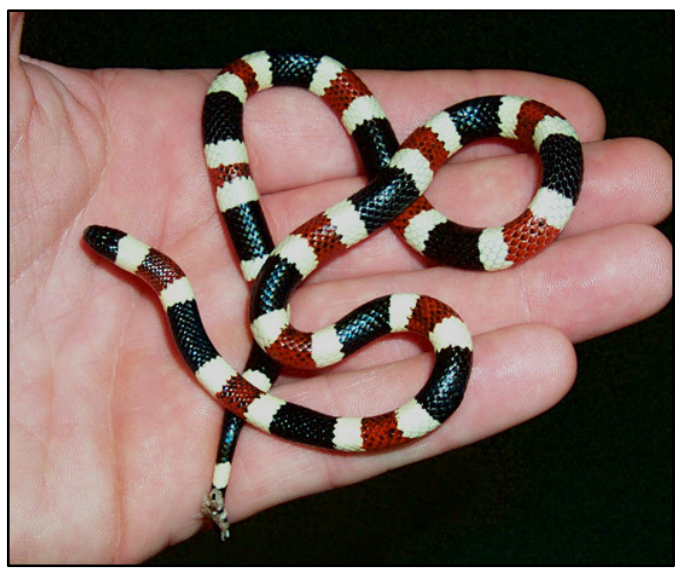

Micruroides euryxantus

Figura 2: Os três gêneros principais encontrados entre as cobras-corais: Micrurus, Leptomicrurus e Micruroides. 


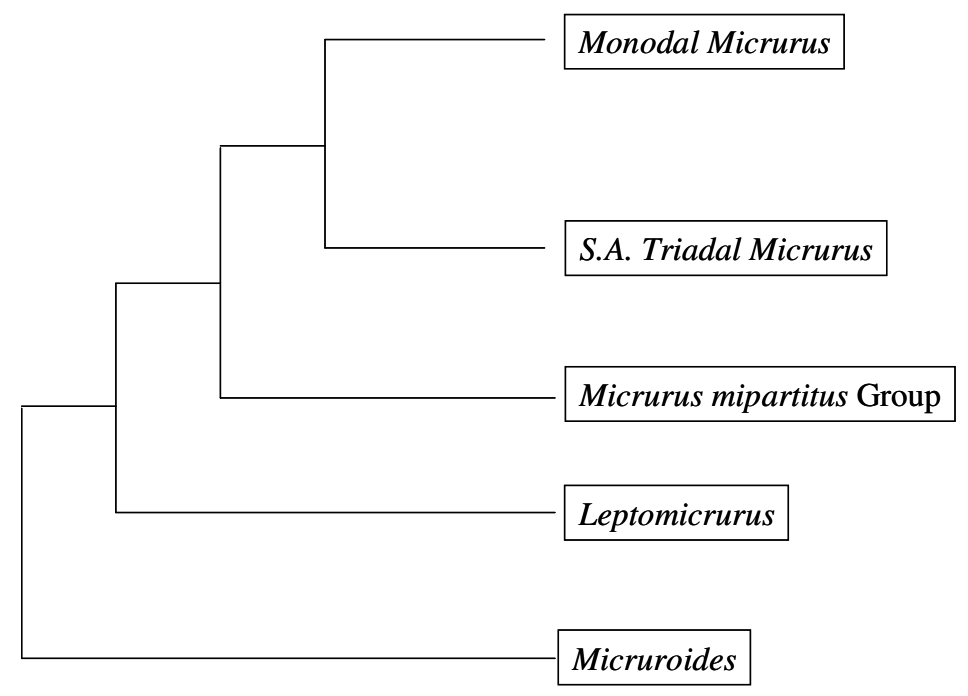

Figura 3: Filogenia de cobras-corais de Roze (1987). S.A. = América do Sul.

\subsection{VENENO DE COBRAS-CORAIS}

\subsubsection{Ações do veneno}

Os dados clínicos relacionados a acidentes por corais são escassos e sugerem um grande conjunto de atividades farmacológicas. Os venenos são conhecidos por serem neurotóxicos, miotóxicos, hemorrágicos e causar efeitos cardiovasculares. Apesar da demonstração dessas atividades, somente os efeitos neurotóxicos e miotóxicos são observáveis em acidentes humanos. Além disso, o veneno dessas serpentes possui toxicidade elevada, se comparado a venenos de serpentes da Família Viperidae, e apresenta uma atividade proteolítica baixa, mas variável, entre as espécies e populações naturais (JORGE DA SILVA JR \& BUCARETCHI, 2003).

\subsubsection{Ação Neurotóxica e Miotóxica}

Classicamente, sabe-se que os venenos das serpentes corais possuem neurotoxinas com dois mecanismos de ação (JORGE DA SILVA JR \& BUCARETCHI, 2003):

- Neurotoxicidade pré-sináptica - causada por proteínas com atividade fosfolipásica. Elas atuam nas terminações axônicas e impedem a liberação de acetilcolina $(\mathrm{ACh})$ na fenda sináptica da junção neuromuscular de nervos 
motores, de maneira similar à $\beta$-bungarotoxina do veneno da serpente Bungarus multicinctus.

- Neurotoxicidade pós-sináptica - causada por proteínas com estrutura em três dígitos (3FTx) desprovidas de ação enzimática. Atuam por fixação competitiva nos receptores colinérgicos das membranas pós-sinápticas da junção neuromuscular de nervos motores (ação semelhante à do curare).

A ação miotóxica pode estar relacionada à ação neurotóxica, ou parcialmente mascarada por ela. Experimentalmente, a maioria dos venenos de corais é capaz de provocar mionecrose. Nos envenenamentos em humanos por corais, um quadro de mialgia pode se instalar, mas sem indicativo claro de mionecrose (JORGE DA SILVA JR \& BUCARETCHI, 2003).

$\mathrm{Na}$ mionecrose, o sarcolema é a principal estrutura celular atingida. Uma vez que o sarcolema é afetado, um influxo de $\mathrm{Ca}^{2+}$ ocorre. Com a elevação do $\mathrm{Ca}^{2+}$ citosólico, há a hipercontração dos microfilamentos, danos mitocondriais e ativação de fosfolipases dependentes do $\mathrm{Ca}^{2+}$. A presença de vesículas citoplasmáticas e alterações mitocondriais são indicadoras da degradação de fosfolipídeos por fosfolipases ativadas pelo $\mathrm{Ca}^{2+}$. A ação mionecrótica experimental também foi evidenciada no veneno de várias espécies de Micrurus do Brasil (GUTIERREZ et al., 1992).

\subsubsection{Ação Hemorrágica}

Os efeitos hemorrágicos foram, inicialmente, demonstrados experimentalmente (MoussatchÉ et al., 1976), mas nunca evidenciados em acidentes humanos. A presença de proporções diferentes e a diversidade de proteases nos venenos já estudados também sugerem uma ação presa-específica. Venenos de M. brasiliensis, M. frontalis e $M$. lemniscatus causam hemorragia visceral, pulmonar e subendocárdica em ratos. Uma fração (fosfolipase A2) do veneno de $M$. frontalis de ação hemorrágica foi isolada e parcialmente caracterizada (JORGE DA SILVA JR \& BUCARETCHI, 2003).

\subsubsection{Ação Cardiovascular}

Efeitos hipotensivos foram descritos, experimentalmente, com o veneno de $M$. fulvius e, mais recentemente, com o veneno de M. frontalis (FRANCIS et al., 1993). 
Os estudos bioquímicos dos venenos são escassos devido à grande dificuldade de capturar e manter em cativeiro essas serpentes e à pequena quantidade de veneno obtida na extração. Estudos comparativos iniciais foram realizados com soroneutralização cruzada. Quando se reage o veneno das principais corais brasileiras (M. corallinus, M. frontalis, M. spixii e M. ibibiboba) com o soro anti-M. corallinus, nota-se que ele é capaz de neutralizar o efeito letal da $M$. corallinus, mas não o das outras três serpentes. Por outro lado, quando reagidos com o soro anti-M. frontalis, este é capaz de neutralizar os efeitos letais do veneno da $M$. frontalis, $M$. spixii e $M$. ibiboboca, mas não o veneno da M. corallinus (HIGASHI et al., 1995). Isso é evidência de que o mecanismo da ação tóxica do veneno da $M$. corallinus é causado por componentes distintos dos presentes no veneno de outras corais, como a M. frontalis (Prieto da Silva et al., 2001a e Prieto DA Silva, 2001b).

Mais recentemente, estudos comparativos enzimáticos, cromatográficos, mionecróticos e imunoquímicos foram realizados com o veneno de várias espécies de serpentes corais do Brasil para esclarecer algumas das ações de seu veneno e determinar padrões de variabilidade intra e interespecífica (AIRD \& JORGE DA SILVA, 1991). Frações neurotóxicas e hemorrágicas também já foram isoladas do veneno de $M$. surinamensis e M. frontalis.

\subsubsection{Componentes do veneno}

Os venenos são misturas biológicas complexas que as serpentes utilizam no ato de imobilizar e matar presas para se alimentar. Os venenos podem ser transparentes ou ter variações de coloração amarela, dependendo da quantidade de L-aminoácido oxidase presente neles, que possui riboflavina (de cor amarelada) como grupo prostético. Os venenos contêm cerca de $25 \%$ de sólidos totais, dos quais cerca de 70 a $90 \%$ são proteínas e polipeptídeos de relativo alto peso molecular. O restante (10-30\%) corresponde a substâncias de baixo peso molecular como carboidratos, aminoácidos, pequenos peptídeos, aminas, nucleotídeos, compostos inorgânicos e íons (JORGE DA SILVA JR \& BUCARETCHI, 2003).

O veneno de cobras-corais contém um número de substâncias enzimáticas e nãoenzimáticas que parece estar presente em grande quantidade em todas as espécies. Ocorre, também, a presença de variação individual e geográfica dentre espécies diferentes do gênero. Sabe-se que os venenos de espécies brasileiras diferentes variam bastante, mas todos apresentam atividade fosfolipásica (AIRD \& JORGE DA SILVA, 1991). 
As enzimas presentes $(13-150 \mathrm{kDa})$ incluem fosfolipases A2, responsáveis pela catálise da hidrólise lipídica. Outras enzimas encontradas na maioria das cobras-corais são a hialuronidase, que atua como outro fator espalhador na destruição de certas barreiras estruturais dos tecidos, e o L-aminoácido oxidase, que tem ação catalítica amplamente distribuída. Algumas hidrolases, tais como fosfodiesterase e anticolinesterase, foram reportadas no veneno de $M$. fulvius e parecem estar presente em venenos de outras espécies (KochOLATY et al., 1971). Dentre as substâncias não-enzimáticas (5-10kDa), estão as neurotoxinas pós-sinápticas, cardiotoxinas (CTX), inibidores de protease, dendrotoxinas (inibidores de serinoproteases do tipo Kunitz), inibidores de acetilcolinesterase e neurotrofinas (NGF) (YEE et al., 2004).

As fosfolipases A2 (PLA2, E.C. 3.1.1.4) são mediadores celulares e estão envolvidas em várias respostas, tais como inflamação, hemólise, inibição da agregação plaquetária e outras. Elas estão presentes nos venenos da maioria das serpentes das Família Viperidae, Elapidae e Hydrophiidae (MÉNEZ et al., 1992). As PLA2 são formadas, principalmente, por cinco $\alpha$-hélices e duas folhas- $\beta$ pregueadas curtas (ARNI \& WARD, 1996). Nem sempre a atividade tóxica das PLA2 está relacionada com atividade enzimática, já que algumas das toxinas mais potentes desta classe não apresentam nenhuma atividade enzimática, possivelmente por ter o aminoácido aspartato da posição 49 (sítio de ligação ao $\mathrm{Ca} 2+$ ) substituído por resíduos de carga positiva, como a lisina (MoRA et al., 2005).

As 3FTx (three finger toxins) não possuem atividade enzimática e contêm de sessenta a 74 aminoácidos. Essas toxinas podem ter suas seqüências facilmente alinhadas por oito cisteínas muito conservadas (STRYDOM, 1977), que formam um núcleo globular da proteína e de onde emergem três alças formadas por cinco folhas- $\beta$ pregueadas antiparalelas, duas folhas antiparalelas formadas pela primeira alça, e três folhas antiparalelas formadas pela segunda alça e parte da terceira alça. (ENDO \& TAMIYA, 1991). Por essa razão são chamadas de toxinas com forma de três dígitos ("three finger shaped toxins"). Nenhuma estrutura em $\alpha$-hélice é encontrada nessas moléculas. A forma é discoidal achatada e apresenta um lado côncavo e um lado convexo. Tem baixa massa molecular, entre 6 a $14 \mathrm{kDa}$, e ponto isoelétrico típico entre pH 8 e 10. São extremamente resistentes às variações físicas ambientais. Devido ao seu pequeno tamanho, são facilmente absorvidas e se distribuem rapidamente nos tecidos da presa (PRIETO DA SILVA, 2001b). Também chamadas de $\alpha$-neurotoxinas ou toxinas 
curaremiméticas, elas são capazes de bloquear a transmissão nervosa ao competir pelo receptor nicotínico de acetilcolina $(\mathrm{nAChR})$ localizado na membrana pós-sináptica dos músculos esqueléticos e neuronais (VITAL BRAZIL, 1980).

Há proteínas fisiológicas em mamíferos que não são toxinas, mas apresentam semelhanças estruturais com as 3FTx (TSETLIN, 1999). Em mamíferos, essas proteínas pertencem a dois grupos de proteínas ancoradas à célula via glicofosfatidilinositol (GPI): proteínas Ly-6 e o receptor de membrana CD59. Essas duas proteínas são monoméricas. Um terceiro grupo de proteínas, também ancoradas a GPI, porém maior e com pelo menos três domínios em três dígitos, é o uPAR, receptor para o ativador de plasminogênio do tipo uroquinase.

Citotoxinas são proteínas básicas, desprovidas de ação enzimática e capazes de causar hemólise, citólise, despolarização de membranas musculares e cardiotoxicidade específica. Muitos autores consideram sinônimas as citotoxinas e as cardiotoxinas, em vista das suas semelhanças estruturais. As cardiotoxinas são componentes que se ligam a receptores de membrana das fibras musculares cardíacas e produzem despolarização da fibra e paralisia irreversível, com parada cardíaca. A única serpente da América cujo veneno contém cardiotoxinas, pelos relatos até hoje, é a M. fulvius (EUA e México), mas é muito provável que elas estejam presentes nos venenos de outras Micrurus, como demonstrado por JORGE DA SILVA JR et al. (1991).

\subsubsection{Envenenamento por cobras-corais}

Envenenamentos humanos causados por cobras-corais são relativamente raros devido a seus hábitos (semifossoriais) e comportamento não agressivo. Apesar da baixa incidência, os acidentes causados por serpentes corais são graves.

A característica principal do envenenamento por Micrurus é o choque neurotóxico (BRAZIL \& BRAZIL FiLho, 1933). Sabe-se que a ação dos venenos de $M$. corallinus e $M$. frontalis, as duas espécies usadas na produção do soro antielapídico, é bastante distinta uma da outra (VITAL BRAZIL, 1987). Ambos atuam na junção neuromuscular, causa evidente de sua ação letal. No entanto, o que diferencia basicamente esses dois venenos é a atuação sobre a sinapse, na qual a M. frontalis apresenta apenas ação pós-sináptica, e a $M$. corallinus, ação pré-sináptica com aumento espontâneo da liberação de acetilcolina associado ao bloqueio pós-sináptico da transmissão elétrica entre o nervo e o músculo (VITAL BRAZIL \& FONTANA, 1983/84). VITAL BRAZIL \& FONTANA (1983/84) consideram que, embora exista um bloqueio 
evidente do receptor nicotínico por $\alpha$-neurotoxinas, a ação principal do veneno de $M$. corallinus é pré-sináptica.

Como os acidentes elapídicos no Brasil, causados pelas serpentes pertencentes ao gênero Micrurus ou cobras-corais, é pouco freqüente, é possível compreender um número reduzido de investigações para estudar as repercussões clínicas do envenenamento causado por esse gênero de serpentes.

Sabe-se que os venenos das cobras-corais são extremamente ativos e de alta toxicidade, mas a maior parte dos pacientes que procuram os serviços médicos após acidentes causados por esssa serpentes apresenta manifestações clínicas de envenenamento discretas, ou mesmo ausência delas, sendo raros os acidentes graves com manifestações paralíticas. Possivelmente, essas observações clínicas estão relacionadas com os aspectos biológicos dessas serpentes na natureza. As cobras-corais são, de maneira geral, animais de pequeno porte e de baixa agressividade, além de ter presas inoculadoras anteriores e pequenas, o que dificultaria a injeção da peçonha.

Com certa freqüência, o individuo é picado na região digital ao manusear a serpente de forma inadequada e imprudente. As manifestações clínicas locais costumam ser discretas. O edema, quando presente, costuma ser leve e, geralmente, se associa ao uso prévio de torniquetes. Não se observam equimoses ou hemorragias locais, embora tenha sido demonstrado recentemente que a peçonha da espécie $M$. avery, da região amazônica, apresenta atividade hemorrágica em camundongos (BARRos et al., 1994). A maioria dos pacientes menciona dor no local da picada, de intensidade variável, com tendência à progressão proximal e geralmente acompanhada de parestesia.

As manifestações sistêmicas são caracterizadas pela atividade neurotóxica pré e pós-sináptica do veneno na junção neuromuscular, o que desencadeia bloqueio da liberação de ACh e competição das neurotoxinas com os receptores colinérgicos da placa terminal da junção neuromuscular e o conseqüente aparecimento de síndrome miastênica aguda. O início das manifestações paralíticas é muito variável: podem surgir de minutos a horas após a picada. De maneira geral, essas manifestações se iniciam depois de várias horas após o acidente. Porém, uma vez iniciadas, tendem a progredir e a se agravar caso não se institua o tratamento adequado. As seguintes manifestações paralíticas têm sido relatadas (JORGE DA SILVA JR \& BUCARETCHI, 2003):

- ptose palpebral;

- dificuldade de acomodação visual;

- oftalmoplegia e anisocoria; 
- dificuldade para deglutição e mastigação;

- dificuldade para se manter na posição ereta ou para se levantar;

- dispnéia restritiva e obstrutiva, respectivamente por paralisia da musculatura torácica intercostal e por acúmulo de secreções, que evoluem para paralisia diafragmática.

\subsubsection{Epidemiologia}

A apresentação dos dados sobre acidentes por animais peçonhentos no Brasil é baseada na notificação à CNCZAP (Coordenação Nacional de Controle de Zoonoses e Animais Peçonhentos) de 81.611 acidentes no período de janeiro de 1990 a dezembro de 1993, o que representou uma média de 20 mil casos/ano para o país. A maioria dos acidentes foi registrada nas regiões Sudeste e Sul, as mais populosas e com melhor organização de serviços de saúde e sistemas de informação. Os coeficientes anuais de incidência para o Brasil estiveram em torno de 13 acidentes/100 mil habitantes, distribuídos desigualmente nas diferentes macrorregiões (Tabela 1).

No mesmo período, a distribuição dos acidentes de acordo com o gênero da serpente indica um predomínio absoluto do envenenamento botrópico, seguidos dos acidentes crotálico, laquético e elapídico (Tabela 2).

Tabela 1: Coeficientes de incidência anual (por 100 mil habitantes) dos acidentes ofídicos por região fisiográfica. Brasil, 1990 a 1993. Dados fornecidos pelo CNCZAP.

\begin{tabular}{lcccc}
\hline \multirow{2}{*}{ Região } & \multicolumn{4}{c}{ Coeficientes de incidência $(\mathbf{x}$ 100 mil) habitantes } \\
\cline { 2 - 5 } & $\mathbf{1 9 9 0}$ & $\mathbf{1 9 9 1}$ & $\mathbf{1 9 9 2}$ & $\mathbf{1 9 9 3}$ \\
\hline Norte & 24.4 & 23.2 & 23.8 & 25.9 \\
Nordeste & 6.8 & 6.7 & 6.2 & 7.6 \\
Centro-Oeste & 34.7 & 28.4 & 38 & 32.1 \\
Sudeste & 13.1 & 13.2 & 12.9 & 12.3 \\
Sul & 15.3 & 15.1 & 17.5 & 16.8 \\
\hline Brasil & $\mathbf{1 3 . 8}$ & $\mathbf{1 3 . 3}$ & $\mathbf{1 4 . 1}$ & $\mathbf{1 3 . 9}$ \\
\hline
\end{tabular}


Tabela 2: Diagnóstico dos acidentes ofídicos segundo gênero no Brasil, 1990 a 1993. Dados fornecidos pelo CNCZAP.

\begin{tabular}{lll}
\hline Diagnóstico & No de Acidentes & $\%$ \\
\hline Bothrops & 59.619 & 73.1 \\
Crotalus & 5.072 & 6.2 \\
Lachesis & 939 & 1.1 \\
Micrurus & 281 & 0.3 \\
Não informados & 13.339 & 16.3 \\
Não peçonhentos & 2.361 & 2.9 \\
\hline
\end{tabular}

Os casos de envenenamento de cobras-corais no Brasil são devidos, principalmente, à $M$. corallinus e à $M$. frontalis, que ocupam áreas altamente povoadas na região Central, Sul e Sudeste do Brasil. Comparado com os viperídeos, o número de acidentes provocados pela cobra-coral não é muito grande, já que ela é pouco agressiva e ataca somente quando ameaçada (CAMPBELL \& LAMAR, 2004). Porém, quando o acidente ocorre, os sintomas costumam ser bastante graves e podem levar à morte por asfixia após cinco ou seis horas (VITAL BRAZIL, 1980). No Brasil, o número de acidentes elapídicos nos últimos cinco anos tem permanecido ao redor de $1 \%$ ao ano, como pode ser observado na Tabela 3 abaixo.

Tabela 3: Comparação entre o número de acidentes elapídicos e o número de acidentes ofídicos ocorridos entre 2001 e 2005.

\begin{tabular}{|c|c|c|}
\hline Ano & Acidentes elapídicos & Total de acidentes ofídicos \\
\hline 2001 & 114 & 19342 \\
\hline 2002 & 127 & 24682 \\
\hline 2003 & 143 & 27196 \\
\hline 2004 & 123 & 26952 \\
\hline 2005 & 143 & 27831 \\
\hline
\end{tabular}

Fonte: Sinan-Animais Peçonhentos/SVS/MS, dados atualizados até 24/04/2006. 


\subsection{SOROS ANTIVENENO DE SERPENTES}

\subsubsection{Histórico}

Atualmente, a produção de soros antitoxinas animais ainda é baseada nos métodos originalmente descritos por Vital Brazil (CARDOSO et al., 2003), que, por meio de imunização em cavalos com veneno de serpentes, pôde demonstrar as relações de especificidade entre os soros imunológicos e os venenos que lhes deram origem. A partir desse momento, a soroterapia foi então introduzida como tratamento para acidentes ofídicos no Brasil. O soro antiaracnídico e o soro antiescorpiônico também surgiram posteriormente, produzidos juntamente com o soro antiofídico por algumas instituições no país, como o Instituto Butantan, em São Paulo, o Instituto Vital Brazil, no Rio de Janeiro, a Fundação Ezequiel Dias (Funed), em Belo Horizonte e o Centro de Produção e Pesquisa em Imunobiológicos (CPPI), em Curitiba (CARDOso et al., 2003).

Do ponto de vista prático, é necessário distinguir a produção de soro para fins analíticos daquela para fins terapêuticos. Na obtenção de soros policlonais para análise, o veneno é injetado em animais de pequeno porte para se obter um soro imunoreativo que permita seu uso em procedimentos imunoquímicos. Entretanto, a produção de soros voltados à soroterapia é baseada na imunização de animais de grande porte (cavalos, caprinos etc.) com venenos de uma ou mais espécies de animais peçonhentos de importância médica, o que por si só apresenta uma diferença marcante quanto à escala de trabalho. Além disso, por se tratar de um produto para uso interno humano, deve atender a inúmeras exigências de controle de eficiência e qualidade.

Para que um soro seja eficiente na neutralização dos efeitos tóxicos de veneno animal, é necessário que ele contenha anticorpos dirigidos contra as principais toxinas responsáveis por sua ação sistêmica e local (WARREL, 1997). Dessa forma, a escolha da fonte dos antígenos utilizados na imunização dos animais é um fator primordial para obtenção dos produtos ativos. Devido à grande variabilidade da glândula de veneno de serpentes, às diferenças entre as espécies de um mesmo gênero ou ainda entre indivíduos de uma mesma espécie, vários soros devem ser produzidos com finalidade específica para cada tipo de acidente (WARREL, 1997).

Dadas as características estruturais de cada toxina, algumas delas são mais eficientes que outras em induzir resposta imune (CARDOSO et al., 2003). A imunização de animais com misturas complexas de antígenos pode, então, levar à produção de 
anticorpos predominantemente contra algumas toxinas e deixar que outras, menos imunogênicas, não apresentem anticorpos específicos. Outro fenômeno que pode ocorrer é a redução da resposta imune, devido à presença de proteínas imunosupressoras, como as descritas nos venenos de Crotalus durissus terrificus (CARDOSO et al., 1997).

Por outro lado, a mistura de soros monoespecíficos leva, necessariamente, à diluição do conteúdo total de anticorpos contra o veneno de cada espécie, e por isso sua eficiência tende a ser reduzida. Outro aspecto relevante na imunização tradicional é a forma de preparação dos antígenos. O ideal seria a administração de venenos ativos, por ser mais confiável que o uso de componentes detoxificados, porém os efeitos deletérios do veneno podem comprometer a saúde do animal. Assim, uma combinação de doses com frações menos tóxicas seguidas de doses reforço com o veneno total pode ser mais eficiente (HIGASHI et al., 1989).

Apesar das dificuldades de obtenção desses soros, somada às desvantagens citadas acima, seu uso é considerado o tratamento mais efetivo na neutralização de toxinas com ação sistêmica presente na glândula de veneno de serpentes (RAWEERITH et al., 2005).

Nos últimos anos, a obtenção de soros hiperimunes contra venenos para fins analíticos vem ganhando outro rumo, já que os avanços alcançados pela biologia molecular têm tornado possível a obtenção não apenas de toxinas animais recombinantes, mas também do uso dessas toxinas e de seus cDNAs para fins imunológicos, como veremos mais adiante.

\subsubsection{A produção do soro antielapídico}

Do pouco que é sabido sobre veneno da $M$. corallinus, é possível dizer que ele é bastante específico, mesmo comparado a outras espécies do gênero. Sabe-se que o principal tipo de toxina do veneno da $M$. corallinus é a neurotoxina pré-sináptica, que inibe a liberação de acetilcolina pelas terminações nervosas motoras, enquanto as principais toxinas do veneno da $M$. lemniscatus e $M$. frontalis são neurotoxinas póssinápticas, curaremiméticas (VITAL BRAZIL, 1987). Tanto as pré-sinápticas como as póssinápticas podem também estar presentes em uma mesma espécie. Por essa razão, o soro antielapídico monoespecífico pode não surtir o efeito desejado se a vítima for picada por uma $M$. corallinus. É por essa razão que o soro antielapídico produzido deve englobar esses dois tipos diferentes de toxinas presentes no veneno das cobras-corais 
encontradas no Brasil. Dessa forma, este soro antielapídico apresenta anticorpos produzidos a partir de imunização em cavalos com veneno de $M$. corallinus e $M$. frontalis na proporção de 1:1, de modo a conter tanto o soro de $M$. corallinus como o de M. frontalis.

A M. corallinus possui dieta ofiófaga, hábito fossorial e o padrão mimético encontrado em várias outras serpentes. Essas características dão indício da dificuldade de se obter e manter esses animais em cativeiro. Somada à dificuldade de manutenção, o tamanho reduzido de suas glândulas e, conseqüentemente, a baixa produção de veneno tem gerado uma problemática na produção de soro antielapídico no Instituto Butantan.

O Instituto Butantan acaba utilizando a quase integralidade do veneno conseguido para a obtenção de soro antielapídico e pouco ou nada dele acaba restando para estudos bioquímicos (Ho et al., 1995). Na verdade, mesmo a quantidade de veneno disponibilizada para a obtenção de soro não atende ao que seria o ideal para suprir a demanda de produção que cobrisse todo o território nacional. Mesmo que o número de acidentes seja pequeno se comparado ao de outros gêneros, a ampla dispersão geográfica do gênero Micrurus e a gravidade dos acidentes exigem que o soro seja distribuído por todo o país, o que aumenta a demanda de produção.

Tabela 4: Quadro geral da disponibilidade dos animais entregues ao Instituto Butantan para cada gênero de serpentes, a quantidade de veneno e a longevidade em cativeiro (valores aproximados).

\begin{tabular}{|c|c|c|c|}
\hline Gênero & $\begin{array}{c}\text { No de animais } \\
\text { entregues por ano }\end{array}$ & $\begin{array}{c}\text { Quantidade de veneno por } \\
\text { extração }(\mu \mathrm{L} / \text { extração) }\end{array}$ & $\begin{array}{c}\text { Longevidade em } \\
\text { cativeiro (anos) }\end{array}$ \\
\hline Bothrops & 2200 & $400-900$ & 5 \\
\hline Crotalus & 1500 & 300 & 2 \\
\hline Lachesis & 2 & $800-1000$ & 1 \\
\hline Micrurus & 200 & $5-20$ & 5 \\
\hline
\end{tabular}

Fonte: Laboratório de Herpetologia do Instituto Butantan, dados fornecidos em comunicação pessoal em 2005 (valores aproximados). 


\subsection{IMUNIZAÇÃO GENÉTICA OU VACINA DE DNA}

Nos últimos anos, a obtenção de soros hiperimunes contra venenos para fins analíticos vem tomando outro rumo, já que os avanços alcançados pela biologia molecular tornaram possível a obtenção não apenas de toxinas animais recombinantes, mas também o uso dessas toxinas e de seus cDNAs para fins imunológicos. Elas agora podem ser usadas para a imunização com toxinas recombinantes ou apenas com fragmentos com epítopos específicos (TANJONI et al., 2003), e ainda há a possibilidade de imunização genética (vacinas de DNA) (HARRISON et al., 2000; HARRISON, 2004; HASSETt \& WhitTon, 1996; LiU, 2003; WAgSTAFF \& HarRison, 2006). Esse último campo é recente e pode representar uma alternativa bastante promissora para resolver situações nas quais a imunização tradicional pode não ser possível devido à falta de antígenos.

A imunização genética teve início a partir de observações em 1992 de que plasmídeos poderiam ser utilizados para expressar DNA exógeno em células animais e estimular a resposta imunológica (TANG et al., 1992). O trabalho de HARRISON et al. (2000) demonstram que ratos imunizados com DNA que codifica o domínio carboxiterminal JD9 da jararagina, a mais importante toxina da jararaca, por meio do método de biobalística (Gene-Gun), obtiveram altos títulos de anticorpos IgG. Esse foi o primeiro estudo em que foram aplicados métodos baseados em injeção de DNA para preparações de antiveneno. $\mathrm{O}$ método pode representar uma nova abordagem imunológica mais específica e com menos efeitos colaterais do que os sistemas convencionais de produção de antiveneno. HARRISON (2004) conseguiu produzir altos títulos de anticorpos com potencial para melhoria no tratamento sistêmico de picadas de serpentes da família Viperidae. Recentemente, WAGSTAFF \& HARRISON (2006) imunizaram camundongos com DNA quimérico sintético contendo sete epítopos de maior significância dentro do grupo de metaloproteinases (SVMP) expressas em glândulas de veneno de Echis ocellatus e Cerastes cerastes. Estes epitopos foram escolhidos bioinformaticamente a partir do transcriptoma dessa espécie, ou seja, após a identificação de alguns milhares de cDNAs abundantes de suas glândulas de veneno. Como resultado, conseguiram excelente proteção contra esse veneno e contra o de espécies correlatas.

Alguns trabalhos de imunização por DNA foram muito bem-sucedidos, como pode ser verificado nos trabalhos citados acima, e pensar em soro antiveneno a partir de 
vacina de DNA é inovador. No entanto, o maior desafio a ser vencido ainda se refere ao estabelecimento de estudos mais conclusivos sobre as vantagens de se substituir a forma tradicional de produção de soros ou de complementar a demanda de soros antivenenos com a fabricação de soros por tecnologias recombinantes.

\subsection{TRANSCRIPTOMAS DE GLÂNDULAS DE VENENOS}

Uma abordagem muito utilizada hoje a fim de obter um perfil geral de toxinas presentes na glândula de veneno tem sido a análise transcriptômica. A geração de ESTs (Expressed Sequence Tags) é um método bastante interessante, já que se baseia no seqüenciamento aleatório de clones de uma biblioteca de cDNA e fornece uma amostra estatisticamente representativa da diversidade da expressão gênica naquele sistema (LEE et al., 1995). Em termos qualitativos e quantitativos, é uma forma de se representar os mRNAs expressos no tecido analisado.

Essa técnica parece ser bastante apropriada para o estudo de tecidos raros ou de caracterização bioquímica difícil - caso das serpentes do gênero Micrurus - pois permite a análise indireta da composição de proteínas a partir do seqüenciamento parcial de cDNAs. Uma grande quantidade de clones representados em uma biblioteca pode ser obtida por meio de pequenas quantidades de RNA e perpetuada sem a necessidade de muito material biológico (ADAMS et al., 1991). Esse sistema de análise de bibliotecas de cDNA tem a vantagem de ser mais prático do que o seqüenciamento total do cDNA, pois utiliza-se de primers universais que permitem a leitura das extremidades 3' e 5' dos cDNAs, suficiente para a sua identificação.

$\mathrm{Na}$ área toxinológica, as ESTs vêm tornando possível a identificação das toxinas já bioquimicamente conhecidas no veneno de uma serpente ou a descrição de novas toxinas após análise comparativa com bancos de sequiências de DNA e proteínas. Por ser uma abordagem mais genérica e não focada em componentes específicos, muitas vezes permite a identificação de novas toxinas que, por abordagens objetivas e direcionadas, não poderiam ser descobertas (JUNQUEIRA DE AZEVEDO \& Ho, 2002). Além disso, com o transcriptoma não são descritas apenas seqüências, mas ainda um perfil da composição e diversidade das proteínas presentes no veneno da serpente pode ser levantado de forma simples e abrangente, visto que o seqüenciamento aleatório de clones de uma biblioteca primária de cDNA fornece amostra representativa da diversidade da expressão gênica naquele sistema (LEE et al., 1995). 
Em 2002, foi realizado em nosso laboratório o primeiro estudo da diversidade dos componentes presentes no veneno de uma serpente através da geração de ESTs (JunqueIRA DE AZEVEdo \& Ho, 2002 e JunqueIRA DE AZEVEDO, 2003a). Durante a geração de ESTs da glândula de veneno de $B$. insularis, uma serpente da família Viperidae, e sua análise posterior e identificação em banco de dados, puderam ser identificados alguns cDNAs nunca antes descritos em glândulas de venenos. Esse trabalho trouxe um perfil do transcriptoma da glândula de veneno da B. insularis, com a ocorrência, abundância e seqüência completa de diferentes metaloproteinases (SVMP), serinoproteinases, peptídeos potenciadores de bradicinina, entre outras toxinas. Além disso, foi possível identificar a seqüência de um suposto fator de crescimento do endotélio vascular (VEGF), que posteriormente demonstramos ser de fato uma nova toxina, totalmente diferente de todas já encontradas em venenos (JUNQUEIRA DE AzEVEDo et al., 2001 e KOMORI et al., 1999). Pudemos identificar ainda a seqüência do cDNA de uma suposta proteína de ligação com $\mathrm{Ca}^{2+}$ com quatro motivos EF-hand, que foi denominada calglandulina (JUNQUEIRA DE AZEVEDO et al., 2003b). Uma forma ortóloga dessa proteína foi detectada em humanos (CHEN et al., 2004) e chamada de calglandulin-like, por ser a calglandulina de B. insularis a única referência dessa nova proteína humana.

Um outro relato de transcriptoma de serpentes foi publicado por KASHIMA et al. (2004). Foram seqüenciados 549 clones de B. jararacussu que se agruparam em 197 clusters. Uma comparação com o banco de dados identificou PLA2, incluindo as formas Lys49 e Asp49 e outras toxinas. Nenhum precursor dos BPPs (Peptídeo Potenciador de Bradicinina) foi encontrado, o que mostra diferenças significativas entre exemplares de espécies distintas. FRANCISCHETTI et al. (2004) também publicaram um trabalho similar sobre cDNAs expressos de Bitis gabonica.

Ultimamente, vários transcriptomas de glândulas de veneno de serpentes de espécies da família Viperidae têm sido relatados por nosso e outros grupos. QINGHUA et al. (2006) identificou toxinas relacionadas à coagulopatia por meio do estudo do transcriptoma realizado de glândulas de veneno de Agkistrodon acutus. O transcriptoma de Echis ocellatus foi realizado pelo grupo de WAGSTAFF \& HARRISON (2006). No nosso grupo, analisamos uma biblioteca da serpente Lachesis muta (JUNQUEIRA DE AZEVEDo et al., 2006), e, recentemente, foi publicado um artigo científico sobre o transcriptoma de espécies da Família Colubridae (CHING et al., 2006). Em nosso grupo, realizamos ainda estudos de transcriptomas de outros organismos produtores de 
venenos, como a aranha Loxosceles laeta (FERNANDES-PEDROSA et al., 2002), a sanguessuga Haementeria depressa (FARIA et al., 2005) ou o carrapato Amblyoma cajennensis (BATISTA et al., 2008). É importante enfatizar que não há relatos de trabalhos sobre transcriptoma dentre a família Elapidae.

No caso de cobras-corais do gênero Micrurus, levando em conta seu hábito fossorial e alimentar, além da dificuldade de se conseguir quantidade adequada de veneno para estudos bioquímicos, a obtenção de um banco de ESTs pode ser extremamente útil por permitir o primeiro estudo sistemático da composição molecular de suas toxinas. Além de representar uma contribuição para o conhecimento biológico de seu veneno, também permitirá a seleção de candidatos antigênicos para o desenvolvimento de um soro antielapídico alternativo. Na verdade, é de grande interesse do Instituto Butantan, junto ao Centro de Biotecnologia, a déia do desenvolvimento de metodologias alternativas que permitam a auto-suficiência do Instituto para atender a demanda de produção de soros antielapídeos para o país. Entendemos que o transcriptoma, seguido de uma análise da viabilidade da obtenção de formas recombinantes de toxinas representativas selecionadas, ou sua imunização genética, sejam etapas iniciais imprescindíveis para se pensar em um processo alternativo de imunização. 


\section{OBJETIVOS}

- Geração de Expressed Sequences Tags (ESTs) das glândulas de veneno de Micrurus corallinus (cobra-coral)

- Montagem de clusters, anotação e análise qualitativa e quantitativa da expressão gênica a partir do banco de ESTs

- Escolha de candidatos antigênicos para uma imunização genética preliminar. 


\section{MATERIAL E MÉTODOS}

\subsection{PREPARO DE FAGOS PARA GERAÇÃO DE ESTS}

\subsubsection{Biblioteca de Micrurus corallinus (fago גgt11D)}

Foram utilizadas bibliotecas de M. corallinus obtidas pelo Dr. Paulo Lee Ho, do Centro de Biotecnologia do Instituto Butantan, já validadas em trabalhos anteriores (Ho et al., 1995 e Ho et al., 1997), preparadas a partir do RNA poli(A) extraído de dez espécimes de M. corallinus, como descrito por SOARES (1994). Os cDNAs obtidos foram divididos em duas frações (400 a 600 pb e >600 pb), visto que as neurotoxinas de três dígitos e as PLA2 são codificadas por transcritos menores. Foram ligados a fagos $\lambda g t 11 D$ pré-digeridos com extremidades EcoRI/NotI (Pharmacia).

\subsubsection{Preparação da bactéria E. coli Y1088}

Foi feito um pré-inóculo de colônia de E. coli Y1088 em 5mL de meio NZCYM (SAMBROOK et al., 1989) acrescido de maltose 0,2\%. O inóculo cresceu no mesmo meio de cultura. Após a adição de $\mathrm{MgSO}_{4}$ 0,01M, a densidade óptica (DO) foi acompanhada até cerca de 2,0.

\subsubsection{Montagem das placas para fagos}

Placas "bottom ágar" foram preparadas com o meio NZCYM citado acima, acrescido de ágar. Para o plaqueamento dos fagos, 100 $\mu \mathrm{L}$ de bactéria E. coli Y1088 foram misturados a $100 \mu \mathrm{L}$ de uma diluição dos fagos (descrita a seguir). O material é incubado por vinte minutos a $37^{\circ} \mathrm{C}$ e a mistura foi acrescida ao meio NZCYM com agarose ("top agarose" 0,7\%). O "top agarose" é, então, distribuído sobre a placa "bottom ágar". Após 12-16 horas, as placas estavam preparadas para isolamento das colônias líticas de fagos.

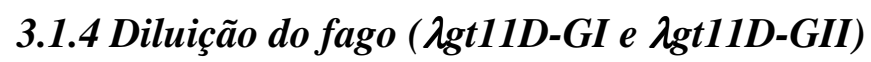

Foram feitas diluições seriadas de 1:10 a 1:107 em meio SM (SAMBROOK et al., 1989) a fim de descobrirmos o melhor valor para o trabalho, ou seja, qual proporção era mais adequada para se observar as colônias líticas devidamente espaçadas. Descoberta a diluição mais apropriada para a detecção das colônias líticas, o fago $\lambda$ gt11D 
(Pharmacia) passou a ser diluído na proporção ótima da placa toda vez que fosse necessário preparar o conteúdo de "top agarose” descrito anteriormente.

\subsubsection{Amplificação do cDNA contido no fago (PCR)}

Cada placa de lise (colônia lítica) foi aspirada por pipeta Pasteur descartável e inserida em um tubo contendo meio SM. Após uma hora de incubação sob agitação em temperatura ambiente, o material genético do fago estava preparado para ser amplificado. Foram utilizados dois tipos de enzima taq polimerase para a amplificação do cDNA contido nos fagos: Taq DNA Polymerase Recombinant, da Invitrogen; e Platinum $囚 T a q$ DNA Polymerase, da Invitrogen. Os primers utilizados foram $\lambda g t 11$ forward (5' GGTGGCGACGACTCCTGGAGCCCG 3') e reverse (5' TTGACACCAGACCAACTGGTAATG 3') que se ligam ao fago $\lambda$ gt $11 D$ correspondente. Por esse método, não foi necessário purificar os fagos nem a extração de seu DNA, pois o material genético do fago se expõe durante o PCR (Polymerase Chain Reaction). O produto de PCR foi purificado para uso posterior no seqüenciamento, segundo três protocolos distintos que avaliamos para escolha do mais eficiente pelo menor custo: 1) por separação em gel de agarose seguida de purificação física em colunas de sílica da banda majoritária, com $G F X^{T M} P C R-D N A$ and Gel Purification Kit, da Amersham Biosciences; 2) por purificação física direta do produto de PCR; ou 3) por tratamento químico do produto de PCR, realizado com enzimas exonuclease I (ExoI) 10U/ $\mu \mathrm{L}$, da Amersham Biosciences, e Shrimp Alcaline Phosphatase (SAP) 1U/ $\mu \mathrm{L}$, da Amersham Biosciences.

A purificação do produto de PCR por tratamento químico foi baseada no protocolo usual utilizado no Centro do Genoma Humano, na Universidade de São Paulo (USP). É feita uma reação com $8 \mu \mathrm{L}$ de produto de PCR, somado a um mix de $0,5 \mu \mathrm{L}$ de ExoI e $1 \mu \mathrm{L}$ de SAP. A amostra é colocada por uma hora a $37^{\circ} \mathrm{C}$ e inativada por 15 minutos a $80^{\circ} \mathrm{C}$.

\subsubsection{Seqüenciamento dos clones}

Com os plasmídeos ou o cDNA do fago isolados, foi feito o seqüenciamento deles. Primeiramente foi feita a reação de seqüenciamento, na qual foram colocados o DNA amplificado (300ng), o primer (3,2pmol), tampão $6 \mu \mathrm{l}$ (Save Money, 200mM Tris$\mathrm{HCl}$ pH 9.0 e $5 \mathrm{mM} \mathrm{MgCl}_{2}$ ) e Big Dye $(2 \mu \mathrm{l})$ (Kit Big Dye, Applied Biosystems). As 
amostras foram precipitadas com isopropanol e ressuspendidas em $20 \mu$ formamida (Applied Biosystems).

Foram produzidas sequiências parciais por meio da utilização do primer $\lambda g t 11 \mathrm{~F}$ para a síntese da cadeia complementar, gerando ESTs 5'. Esse primer se liga ao sítio promotor do fago utilizado, $\lambda g t 11$, que está presente no produto de PCR. A síntese se inicia em apenas um sítio onde o primer se anela ao DNA do vetor e termina quando ocorre a incorporação de um dos nucleotídeos análogos, 2’3’ dideoxinucleotídeos 5 'trifosfatos (ddNTPs), pois a polimerase não consegue continuar a elongação do DNA. A leitura se baseia na separação em polímero de seqüenciamento (POP6) dos diferentes tamanhos dos DNAs sintetizados nas amostras, contendo os quatro dideoxi-nucleotídeos fluorescentes que emitem comprimentos de onda diferentes (Kit Big Dye). Foi utilizado o seqüenciador ABI 3100, da Applied Biosystems, de dezesseis capilares.

\subsubsection{Análise das seqüências expressas}

Para os processos de análise, foi utilizado um conjunto de programas de bioinformática desenvolvido no laboratório (pipeline de submissão), otimizado especialmente para os modelos de sequiências de toxinas com que trabalhamos, pois a enorme quantidade de isoformas e formas parálogas de toxinas requerem parâmetros estringentes de análise. Primeiramente, as sequiências tiveram eliminadas as seqüências do vetor e as regiões de baixa qualidade. Para isso, utiliza-se o programa Phred (HUANG \& MADAN, 1999) e são aceitos somente trechos de seqüência com $75 \%$ de bases com qualidade (valor de phred) igual ou acima de 25, dentro de uma janela de 75 bases. Em seguida, houve a remoção de adaptadores e vetores com o programa CrossMatch. As sequiências menores que $150 \mathrm{pb}$ foram descartadas. Finalmente, as ESTs foram agrupadas em clusters (conjuntos de sequiências contíguas). Por meio do programa CAP3 (LAZO et al., 2001) com parâmetros estringentes e com descarte de clusters com posições ambíguas em bases de alta qualidade.

Com os clusters montados, foi feita uma comparação com o banco de dados, primeiramente por Blastx (nucleotídeos x aminoácidos) e, se necessário, por Blastn (nucleotídeos x nucleotídeos), para uma identificação dos clusters. Para uma melhor interpretação dessas identificações foi criada uma tabela de anotações, com todos os dados apresentados no banco (e-value, porcentagem de similaridade, overlap etc.), o que permite análises quantitativas a respeito da proporção de expressão de cada cluster. 


\subsection{CLONAGEM DOS CANDIDATOS ANTIGÊNICOS PARA IMUNIZAÇÃO GENÉTICA}

(VACINA DE DNA)

\subsubsection{Os candidatos antigênicos}

Foram cinco os cDNAs candidatos selecionados a partir da análise do banco transcriptômico de Micrurus corallinus, quatro deles representantes das 3FTx e um representante de PLA2. Estes cinco candidatos foram selecionados por serem as toxinas mais abundantes na glândula de veneno dessa serpente e por outros critérios descritos no item 4.2.1. Os representantes desses cinco candidatos antigênicos foram nomeados Antígeno 1 (Atg1) a Antígeno 5 (Atg5) (Tabela 5).

Tabela 5: Apresentação dos diferentes candidatos, clusters, clones e tamanhos (pb) respectivos. Para cada clone foi atribuída uma numeração para facilitar sua denominação.

\begin{tabular}{|c|c|c|c|c|}
\hline Candidato & Cluster & $\begin{array}{c}\text { Clones utilizados } \\
\text { da biblioteca }\end{array}$ & $\begin{array}{c}\text { Clones da } \\
\text { subclonagem }\end{array}$ & $\begin{array}{c}\text { Tamanho } \\
\text { da ORF } \\
(\mathbf{p b})\end{array}$ \\
\hline Atg1 & MCOR0604C & $\begin{array}{c}\text { MCAL01H08 } \\
\text { MCAL09C06 }\end{array}$ & MCAL01H08.5 & 258 \\
\hline Atg2 & MCOR0599C & $\begin{array}{l}\text { MCAL07D03 } \\
\text { MCAL07H04 }\end{array}$ & MCAL07D03.2 & 234 \\
\hline Atg3 & MCOR0039C & $\begin{array}{l}\text { MCAH05B08 } \\
\text { MCAL06A11 }\end{array}$ & MCAH05B08.1 & 246 \\
\hline Atg4 & MCOR0100C & $\begin{array}{l}\text { MCAL07E03 } \\
\text { MCAL09G04 }\end{array}$ & MCAL07E03.5 & 246 \\
\hline Atg5 & MCOR0036C & $\begin{array}{l}\text { MCAL09A06 } \\
\text { MCAL06A06 }\end{array}$ & MCAL09A06.1 & 437 \\
\hline
\end{tabular}

\subsubsection{Estratégia de clonagem}

A primeira etapa é desenhar primers específicos para cada candidato antigênico. A região referente à proteína madura é amplificada por PCR e clonada, primeiramente, no vetor pGEM-T. É feita a digestão e o fragmento resultante é ligado a um segundo vetor, pSecTag2A. Cada uma das etapas será descrita a seguir com mais detalhes. A Figura 4 apresenta um esquema da estratégia de clonagem utilizada. 


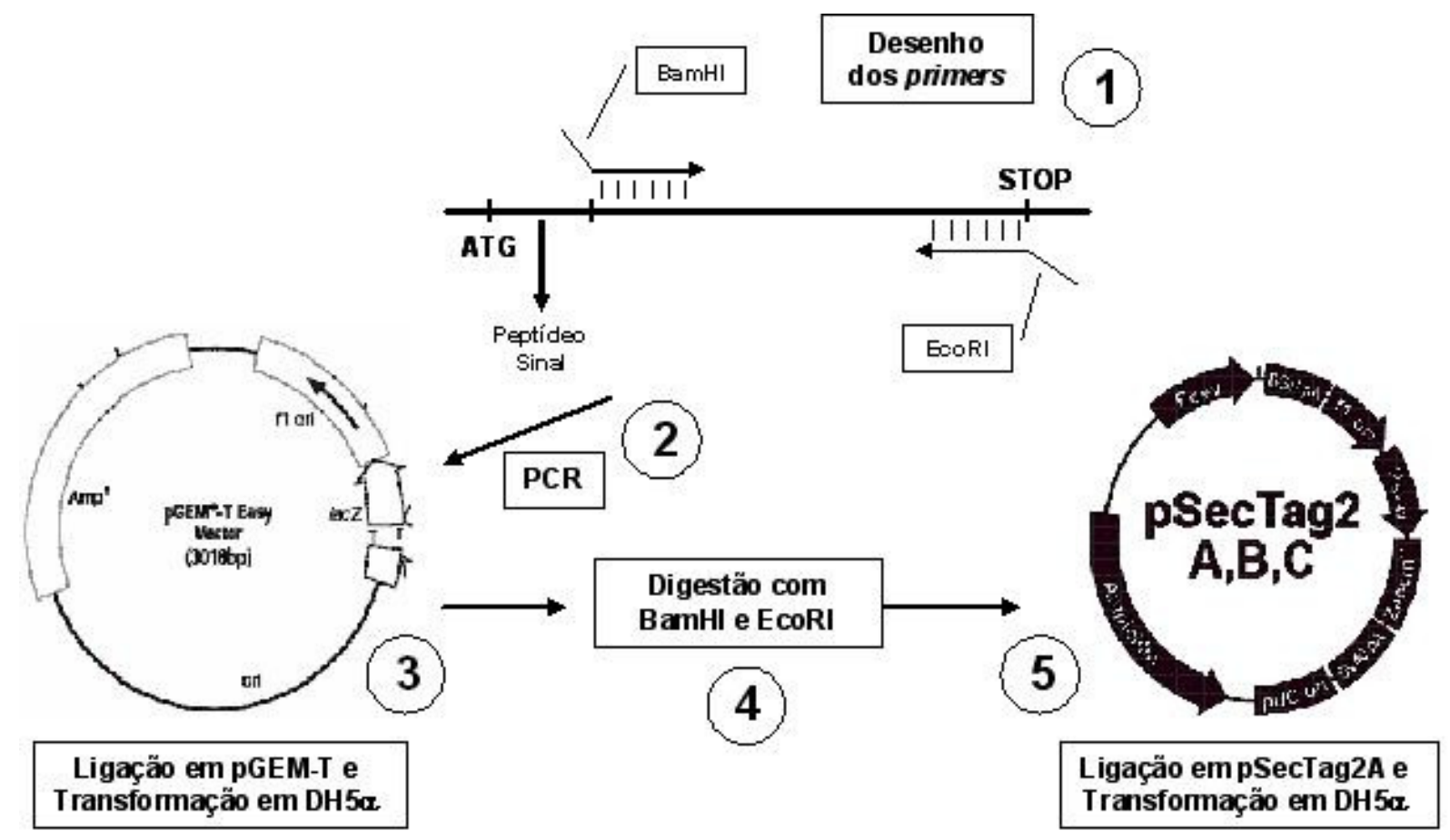

Figura 4: Esquema da estratégia utilizada para clonagem dos candidatos antigênicos.

\subsubsection{Desenho de primers}

Para os cinco candidatos, foram desenhados primers específicos de acordo com a Figura 5 abaixo:

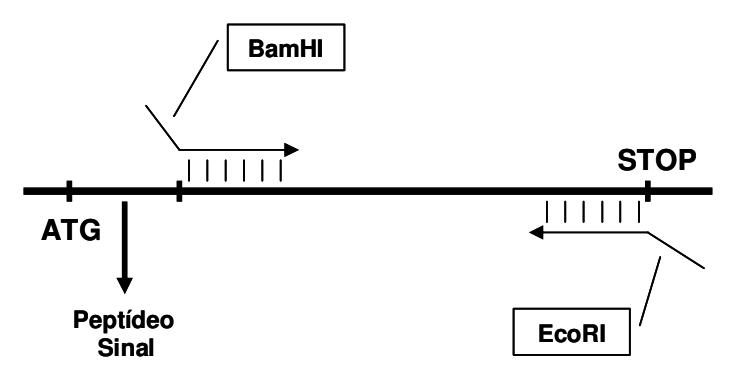

Figura 5: Esquema do desenho de primers específicos para clonagem dos candidatos antigênicos.

Os primers contêm sítios de restrição nas duas pontas para ligação posterior no vetor pSecTag2A. Para cada candidato, foram escolhidos dois clones representantes. Para cada grupo foram desenhados dois primers (Forward e Reverse). Os primers e seus respectivos nomes estão descritos a seguir. 
Atg1

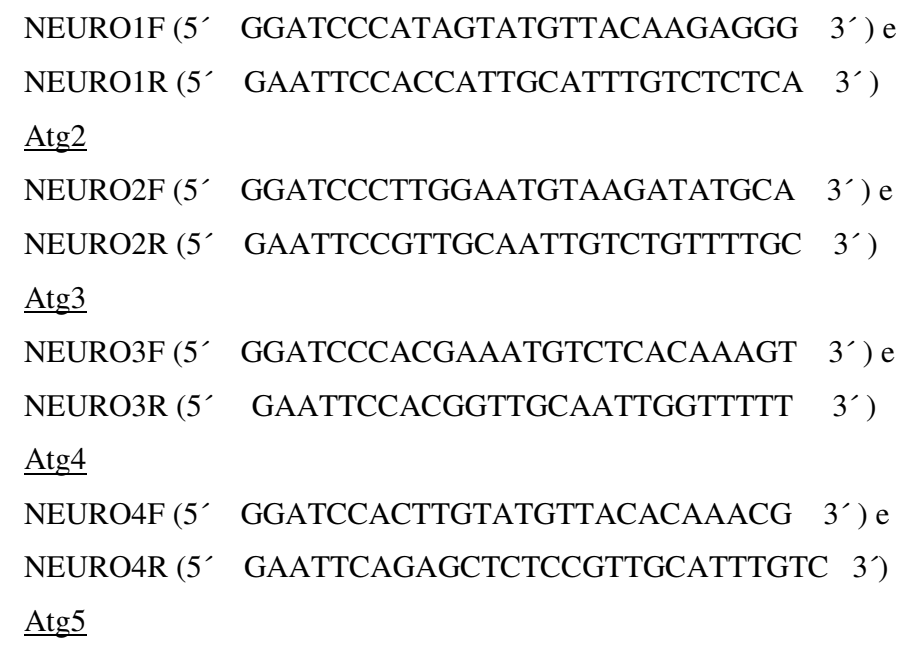

PLA2 1F (5' GGATCCCAACCTCATTAACTTCCAACG $\left.3^{\prime}\right)$ e PLA2 1R (5' GAATTCTTCGGCAACGATTGGGGTTCAT 3')

\subsubsection{PCR}

Com os primers específicos, foi realizada uma amplificação por PCR usando como molde os produtos de PCR dos fagos utilizados na geração das ESTs. As condições da amplificação foram alteradas no decorrer dos experimentos. A temperatura de anelamento adequada para a maioria dos PCRs foi de $55^{\circ} \mathrm{C}$, e a temperatura de extensão foi de $72^{\circ} \mathrm{C}$ para a $t a q$ polimerase $(1 \mathrm{~min} / \mathrm{kb})$. Os $50 \mu \mathrm{L}$ totais foram aplicados em gel de agarose 1,5\%. A banda resultante foi recortada e purificada com kit GFX ${ }^{T M}$ PCR (Amersham Biosciences). Esse procedimento foi realizado para cada um dos cinco candidatos.

\subsubsection{Clonagens em PGEM-T}

$\mathrm{O}$ fragmento purificado foi ligado no vetor $p G E M ®-T$ Easy (Promega), por complementariedade dos nucleotídeos adenina inseridos pela taq polimerase aos nucleotídeos T (timina) do vetor. A ligação foi transformada em bactérias DH5 $\alpha$. A fim de selecionar as colônias que continham o fragmento/clone, foi realizado um screening por PCR, já que os clones são muito pequenos e muito difíceis de serem detectados por meio de outros protocolos. No screening por PCR, usamos a própria colônia de bactéria como amostra para amplificação por PCR. Os primers utilizados são M13F e o primer reverse do candidato em estudo, seguindo as próprias condições de amplificação descritas acima. Com os clones positivos foram feitas minipreps com kit $G F X^{T M}$ 
(Amersham Biosciences). Os clones foram seqüenciados (ABI 3100 Applied Biosystems) para se conferir a ligação ao vetor.

\subsubsection{Digestão com BamHI e EcoRI}

Os clones ligados ao PGEM-T foram digeridos com as enzimas de restrição EcoRI (Invitrogen) e BamHI (Invitrogen). O vetor pSecTag2A (Invitrogen) também foi digerido com as mesmas enzimas para que fosse possível uma ligação entre vetor e fragmento/clone. A digestão permaneceu a uma temperatura de $37^{\circ} \mathrm{C}$ por 2 a 4 horas, dependendo do clone em estudo, e em seguida o inserto foi isolado em gel de agarose.

\subsubsection{Subclonagem em pSecTag2A}

Para a clonagem final foi escolhido o vetor de secreção extracelular, pSecTag2A. O "A" é referente à fase de leitura do sítio múltiplo de clonagem escolhido. O pSecTag2A é um vetor de expressão em células de mamíferos. Ele contém algumas fusões que ajudam na captura da proteína quando expressa in vitro, tal como cauda de histidina (His) e epítopo myc. É um vetor que se mantém na forma epissomal e secreta a proteína para fora da célula, por possuir o sinal de secreção da cadeia kappa das imunoglobulinas. A Figura 6 apresenta o mapa do vetor com os diferentes sítios de restrição, os promotores (promotor do tipo CMV e SV40) e as fusões.

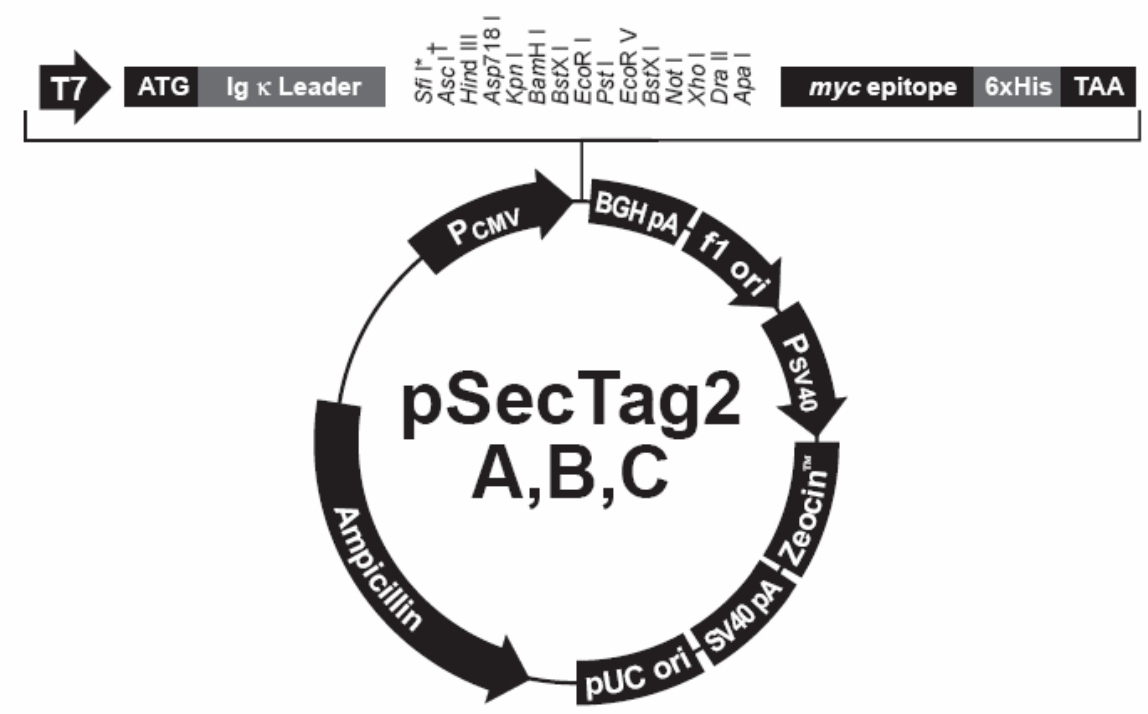

Figura 6: Mapa do vetor pSecTag2A utilizado na clonagem final realizada com os candidatos antigênicos. Nesse mapa estão apresentados os diferentes promotores, sítios de restrição e fusões. 
Os insertos foram, então, ligados ao pSecTag2A e, em seguida, transformados em bactérias DH5 $\alpha$. A seleção dos clones foi realizada por meio de screening por PCR, da mesma forma como mencionado na clonagem em pGEM-T, mas o primer forward utilizado é o T7F. Os clones positivos foram novamente purificados por meio do kit $G F X^{T M}$ (Amersham Biosciences). O seqüenciamento ocorreu ao final de todas as clonagens para se conferir a ligação do vetor ao clone e as prováveis mutações decorrentes de todo o processo.

\subsection{PROCESSO DE IMUNIZAÇÃo GENÉTICA}

\subsubsection{Maxiprep dos candidatos antigênicos para imunização genética}

Preparações de DNA em grande quantidade (maxipreps) foram feitas com o kit QIAGEN@ Plasmid Purification (Qiagen). Para isso, os clones obtidos a partir da clonagem são transformados novamente. São realizados pré-inóculos. Após aproximadamente 12 horas, esses pré-inóculos são expandidos em 300mL (proporção de 1:30) em meio LB com ampicilina. O inóculo cresce aproximadamente por 15 horas. No dia seguinte, começa a utilização do kit propriamente dito, segundo o protocolo do fabricante. A amostra final é eluída em $300 \mu \mathrm{L}$ e deve permanecer na geladeira por dois dias para uma eluição ótima.

Feitas as maxipreps, o DNA é quantificado espectrofotometricamente.

\subsubsection{Transfecção de clones em células eucarióticas}

Para a avaliação das construções, foram usadas células COS-07. As células COS-07, células de rim de macaco verde africano, são as mais utilizadas para transfecções do tipo transiente e, por esse motivo, optamos pela utilização delas. Nos ajudou o Dr. Geraldo S. Magalhães, pesquisador do Laboratório de Imunopatologia do Instituto Butantan.

O primeiro passo em uma transfecção é repicar as células a fim de que elas cresçam e atinjam uma confluência ao redor de $95 \%$. Feito isso, as células são tratadas com lipofectamina (Lipofectamine ${ }^{T M} 2000$, da Invitrogen). O meio utilizado é o meio DEMEN (meio Dulbecco High Glucose) com soro bovino. Em um tubo são misturados $250 \mu \mathrm{L}$ de meio DEMEN mais $4 \mu \mathrm{g}$ de plasmídeo. Em outro tubo, $250 \mu \mathrm{L}$ de meio DEMEN mais $10 \mu \mathrm{L}$ de lipofectamina. Após 5 minutos, o conteúdo dos dois tubos é 
misturado. Por conseguinte, após 20 minutos este conteúdo é derramado sobre as células. Dessa forma, tem início a transfecção. A cada 12 horas é necessário observar as condições fisiológicas das células: meio, formato das células e disposição delas. Nesse momento, o meio DEMEN com soro bovino é substituído por meio DEMEN sem soro bovino, pois há indícios de que o soro atrapalha a formação do complexo lipossomoDNA na transfecção. Após 24 horas tem início a expressão, portanto, a primeira coleta de sobrenadante aconteceu após 24 horas. Três coletas são suficientes para verificar a presença ou não de expressão da proteína. No último dia, são coletados os extratos de células, já que, apesar de a proteína estar em um vetor de secreção (pSecTag2A), podem ocorrer falhas e a proteína não ser secretada e continuar dentro da célula.

\subsection{IMUNIZAÇÃO DOS CANDIDATOS ANTIGÊNICOS ESCOLHIDOS}

A imunização dos candidatos citados acima foi feita em camundongos Balb/c, fêmeas, peso homogêneo (18-22g), com seis a oito semanas de idade. Cada grupo de cinco animais representa um candidato antigênico. Como controle, foi realizada uma sangria inicial antes da imunização, a fim de se obter o soro pré-imune. Foi feita uma sangria final, após a $3^{\mathrm{a}}$ dose da imunização. As doses ocorreram de quinze em quinze dias, com três doses para cada grupo (Figura 7).

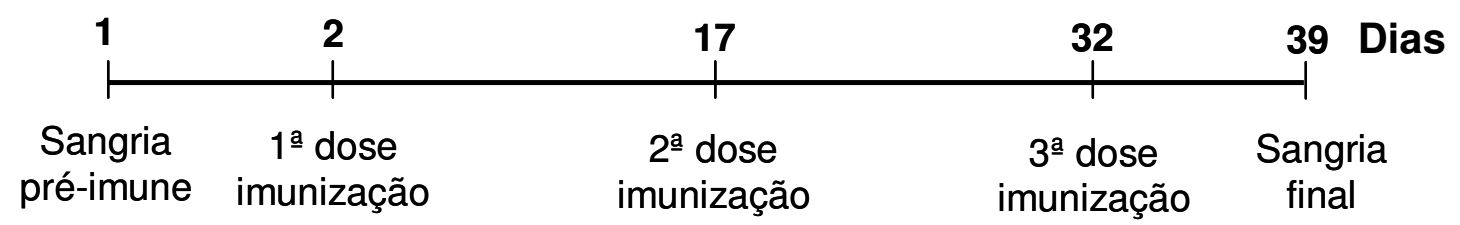

Figura 7: Esquema das dosagens aplicadas nos camundongos durante processo de imunização com os candidatos antigênicos selecionados.

Cada animal recebeu $100 \mu \mathrm{g}$ de DNA por dose, sendo no total 300 $\mu \mathrm{g} / \mathrm{animal}$. Para tanto, foi necessária a realização de maxiprep (Plasmid Purification ${ }^{\circledR}$, Qiagen) com cada um dos candidatos. As maxipreps foram quantificadas e, para facilitar sua utilização nas imunizações, todas as concentrações foram acertadas para $1 \mu \mathrm{g} / \mu \mathrm{L}$, dessa forma, $100 \mu \mathrm{L}$ seria o equivalente a $100 \mu \mathrm{g}$. Este acerto foi preparado com PBS 10X (Phosphate Buffered Saline) estéril e água MilliQ autoclavada (estéril). 
Os animais foram anestesiados intraperitonialmente com aproximadamente $200 \mu \mathrm{L}$ de anestésico (ketamina $500 \mu \mathrm{L} / 10 \mathrm{~mL}+$ xilazina $1000 \mu \mathrm{L} / 10 \mathrm{~mL}$ ). A injeção do DNA foi intramuscular (IM) e cada animal recebeu uma dose de $100 \mu \mathrm{L}$, divididos em $50 \mu \mathrm{L}$ em cada pata.

O sangue foi coletado em tubos eppendorf e colocado na estufa a $37^{\circ} \mathrm{C}$ por 1 hora. Depois, por mais 1 hora a $4^{\circ} \mathrm{C}$ (em geladeira). O sangue é centrifugado por 10 minutos, a $3.000 \mathrm{rpm} \mathrm{em} 4^{\circ} \mathrm{C}$. O soro então é retirado e mantido em freezer a $-20^{\circ} \mathrm{C}$.

\subsection{EXPRESSÃO E PURIFICAÇÃO DAS PROTEÍNAS RECOMBINANTES EM E. COLI}

A fim de termos antígenos para o teste dos soros, fizemos a expressão de três dos cinco antígenos baseadas em construções para expressão em E. coli de que já dispunhamos no laboratório (PRIETO DA Silva, 2001b e DE OliveIRA et al., 2003). Primeiramente é feita a transformação em bactéria, no caso a E. coli DE3 starpLys (resistência a cloranfenicol e ampicilina). Um pré-inóculo em $25 \mathrm{~mL}$ de meio LB (SAMBROOK et al., 1989) é preparado e, no dia seguinte, é expandido para 500mL + $15 \mathrm{~mL}$ de pré-inóculo. É crescido em meio de cultura LB com ampicilina e clorafenicol até atingir $\mathrm{DO} \approx 0,6$. Antes da indução, é retirada uma alíquota de $1 \mathrm{~mL}$ de amostra nãoinduzida (NI). É colocado então IPTG (indutor de expressão) por 2 ou 3 horas a $37^{\circ} \mathrm{C}$.

Após a indução, uma alíquota de $1 \mathrm{~mL}$ do induzido é retirada e o restante é centrifugado a $5.000 \mathrm{rpm}$ em $5^{\circ} \mathrm{C}$, por 15 minutos. O pellet é congelado ou ressuspendido com um tampão, de acordo com o pI da proteína (ponto isoelétrico). Como todas as proteínas têm pI básico, o tampão utilizado foi o Tris pH 6,8 0,1M (pI $\pm 1,5$ ) (Tabela 6).

Tabela 6: As proteínas Atg1, Atg2 e Atg5 com seus respectivos pontos isoelétricos ( $\mathrm{pl}$ ) e 0 nome da proteína de acordo com a similaridade com o banco de dados (Blastx).

\begin{tabular}{|c|c|c|}
\hline Nome & Proteína & pI \\
\hline Atg1 & Neurotoxina 8 & 7,97 \\
\hline Atg2 & Neurotoxina $7 / 3 / 1$ & 8,58 \\
\hline Atg5 & PLA2 & 8,24 \\
\hline
\end{tabular}


As bactérias ressuspendidas são lisadas em FrenchPressure ${ }^{\circledR}$. O lisado é centrifugado por 30 minutos em $4^{\circ} \mathrm{C}$, a $10.000 \mathrm{rpm}$. O sobrenadante é coletado e passado na coluna de cromatografia de anfinidade a metal (sepharose carregada com $\mathrm{Ni}^{2+}$ ), com fluxo de cerca de $1 \mathrm{ml}$ por minuto. São feitas lavagens com várias concentrações de imidazol (5mM, 20mM, 40mM e $60 \mathrm{mM})$ no mesmo tampão e, no final, a proteína é eluída com 1M imidazol (25 alíquotas de 1mL).

O corpúsculo de inclusão é lavado primeiramente com uréia 1M. É centrifugado, o sobrenadante é coletado e uma alíquota é retirada para o gel de SDS-PAGE (Eletroforese em Gel de Poliacrilamida). O corpúsculo é ressuspendido depois em uréia 8M. Uma alíquota dela é aplicada no gel para se verificar a presença de proteína no corpúsculo. O corpúsculo em uréia $8 \mathrm{M}$ é passado na coluna e o flow through (material não adsorvido) é coletado. No decorrer do processo da purificação, a concentração de uréia é diminuída de $8 \mathrm{M}$ para 6M. É feita uma lavagem com imidazol 60mM (cinco alíquotas de $5 \mathrm{~mL}$ ) e, depois, outra lavagem com imidazol 1M. São retiradas 25 alíquotas de $1 \mathrm{~mL}$, da mesma forma que na purificação do sobrenadante. Todas as alíquotas coletadas são colocadas no gel para visualização. O gel é corado com Comassie Blue (coloração azulada) e fixado.

Para utilizar as proteínas purificadas no coating de ELISA (Enzyme-linked Immunosorbent Assay), é necessário retirar o imidazol presente nas amostras coletadas. Para tanto, é feita a diálise. Como se tratava de corpúsculo de inclusão, a solução continha uréia. Para facilitar, as três diálises foram feitas em uma mesma solução de 1L contendo uréia $6 \mathrm{M}$ e tampão $\mathrm{NaCl}$-Tris $\mathrm{pH}$ 6,8, porém cada proteína estava em membrana diferente. A membrana utilizada foi de $3 \mathrm{kDa}$, devido ao tamanho das proteínas $(9 \mathrm{kDa}-12 \mathrm{kDa})$. Após 3 horas, a solução é trocada e a concentração final de imidazol passa a ficar ao redor de $0,85 \mathrm{mM}$.

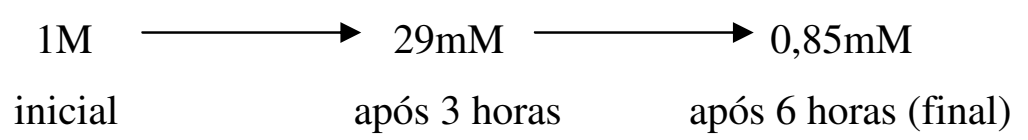

Para se fazer a curva de BSA (Albumina Sérica Bovina), a fim de se quantificar a proteína obtida após a diálise, foram colocadas várias concentrações de BSA em gel de SDS-PAGE juntamente com a proteína a ser quantificada, conforme descrito na figura correspondente nos resultados. A intensidade da banda nos mostra a quantidade de proteína contida naquela alíquota. A curva tem de ser precisa para que seja possível a 
quantificação sem erros. A quantificação é feita por densitometria de bandas em fotodigitalizador Eagle Eye, que interpreta a intensidade da banda em valor numérico.

\subsection{ANÁLISE DA RESPOSTA IMUNOLÓGICA}

\subsubsection{ELISA}

A melhor forma de análise da resposta imune proveniente das imunizações é o método imunoenzimático ou ELISA (Enzyme-linked Immunosorbent Assay). Primeiramente, é necessário se fazer o coating de ELISA, ou seja, adicionar a proteína recombinante que se ligará ao soro (anticorpo) proveniente das imunizações com DNA em camundongos. A quantificação da proteína é essencial nessa etapa, já que são colocados $2 \mu \mathrm{g}$ de proteína em cada poço da placa de 96 well (96 poços) de ELISA. A proteína é diluída em tampão de coating $\mathrm{NaHCO}_{3}+\mathrm{Na}_{2} \mathrm{CO}_{3} 0,05 \mathrm{M}$ pH9,6. A placa com o coating é deixada dentro da geladeira, a $4^{\circ} \mathrm{C}$, embrulhada com plástico PVC. A proteína adere à parede da placa. $\mathrm{O}$ excesso é removido no dia seguinte.

Após isso, é feito um bloqueio da placa com leite 10\% em PBS-T (Phosphate Buffered Saline + Tween) antes de se iniciar as incubações com os anticorpos primário e secundário. O anticorpo primário é o soro proveniente da imunização. São feitas diluições, nesse caso, a partir de 1:20-1:10240. A primeira coluna da placa não possui coating, apenas o tampão de coating. A segunda coluna é o branco, ou seja, possui coating, mas não é colocado o soro primário. A partir da terceira coluna, têm início as diluições. O anticorpo primário é incubado durante $1 \mathrm{~h} 30$ em uma solução de BSA 1\% + PBS-T $0,1 \%$, a $37^{\circ} \mathrm{C}$. O bloqueio de leite é substituído pelo BSA.

Após a incubação e lavagem, a placa é incubada com anticorpo secundário em todos os poços, inclusive o controle sem coating e o branco. $\mathrm{O}$ anticorpo secundário, neste caso, é o IgG anti-mouse conjugado com peroxidase. A incubação deve ocorrer por uma hora a $37^{\circ} \mathrm{C}$.

É feita uma última lavagem e a placa é revelada. É preparada uma solução de 0,004\% OPD (ortofenilenodiamina) $+0,005 \% \mathrm{H}_{2} \mathrm{O}_{2}$ (água oxigenada) em tampão citrato-fosfato (ácido cítrico 0.1M. e fosfato de sódio 0.2M) que será colocada na placa. $\mathrm{O}$ OPD reage com a $\mathrm{H}_{2} \mathrm{O}_{2}$ na presença da peroxidade. A coloração amarelada passa a vigorar devido à oxidação do OPD, que garante o reconhecimento da proteína (coating) com o anticorpo primário (soro da imunização em camundongos). A reação é bloqueada 
com adição de ácido sulfúrico $\mathrm{H}_{2} \mathrm{SO}_{4} 8 \mathrm{~N}$ assim que houver titulação aparente (amarelo mais intenso para menos intenso). Bloqueado, o ELISA pode ser lido. Para o OPD, o comprimento de onda é $492 \mathrm{~nm}$. O branco é a média da coluna sem o soro primário. A titulação é a diluição onde a Absorbância for próxima de 0,100 .

\subsubsection{Western Blot}

Para o Western blot, as amostras são aplicadas em gel SDS-PAGE (SAMBROOK et al., 1989). Dá-se início à transferência do gel para uma membrana de nitrocelulose. A membrana é colocada face-a-face com o gel, e uma corrente elétrica (350mA) é aplicada para mover as proteínas para a membrana. A ligação das proteínas à membrana é baseada tanto em interações hidrofóbicas como em interações de cargas entre a membrana e as proteínas. Após 1h30, o gel é corado com Ponceau $S$ a fim de se verificar a presença do perfil de proteínas presentes na amostra, documentado e descorado com água.

O bloqueio da ligação não-específica é feito ao se colocar a membrana em uma solução diluída de leite seco desnatado (10\%), com pequena quantidade de detergente, como Tween $20(0,05 \%)$.

No dia seguinte, ocorrem as incubações. Primeiramente, a membrana é incubada com anticorpo primário na presença de leite. A solução permanece em agitação leve por aproximadamente 1 hora. Depois de se enxaguar a membrana para remover o anticorpo primário não ligado, ela é exposta a outro anticorpo conjugado com uma enzima, direcionada a porções espécies-específicas do anticorpo primário. Mais comumente, uma peroxidase é usada em conjunto com um agente quimioluminescente, e a reação produz fluorescência proporcionalmente à quantidade de proteína.

Depois das sondas não-ligadas serem lavadas, o Western blot está pronto para detectar a proteína de interesse. A membrana é, dessa forma, revelada.

Em caso de necessidade de reutilização da membrana para outras incubações, é necessário lavá-la com um tampão denominado Stripping Buffer (100nM $\beta$-mercapto, $2 \%$ SDS, $62.5 \mathrm{mM}$ Tris HCL pH 6.7). Este tampão permite a reutilização da membrana (reprobing). 


\section{RESULTADOS E DISCUSSÃO}

\subsection{O TRANSCRIPTOMA}

\subsubsection{Banco de Seqüências}

A descrição de propriedades farmacológicas, ações patológicas, atividades catalíticas, entre outros, ainda constitui a base fundamental no entendimento do funcionamento dos venenos animais. Entretanto, nos dias de hoje, a atribuição dessas propriedades só passa a ter valor reconhecido quando vinculada às suas bases moleculares. Portanto, o entendimento aprofundado do funcionamento dos venenos de serpentes requer antes de tudo uma boa compreensão de sua composição em termos bioquímicos.

O estudo de venenos, baseado no fracionamento cromatográfico de proteínas e caracterização particularizada de componentes é um processo lento e trabalhoso. Tecnologias proteômicas, por outro lado, permitem um rápido conhecimento da diversidade de substâncias presentes no veneno, porém, metodologicamente, a obtenção de informações extensivas sobre a estrutura primária de proteínas ainda é um desafio. A disponibilidade de amostra, a existência de equipamentos com funções específicas, a qualidade da espectrometria de massas, a necessidade de modificações químicas das amostras são alguns dos requisitos para se obter uma informação estrutural por vias proteômicas (CALVETE et al., 2007). Por outro lado, ainda que limitada pela natureza indireta da informação, as abordagens transcriptômicas têm sua vantagem na facilidade de se obter grandes quantidades de informação sobre seqüências de toxinas e traçar um perfil da expressão gênica nas glândulas de veneno (JUNQUEIRA DE AZEVEDO \& Ho, 2002).

A partir desse princípio, alguns trabalhos buscaram realizar a caracterização transcriptômica de diversas espécies, conforme descrito na Introdução deste trabalho. Porém nenhum deles abordou sistematicamente uma espécie de elapídeo terrestre e muito menos espécies de cobras-corais, cujo veneno ainda é pouco conhecido. Essa foi uma das razões que nos motivou ao presente estudo.

A análise do transcriptoma da serpente Micrurus corallinus foi feita então com base em bibliotecas pré-existentes construídas em fago $\lambda G T 11$, em 1992, pelo Dr. Paulo Lee Ho, nosso colaborador nesse projeto (Ho et al., 1995). Foram utilizadas duas sub- 
bibliotecas com faixas de tamanho de cDNAS diferentes, GI (>600pb) e GII (400 a 600 pb), construídas a partir do mRNA de dez espécimes. Dessas bibliotecas, preparamos e seqüenciamos cerca de 1.500 clones para que fossem observados os transcritos mais abundantes.

Diferentemente de outros trabalhos de nosso grupo, estas bibliotecas haviam sido preparadas em fago e foi necessária a padronização de um procedimento de geração de ESTs a partir de colônias de fagos, tendo em vista que esse projeto utilizava uma metodologia diferente daquela usualmente utilizada no nosso Laboratório para geração de ESTs. Muitos testes foram realizados a fim de se padronizar a metodologia, diminuir os custos e aumentar o rendimento. A primeira padronização foi no PCR de amplificação dos cDNAs e, posteriormente, na purificação do produto de PCR.

Com relação à padronização do PCR, foram realizados diversos testes-pilotos para determinar a quantidade mínima necessária de primer e enzima taq polimerase para que houvesse uma amplificação eficiente, porém com custo não muito alto. Duas enzimas taq polimerases foram testadas (Taq DNA Polymerase Recombinant, da Invitrogen, e Platinum $® T a q$ DNA Polymerase, da Invitrogen). Ambas produziram o mesmo rendimento, porém a taq platinum, apesar de mais cara, apresenta uma vantagem por estar complexada a um anticorpo que inibe atividade polimerásica em temperatura ambiente. Dessa forma, pode ser manuseada na bancada e não obrigatoriamente no gelo - como ocorre com as enzimas taq comuns - além de evitar a amplificação errônea de DNA. O custo é um ponto que levamos em consideração pelo fato de estarmos trabalhando em larga escala (placas de 96 poços ou 96well) e não com clones individuais. As quantidades mínimas determinadas para que houvesse uma amplificação eficiente avaliada em gel de agarose foram: $10 \mu \mathrm{L}$ de fago $\lambda g t 11 D, 1 \mu \mathrm{L}$ de primer $\lambda g t 11 F, 1 \mu \mathrm{L}$ de primer $\lambda g t 11 R e 0,5 \mu \mathrm{L}$ de taq polimerase.

Um dos grandes esforços que realizamos foi a padronização da purificação do produto de PCR. Quando se trabalha com clones individuais, a utilização de kits de purificação a partir de gel é bastante interessante e vantajosa. Mas quando se trabalha em larga escala, o trabalho demandado para manipulação individual de cada amostra e o custo bastante elevado desses kits os tornam menos atraentes. Sistemas de purificação em larga escala como placas de filtro de 96 poços também têm custo elevado. Dessa forma, avaliamos três técnicas (separação em gel de agarose 1\% seguida de purificação física por meio da utilização do kit $G F X^{T M} P C R$, purificação física diretamente na 
coluna GFX e purificação química com enzimas que removem os excedentes de primers e nucleotídeos) e comparamos o rendimento juntamente com o custo. A relação custobenefício no último caso foi maior e mais favorável. E por essa razão optamos por utilizar o tratamento químico para purificação do produto de PCR.

Dessa forma, pudemos gerar as ESTs que foram então processadas bioinformaticamente, incluindo além do agrupamento (clustering) também a anotação e as análises estatísticas da expressão das toxinas e proteínas celulares encontradas. No processo bioinformático de agrupamento ou clusterização, realizado com o programa $C A P 3$, observamos algumas particularidades. Sabe-se que as neurotoxinas presentes nesses venenos são muito diversas e poucas substituições em alguns resíduos são capazes de mudar a classe na qual essas proteínas se inserem. Dessa forma, testamos três estringências diferentes para agrupamento das seqüências (95\%, $98 \%$ e $99 \%$ de identidade), para avaliar como se comportaria o agrupamento de cDNAs. A idéia era evitar que diferentes isoformas se reunissem no mesmo cluster. A Tabela 7 ilustra as quantidades de grupos encontrados.

Tabela 7: Três valores diferentes de identidade testados como parâmetro de estringência no CAP3 e os resultados obtidos.

\begin{tabular}{|c|c|c|c|}
\hline VALOR DE IDENTIDADE (\%) & CONTIGS & SINGLETS & TOTAL \\
\hline 95 & 125 & 420 & 545 \\
\hline 98 & 120 & 476 & 596 \\
\hline 99 & 120 & 564 & 684 \\
\hline
\end{tabular}

A seguir, identificamos previamente os clusters codificantes para neurotoxinas (conforme análise por similaridade, Blastx) e notamos que, com 95\% de identidade, diferentes cDNAs de neurotoxinas não eram separados em grupos diferentes, já com 99\% ocorria uma separação exagerada de alguns grupos protéicos que não deveriam ser divididos. Dessa forma, optamos por utilizar o valor de $98 \%$ de identidade como parâmetro de estringência no CAP3 (valor usado em outros casos, JUNQUEIRA DE AZEVEDO et al., 2006) e, em seguida, separar manualmente as seqüências de neurotoxinas que não deveriam pertencer a um mesmo cluster, conforme discutido adiante. Assim, realinhamos algumas seqüências em novos clusters, que foram reinseridos na nossa base de dados. 
O banco final de ESTs de $M$. corallinus contém então 1.438 seqüências de clones que foram agrupadas em 611 clusters, incluindo 483 clusters compostos por clones individuais (singlets) e 128 clusters com duas ou mais seqüências (contigs). Após aplicação de filtro contra sequiências de RNA ribossomal, DNA mitocondrial e vetores ou outros contaminantes, $5 \%$ dos clones foram desconsiderados das análises subseqüentes.

A análise com o banco de dados via Blast revelou que, de 611 clusters, 485 (correspondente a 1.250 clones ou $92 \%$ do total) produziram semelhanças significativas com o banco de dados $\left(e\right.$-value $\left.<10^{-05}\right)$ e outros 103 clusters (107 clones ou 8\% do total) não puderam ser identificados. Dessa forma, foi possível realizar a anotação, tabulada em planilha Excel (ilustrada no Anexo I), de onde extraímos as informações mais relevantes dos resultados que serão apresentados a seguir.

As informações identificadas foram divididas de acordo com as duas funções gerais esperadas para os transcritos da glândula de veneno: toxinas (funções tóxicas) e demais transcritos envolvidos nas funções celulares (funções não-tóxicas).

Tanto os transcritos enquadrados na categoria "toxinas" como os "transcritos celulares" tiveram representação equivalente no perfil geral de proteínas da glândula (aproximadamente $46 \%$ do total de clones cada um). Entretanto, as proteínas celulares são mais diversificadas (392 clusters). Isso fica mais evidente quando observamos a redundância (clones/cluster) de cada categoria. As toxinas têm média de 6,7 clones para cada cluster enquanto os transcritos celulares apresentam valor de 1,6. Isso significa que cada toxina é, em média, quatro vezes mais expressa do que um dado transcrito celular (Tabela 8).

Tabela 8: Representação dos clusters obtidos a partir das ESTs da glândula de veneno de $M$. corallinus.

\begin{tabular}{|l|c|c|c|c|}
\hline \multicolumn{1}{|c|}{ Categoria } & Clusters & Clones & $\begin{array}{c}\text { Redundância } \\
\text { clones/clusters) }\end{array}$ & $\begin{array}{c}\text { Representação do } \\
\text { total de clones (\%) }\end{array}$ \\
\hline No hit/ genômico/ íntrons & 103 & 107 & 1,0 & 7,9 \\
\hline Sequências similares & 485 & 1250 & 2,6 & 92,1 \\
\hline $\begin{array}{l}\text { Similaridade com } \\
\text { transcritos/proteínas tóxicas }\end{array}$ & 93 & 625 & 6,7 & 45,9 \\
\hline $\begin{array}{l}\text { Similaridade com } \\
\text { transcritos/proteínas celulares }\end{array}$ & 392 & 625 & 1,6 & 46,2 \\
\hline $\begin{array}{l}\text { Outros (mitocondrial, RNA } \\
\text { ribossomal, vetor) }\end{array}$ & 23 & 81 & 3,5 & 5,4 \\
\hline
\end{tabular}


Ao observar os tipos particulares de toxinas (Figura 8), podemos perceber que as proteínas de três dígitos (neurotoxinas) são os transcritos mais abundantes, seguidas de fosfolipases do tipo A2 (PLA2), como era esperado. Depois vêm as lectinas do tipo C e o precursor do peptídeo natriurético. As outras classes de toxinas encontradas são menos abundantes (Figura 8). Quando verificamos o perfil das possíveis proteínas celulares (Figura 9), o padrão apresentado segue o que se espera de uma glândula secretória, caso da glândula de veneno, na qual as proteínas mais expressas estão relacionadas à transcrição/tradução.

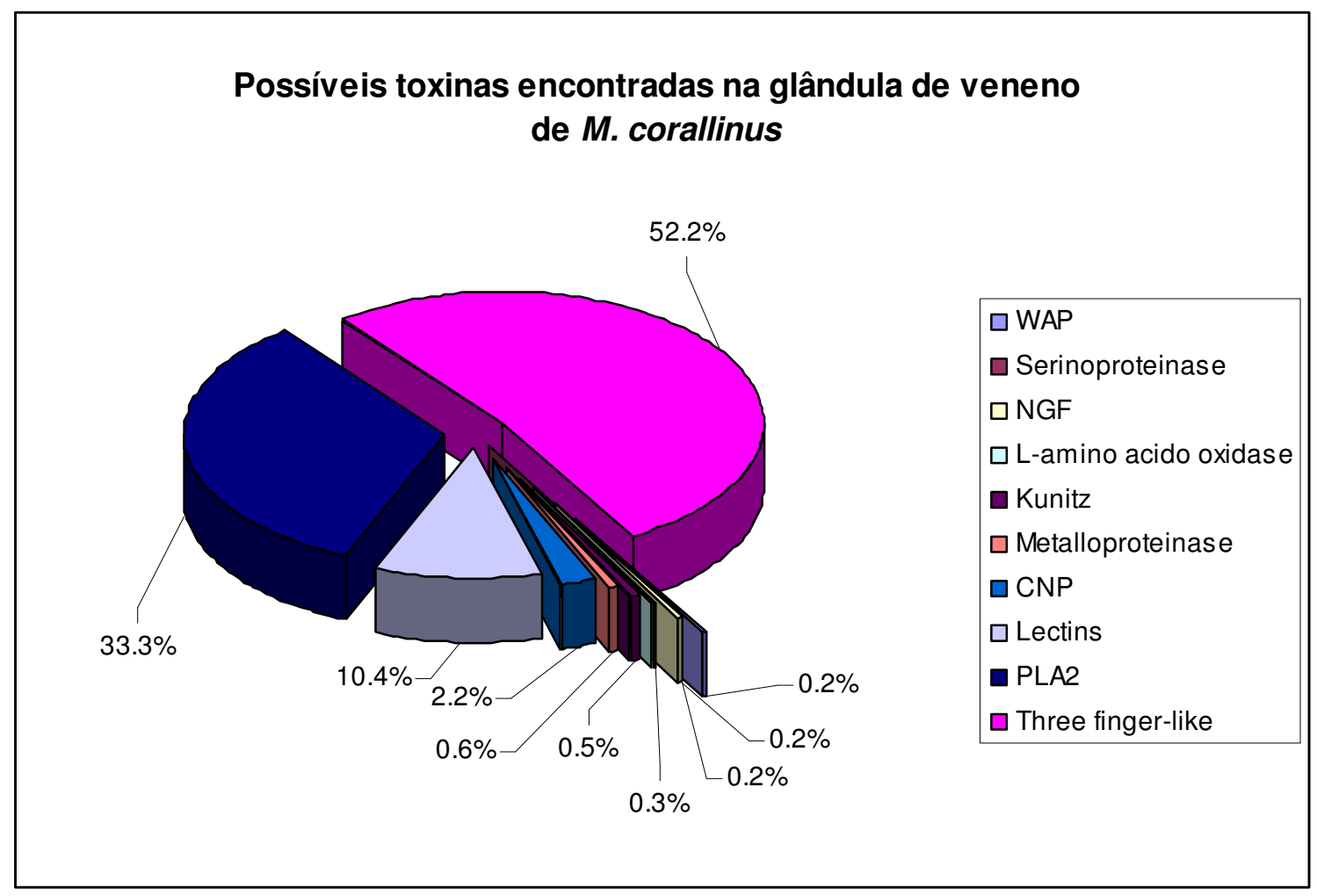

Figura 8: Representação gráfica da proporção dos tipos de toxinas encontradas em glândulas de veneno de Micrurus corallinus (\% do total de clones de toxinas). 


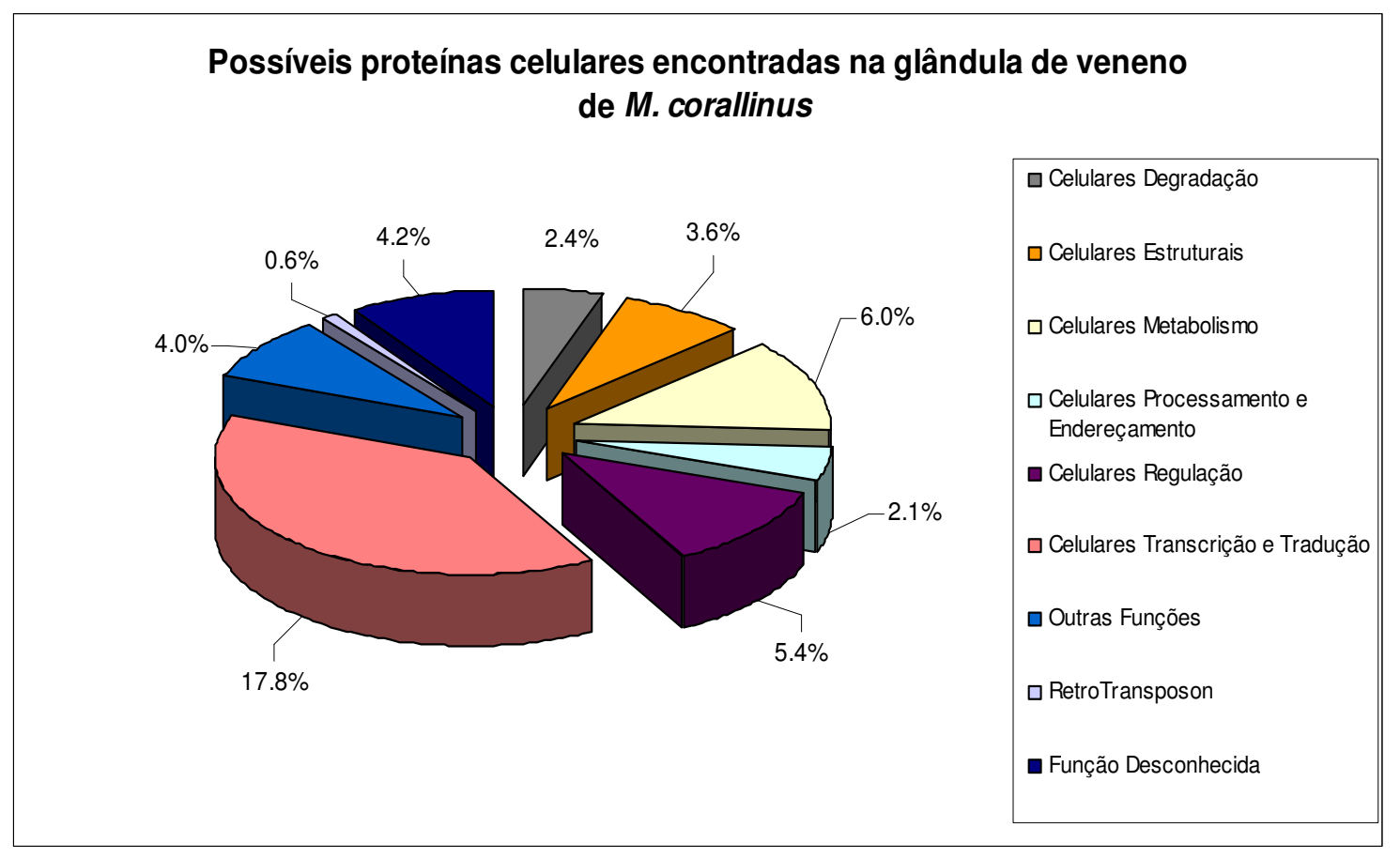

Figura 9: Representação gráfica da proporção dos tipos de proteínas celulares encontradas em glândulas de veneno de Micrurus corallinus (\% do total de clones de proteínas celulares).

\subsubsection{Análise dos cDNAs de toxinas identificados no banco de ESTs}

Foi possível identificar dez classes de toxinas, que representam aproximadamente 46\% (625 clones agrupados em 93 clusters) de todas as informações contidas neste banco transcriptômico (Tabela 9). É um valor esperado quando comparado com outros viperídeos (JUNQUEIRA DE AZEVEDO et al., 2006; QINGHUA et al., 2006; WAGSTAFF \& HARRISON, 2006), já que esse tecido é especializado na síntese de proteínas tóxicas, e uma biblioteca de cDNA da glândula de veneno desse animal deve representar a composição e a diversidade das toxinas expressas nele. A análise de cada grupo de toxinas está representada a seguir, de acordo com sua abundância. 
Tabela 9: Representação dos tipos de toxinas encontradas na glândula de veneno de Micrurus corallinus, com o respectivo número de clusters e clones.

\begin{tabular}{cccc}
\hline TOXINAS & no de clusters & no de clones & $\%$ do total \\
\hline WAP & 1 & 1 & $0.1 \%$ \\
NGF & 1 & 1 & $0.1 \%$ \\
Serinoprotease & 1 & 1 & $0.1 \%$ \\
L-aminoácido oxidase & 2 & 2 & $0.1 \%$ \\
Kunitz & 2 & 3 & $0.2 \%$ \\
Metaloprotease & 1 & 4 & $0.3 \%$ \\
Peptídeo Natriurético & 5 & 14 & $1.0 \%$ \\
Lectinas do tipo C & 13 & 65 & $4.7 \%$ \\
PLA2 & 12 & 208 & $15.3 \%$ \\
Proteína de três dígitos & 55 & 326 & $24.0 \%$ \\
\hline TOTAL & 93 & 625 & $\mathbf{4 5 . 9 \%}$ \\
\hline
\end{tabular}

\subsubsection{Proteína de três dígitos}

Esse grupo de toxinas, as proteínas de estrutura em três dígitos (3FTx), é o que apresentou maior abundância de seqüências expressas ( $\sim 52 \%$ do total de toxinas) no padrão obtido da glândula de veneno de $M$. corallinus. Essas proteínas são pequenas, com menos de oitenta aminoácidos e geralmente com quatro, às vezes cinco, pontes dissulfeto. Possuem efeitos farmacológicos muito distintos (PRIETO DA SILVA, 2001b e ENDO \& TAMIYA, 1991).

A análise da montagem dos clusters de 3FTx chegou após uma revisão a um número final de 326 clones ( 24\% do total) agrupados em 55 clusters. Ocorre que muitos desses clusters foram recriados manualmente após a montagem inicial pelo programa $C A P 3$, pois se notou que alguns dos contigs iniciais estavam agrupando, na verdade, variantes diferentes. Então, cada contig inicial foi inspecionado visualmente para identificar os SNPs (single nucleotide polymorphisms) que fossem comuns a mais de uma seqüência dentro da montagem. Quando tais SNPs eram encontrados, as respectivas sequiências eram removidas e arranjadas em um novo cluster, após avaliação da qualidade das bases no ponto. Assim, foram obtidos os 55 clusters.

Quanto às proteínas derivadas desses clusters, em uma análise comparativa não foi possível agrupá-las em tipos funcionais definidos, baseando-se na sequiência, por exemplo, pelo número de cisteínas conservadas ou de acordo com o tamanho do $\mathrm{C}$ terminal (NIRTHANAN \& GWEE, 2004), já que a diversidade de neurotoxinas observadas foi extremamente grande. Além disso, visto que é o primeiro banco transcriptômico de 
um membro da Família Elapidae, tivemos dificuldade em identificar as possíveis funções e os possíveis ortólogos em outras espécies por não haver dados suficientes para sua validação na literatura. Dessa forma, optamos por organizar essas toxinas de acordo com a semelhança das seqüências entre si. Assim, separamos três lotes diferentes de cDNAs de 3FTx.

Os dois primeiros lotes contêm seqüências muito similares às quatro possíveis $\alpha$ neurotoxinas já descritas na literatura para Micrurus corallinus (Ho et al., 1995). O primeiro foi denominado homolog 7/3/1 (representando os cDNAs das isotoxinas nxh7, nxh3, nxh1) por serem semelhantes entre si e apresentarem diferenças significativas na região referente ao peptídeo sinal e em alguns poucos aminoácidos da região referente à proteína madura. A proteína madura apresenta 57 aminoácidos. O segundo lote refere-se ao homolog 8 (representando o cDNA nxh8), uma forma peculiar que traz diferenças significativas na região referente à proteína madura quando comparado ao homolog 7/3/1 (PRIETO DA SiLva, 2001b). Comparando esse dois lotes entre si, nxh8 compartilha apenas $42 \%$ de similaridade com o grupo homolog 7/3/1. A forma madura apresenta 65 aminoácidos. A organização de seu cDNA é similar à descrita para o precursor da erabutoxina a de Laticauda semifasciata (TAMIYA et al., 1985). A nxh8 apresenta dez cisteínas que podem formar cinco pontes dissulfeto. Foi constatado que a nxh8 pode se ligar ao próprio receptor nicotínico de acetilcolina (nAChR) ou compartilhar um epítopo funcional com as $\alpha$-neurotoxinas, e que o soro anti-nxh8 (recombinante) pode impedir a ligação dos componentes pós-sinápticos do veneno de $M$. corallinus ao nAChR (PRIETO DA SILVA, 2001b).

O restante das neurotoxinas encontradas (grupo denominado "outras neurotoxinas") não é propriamente um grupo de seqüências relacionadas, mas sim novas 3FTx que obtiveram um valor de identidade em torno de 50\% com seqüências de 3FTx do banco de dados. Na Figura 10, estão representadas todas as 3FTx encontradas, incluindo cada cluster que representa o grupo "outras neurotoxinas". Estas foram reagrupadas por semelhança e serão mais bem detalhadas no item 4.2.1.

Ainda com relação à estrutura de três dígitos, um cluster interessante foi encontrado. O cluster MCOR0226S, com apenas um clone, apresenta semelhança com o precursor de proteína Ly-6E de linfócitos de Gallus gallus (Toulon et al., 1988). Tratase de uma 3FTx, porém provavelmente não-tóxica. As proteínas da família Ly-6 formam um grupo de receptores da superfície celular envolvidos na ativação de 
leucócitos (ToulON et al., 1988), por isso acreditamos que o cluster MCOR0226S não deva ser uma toxina.

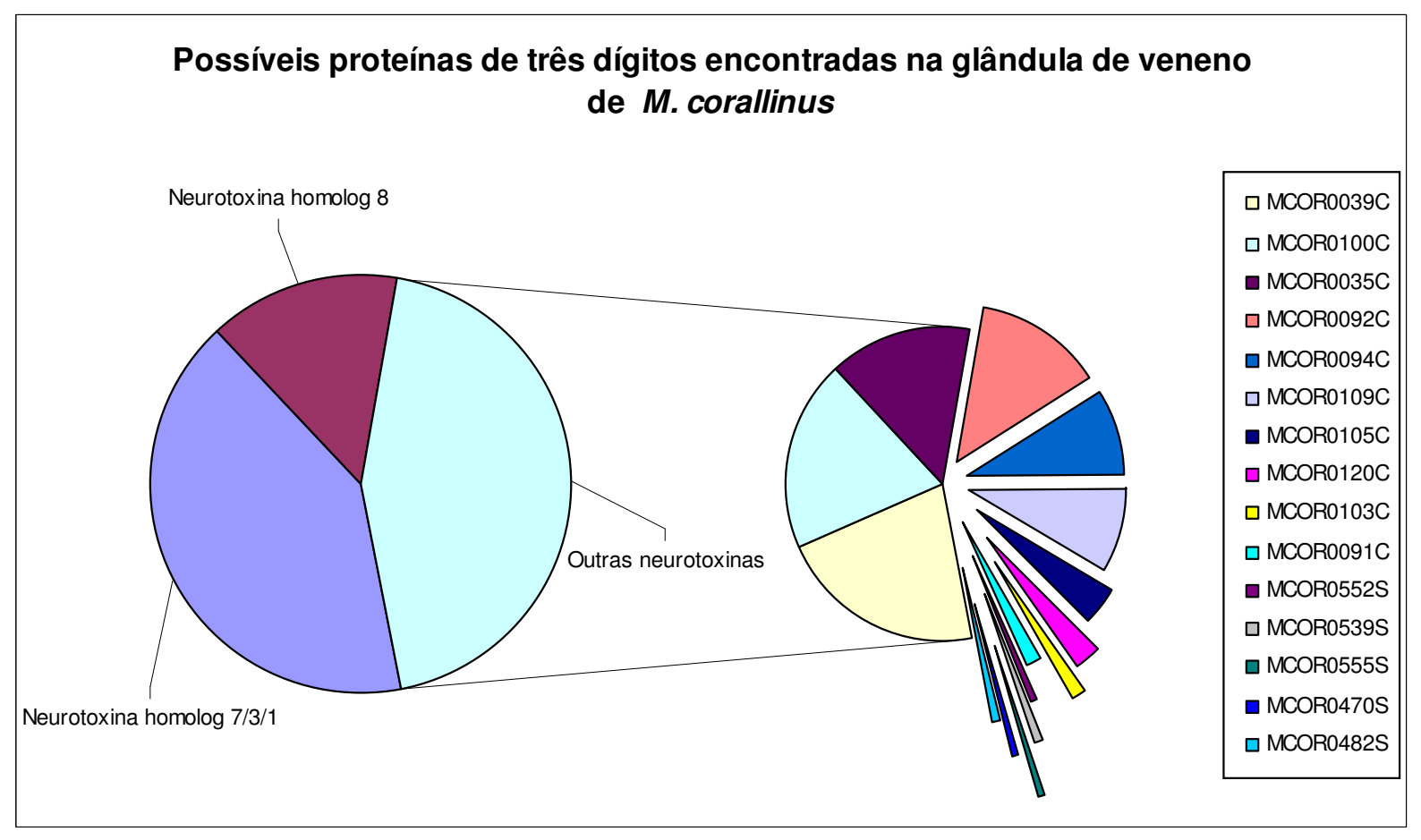

Figura 10: Proteínas de três dígitos encontradas na glândula de veneno de $M$. corallinus ( $\mathrm{n}^{\circ}$ de clones/grupo - gráfico maior e $\mathrm{n}^{\circ}$ de clones/cluster - gráfico menor).

\subsubsection{Fosfolipase do tipo A2}

As fosfolipases do tipo A2 (PLA2) são encontradas na maioria dos venenos e costumam ser classificadas em dois subtipos: tipo I, mais comum em elapídeos, e tipo II, presente nos venenos de viperídeos (DUFTON \& HIDER, 1983). Baseando-se na ausência ou presença do loop pancreático (resíduos 62-67), as PLA2 tipo I, elapídicas, podem ainda ser subdivididas em Ia ou Ib. A maioria dos venenos elapídicos apresenta PLA2 Ia, embora tenha sido reportado o tipo Ib em algumas espécies como Oxyunarus scutellatus (Fohlman et al., 1977), Pseudonaja textilis (PEARSON et al., 1993), Notechis scutatus (FRANCIS et al., 1995), cobra-rei (HUANG et al., 1996), AAG23963 e AAG23964 e em cobras-corais (FRANCIS et al., 1997).

Com 120 aminoácidos e seis ou sete pontes dissulfeto, são compostas por alfa hélices e algumas estruturas em folhas beta (DUFTON \& HIDER, 1983). Estas toxinas apresentam diversas funções e especificidades. Algumas PLA2 são neurotoxinas pré- 
sinápticas, ou $\beta$-neurotoxinas com alvos específicos nas junções neuromusculares (HARRIS, 1991) para aumentar a liberação de neuromediadores. Algumas atuam como miotoxinas que despolarizam membranas celulares musculares (MEBS \& OWNBY, 1990) e levam à necrose. Acredita-se que as PLA2 possam desempenhar ações neurotóxicas por se ligarem à membrana nervosa e catalisar a hidrólise fosfolipídica com a produção de lisofosfolipídios e ácidos graxos (ROSSETTO et al., 2006).

As PLA2 encontradas aqui apresentam estrutura similar às PLA2 de veneno de outros elapídeos, ou seja, classificam-se como tipo I, particularmente do tipo Ia, pois está ausente o loop pancreático. O cluster mais abundante obtido é o MCOR0036C, com 196 clones. Esse cluster apresentou uma identidade de $100 \%$ com a sequiência de PLA2 de Micrurus corallinus previamente clonada e caracterizada por nosso grupo (DE OLIVEIRA et al., 2003). Esta sequiência apresenta na posição 49 um aminoácido aspartato altamente conservado (Asp49) e envolvido intimamente na ligação com íon metal $\mathrm{Ca}^{2+}$, que tem função essencial na atividade catalítica dessa enzima.

Realinhamos todos os clusters de PLA2 encontrados no banco, e é interessante notar que dois deles, MCOR0404S e MCOR0609S (singlets), apresentaram sequiências bastante peculiares, já que possuem inserções de 114 pb na posição 110, dentro do trecho referente à proteína madura (Figura 11). Uma observação interessante é que essa inserção corresponde exatamente aos últimos $114 \mathrm{pb}$ do íntron 4 do gene das PLA2 (FUJIMI et al., 2002). Isso significa que houve um splicing alternativo no transcrito desse clone, de forma que o íntron 4 (normalmente com $\sim 500 \mathrm{pb}$ ) não foi completamente removido e sua porção $3^{\prime}$ permaneceu no transcrito final. De fato, a inserção se inicia com o dinucleotídeo GT e se encerra com AG, justamente a seqüência canônica das junções íntron/éxon (LEWIN, 2000) (Figura 11). Além disso, a inserção de 114pb é múltipla de 3 e corresponde portanto a 38 códons codificantes (sem códons de parada). Isso permite que, após a inserção, a fase de leitura se mantenha igual à da molécula original, apresentando o mesmo C-terminal. A análise da seqüência de aminoácidos inserida não revela similaridade com domínios conhecidos. Claro que essa inserção pode ser decorrente de um erro fortuito no processo de splicing, mas o fato de não conter códons de parada nem resíduos de cisteína (o que poderia desestabilizar a estrutura) e manter a fase da tradução indicam que pode resultar em um novo produto protéico.

Sabe-se da relevância da ação fosfolipásica do tipo A2 no veneno de $M$. corallinus por ela apresentar efeito pré-sináptico neurotóxico (HARRIS, 1991 e 
RossetTo et al., 2006). E, além disso, é a segunda classe de toxinas mais abundante encontrada no banco. Por essa razão, as PLA2 são candidatos antigênicos para uma possível imunização genética.

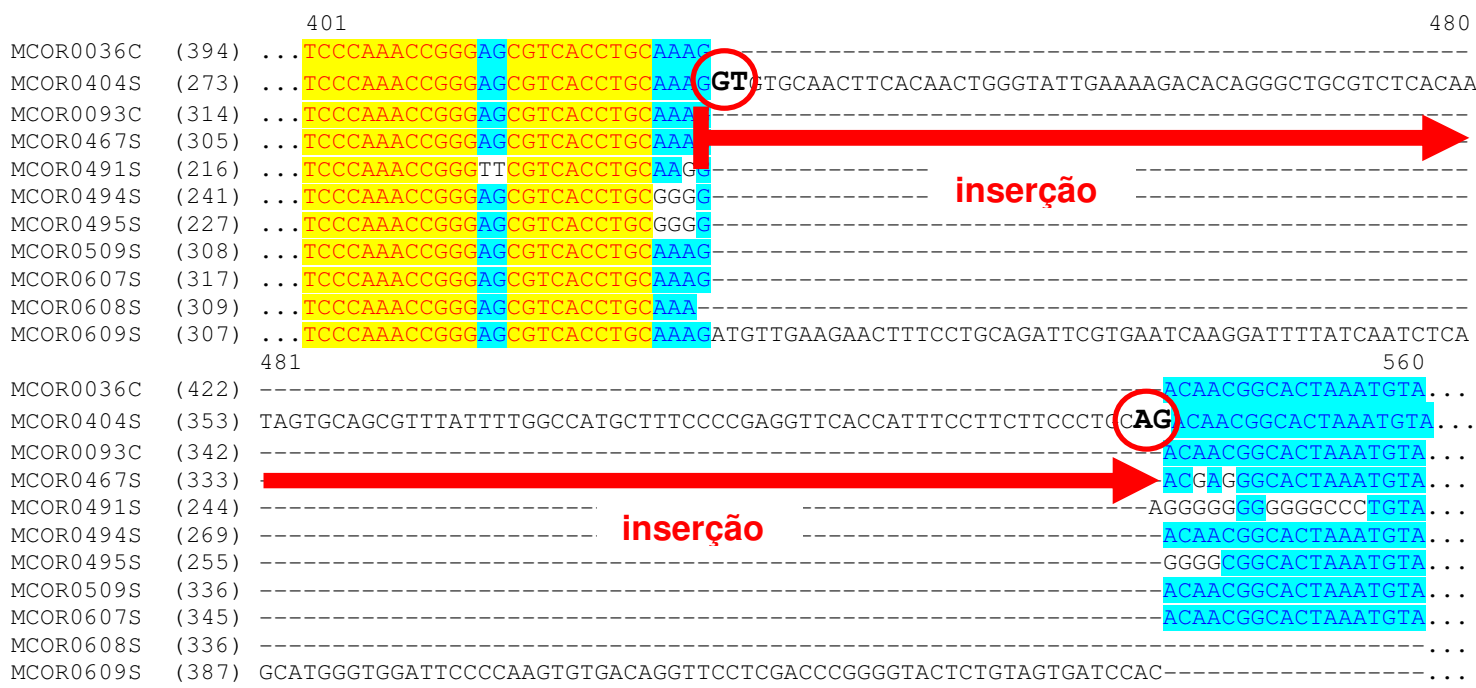

Figura 11: Alinhamento dos clusters de fosfolipase do tipo A2 obtidos por análise do transcriptoma da glândula de veneno de $M$. corallinus. Nota-se uma inserção de $114 \mathrm{pb}$ delimitada por GT e AG (seqüência canônica das junções íntron/éxon). 


\subsubsection{Lectinas do tipo $C$}

As lectinas do tipo C são proteínas não-enzimáticas presentes em venenos de serpentes de todas as Famílias. Assim como as lectinas de plantas, algumas das lectinas de veneno são capazes de se ligar a carboidratos. Na presença de $\mathrm{Ca}^{2+}$, as lectinas tipo $\mathrm{C}$ iniciam uma grande infinidade de processos biológicos, tais como adesão, aglutinação, endocitose e neutralização do patógeno. Elas podem ser divididas em sete grupos diferentes de acordo com suas características estruturais (WEIS et al., 1998). As lectinas tipo $\mathrm{C}$ que parecem ter perdido a propriedade de se ligar a carboidratos são chamadas lectinas-like, por apenas conservarem características estruturais em comum com as lectinas "verdadeiras". As lectinas de veneno podem causar agregação de hemáceas de forma dose-dependente. Recentemente, foram isoladas lectinas-like tipo C, que atuam como antagonistas e agonistas de agregação plaquetária e afetam a trombose e hemostase por inibição e ativação de receptores específicos da membrana de plaquetas (OGAwA et al., 2005). Algumas dessas lectinas podem atuar também como anticoagulantes. Bioquimicamente, as lectinas tipo C são normalmente proteínas homo ou heterodiméricas com cadeias alfa e beta relacionadas estruturalmente, e com as subunidades ligadas por pontes dissulfeto entre as cisteínas conservadas na Família. Possuem cerca de 130 aminoácidos por subunidade.

As lectinas tipo $\mathrm{C}$ têm sido bastante utilizadas como ferramenta para investigar e estudar receptores plaquetários (DU et al., 2002). Alguns inibem a função plaquetária e previnem a interação com o ligante, outros ativam as plaquetas também diretamente via receptores ou indiretamente por meio de proteínas plasmáticas. Como exemplos tem-se o echicetin, que é utilizado como receptor $\operatorname{IgM\kappa }$, e o botrocetin, que se liga ao fator von Willebrand.

A convulxina-like (Ofioluxina) foi a primeira proteína a ser identificada que age via GPVI (Glicoproteína VI) e ela tem sido bastante utilizada para o isolamento, caracterização e investigação de mecanismos sinalizadores desse importante receptor. Essa foi a primeira lectina do tipo C identificada na Família Elapidae (Du et al., 2002).

As lectinas tipo $\mathrm{C}$ encontradas aqui também são relativamente abundantes. Sessenta e cinco clones apresentaram similaridades com essas proteínas e foram agrupados em treze clusters, o que representa aproximadamente 5\% do total de proteínas expressas nesse tecido. Muitas delas correspondiam à ORFs (Open Reading Frame) completas, ilustradas na Figura 12A e alinhadas com outras lectinas tipo C de veneno. 
Sendo componentes ubíquos de venenos, porém muito diversificados em termos de estrutura-função, é interessante compreender como as diferentes lectinas tipo $\mathrm{C}$ de $M$. corallinus se encaixam na filogenia da Família. Uma análise filogenética Baesiana revela que as proteínas de veneno de serpentes se isolam num agrupamento único e distinto das lectinas fisiológicas animais (Figura 12B) Dentro do grande grupo da lectinas de veneno, nota-se claramente a distinção entre as lectinas tipo $\mathrm{C}$ verdadeiras e seus homólogos estruturais, as lectinas-like (suporte de ramo de 0,81 e 1,0 respectivamente). Todas as lectinas de $M$. corallinus se enquadram dentro do grupo das verdadeiras, juntamente com as lectinas de outros elapídeos. A única exceção é o cluster MCOR0067C (claramente distinto dos demais já no alinhamento), que é mais similar a proteínas fisiológicas curtas do grupo das litostatinas do que às lectinas de veneno (verdadeiras ou não). Recentemente, foi observada um sequiência semelhante a essa no transcriptoma da serpente B. insularis (BINS004C), que nesta filogenia realmente se agrupa com o MCOR0067C. Dessa forma, o achado de outra lectina com essas características corrobora a possibilidade de que esse seja um terceiro grupo de lectinas de veneno.

Quanto à organização dentro do ramo das lectinas verdadeiras, a maioria dos clusters se agrupa junto com a lectina de Lapemis hardwick, um elapídeo da subfamília Hydrophiinae (serpentes marinhas). Apenas um cluster, MCOR0090C, se agrupa com as lectinas verdadeiras de outros elapídeos e de viperídeos. De qualquer forma, esses componentes parecem estar bem diversificados em M. corallinus. 
MCOR0024C MCOR0 060C MCOR0 $067 \mathrm{C}$ MCOR0077C MCOR0090 MCOR0095 MCOR0292 MCOR0603Cedi AAK 4358 AAK 43586 AAB 49518 AAB 49518 ABN5 4808 BN5 4808 $\mathrm{AQ} 1515$ AAQ1515 AAS 0142 BINS $0004 \mathrm{C}$ LMUT0078C LMUT0114C LMUT $0074 \mathrm{C}$ POLF0063C POLF0 $083 \mathrm{C}$ WMER0022 WMER0022 WMER0 007 NP_114433
1

11) MGQF LLVSLGLLLVAF SLNGIGĀD---

MGRF LFVSLCLLVVAF SLNG I GAHR

(1) MGHHAFWGECLLACLSVTPLVEGIQRG-A

(1) MGQFIIVSF GLVVVALSLRGTGAD

(1) MGHFTFISLCLMPIFLSLSGAECY

(1) MGHF TF ISLCLMPIF LSLSGAEC

(1) -GKFIIVSFGLVVVAFPLRGTGAD -

(1) MGHFTF ISLCLMP IFLSLSGAECY

(1) MGHFTFIgLCLLAMFLSLSGAEC

(1) MGHFTFTGLCLLAMFLSLRGAECY

(1)

(1) MGHFTFTGLCLLAMF LSLRGAECY

(1) MGRLFASLGLIVVAFSISGTC

(1) MGRETEVSEGLLVAA

(1) MGRF IFVSFGLLVVFLSLSGTAA

(1) MGRFIFVSFGLLVVFLSLSGAKGN-

(1) MFLITCF IFGLLG-SLTWAGPSVR-

(1) MGRLIFVSFGLLVVFLSLSGTGA-

(1) MCSWLFICAFLGITFMQDVSAQTCLCAQG

(1) MGRF IFVSFGLLVVFLSLSGAAAG

(1) MGRF ILVNLGLLVVAF SLRGSEA-

(1) MGRS IFVNLGLLVVAFSLRGSEA-

(1) MGQF IVVSLGLLAVVF SLTGTGA

(1) MGOF-FLTLGLFVMSVSLKGSA

(1) MASVPHFTVFLFLACALGI GANVTRRATS

(1) MASRSMRLLLLLSCLAKTGVLG-DI IMRP

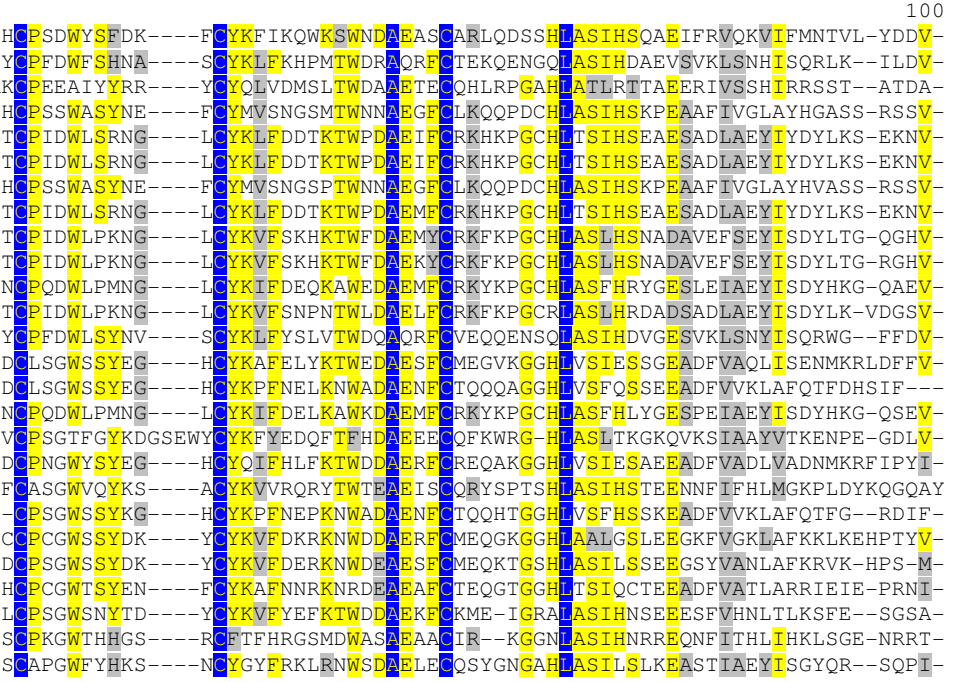

(90)

(90) WIGLNDPE---KRRAWRGSDGSRL I--YKSWMPGEPNNHASMEYCVVLS---AWSRYV

(90) WIGLNDPQ---KERIWEWTDRSSTN--YTSWNEGEPNNSWNKEYCVHLL---ASQGYI

(90) WIGLRDTK---KKYIWEWTDRSRTD--FLPWRKKQPDHFNNNEFCVEIV---NFTGYL

(90) WIGLRDTK---KKY IWEWTDRSRTD--FLPWRKNQPDHFNNNEFCVEIV---NFTGYLQ

(97) WI LWDKK---KDF SWEWIDRSCTD--YLTWDKNQPDHYEGKEFCVELV---SLTGYR

(90) WMGLRLSK---RNGIWEWSDGSNLT--YTSWKEGEPNNLFNMEFCAVLS---AGTRYL

(90) WIGLRVQGD-EKQCNSEWSDGSSVS--YENWIESES------KTCLGLE---QQTKFR

(90) WIGLRVQGD-EKQCNSEWSDGSSVS--YENWIESES------KTCLGLE---QQTKFR
(88) WMGLSNVW---NQCNWQWSNAAMLR--YKAWAE-ES------ YCVYFK---STNNK-

(90) WIGLWDKK---KDF SWEWTDRSCTD--YLSWDKNQPDHYQNKEFCVELV---SDTGYRL

(9) WIGLREVKGSSVKTRWRWTDGTRSM--YKKWSYGEPKI GHYDDPCVGLS---PASGYV

(97) WIGLRVQGE-QKKCTSKWSDGSSVS--YENWDESEL------KTCLGLE---QDTNYEK
(8)

(88) WMGLSNVW---NKCSWQWSNAAMLK--YEAWAEES-------YCVYFK---STNNK-

(90) WIGLRAQGQ-GQQCSSRWSDGSRIL--YENWHPLQS------KKCIALS---KWTEYL

(88) WIGLSNIW---NQCSWQWSDGSSLG--YEAWVEG-------PDCVMMR---LQPGE I

(89) RT LKATPOREF

(86) WIGLAR QREEQCSRKWSDGSRIG--YKKINTKY------IKKCVTLS---KVTGYQ

(86) WIGLSNVW---KKCHWEWSDQSLVD--FEAWVER-------PHCVGMR---VQPKLV
(93) WIGGNDAV---KEGMWFWSDGSKFN--YKGWKKGQPDKHVPAEHCAETN---FKGAF-

(93) WI GLHDPQ---KRQQWQWIDGAMYL--YRSWS-GKSMG--GNKHCAEMS---SNNNFLT

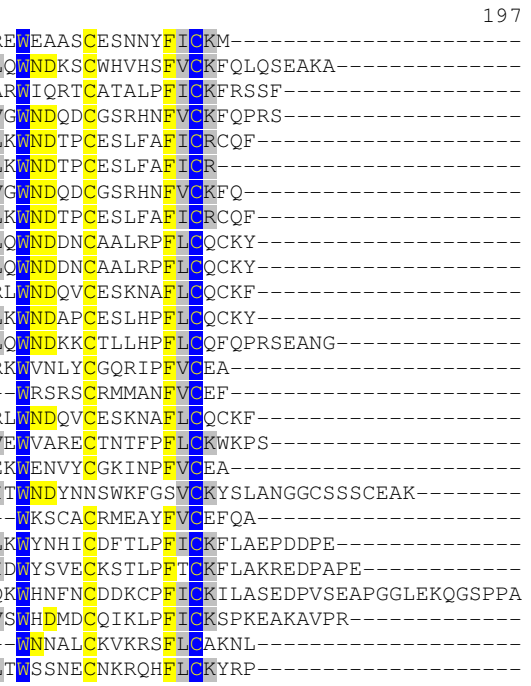




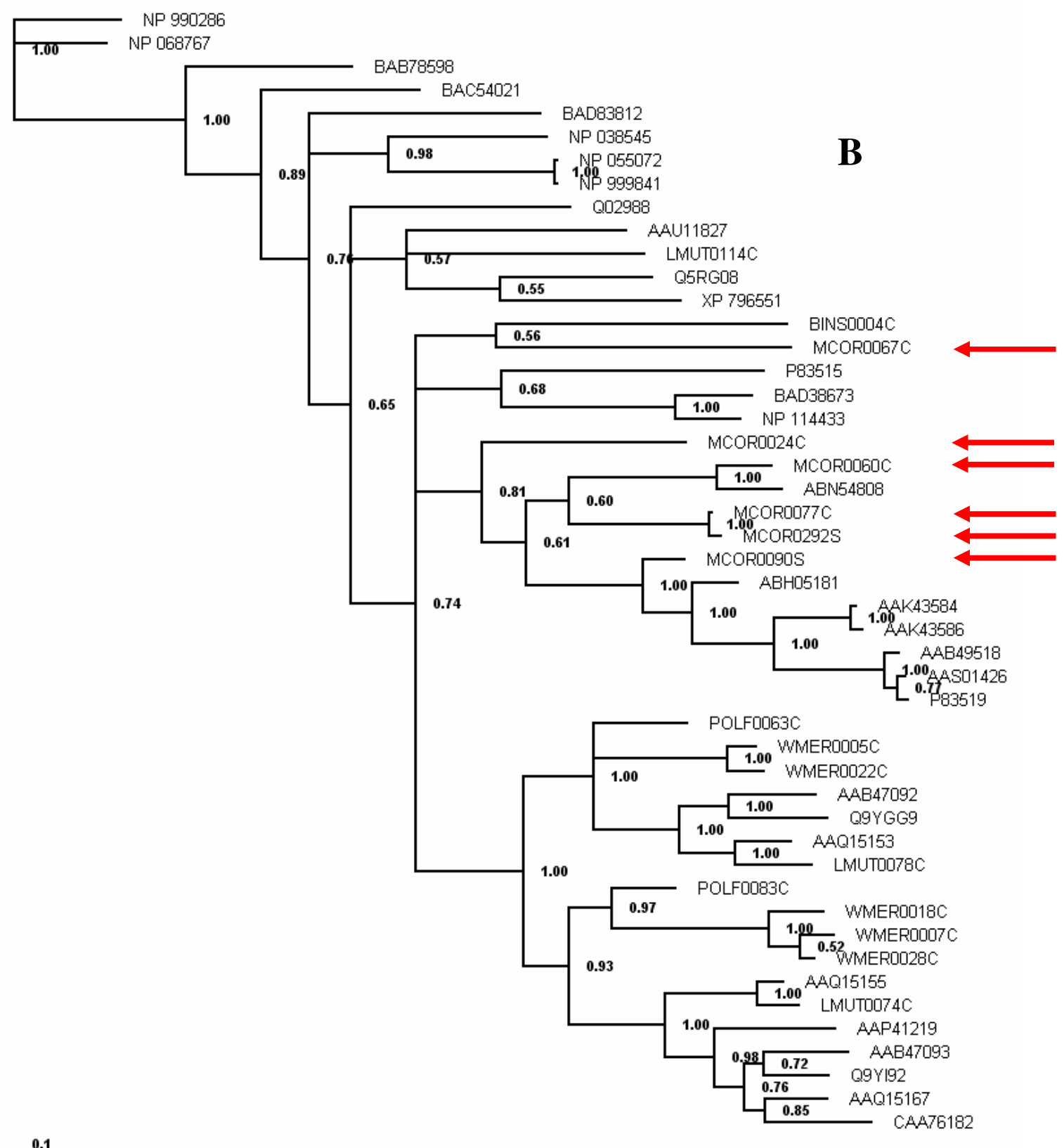

Figura 12: A) Alinhamento das lectinas do tipo $C$ e seus homólogos estruturais, as lectinas-like, juntamente com as lectinas fisiológicas animais encontradas no transcriptoma de glândulas de veneno de $M$. corallinus. B) Análise filogenética Baesiana dessas lectinas tipo $C$ (setas vermelhas indicam os clusters das lectinas tipo $\mathrm{C}$ encontradas no banco transcriptômico de glândulas de veneno de $M$. corallinus). 


\subsubsection{Peptídeo Natriurético}

O precursor do peptídeo natriurético encontrado nos elapídeos é uma forma diferenciada do precursor dos peptídeos potenciadores de bradicinina (BPP) e do peptídeo natriurético encontrado nos viperídeos. Os peptídeos natriuréticos estão presentes em muitos venenos, inclusive nos elapídicos, onde são codificados por outro tipo de precursor, sem os BPPs (SCHWEITZ et al., 1992 e Ho et al., 1997).

Três são os principais tipos de peptídeos natriuréticos encontrados: peptídeo natriurético atrial (ANP), peptídeo natriurético cerebral (BNP) e peptídeo natriurético tipo C (CNP). O peptídeo natriurético da serpente do gênero Dendroaspis (DNP) compartilha propriedades estruturais e funcionais com essas três formas. Todos apresentam efeito de vasodilatação, assim como efeitos natriuréticos. Os efeitos de vasodilatação induzido pelas três formas de peptídeos natriuréticos são mediados pela estimulação de uma guanilato ciclase específica (WoODARD et al., 2002). Um peptídeo análogo aos CNPs foi sintetizado e perfundido em rim de rato, e apresentou resposta sobre o volume urinário e excreção de $\mathrm{Na}^{2+}$ dose-depentente (Ho et al., 1997).

Encontramos cinco clusters em um total de catorze clones, que representam aproximadamente $1 \%$ de todas as proteínas expressas no banco obtido. O cDNA representante do cluster MCOR0001C (seis clones) é muito semelhante ao que foi caracterizado por Ho et al. (1995), à exceção da cisteína extra que não foi confirmada em nossa seqüência. Todos os peptídeos natriuréticos descritos até hoje apresentam uma estrutural em anel com dezessete aminoácidos atrelado por uma ponte dissulfeto, que se estende com alguns poucos aminoácidos pelo N-terminal. Já no C-terminal, os peptídeos natriuréticos do tipo $\mathrm{B}$ e $\mathrm{C}$ de mamíferos apresentam de quatro a sete aminoácidos. O peptídeo natriurético de $M$. corallinus apresenta algumas peculiaridades: a) ele apresenta uma extensão C-terminal não usual que é mais longa; e b) essas regiões flanqueadoras apresentam duas regiões homólogas de função desconhecida.

Ao realinhar os clusters entre si notamos que três clusters (MCOR0019C, MCOR0193S, MCOR0195S) apresentaram uma grande deleção de 237 pb em relação ao MCOR0001C resultando na ausência de 79 aminoácidos (Figura 13). Analisando as montagens e as ESTs individualmente, ao nível de cromatogramas, percebemos que esta deleção não deriva de artefatos do processo bioinformático e que estão até presentes em mais clones (sete no total) do que a molécula arquétipa do cluster MCOR0001C (seis clones). A fase de leitura é mantida após a deleção, de forma que o polipeptídeo 
codificado possui o peptídeo sinal, parte do prodomínio incluindo, uma parte das regiões homólogas e o restante do C-terminal. Portanto, o trecho deletado corresponde ao peptídeo natriurético maduro propriamente dito e um pouco da região flanqueadora. Diferentemente da inserção no cDNA da PLA2 (descrita na Figura 12), o trecho deletado não segue a regra GT-AG de splicing e portanto não deve se tratar de um splicing alternativo. Além disso, alguns clusters ainda apresentam inserções correspondentes a quatro resíduos (VHPE) próximas ao C-terminal.

É difícil precisar qual o real significado de uma molécula como esta, abundante, com parte dos elementos do prodomínio e do C-terminal, mas em que está ausente o CNP. Uma pista pode ser a presença, mesmo na forma deletada, de uma das regiões repetitivas, que já foi sugerida como possuindo elementos característicos de peptídeos biologicamente ativos (Ho et al., 1997). Assim, talvez esse precursor seja "desenhado" para produzir um novo peptídeo baseado nesse trecho. É interessante notar que os precursores dos BPPs/CNPs de venenos, cujas estruturas são conhecidas há algum tempo, vêm revelando novos peptídeos em suas regiões propeptídicas. GRAHAM et al., 2005, por exemplo encontraram peptídeos inibidores de bradicinina no mesmo precursor dos BPPs. Mais recentemente, WAGSTAFF et al., 2008, descreveram que a região espaçadora conservada $(\mathrm{EKW})$ de alguns precursores gera peptídeos presentes no veneno capazes de inibir as metaloproteases do próprio veneno, num suposto mecanismo de proteção contra proteólise na glândula.

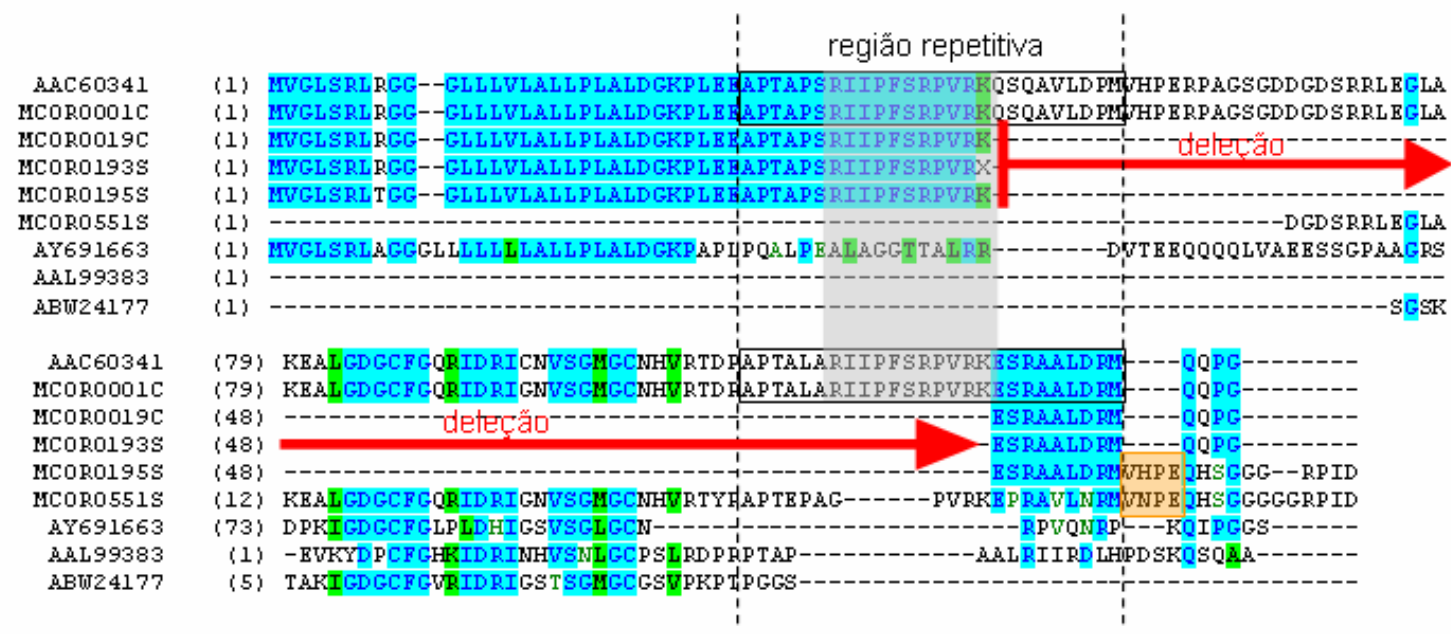

Figura 13: Alinhamento entre as seqüências de peptídeo natriurético encontrado em análise do banco de dados. A região repetitiva está delimitada entre as barras pontilhadas, com a região mais conservada destacada. 


\subsubsection{L-aminoácido oxidase}

L-aminoácido oxidases são conhecidas há muito tempo em venenos. São enzimas grandes, de $58 \mathrm{kDa}$, que atuam basicamente sobre L-aminoácidos convertendoos em cetoácidos e gerando $\mathrm{H}_{2} \mathrm{O}_{2}$, o que parece contribuir para a inibição da agregação plaquetária e lesão celular (NATHAN et al., 1982). Não foi obtido nenhum clone completo, devido provavelmente ao seu cDNA $(2,8 \mathrm{~kb})$ ser muito longo (RAIBEKAS \& MASSEY, 1998). Dois clusters, MCOR0200S e MCOR0263S, cada um contendo apenas um clone (singlet), foram encontrados no banco de M. corallinus (Figura 14). A Laminoácido oxidase já foi reportada em elapídeos, pois está depositada no banco de dados (Accession $\mathrm{n}^{0}$ AAY89682), mas não em Micrurus. Na análise desses dois clusters, notamos que os dois se sobrepõem, sendo que o MCOR0200S representa a parte correspondente a 3'UTR (posição 1368pb-1551pb), enquanto o MCOR0263S contém a parte C-terminal da região referente à proteína madura (885pb-1386pb).

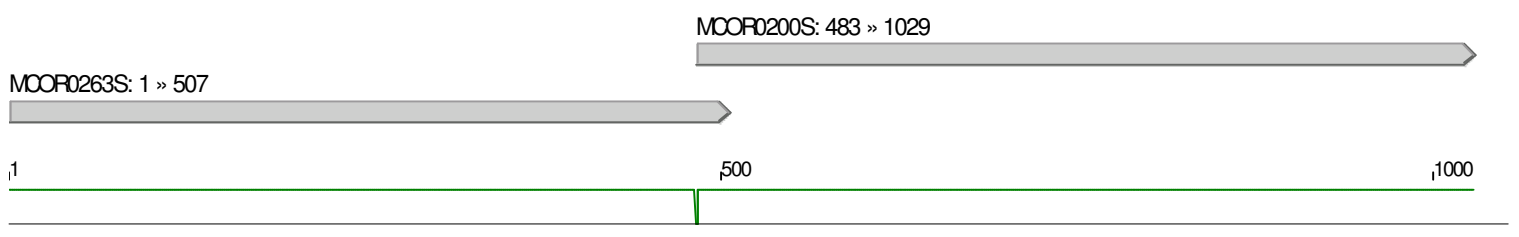

Figura 14: Dois clones encontrados no banco de dados de $M$. corallinus representando duas regiões fracamente contíguas da L-aminoácido oxidase.

\subsubsection{Inibidor do tipo Kunitz}

Nos venenos de cobras, a estrutura dos inibidores de serinoprotease do tipo Kunitz aparece na forma de dois tipos de moléculas funcionalmente distintas: os inibidores de serinoprotease não-neurotóxicos e os neurotóxicos, também chamados de dendrotoxinas, que não possuem grande ação inibitória nas proteases. Os nãoneurotóxicos são capazes de inibir a tripsina e quimiotripsina, e são comuns nas Famílias Viperidae e Elapidae (ZUPUNSKI et al., 2003). As dendrotoxinas estão presentes nos venenos de alguns elapídeos, como a mamba negra (Dendroaspis) e os kraits (Bungarus). Sua ação tóxica se dá pelo aumento da liberação de neurotransmissores, como a acetilcolina, das membranas pré-sinápticas das sinapses colinérgicas. As dendrotoxinas têm como alvo canais de potássio das membranas das células nervosas, que são bloqueados. 
Dois clusters de baixa expressão, MCOR0110C e MCOR0611S, foram encontrados no banco de dados. Ambos aparentam ser mais parecidos com os inibidores que com as neurotoxinas, já que são similares a diversos tipos de inibidores dos viperídeos, embora o grau de conservação dos dois seja baixo. Entretanto, no contexto de forte perturbação neurotóxica do veneno de $M$. corallinus tal atividade é bastante plausível, portanto mais análises ainda são necessárias para se determinar sua função exata.

\subsubsection{Metaloprotease}

As metaloproteases de veneno são normalmente agrupadas de acordo com a presença de domínios específicos. Há um domínio proteolítico caracterizado pela presença de um sítio catalítico que conserva o motivo HEXXHXXGXXH, responsável pela ligação de um íon metálico, geralmente $\mathrm{Zn}^{2+}$. Após o domínio catalítico pode haver um domínio tipo desintegrina, capaz de se ligar às integrinas de plaquetas ou de células endoteliais. A região responsável pela ligação às integrinas pode apresentar o motivo RGD (desintegrinas RGD) ou ter esta sequiência substituída por outra, como ECD (desintegrinas não-RGD), alterando sua especificidade. $\mathrm{O}$ carboxi-terminal das desintegrinas não-RGD pode ter ainda um domínio rico em cisteínas de função pouco conhecida.

A metaloprotease encontrada aqui é representada apenas por um único cluster MCOR0063C, de apenas quatro clones (1123pb). É semelhante à cobrina encontrada em Naja naja, espécie da Família Elapidae do Velho Mundo. Trata-se de um exemplar de metaloprotease do tipo P-III, ou seja, ela apresenta o domínio tipo desintegrina nãoRGD seguido de um domínio rico em cisteínas.

\subsubsection{Serinoprotease}

As serinoproteases de veneno, especialmente em viperídeos, estão relacionadas à tripsina. Essas proteínas possuem em torno de $35 \mathrm{kDa}$, apresentam seis pontes dissulfeto e quantidades variáveis de sítios de glicosilação. Estas enzimas normalmente contém doze resíduos de cisteína e uma extensão C-terminal, o que é característica das serinoproteases. As serinoproteases do veneno de cobra devem ocorrer como enzimas similares à tripsina, amplamente descrita nos viperídeos, ou como as proteínas do tipo Fator X, mais complexas, encontradas em alguns elapídeos terrestres (KINI, 2005). Recentemente, algumas enzimas similares à tripsina foram descritas na Família 
Elapidae, por exemplo, ABN72544, o que mostra que essa não é uma classificação pragmática.

A variação de substratos das diversas serinoproteases de veneno é bastante grande e muitas delas atuam sobre os elementos da cascata de coagulação.

As serinoproteases através de evoluções adaptativas aceleradas geram variantes de diversas funções (FRY et al., 2006), incluindo especificamente componentes sanguíneos de degradação e ativação que estão envolvidas na coagulação e fibrinólise (SERRANO \& MAROUN, 2005), ativando o sistema kalicreína/kinina (Hung \& CHIOU, 2001) ou afetando agregação plaquetária (LAING et al., 2005).

No transcriptoma de $M$. corallinus nós não encontramos nenhum dos tipos, apenas um único cluster parcial (MCOR0160S) que mostra mais similaridade com as serinoproteases não-venenosas dos mamíferos ( $52 \%$ de identidade) do que com as serinoproteases das serpentes ( $39 \%)$. Os maiores acertos se dão com as prostasinas de mamíferos basais, como o ornitorrinco (Monotremata) e o gambá (Metatheria). Este é um canal que ativa a protease envolvida no crescimento de células epiteliais. A porção semelhante ao MCOR0160S corresponde a uma parte do domínio da Peptidase S1, indício de que deve ocorrer atividade proteolítica. Mas, como a seqüência é parcial, não é possível determinar a presença de domínios adicionais, como o C-terminal transmembrana ou o propeptídeo. Dada a onipresença da serinoprotease nos venenos de cobra, nós incluímos este cluster entre as possíveis toxinas de M. coralinus, embora uma confirmação posterior ainda seja necessária.

\subsubsection{NGF}

Assim como seus homólogos de mamíferos que regulam diferenciação neuronal, os NGFs (Nerve Growth Factor) de veneno atuam como agonistas de baixo potencial de receptores TrkA (tirosina-quinase), ao competir pela ligação ao receptor com o NGF endógeno, influenciando no desenvolvimento de neurônios colinérgicos (MCDowALL, http://www.ebi.ac.uk/interpro/potm/2004_6/Page1.htm).

Os NGFs pertencem à família dos fatores neurotróficos e são polipeptídeos neurotróficos muito bem caracterizados. Foram os primeiros fatores neurotróficos a ser identificados como polipeptídeos que regulam manutenção e sobrevivência neuronal (KostiZA \& MEIER, 1996). Por definição, os fatores neurotróficos são proteínas solúveis endógenas que regulam sobrevivência, crescimento, plasticidade morfológica, ou síntese de proteínas para funções diferenciadas dos neurônios. 
Os NGFs apresentam um papel importante na ontogênese e regulam o desenvolvimento e manutenção de neurônios derivados de neurônios sensoriais embrionários e de células nervosas do nervo periférico simpático dos vertebrados. Recentemente, tem surgido evidências de que as NGFs têm efeito similar dentre os neurônios colinérgicos do sistema nervoso central. Apesar de induzir um típico crescimento de fibras em cultura celular, veneno de serpente e NGF humano exibem também efeitos não-neuronais, tal como indução de extravasamento plasmático e liberação de histamina de todas as células sanguíneas (KASHIMA et al., 2002).

As proteínas do tipo NGF são típicas também de muitos venenos, onde se apresentam como complexos homodiméricos associados por ligações, geralmente nãocovalentes. Os NGFs de venenos podem ser incluídos dentro do grupo das vasculotoxinas. $\mathrm{O}$ efeito desses fatores no envenenamento é provavelmente deixar o local da picada mais suscetível aos outros componentes do veneno e levar a uma distribuição ótima de substâncias que dificilmente poderiam se infiltrar no tecido alvo (Kostiza \& MEIER, 1996).

Esse componente também foi encontrado em nosso banco, porém é bem menos abundante que as demais. Talvez pelo fato de sua seqüência ser bastante longa, o único cluster obtido (MCOR0149S) é parcial, ou seja, corresponde apenas a parte da região Cterminal. Sua relevância no veneno de serpentes ainda não é muito clara.

\subsubsection{WAP}

Essa é uma classe nova de toxinas. No banco obtivemos apenas um cluster, MCOR0526S, com apenas um clone. É uma sequiência parcial, ou seja, não contém a porção do peptídeo sinal e parte da proteína madura.

A proteína WAP (Whey Acidic Proteins), ou waprina ou nawaprina (assim denominada por ter sido descrita primeiramente em Naja nigrocollis) apresenta um possível papel como inibidor de protease. É semelhante à elafina (inibidor de elastase de leucócito humano), caltrina-like (inibidor de transporte de cálcio) e a outros inibidores de protease extracelular. Por apresentar diferenças significativas em regiões importantes da molécula, nawaprina possivelmente não apresenta uma atividade de inibição da elastase e deve ter uma função diferente em venenos de serpentes (TORRES et al., 2003). Membros dessa família apresentam quatro pontes dissulfeto, das quais três estão na base da molécula. Em mamíferos, sua função parece estar relacionada à maturação espermática no epidídimo. 
O domínio WAP geralmente consiste de cinqüenta resíduos de aminoácidos, com oito resíduos de cisteína conservados formando quatro pontes dissulfeto. Apesar dos resíduos de cisteína serem conservados, os segmentos intercisteína são totalmente diferentes dos demais membros da família WAP. Além disso, o domínio WAP é encontrado em proteínas com funções divergentes, incluindo inibição $\mathrm{Na}^{+} \mathrm{K}^{+} \mathrm{ATPase}$, inibidor de proteinase com atividade antimicrobial (elafina), atividade inibitória do crescimento (ps20) e proteínas antibactericidas. A maioria das proteínas de domínio WAP reportadas estão envolvidas no sistema imune inato (NAIR et al., 2007).

\subsection{IMUNIZAÇÃO GENÉTICA}

Como discutido anteriormente, a produção de soro no Instituto Butantan é limitada, principalmente, pelo tamanho reduzido das glândulas de veneno das cobrascorais, o que acarreta uma baixa produção de veneno. Por essa razão, há uma necessidade de buscar formas alternativas para a geração de soro antielapídico. A escolha mais óbvia seria a produção de toxinas recombinantes em E. coli. Porém as 3FTx, que são as toxinas mais abundantes encontrada no veneno, apresentam muitas pontes dissulfeto, o que poderia acarretar um dobramento incorreto da proteína que leva a mudanças funcionais. Há, dessa forma, uma necessidade de se fazer o refolding da proteína (reestruturação da proteína), o que é bastante complicado, lento e custoso. Essa alternativa foi bastante explorada em projetos anteriores de nosso laboratório (PRIETO DA SILVA, 2001b), que confirmaram essas dificuldades metodológicas esperadas. Por outro lado, sistemas eucariontes como células de mamíferos ou levedura podem não render a quantidade necessária de proteína a fim de se produzir o soro. Então, experimentalmente, seria importante determinar a viabilidade de geração de resposta imune contra toxinas de cobra-coral por meio de uma outra abordagem, tal como a imunização genética, ou a vacina de DNA. Essa idéia é atual e já foi testada para venenos africanos de Echis ocellatus e Cerastes cerastes (HARRISON, 2004 e WAGSTAFF \& HARRISON, 2006). O intuito final desse projeto é justamente a imunização em cavalos, porém antes é necessário definir a prova do princípio, com a escolha dos candidatos antigênicos e pela avaliação das construções a serem utilizadas. 


\subsubsection{Escolha de candidatos antigênicos a partir do transcriptoma de M. corallinus}

Tendo em vista o padrão obtido pela análise transcriptômica, pudemos ratificar as informações contidas na literatura sobre as toxinas predominantes desse veneno e, assim, dar continuidade ao projeto.

O passo seguinte foi escolher os candidatos antigênicos para uma possível imunização alternativa. Vários tipos de toxinas foram analisados dentro do banco de ESTs (transcriptoma) de Micrurus corallinus. Essas sequiências foram comparadas com seqüências semelhantes no banco de dados e, com base na literatura, verificamos o efeito farmacológico esperado e em que contexto esse efeito estava inserido. Entre os vários critérios que podem ser adotados para orientar nossa escolha, consideramos, por exemplo:

1) cDNAs que eram abundantes (dado pelo número de clones seqüenciados), pois podem representar toxinas mais relevantes.

2) Representantes de tipos diferentes de toxinas, pois assim pode-se despertar resposta imune abrangente para todos os componentes.

3) Toxinas com formas ortólogas presentes em espécies diferentes.

4) Proteínas novas, sem função aparente, mas com peptídeo sinal para secreção.

5) cDNAs de proteínas não descritas como toxinas na literatura, mas que mediam efeitos deletérios.

Resolvemos escolher inicialmente, como validação, as proteínas sobre as quais se sabe que têm ação tóxica e são abundantes no veneno, tais como as 3FTx ( $\alpha$ neurotoxinas) e as PLA2, também conhecidas pela sua ação $\beta$-neurotóxica ou présináptica.

Pela análise das 3FTx encontradas por semelhança com o banco de dados, fizemos um alinhamento e conseguimos reunir os 37 clusters com seqüências completas (full-lengths) em diferentes lotes, conforme relatado anteriormente, dos quais escolhemos representantes de quatro grupos como candidatos a antígenos, conforme descrito a seguir.

Um grupo (representado pelo cluster MCOR0604C) é semelhante a uma seqüência peculiar, a homolog 8 (nxh8) (PRIETO DA SILVA, 2001b). Cinco clusters (um total de 44 clones) compõem o grupo, porém um cluster (MCOR0546S contendo 1 clone) foi excluído, pois apresentava muitos erros de seqüenciamento. O grupo está 
representado na Figura 15 com enfoque na seqüência escolhida como representante, pelas mesmas razões descritas acima. Da mesma forma, o clone MCAL01H08, pertencente ao cluster MCOR0604C, será considerado daqui em diante como nosso antígeno 1, referido como Atg1.$$
\text { (1) }
$$
30 40 50 60 70 86

MOOR0118C (1) MKTLLLTLVVVTIMCLDLGYTLECK ICNFKTCPTDELRRCA.SGETICYKTFWNTHRGLRIDRGCAATCPTVKPGVNI ICCKTDNCN MOOR0604C (1) MKTLLLTLVVVTIMCLDLGYTLECKICNFKTCPTDELRHCASGETICYKTFWNTHRGLRIDRGCAATCPTVKPGVNI ICCKTDNCN MCOR0605C (1) MKTLLLTLVVVT IMCLDLGYTLECK ICNFKTCPTDELRHCASGETICYKTFWNTHRGLRIDRGCAATCPTVKPGVNI ICCKTDNCN MCOR0496S (1) MKRKLLTLVVVTIMFLPLGYTLECKICNFKTCP TDELRHCASGETICYKTFWNTHRGLRIDRGCAATCPTVKPGVNI ICCKTDNCN MCOR0152S (1) ------------MCLVLGYTLNCKICNFKTCP TDELRRCASGET ICYKTFWNTHRGLRIDRGCAATCPTVKPGVNI ICCKTDNCN Consensus (1) MKTLLLTLVVVTIMCLDLGYTLECKICNEKTCPTDELRHCASGETICYKTEWNTHRGLRIDRGCAATCPTVKPGVNI ICCKTDNCN

Figura 15: Alinhamento dos clusters que representam o grupo homolog 8 (nxh8). O cluster MCOR0604C (Atg1) foi o escolhido para representar todo o grupo e é idêntico à seqüência nxh8 (Accession nํsp|P58370|NXAH8_MICCO).

Um segundo grupo (representado pelo cluster MCOR0599C) é semelhante às neurotoxinas homólogas nxh1, nxh3 e nxh7 (Ho et al., 1995). Os quinze clusters pertencentes a esse grupo somam 126 clones e foram alinhados, sendo representados na Figura 16 com enfoque na sequiência do cluster escolhido como representante, por estar entre os mais abundantes e possuir a seqüência mais consensual do grupo. Dessa forma, o clone MCAL07D03, pertencente ao cluster MCOR0599C, será considerado daqui em diante como nosso antígeno 2, referido como Atg2.

(1) 1 10 20 30 40 50 60 MCOR0117C (1)-MKTLLLTLVVVTIVCLDFGYTI ICYKRHASDSQTKTCLSGICYKKYTRGRYNPEMGCGCPQSGRGVDVDCCMRDKCNG MCOR0444S (1) -MKTLLLTLVETDIVCLDFGYTI ICYKRHA.SDSQTKTCLSGICYKKYTRGRYNPEMGCGCPQSGRGVDVDCCMRDKCNG MCOR0543S (1) -MKTLLLTLVVVTIVCLDFGYTIVCYKRHASDSQTTTCLSGICYKKITRGISRPEMGCGCPQSSRGVKVECCMRDKCNG MOOR0597C (1)-MKTLLLTLVVVTIVCLDFGYTIVCYKRHASDSQTTTCLSGICYKKITRGISRPEMGCGCPQSSRGVKVECCMRDKCNG MCOR0598C (1) -MKTLLLTLVVVTIVCLDFGYTIVCYKRHASDSQTTTCLSGICYKKITRGSSRPEMGCGCPOSSRGVKVECCMRDKCNG MCOR0483S (1) MTKTLLLTLVVVTIVCLDFGYTIVCYKRHASDSQTTTCLSGICYKKITRGSSRPEMGCGCPQSSRGVKVDCCMRDKCNG MCOR0584S (1) -MKTLLLTLVVVTIVCLDFGYTIVCYKRHASDSQTTTCLSGICYKKITRGSSRPEMGCGCPQSSRGVKVDCCMRDKCNG MOOR0004C (1)-MKTLLLTLVVVTIVCLDFGYTIVCYKRHASDSOTTTCLSGICYKKITRGSSRPEMGCGCPOSSRGVKVDCCMRDKCNG MOOR0599C (1)-MKTLLLITLVVVTTIVCLDFGYTTVCYKRHASD SOTTTCLLSGTCYKKTTRGSSRPEMGCGCPOSS SRGVKVDCCMRDKCNG MCOR0106C (1) -MKTLLLTLVVVTIVCLDFGYTIVCYKRHASDSQTTTCLSGICYKKITRGSSRPEMGCGCPQSSRGVKVDCCMRDKCNG MCOR0476S (1) -MKTLLLTLVVVTIVCLDFGYTIVCYKRHASDSQTITCLSGICYKKITRGSSRPEMGCGCPQSSRGVKVDCCMRDKCNG MCOR0600C (1) -MKTLLLTLVVVTIVCLDFGYTIVCYKRHASDSQTTTCLSGICYKKITRGSSRPEMGCGCPOSSRGVKVDCCMRDKCNG MCOR0568S (1) -MKTLLLTLVVVTIVCLDFGYTIVCYKRHASDSQTTTCLSGICYKKITRGSSRPEMGCGCPQSSRGVKVDCCMRDKCNG MCOR0540S (1) -MKTLLLTLVVVTIVCLDFGYTIVCYKRHASDSQTTTCLSGICYKKITRGSSRPEMGCGCPQSSRGVKVDCCMRDKCNG MCOR0557S (1) -MKTLLLTLVVVTIVCLDFGYTIVCYKRHASDSQTTTCLSGICYKKITRGSSRPEMGCGCPQSSRGVKVDCCMRDKCNG Consensus (1) MKTLLLTLVVVTIVCLDFGYTIVCYKRHASDSQTTTCLSGICYKKITRGSSRPEMGCGCPQSSRGVKVDCCMRDKCNG

Figura 16: Alinhamento dos clusters que representam o grupo nos quais incluem nxh1, nxh3 e nxh7. O cluster MCOR0599C (Atg2) foi o escolhido para representar todo o grupo e é idêntico à seqüência nxh7 (Accession nํsp|Q9PRI1|NXAH7_MICCO). 
Estes dois tipos de neurotoxinas eram os mais abundantes (Figuras 15 e 16) e, portanto, os candidatos eram mais evidentes. Entretanto, os outros clusters de 3FTx correspondem a formas bastante diferenciadas e não possuem identidade significativa com qualquer outra possível neurotoxina elapídica depositada nos bancos de dados (apresentam apenas um padrão de conservação dos resíduos importantes do grupo). Foi feito um alinhamento de todas essas sequiências diferentes de neurotoxinas (quinze clusters), que foram denominadas "outras neurotoxinas". Deste alinhamento, fomos excluindo as proteínas que representavam isoformas semelhantes umas das outras até que ficassem apenas as formas mais diferenciadas. Sete clusters foram então omitidos, e restou somente um representante de cada tipo (Figura 17). Dentro desse conjunto, destacam-se dois tipos mais abundantes: um composto por 29 clones (representado pelo cluster MCOR0039C) e outro com 27 clones (representado pelo cluster MCOR0100C). Esses dois clusters, destacados na Figura 17, foram selecionados como candidatos antigênicos por serem abundantes e diferentes das duas seqüências já conhecidas de Micrurus descritas anteriormente, e foram denominados, respectivamente, Atg3 e Atg4.

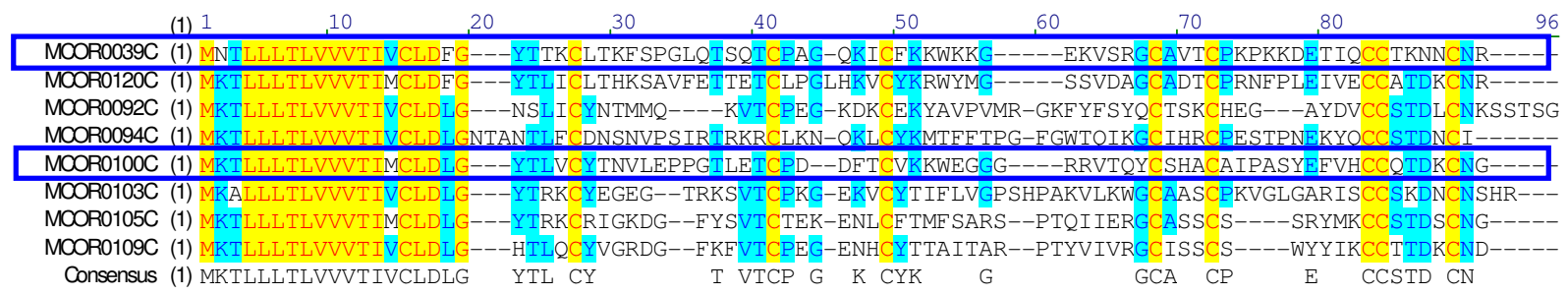

Figura 17: Alinhamentos dos clusters representantes do grupo "outras neurotoxinas". Em destaque estão os clusters escolhidos como candidatos antigênicos (Atg3 e Atg4).

A Figura 18 representa o alinhamento das quatro diferentes 3FTx que foram selecionadas como candidatos.

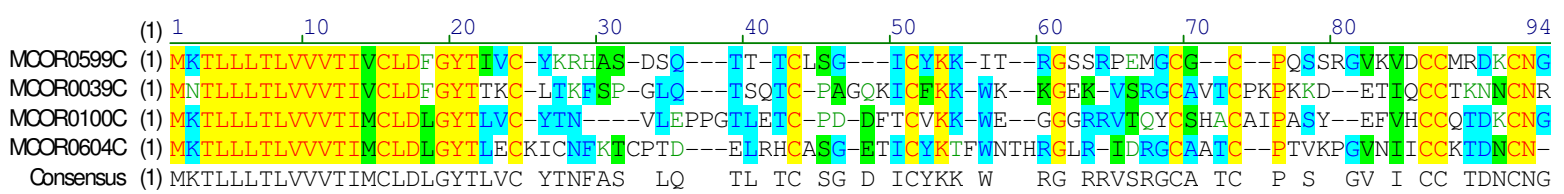

Figura 18: Alinhamento dos principais candidatos de proteínas de três dígitos escolhidos a partir do transcriptoma de M. corallinus. 
O quinto candidato escolhido é o cluster MCOR0036C, representando o cluster mais abundante obtido com 196 clones de possíveis PLA2. Como mostrado anteriormente, os outros clusters menos abundantes diferenciam-se deste pela presença de deleções e inserções. A Figura 19 representa o cluster escolhido como candidato da PLA2, considerado daqui em diante como Atg5 (Antígeno 5).

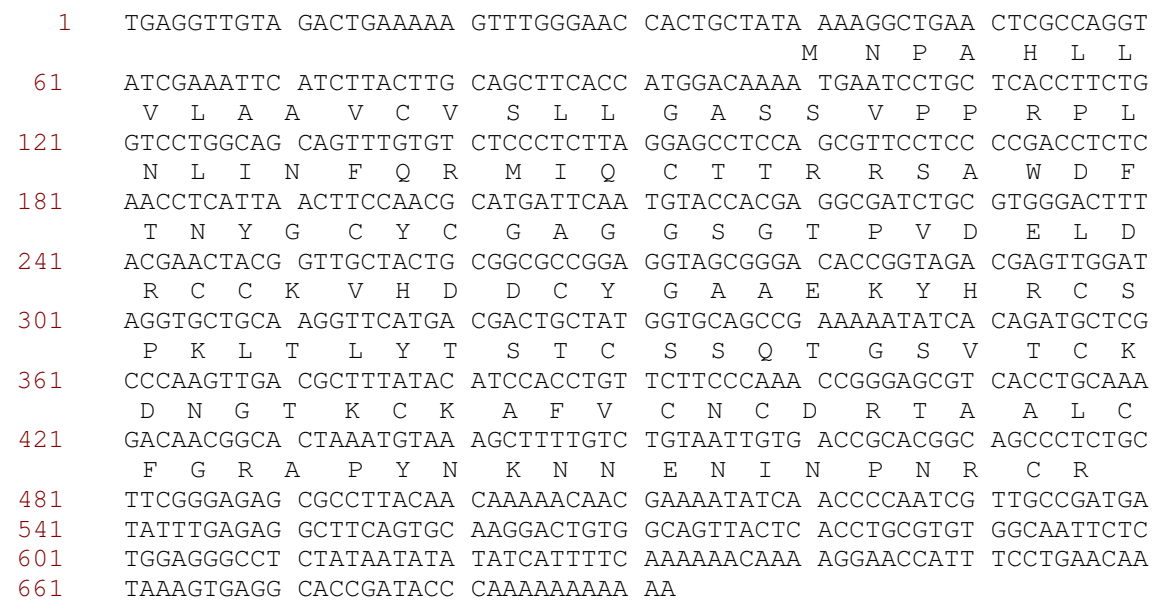

Figura 19: Candidato selecionado para representar as fosfolipases do tipo A2 (PLA2) (BINS0036C - 196 clones).

Estes cinco candidatos destacados acima foram preparados para avaliação de seus potenciais imunogênicos.

\subsubsection{Clonagem dos candidatos antigênicos para imunização genética}

Seguimos a estratégia apresentada na Figura 4 para clonagem de todos os candidatos. Entretanto, o andamento das clonagens foi diferenciado em cada caso. A seguir apresentamos caso a caso o resultado das clonagens.

\subsubsection{Antígeno 1 (Atg1)}

Todas as etapas foram realizadas com sucesso. A Figura 20A abaixo apresenta o PCR dos dois clones representantes do grupo: MCAL01H08 e MCAL09C06. Os dois clones foram amplificados com os primers específicos (Neuro1F e Neuro1R). A banda referente ao clone MCAL01H08 foi recortada e purificada. Esse inserto foi ligado ao vetor pGEM-T e transformado em bactérias DH5 $\alpha$. A presença de colônias positivas foi 
verificada pelo screening por PCR com os primers M13F e o Neuro1R. Dessa forma, dentre os seis testados, quatro foram positivos (MCAL01H08.3, MCAL01H08.4, MCAL01H08.5 e MCAL01H08.6). Foi escolhido o clone MCAL01H08.5 para ser inserido no segundo vetor. A etapa seguinte é a digestão com enzimas de restrição BamHI e EcoRI. A digestão está representada na Figura 20B. O fragmento exposto foi recortado e purificado.
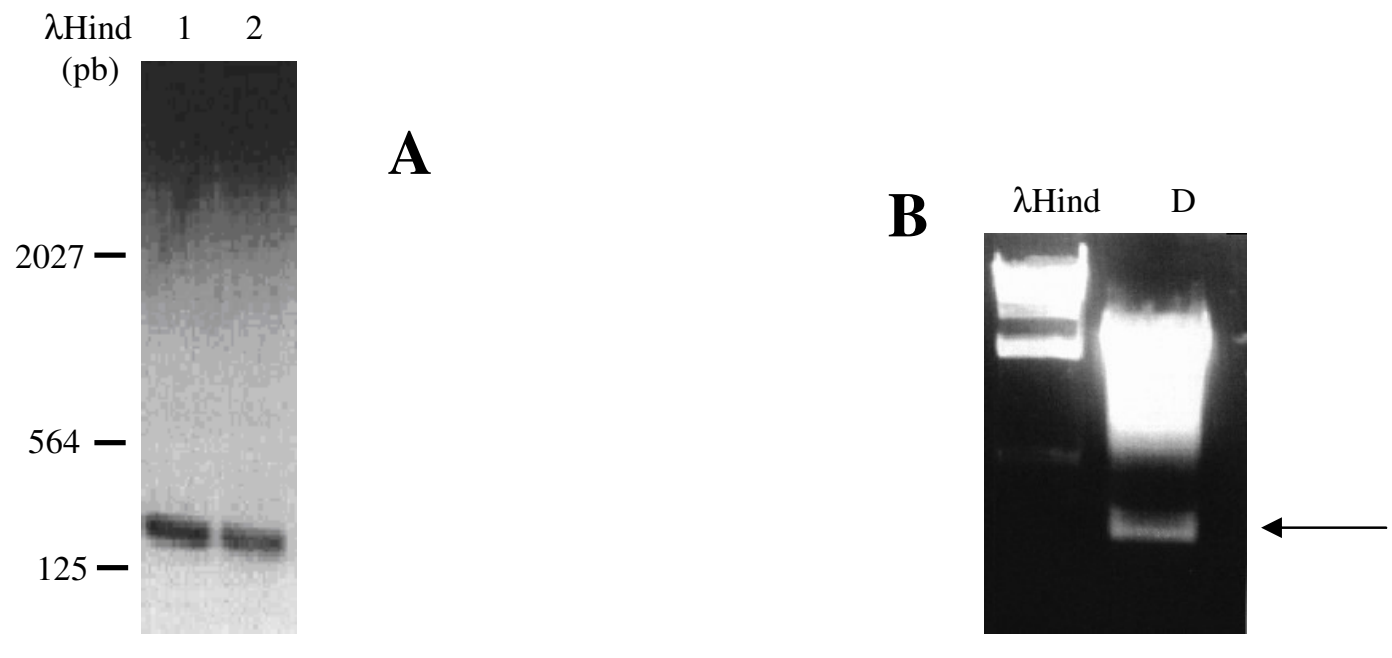

Figura 20: A) PCRs dos clones MCAL01H08 e MCAL09C06, os dois clones representantes do grupo Atg1. B) Digestão do clone MCAL01H08.5 escolhido para representar o Atg1. Nesta figura está representado apenas o clone digerido (D). A imagem encontra-se superexposta para facilitar a visualização da banda de baixa massa molecular.

Após a digestão, foi feita uma segunda ligação com o vetor pSecTag2A. A ligação foi transformada. O screening por PCR é realizado para averiguar a presença de colônias positivas com o fragmento. Para cada clone positivo foi atribuído um terceiro número: MCAL01H08.5.1, MCAL01H08.5.2, MCAL01H08.5.3, MCAL01H08.5.3, MCAL01H08.5.5, como podemos observar na Figura 21. Os clones foram confirmados por seqüenciamento. 


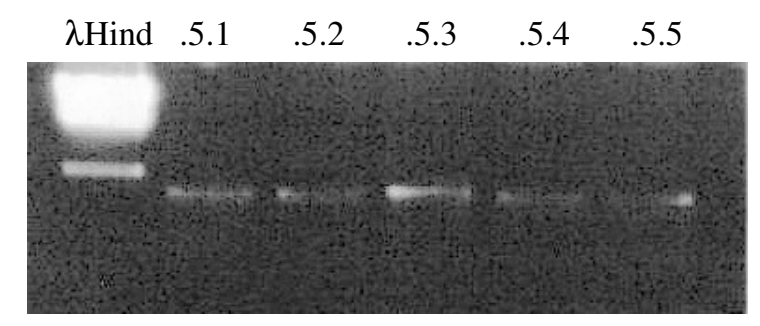

Figura 21: Screening por PCR (pSecTagA2 + fragmento/clone 1.5). Nessa figura estão presentes cinco clones do Atg1.

\subsubsection{Antígeno 2 (Atg2)}

Os clones representantes desse grupo de candidatos antigênicos, MCAL07D03 e MCAL07H04, foram amplificados por PCR. O resultado está apresentado na Figura 22A. A banda referente à amplificação do MCAL07D03 foi recortada, purificada e ligada ao pGEM-T, que foi transformado. Foi escolhido o clone MCAL07D03.2 para dar continuidade às clonagens. A digestão do clone MCAL07D03.2 está representada na Figura 22B. O fragmento produzido foi recortado, purificado e ligado no segundo vetor, o pSecTag2A. O screening por PCR (clone ligado ao vetor pSecTag2A) está representado pela Figura 23, e o clone escolhido MCAL07D03.2 foi confirmado por seqüenciamento.
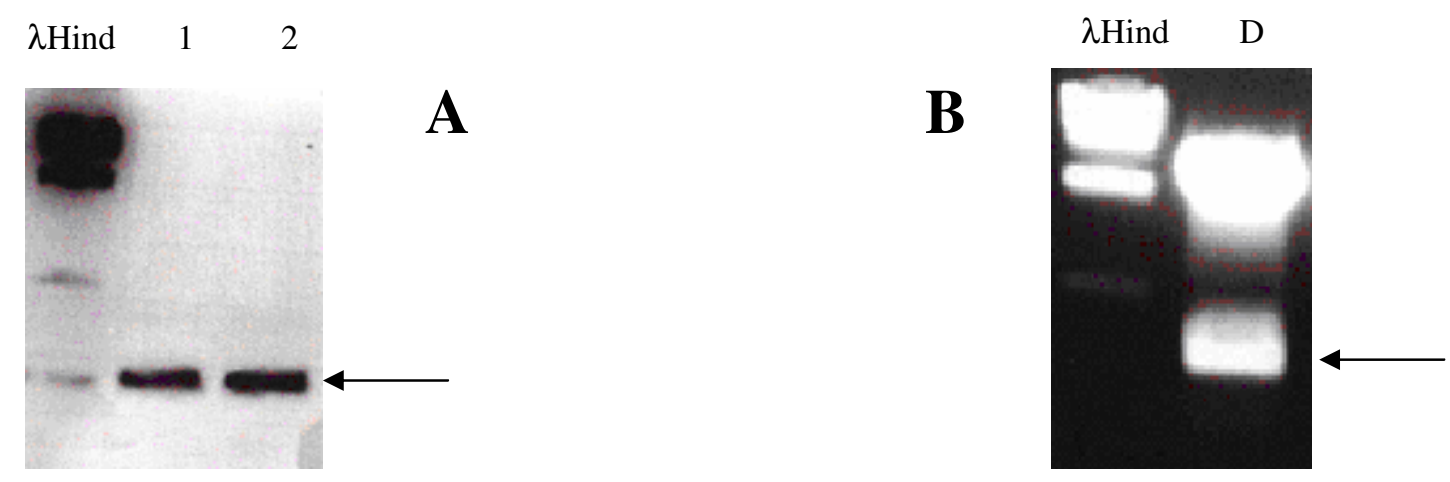

Figura 22: A) PCRs dos clones MCAL07D03 (1) e MCAL07H04, (2) os dois clones representantes do Atg2. Foi escolhido o MCAL07D03 para dar continuidade às clonagens. $B$ ) Digestão do clone MCAL07D03.2 escolhido para representar o Atg2. Nesta figura está representado apenas o clone digerido (D). O fragmento proveniente da digestão (seta) foi recortado e purificado. 


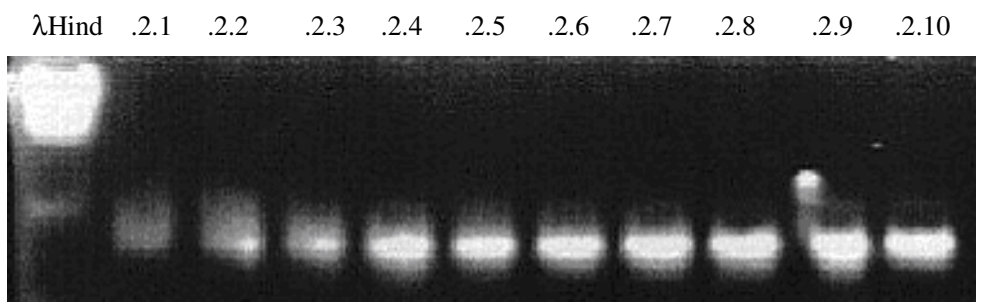

Figura 23: Screening por PCR (pSecTagA2 + fragmento/clone MCAL07D03.2). Nessa figura estão presentes dez clones do grupo Atg2.

\subsubsection{Antígeno 3 (Atg3)}

Esse grupo, representado pelos clones MCAH05B08 e MCAL06A11, apresentou algumas dificuldades na amplificação. Foram feitas numerosas tentativas (dados não mostrados) com ambos os clones, com diferentes condições de PCR e de produto de amplificação, até que com uma temperatura de anelamento de apenas $40^{\circ} \mathrm{C}$ conseguimos uma amplificação fraca (Figura 24A). A banda referente ao candidato foi recortada, purificada e ligada ao pGEM-T. A digestão com BamHI e EcoRI resultou na banda apresentada na Figura 24B. Apesar de a digestão não ter sido muito evidente, foi possível recortar a banda e purificá-la. O fragmento foi ligado no pSecTag2A e transformado em DH5 $\alpha$. Um único clone positivo (MCAH05B08.1) foi selecionado por screening e confirmado por seqüenciamento.

$\lambda$ Hind 5

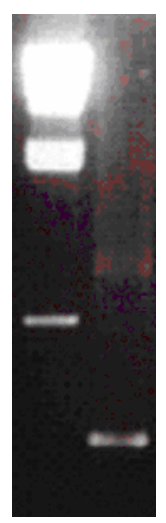

A

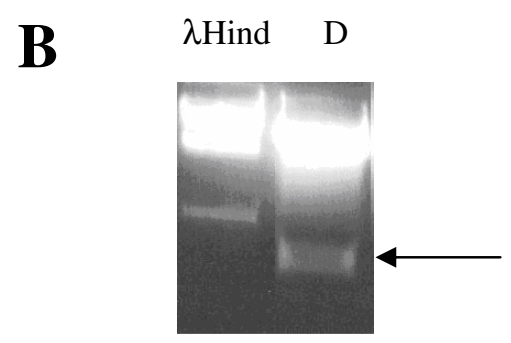

Figura 24: A) Amplificação bem sucedida do clone MCAH05B08 (Atg3). B) Digestão do clone MCAH05B08.1 escolhido para representar o grupo Atg3. Nesta figura está representado apenas o clone digerido (D). O fragmento proveniente da digestão (seta) foi recortado e purificado. 


\subsubsection{Antígeno 4 (Atg4)}

Este grupo, representado pelos clones MCAL07E03 e MCAL09G04, apresentou um padrão de amplificação inespecífico, com tamanhos não esperados. Testamos os primers individualmente e verificamos que o problema estava no primer reverse Neuro4R encomendado, que veio com defeito, pois não era capaz de amplificar nenhum produto, mesmo quando combinado com primers forward universais ligados ao vetor (teste não apresentado).

Foi feito um novo desenho do primer Neuro4R. Com o novo primer, a amplificação ocorreu sem problemas, como pode ser verificado na Figura 25A. A banda amplificada do clone MCAL07E03 foi ligada ao pGEM-T e transformada em DH5 $\alpha$. Foi escolhido o clone MCAL07E03.5 para dar continuidade às clonagens. O clone MCAL07E03.5 foi digerido com as enzimas BamHI e EcoRI, como realizado nos outros experimentos citados acima. A Figura 25B apresenta a digestão e o fragmento proveniente dessa digestão.

$\lambda$ Hind $\quad 1 \quad 2$

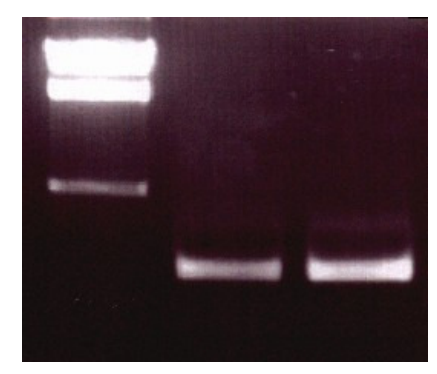

\section{A}

Figura 25: A) PCRs dos clones MCAL07E03 (1) e MCAL09G04 (2), os dois clones representantes do Atg4. Essa figura representa a amplificação bem sucedida com utilização do novo primer Neuro4R. B) Digestão do clone MCAL07E03.5. Nesta figura está representado apenas o clone digerido (D). O fragmento proveniente da digestão (seta) foi recortado e purificado

O fragmento purificado foi ligado no vetor pSecTag2A e transformado em bactérias DH5 $\alpha$. Após o screening por PCR, os clones foram confirmados por seqüenciamento. 


\subsubsection{Antígeno 5 (Atg5)}

No caso do Atg5, os clones que o representam são MCAL09A06 e MCAL06A06. Os dois clones foram amplificados com os primers específicos (PLA1F e PLA1R). Na Figura 26A estão representadas, em gel de agarose 1,5\%, as duas amplificações realizadas para esse grupo. A banda referente ao clone MCAL09A06 foi recortada, purificada, ligada ao vetor pGEM-T, e este transformado em bactérias E. coli DH5 $\alpha$. A presença de colônias positivas foi ratificada pelo screening por PCR. Para cada colônia positiva foi atribuído um número. Dessa forma, o clone 9 apresentou quatro novos subclones (MCAL09A06.1 MCAL09A06.2, MCAL09A06.3, MCAL09A06.4). Foi escolhido o clone MCAL09A06.1 para ser inserido no segundo vetor. A etapa seguinte foi a digestão com enzimas de restrição BamHI e EcoRI, a fim de tornar as extremidades coesivas para encaixe no segundo vetor. A digestão está representada na Figura 26B.

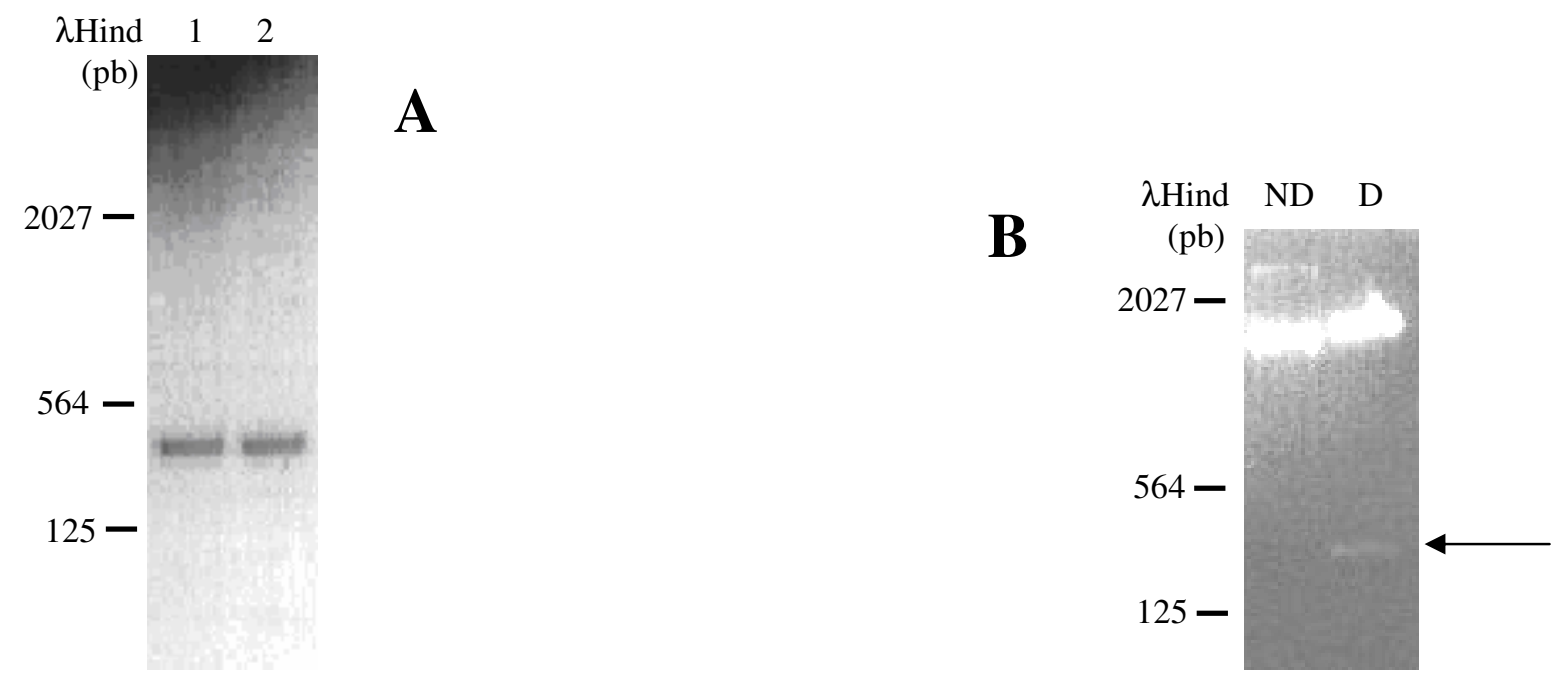

Figura 26: A) PCRs dos clones MCAL09A06 (1) e MCAL06A06 (2), os dois clones representantes do Atg5. B) Digestão do clone MCAL09A06.1 escolhido para representar o Atg5. Estão representados o clone não digerido (ND) e o clone digerido (D) com o fragmento liberado (seta).

Por conseguinte, foi realizada a ligação com o vetor pSecTag2A e a transformação em E. coli. O screening por PCR foi realizado para averiguar a presença de colônias positivas com o fragmento. Para cada clone positivo foi atribuído um terceiro número, como podemos observar na Figura 27. Os clones positivos foram 
MCAL09A06.1.4 e confirmados por seqüenciamento.

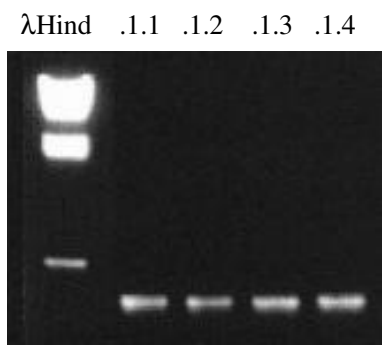

Figura 27: Screening por PCR (pSecTagA2 + fragmento/clone MCAL09A06.1). Nessa figura estão presentes quatro clones do Atg5.

A fim de se aumentar consideravelmente a quantidade de DNA dos cinco candidatos antigênicos, foram feitas maxipreps ou grandes preparações das amostras dos candidatos obtidos após a clonagem. Esse procedimento é necessário, pois se sabe que, no caso de vacinas de DNA, grandes quantidades de DNA são utilizadas para se injetar em animais (camundongos), especialmente em injeções intramusculares.

Após a eluição em $300 \mu \mathrm{L}$, foram feitas quantificações por meio do espectrofotômetro e detecção da pureza (DO 260/280).

\subsubsection{Transfecção preliminar de clones em células eucarióticas e Western-Blot}

Realizamos transfecções de algumas construções com as células do tipo COS07, que são mais utilizadas para transfecções do tipo transiente. Essa etapa foi realizada a fim de se verificar o funcionamento correto do sistema de expressão antes de dar início às imunizações genéticas.

Primeiramente, testou-se o Atg1. Pelo resultado do Western Blot com o soro antielapídico, não foi possível verificar bandas imunoreativas nas amostras de extrato celular e de meio de cultura, indicando que não deveria haver proteína recombinante sendo expressa/secretada (Figura 28). O controle positivo de veneno bruto de $M$. corallinus apresentou marcação.

Foram realizados outros experimentos de transfecção em células eucariontes do tipo COS-07 que não obtiveram resultados satisfatórios e, dessa forma, não estão representadas neste trabalho. 


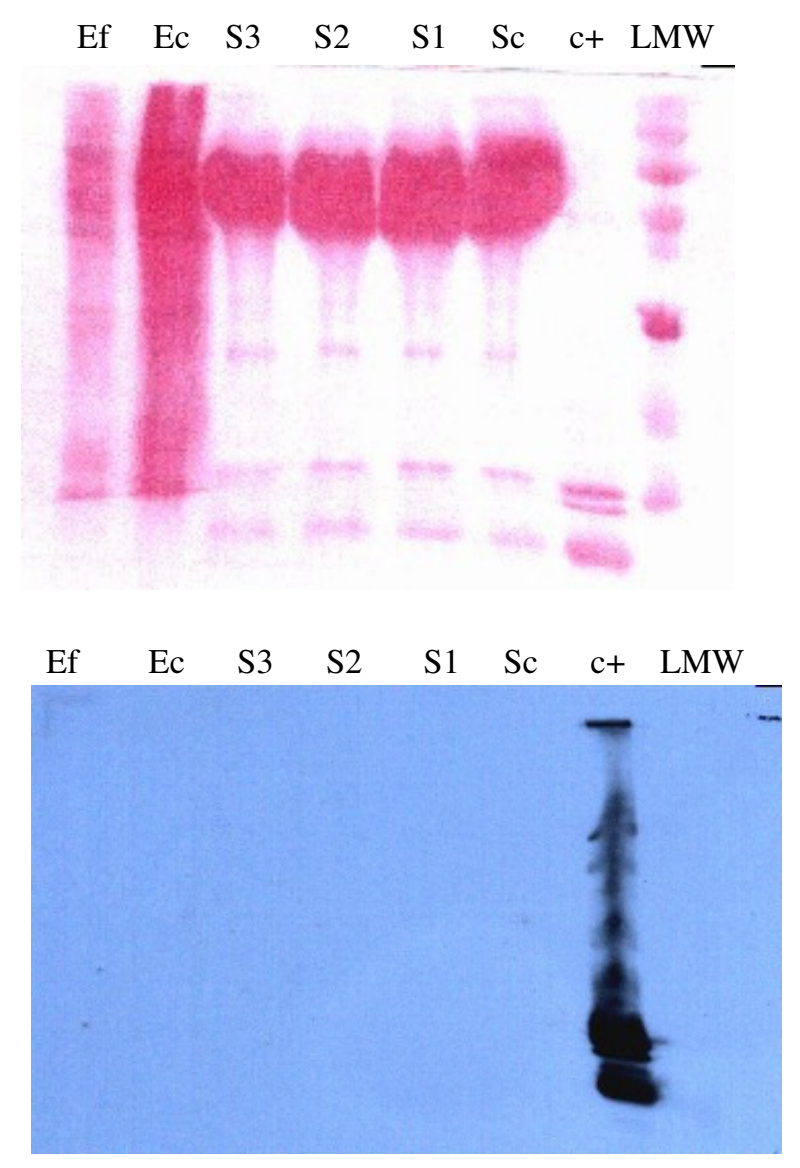

Figura 28: SDS-PAGE contendo amostras das três coletas de sobrenadante e do extrato de células. Na primeira figura encontra-se a membrana de transferência, que mostra a proteína total corada com Ponceau S. A segunda figura é o resultado do Western blot revelado com antiveneno de Micrurus corallinus (anti-corallinus) extraído de cavalo. c+ - controle positivo (no caso, veneno de Micrurus corallinus), Sc - Sobrenadante/ controle, S1 -

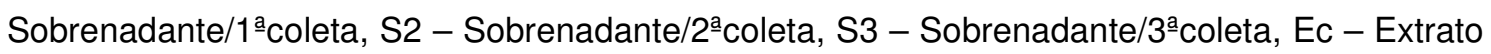
de células/ controle, Ef - Extrato de células/final.

Porém, apesar de as transfecções realizadas em células COS-07 não terem resultados satisfatórios, mais um experimento foi realizado com o sobrenadante e extrato de células provenientes da transfecção dos antígenos Atg1 e Atg4. Como não obtivemos resultados positivos com as transfecções, resolvemos mudar o anticorpo primário utilizado para um anticorpo mais específico do que o anti-corallinus usado anteriormente. A membrana foi revelada com anticorpo anti-cmyc. Neste caso, o controle positivo é uma proteína HEK $(80 \mathrm{kDa})$ que contém o epítopo c-myc. O SDSPAGE foi realizado com as amostras de sobrenadante de cada um dos antígenos (Atg1 e Atg4), coletadas 72 horas após a transfecção. Os extratos de células apresentados são os 
extratos finais de cada uma das transfecções. Estes resultados estão apresentados abaixo na Figura 29.
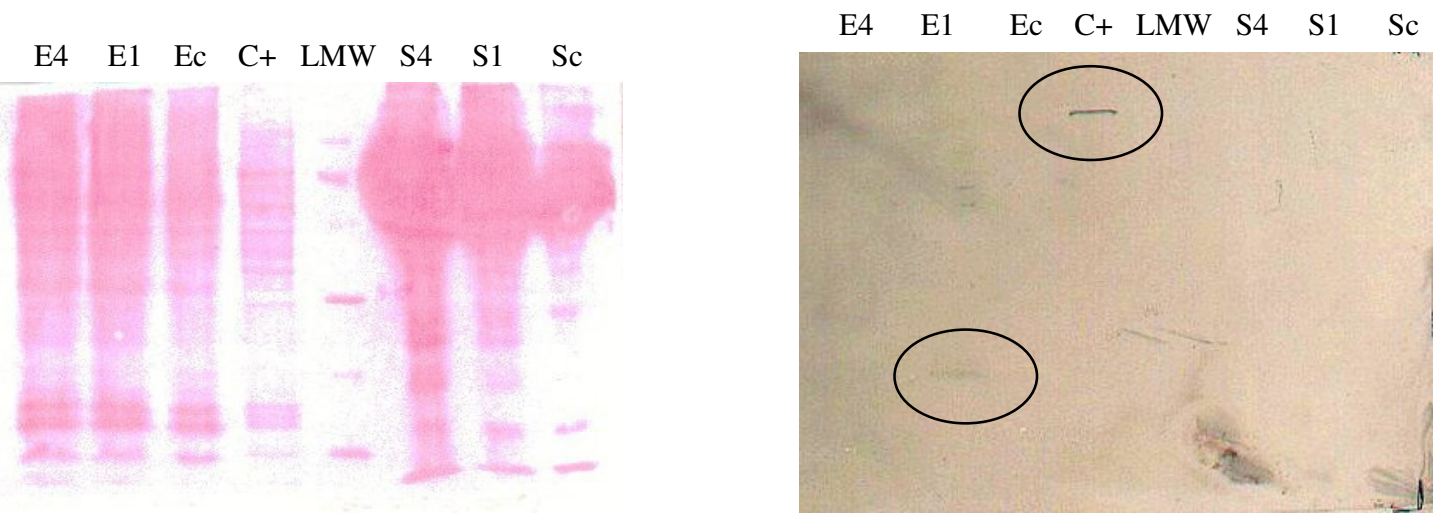

Figura 29: SDS-PAGE contendo amostras das três coletas de sobrenadante e do extrato de células. Na primeira figura encontra-se a membrana de transferência, que mostra a proteína total corada com Ponceau S. A segunda figura é o resultado do Western Blot revelado com anti-cmyc, c+ - controle positivo (no caso, proteína HEK), Sc - Sobrenadante/ controle, S1 Sobrenadante/Atg1, S4 - Sobrenadante/Atg4, Ec - Extrato de células/ controle, E1 - Extrato de células/final do Atg1, E4 - Extrato de células/final do Atg4, LMW - padrão de peso molecular.

Mesmo não evidente, pode se notar que o controle positivo acendeu e, juntamente com ele, uma pequena mancha no extrato de células da transfecção do Atg1 pode ser percebida. Esse é o resultado obtido mais próximo do resultado esperado.

Outros tipos de células COS foram utilizadas para as transfecções, pois poderia ser devido ao tipo celular a ausëncia de expressão em células eucariontes.

Também foi utilizado um controle positivo de GFP (Green Fluorescent Protein) durante algumas transfecções, a fim de que pudéssemos controlar as condições de expressão de forma igualitária para todas as células transfectadas. Quando ocorria a expressão de GFP, as transfecções realizadas estariam sob as mesmas condições. Esse controle foi bem sucedido em todos os experimentos realizados com ele, pela observação da coloração esverdeada no microscópio eletrônico.

A partir dos resultados obtidos pode-se concluir que o experimento de avaliação da expressão em cultura de células não foi bem sucedido. Foram realizadas muitas tentativas de transfecções em células eucariontes, que apresentaram resultados inconclusivos, principalmente pelos controles positivos de que dispúnhamos, que em muitos casos não reagiram. O tipo de células COS utilizadas nas transfecções, assim como o anticorpo primário utilizado, foi modificado a fim de se tentar abranger o maior número de condições possíveis para um resultado mais satisfatório. 
Tendo em vista que os resultados não foram satisfatórios para assegurar a expressão ou não dos candidatos antigênicos, decidimos investir diretamente na imunização em camundongos, o nosso objetivo final.

\subsubsection{Expressão e purificação das proteínas recombinantes}

Embora a vacina de DNA fosse nosso objetivo, necessitávamos dos antígenos para avaliar as imunizações. Tendo em vista que a melhor forma de analisar o resultado da imunização seria o teste de ELISA com o coating feito a partir da proteína purificada de cada candidato antigênico, optamos por expressar em E. coli e purificar essas proteínas. Para isso, utilizamos clonagens já feitas anteriormente por pesquisadores que trabalharam no nosso laboratório (PRIETO DA SILVA, 2001b e DE OliveIRA et al., 2003), uma vez que três dos candidatos antigênicos escolhidos (Atg1, Atg2 e Atg5) já haviam sido estudados anteriormente, porém, de acordo com a bioquímica tradicional de clonagem, expressão e purificação das proteínas recombinantes.

Dessa forma, essas clonagens feitas no vetor $p R S E T$ foram recuperadas, transformadas e seqüenciadas novamente. Os antígenos apresentavam denominações diferentes: $\operatorname{Atg} 1=\mathrm{V} 8, \operatorname{Atg} 2=\mathrm{V} 1$ e Atg5 = V2. Com as seqüências analisadas, iniciamos o processo de expressão, em bactéria E. coli DE3 star pLys. Esta bactéria pareceu ser a melhor opção, já que é a mais utilizada para expressão de proteínas tóxicas. Diferentemente de outras linhagens, esta não apresenta escape (expressão basal, antes da indução com IPTG), pois possui o plasmídeo pLys, que confere resistência à cloranfenicol e codifica a lisozima T7, que reduz a expressão basal da T7 RNA polymerase e, portanto, só se observa a expressão da proteína após a indução com IPTG. Com esta cepa é possível que a cultura cresça até uma densidade significativa para expressão da proteína e, mesmo que as bactérias morram pela ação tóxica da proteína, uma quantidade considerável de proteína pode ser obtida.

\subsubsection{Candidato antigênico Atg1(Proteína V8)}

Uma alíquota de cada uma das lavagens do corpúsculo foi coletada e a amostra foi aplicada no gel.

A banda que representa o corpúsculo de inclusão é onde as proteínas estão aglomeradas. Dessa forma, o corpúsculo de inclusão foi purificado. As lavagens e as eluições (1M imidazol) estão representadas na Figura 30. 


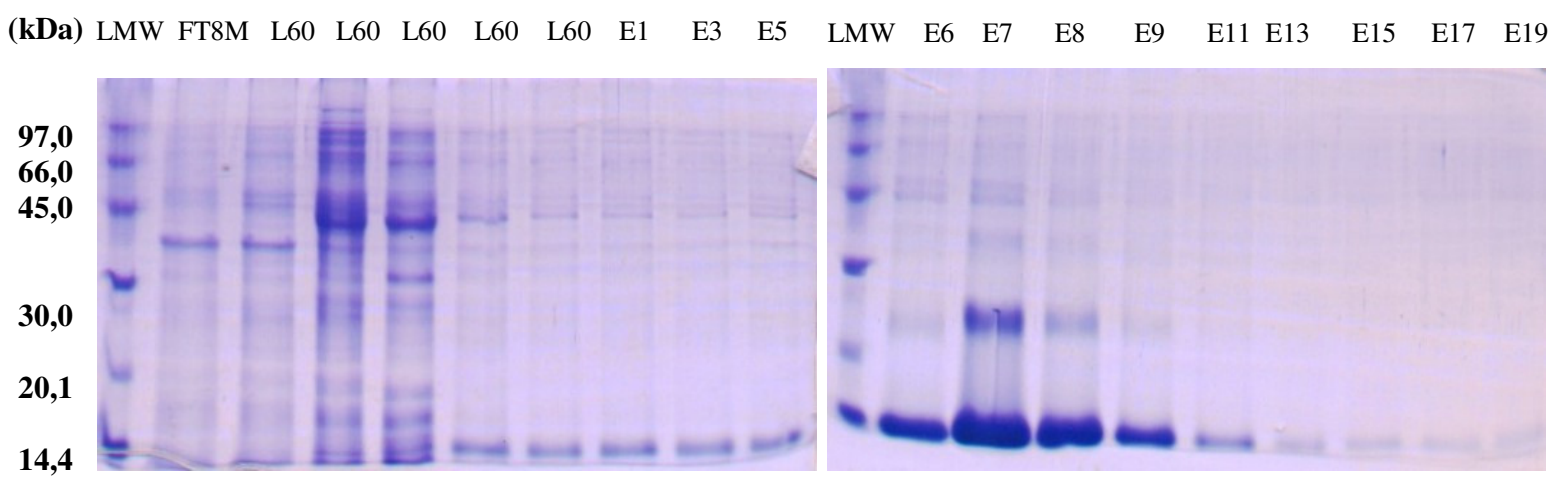

Figura 30: SDS-PAGE com amostras da expressão e purificação (corpúsculo de inclusão) da proteína Atg1 referente ao candidato antigênico Atg1. FT8M - flow thru 8M uréia, L60 lavagens do corpúsculo com 60mM imidazol (5 alíquotas), E1-E25 - eluições com 1M imidazol.

Na análise do gel de SDS-PAGE é possível notar uma purificação bem sucedida do corpúsculo, como pode ser observado da sexta eluição até a nona eluição.

\subsubsection{Candidato antigênico Atg2 (proteína V1)}

O corpúsculo de inclusão pôde ser observado na lavagem $8 \mathrm{M}$ uréia. Dessa forma, foi feita a purificação do corpúsculo sob as mesmas condições realizadas para a purificação da proteína Atg1. O resultado está apresentado abaixo (Figura 31).

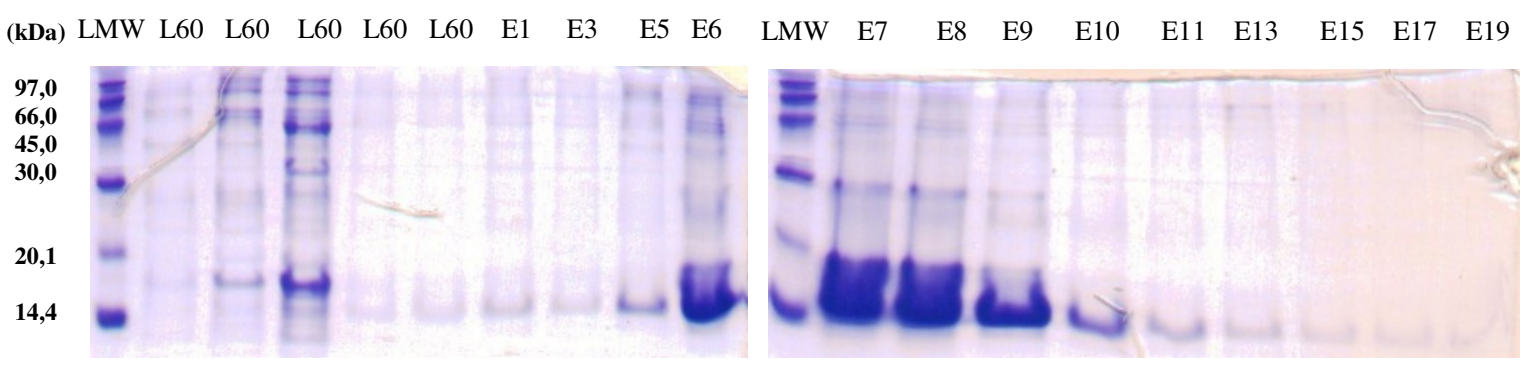

Figura 31: SDS-PAGE com amostras da expressão e purificação (corpúsculo de inclusão) da proteína Atg2 referente ao candidato antigênico Atg2. L60 - lavagens do corpúsculo com $60 \mathrm{mM}$ imidazol (5 alíquotas), E1-E25 - eluições com 1M imidazol.

Nota-se que a proteína começou a sair da coluna com mais intensidade a partir da sexta eluição e continuou até aproximadamente a décima eluição.

\subsubsection{Candidato antigênico Atg5 (Proteína V2)}

Da mesma forma que a expressão e purificação das proteínas Atg1 e Atg2, a purificação da proteína Atg5 também predominou no corpúsculo de inclusão, como já 
era esperado. O não-induzido e o induzido também não se apresentaram de forma evidente, porém sabe-se que houve indução pela análise das lavagens.

Da mesma forma, a proteína Atg5 teve o corpúsculo de inclusão purificado, como pode ser observado na Figura 32 seguinte.

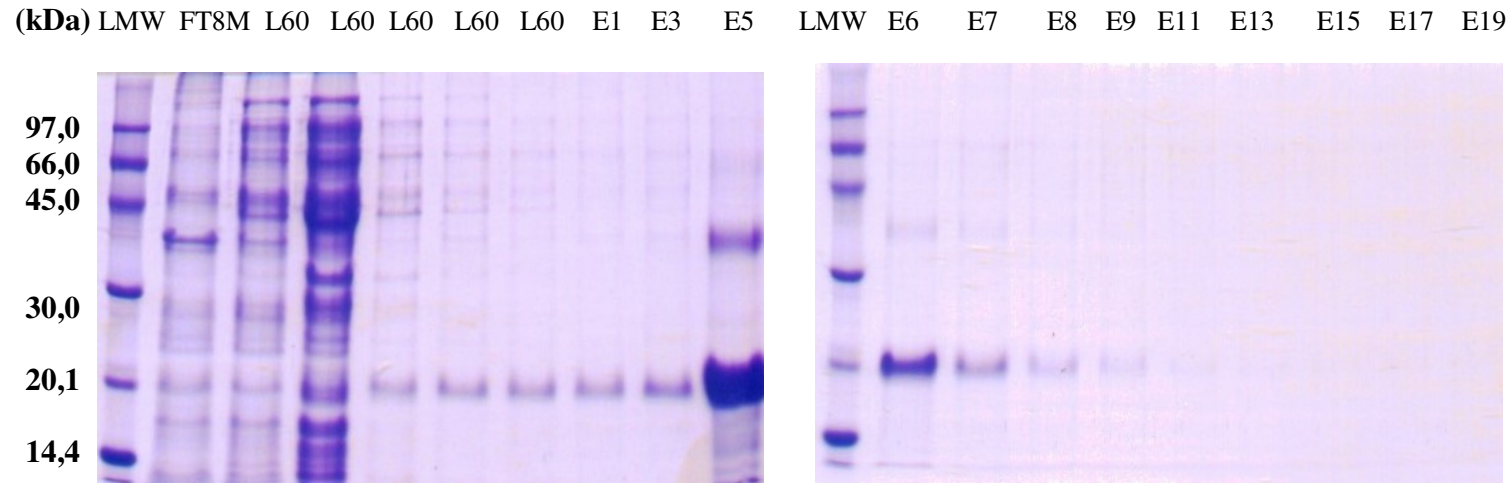

Figura 32: SDS-PAGE com amostras da expressão e purificação (corpúsculo de inclusão) da proteína Atg5 referente ao candidato antigênico Atg5. L60 - lavagens do corpúsculo com $60 \mathrm{mM}$ imidazol (5 alíquotas), E1-E25 - eluições com 1M imidazol.

Nota-se pelas eluições com 1M imidazol, que a purificação foi bem sucedida e a proteína passou a ser recuperada com mais intensidade a partir da quarta eluição (E4) e com maior intensidade na quinta eluição (E5).

Como foi comprovado, a maior parte das proteínas estava contida no corpúsculo de inclusão. Dessa forma, passamos a trabalhar apenas com as alíquotas da purificação do corpúsculo.

A diálise é necessária para se retirar o imidazol presente nas amostras coletadas durante a purificação, já que ele atrapalha o teste de ELISA. A uréia pode permanecer, por ser responsável pela estruturação da proteína e não influenciar o teste. Sem uréia, possivelmente a proteína precipitaria.

A diálise decorreu sem que a proteína precipitasse. A solução de $6 \mathrm{M}$ uréia foi diluída com a troca de solução, sem que isso prejudicasse o andamento da diálise.

Para a diálise, foram escolhidas amostras com a proteína mais intensa e mais evidente, a partir dos géis de SDS-PAGE mostrados anteriormente nas purificações do corpúsculo de inclusão.

As alíquotas de cada proteína foram colocadas em um mesmo tubo. Cada tubo foi dialisado individualmente, cada um em uma membrana de $3 \mathrm{kDa}$, colocado dentro de um béquer com $1 \mathrm{~L}$ de solução 6M uréia e tampão NaCl-Tris pH 6,8. 
As três proteínas foram colocadas no mesmo gel para facilitar o processo. Foi feita a curva de BSA e o resultado está apresentado na Figura 33 abaixo.

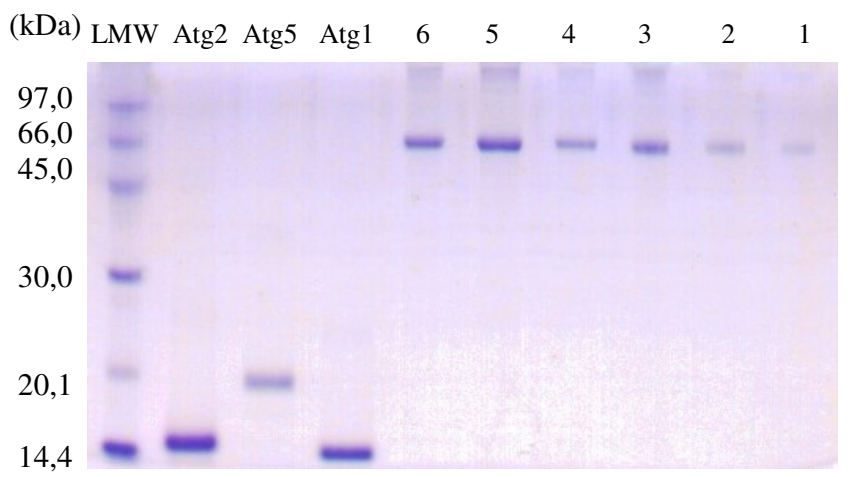

Figura 33: SDS-PAGE com amostras das proteínas purificadas e dialisadas juntamente com a curva de BSA. No gel, a curva de BSA tem início em $3 \mu \mathrm{g}-0,5 \mu \mathrm{g}$ de BSA, de 0,5 em 0,5.

Os valores numéricos da quantificação foram obtidos baseados na curva de BSA. Os valores numéricos para cada banda de proteína estão apresentados a seguir:

$\operatorname{Atg} 1-3,37 \mu \mathrm{g} / 10 \mu \mathrm{L}=337 \mathrm{ng} / \mu \mathrm{L}$

$\operatorname{Atg} 2-4,23 \mu \mathrm{g} / 10 \mu \mathrm{L}=423 \mathrm{ng} / \mu \mathrm{L}$

$\operatorname{Atg} 5-5,04 \mu \mathrm{g} / 10 \mu \mathrm{L}=504 \mathrm{ng} / \mu \mathrm{L}$

\subsubsection{A imunização genética (ou vacina de DNA) em camundongos}

As imunizações genéticas requerem uma quantidade considerável de DNA (candidato antigênico) para se injetar nos animais. Por essa razão, realizamos maxipreps para cada um dos candidatos antigênicos a fim de aumentar sua quantidade de DNA. Como há cinco animais em cada grupo, seriam necessários aproximadamente $1500 \mu \mathrm{g}$ de DNA por grupo $(100 \mu \mathrm{g} / \mathrm{animal}$ por dose).

Os animais foram anestesiados intraperitonialmente. Para alguns animais foram necessários mais do que $200 \mu \mathrm{L}$ de anestésico para o adormecimento total. Foi realizada então a injeção intramuscular dos DNAs antigênicos. O soro foi coletado e mantido no freezer a $-20^{\circ} \mathrm{C}$. A maior parte dos soros apresentou cor avermelhada forte, decorrente da hemólise de algumas hemáceas, especialmente no soro pré-imune. Não foi possível concluir a razão dessa hemólise. 


\subsubsection{Análise da resposta imune}

Dois testes ELISA diferentes foram preparados. No primeiro, usamos as proteínas recombinantes expressas e purificadas (Atg1, Atg2 e Atg5) a fim de preparar o coating do ELISA. Os soros primários foram obtidos dos camundongos imunizados com os respectivos DNAs (Atg1, Atg2 e Atg5).

O resultado está apresentado na Figura 34. Nela é possível notar o reconhecimento da proteína recombinante do coating com o anticorpo presente no soro dos camundongos. Títulos mais altos foram obtidos para Atg1 (1:5120) e Atg2 (1:10240). O terceiro candidato a antigênico testado (Atg5) não apresentou um alto título de anticorpos (1:160).

Este resultado pôde ser confirmado por observação no Western Blot realizado com as três proteínas recombinantes e os três soros obtidos das respectivas imunizações, como mostram aas Figuras 35 e 36. 

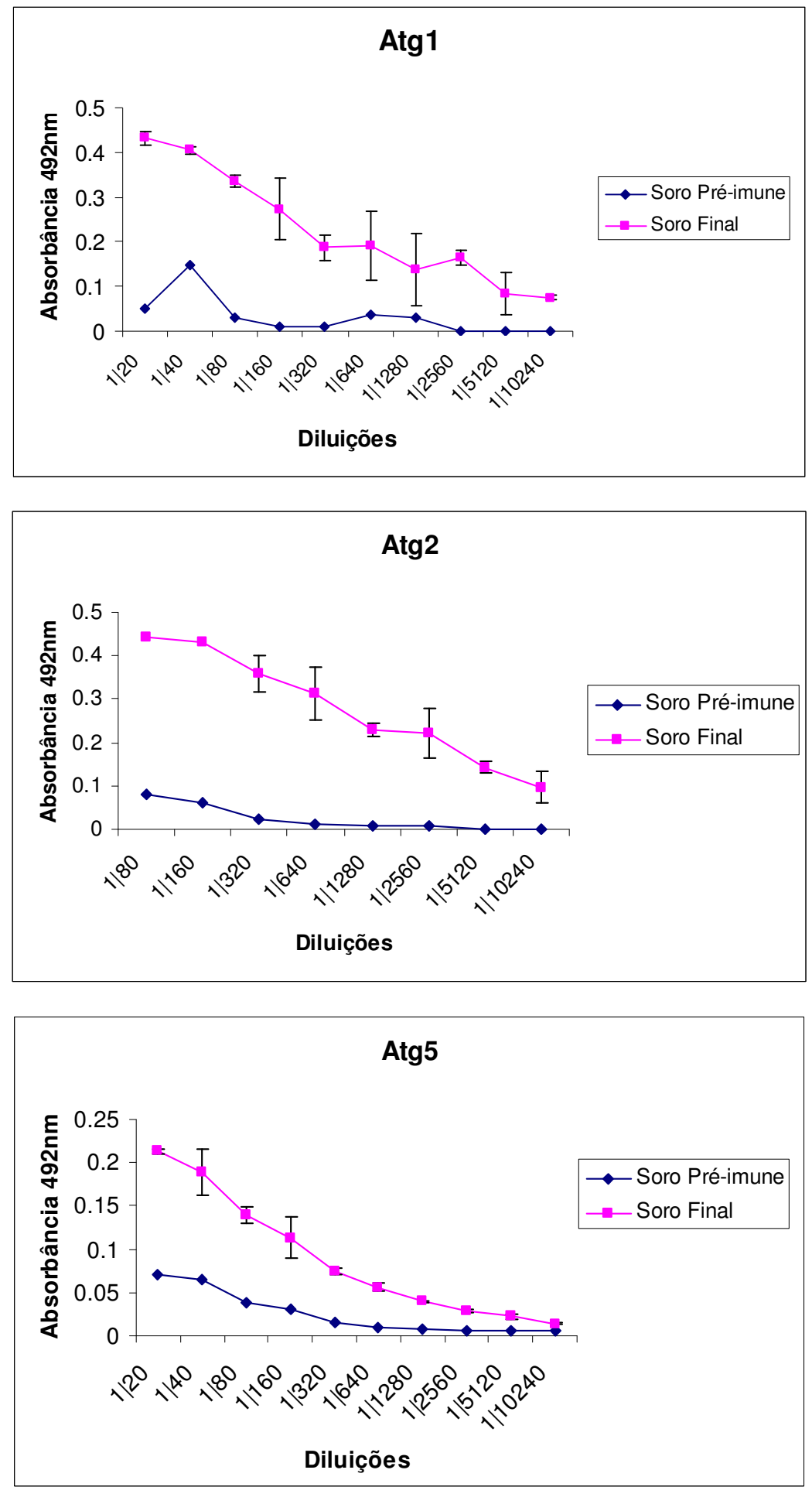

Figura 34: Gráfico de ELISA com as diferentes diluições e a absorbância detectada. Cada ponto no gráfico representa três titulações de uma mesma imunização (desvio padrão). 
LMW Atg2 Atg5 Atg1 Mcor Mfro Bjar CTX

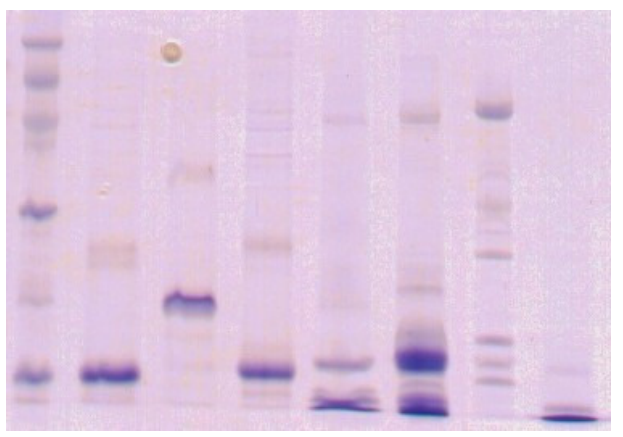

Figura 35: SDS-PAGE corado com Comassie Blue. Figura representa as três proteínas recombinantes obtidas (Atg1, Atg2 e Atg5) e venenos de algumas serpentes ( $M$. corallinus Mcor, M. frontalis - Mfro, B. jararaca - Bjar e Cardiotoxina - CTX).

LMW Atg2 Atg5 Atg1 Mcor Mfro Bjar CTX

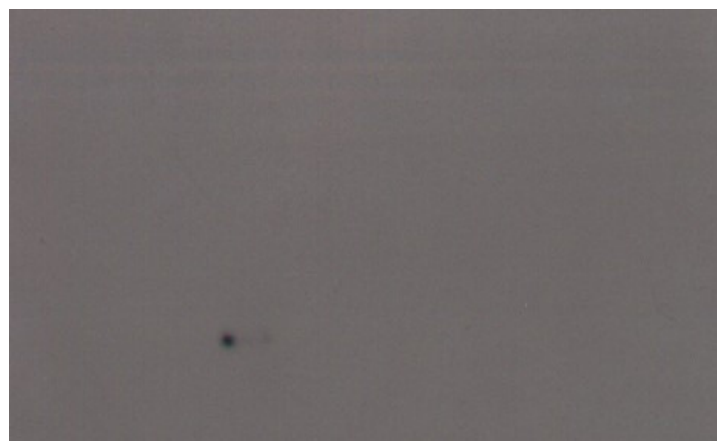

LMW Atg2 Atg5 Atg1 Mcor Mfro Bjar CTX

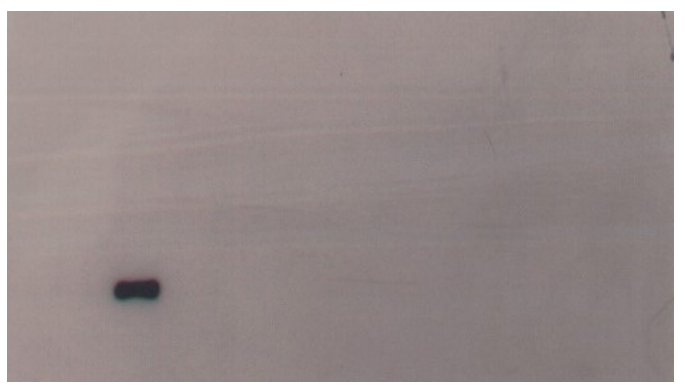

LMW Atg2 Atg5 Atg1 Mcor Mfro Bjar CTX

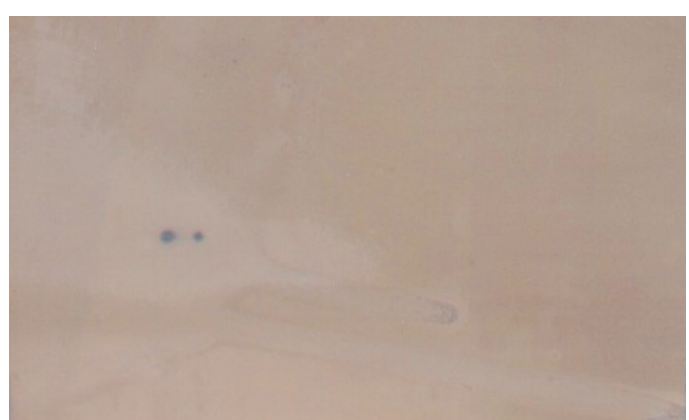

Figura 36: Resultado da revelação de Western Blot. Nota-se a detecção das proteínas recombinantes quando incubado com os soros provenientes da imunização genética em camundongos com os três candidatos respectivamente: Atg1, Atg2 e Atg5. 
Pela análise da figura, nota-se que houve reconhecimento de cada proteína recombinante quando em contato com o soro produzido nas imunizações. Cada soro reconheceu sua proteína específica, porém não houve reconhecimento dos venenos representados na figura (M. corallinus, $M$. frontalis, B. jararaca e Cardiotoxina).

No segundo teste ELISA, o coating foi preparado com as proteínas recombinantes Atg1 e Atg2, dessa vez contra os soros obtidos com a imunização em camundongos com os Atg3 e Atg4. Portanto, esta é uma análise cruzada para se descobrir se esses soros são semelhantes entre si ou se reagem com as proteínas recombinantes purificadas (Atg1 ou Atg2). Lembrando ainda que não dispúnhamos das formas recombinantes dos Atg3 e Atg4, produzidas em E. coli.

Neste teste foi possível perceber similaridade entre Atg2 e Atg3/4, mas não com Atg1 (Figura 37). Este resultado mostrou que estas seqüências sintetizaram proteínas similares; entretanto, Atg1 parece ter diferenças na estrutura ou na similaridade de epítopos (proteínas diferentes). 

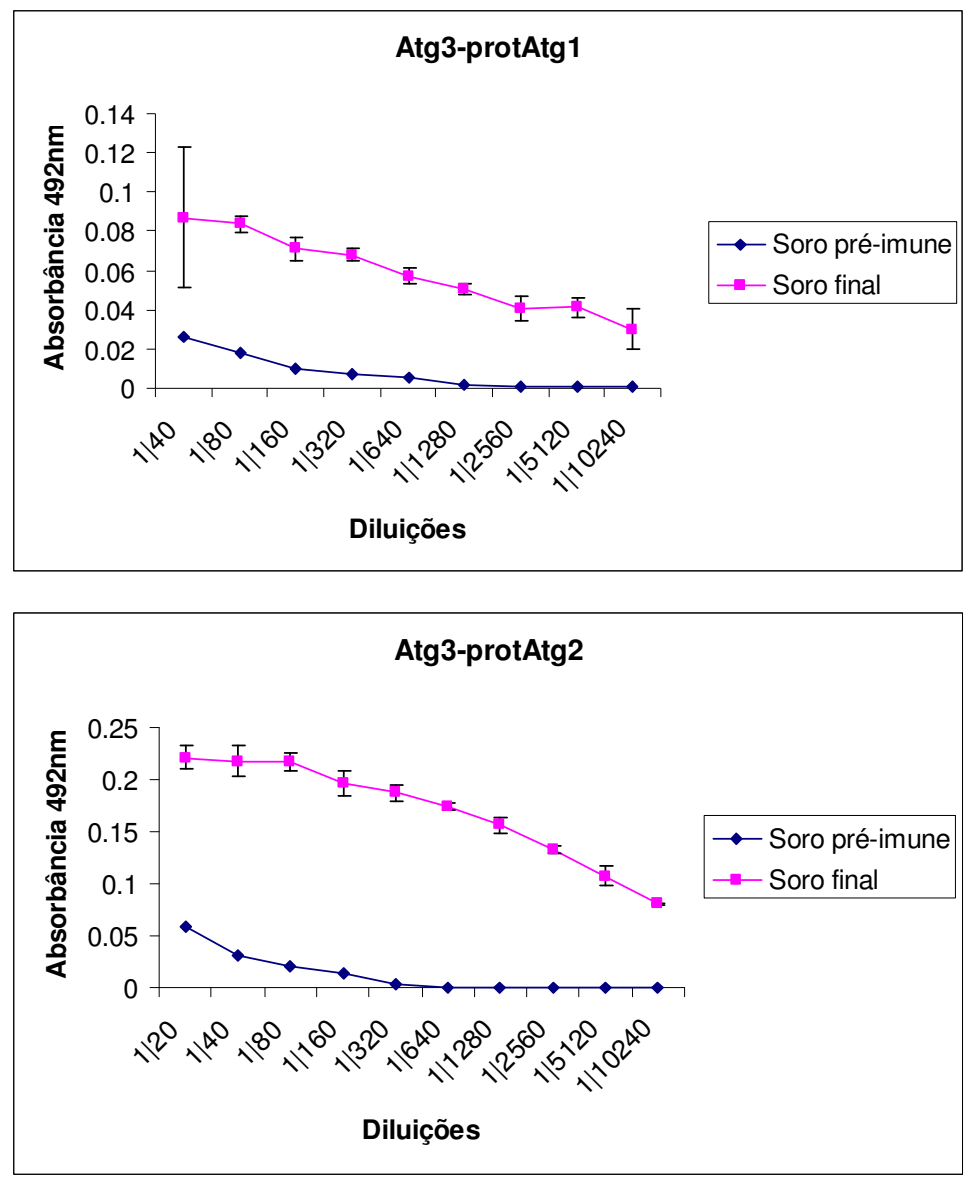

Figura 37: Gráficos de ELISA para a análise cruzada entre os soros contra Atg3 e

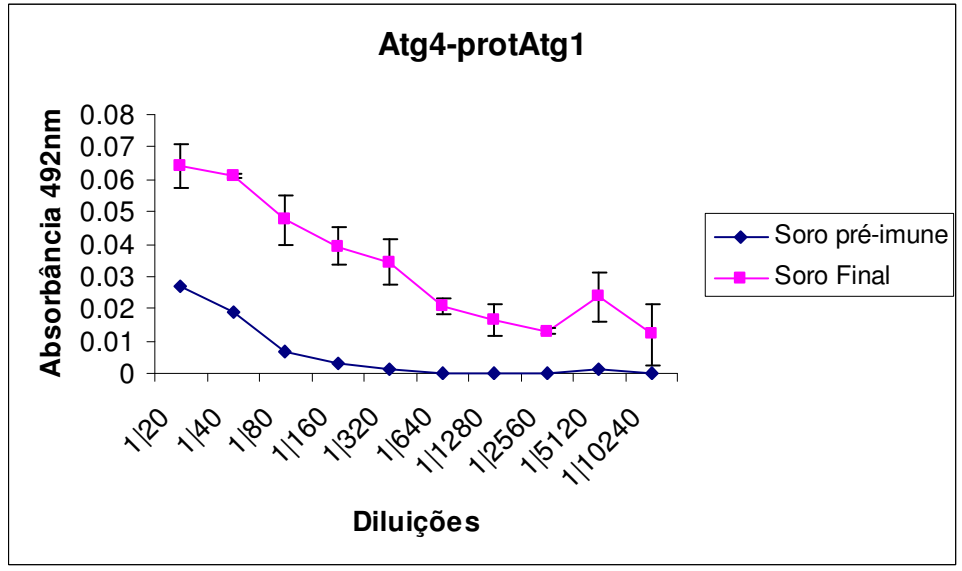
Atg4 com relação às proteínas recombinantes purificadas Atg1 e Atg2. Cada ponto no gráfico representa três titulações de uma mesma imunização (desvio padrão).

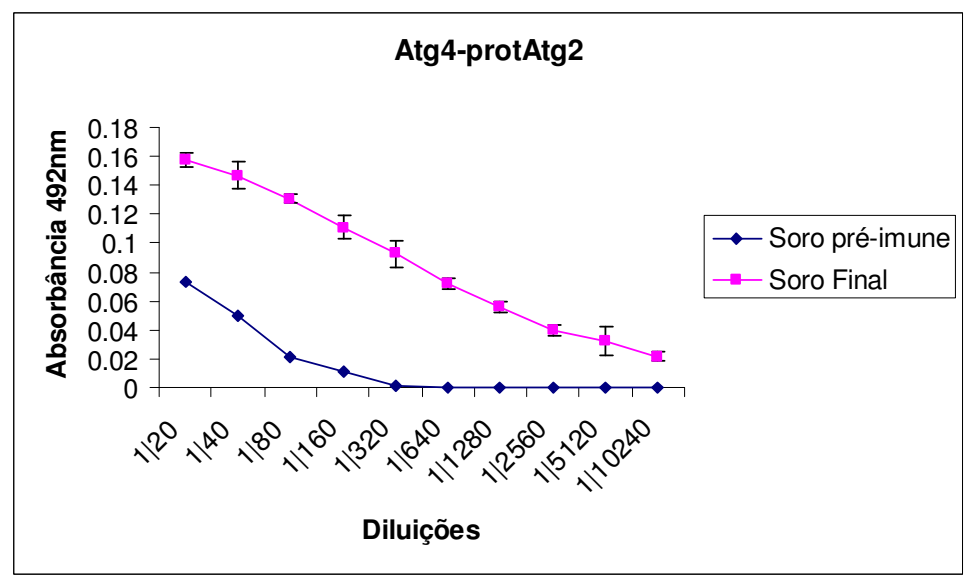




\subsubsection{Imunização tripla com três candidatos antigênicos}

A fim de testar a eficácia dos três candidatos antigênicos mais significativos contidos no veneno, inclusive em predominância, resolvemos imunizar camundongos com os três candidatos simultaneamente.

Pela análise dos gráficos de ELISA, é possível verificar o que aconteceu quando reagimos os três candidatos purificados (Atg1, Atg2 e Atg5) e o veneno puro de $M$. corallinus com o soro proveniente da imunização simultânea com DNA de três candidatos antigênicos (Figura 38).

Foi possível verificar um melhor reconhecimento pelo soro da imunização tripla para a proteína recombinante Atg2 purificada (1:5120), sendo que para as outras proteínas e o veneno puro os títulos obtidos foram mais baixos: Atg1 (1:320), Atg5 (1:120) e veneno puro de $M$. corallinus (1:120). A análise por Western Blot também foi realizada, porém não foram observadas bandas imunoreativas. Isso decorre, provavelmente, da maior sensibilidade do teste de ELISA em detectar anticorpos presentes do que o Western Blot, paralelamente aos baixos títulos apresentados para cada uma das proteínas e para o veneno puro. 

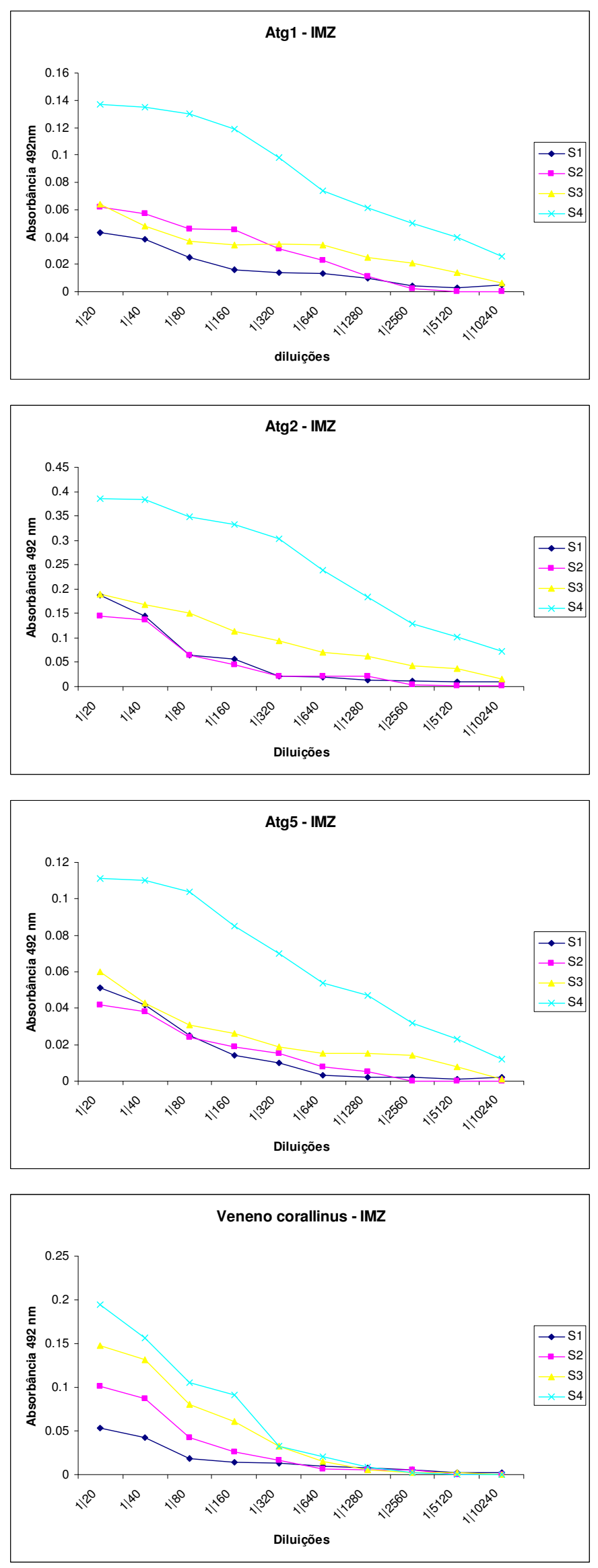

Figura 38: Gráficos de ELISA proveniente do resultado de imunização com três candidatos antigênicos (Atg1, Atg2 e Atg5). Os gráficos mostram a reação entre os coatings (V1, V8 e V2) com o soro proveniente da imunização com os três candidatos.

88 
Portanto, nossos resultados indicam que a imunização com DNA, via de regra, é capaz de gerar resposta imune contra as proteínas recombinantes. Entretanto, o veneno não foi reconhecido por estes soros. Isso indica que, possivelmente, haja algum problema na configuração estrutural das proteínas geradas nos camundongos como resultado da transfecção dos cDNAs. Talvez o dobramento incorreto leve à produção de anticorpos contra determinantes lineares, não capazes de reconhecer as proteínas nativas. Talvez os esquema de clonagem no vetor pSecTag2A, com vários "tags" para controle de expressão/purificação, tenha prejudicado o dobramento. Assim, novas construções e/ou diferentes vetores de expressão podem ajudar a melhorar a expressão desses antígenos. Diversos protocolos de imunização podem gerar resultados completamente distintos. Na injeção intramuscular, usada aqui, o DNA costuma ser injetado nos músculos tibial anterior ou quadríceps de camundongos. Normalmente, para este protocolo induz-se uma lesão no músculo com uma cardiotoxina antes da injeção do DNA para estimular o processo de reparo muscular (OLIVEIRA et al., 1999 e LAI \& BENNETT, 1998). Porém a CTX é um componente de venenos elapídicos (Naja $s p$.), justamente uma proteína da família das 3FTx e poderia assim induzir resposta imune correlata à do veneno. Outra forma usada em alguns casos é a injeção por meio de lipossomos que permitam que a dose tenha um efeito mais prolongado, uma vez que a liberação do DNA é paulatina. Um protocolo teoricamente mais promissor é o de biobalística. Nesse procedimento, cerca de 50 $\mathrm{g}$ de DNA são adsorvidos a microesferas de ouro $\left(0,2\right.$ a $4 \mathrm{~mm}$ de diâmetro) e injetados em alta velocidade $\left(1.500 \mathrm{~km} . \mathrm{h}^{-1}\right)$ na derme dos animais. O DNA é dissociado das micropartículas pela ação do líquido celular, ocorrendo ou não a integração do gene exógeno no genoma do organismo (OLIVEIRA et al., 1999). Esse procedimento já demonstrou em vários casos ser mais eficiente para indução de resposta imune do tipo Th2 (IL-4, IL-5, IL-10), ou seja, aquela que é mais indutora de anticorpos, o que é particularmente interessante para a geração de um soro hiperimune. O fator limitante desse procedimento é a disponibilidade do equipamento de disparo das biopartículas, tal como o Helius GeneGun (Bio-Rad) ou similar. Este tipo de protocolo é o que foi o utilizado por WAGSTAFF \& HARRISON, 2006, para a geração de um anti-soro contra toxinas do viperídeo E. oceollatus. Esses mesmos autores utilizaram o vetor pSecTagB por diferentes vias de imunização com antígenos de um nematóide, apresentando títulos muito maiores quando injetado por biobalística (Gene Gun) (HARRISON \& BIANCO, 2000). 
Outra questão importante a ser testada, é a contribuição de adjuvantes vacinais. Este campo é amplo e são utilizadas desde construções com plasmídeos codificando citocinas que aumentem a secreção de anticorpos, como o fator GM-CSF (granulocytemacrophage colony-stimulating factor), até adjuvantes mais comuns, como sais de alumínio, fosfato, monofosforil lipídio A, ou complexos com lipídios catiônicos (Ulmer et al., 1999 e FISCHER et al., 2003). Até mesmo o próprio DNA excedente usado na imunização tem caráter adjuvante, pois o padrão de metilação do DNA bacteriano é diferente do de mamífero, o que ativa o sistema imune inato (KLINMAN et al., 1997 e LIU et al., 2003).

Anos de estudo sobre vacinas de DNA mostraram que, diferentemente das vacinas inativadas ou de subunidade, as vacinas gênicas resultam em uma apresentação antigênica via moléculas de MHC de classe I e classe II, o que mimetiza o processo resultante de infecção natural ao ativar linfócitos $\mathrm{T}$ CD4+, CD8+ e a produção de anticorpos. Os diferentes tipos de resposta imune induzida pela administração de DNA justificam claramente sua aplicação nos campos das doenças infecciosas. (OLIVEIRA et al., 1999). A questão é saber derivar essa resposta para o objetivo de gerar soros hiperimunes e não apenas proteção. Algumas poucas tentativas de realizar esse objetivo são encontradas. Além daqueles trabalhos referentes à imunização com DNA de toxinas de serpentes, citados anteriormente, alguns outros esforços buscaram gerar hipersoros contra doenças bacterianas ou virais. FISCHER et al., 2003, por exemplo, usando uma composição lipídica catiônica junco com DNA, geraram títulos razoáveis de anticorpos contra o vírus da raiva em cavalos. Já HERRMANN et al., 2006, foram capazes de produzir em coelhos um antisoro contra o antrax capaz de neutralizar os efeitos deletérios da toxina de Bacillus anthracis.

Dessa forma, citando HARRISON \& BIANCO (2000), a aplicação das metodologias baseadas em DNA para o desenvolvimento de antivenenos terapêuticos representa a maior mudança conceitual na produção de antivenenos em um século e tem o potencial de promover uma terapia imunológica específica com melhor custo-benefício e menor periculosidade do que as atualmente usadas.

De qualquer forma, este nosso resultado, mesmo que ainda longe de uma aplicação terapêutica, são os primeiros passos para a utilização da imunização genética para fins de produção do soro anti-coralinus, o que nos encoraja a dar prosseguimento à pesquisa. 


\section{CONCLUSÃO}

1. O transcriptoma de Micrurus corallinus originou 1.438 ESTs que foram agrupadas em 611 clusters.

2. As proteínas com funções tóxicas representam $46 \%$ da expressão gênica das glândulas de veneno, sendo encontrados dez tipos de toxinas.

3. Proteínas de três dígitos (3FTx) e fosfolipases do tipo A2 (PLA2) são os cDNAs de toxinas mais representativos das glândulas de veneno.

4. As toxinas de três dígitos são extremamente diversificadas com varias isoformas de cDNAs de cada subtipo, prevalecendo as $\alpha$-neurotoxinas.

5. Algumas destas toxinas foram descritas pela primeira vez na Família Elapidae e outras foram descritas pela primeira vez no gênero Micrurus.

6. O grupo mais representativo de não toxinas são as proteínas com função celular relacionadas à transcrição e à tradução protéica.

7. A partir da análise do transcriptoma da glândula de veneno de Micrurus corallinus, cinco candidatos foram selecionados para uma imunização por DNA em camundongos

8. A análise da resposta imunológica indicou que a injeção com DNA dos candidatos antigênicos gerou anticorpos, pois houve o reconhecimento da proteína recombinante purificada pelo soro proveniente dos animais imunizados. 


\section{RESUMO}

A partir de uma biblioteca de cDNA de glândulas de veneno de Micrurus corallinus (cobra-coral), uma serpente da Família Elapidae bastante representada no Brasil e muito comum em áreas florestais tropicais, foram gerados 1.438 Expressed Sequences Tags (ESTs), agrupados em 611 clusters. O banco representa os genes mais expressos na glândula de veneno de $M$. corallinus. Os transcritos relacionados às toxinas apresentaram ao redor de $46 \%$ de representação nesse banco de seqüências. A composição geral das toxinas inclui: toxinas de três dígitos (3FTx) (24\%), fosfolipases A2 (PLA2) (16\%), lectinas do tipo C (5\%), entre outros. O banco permitiu não somente a identificação de possíveis toxinas, mas também de transcritos celulares, sendo a maioria envolvida nas funções fisiológicas de células da glândula de veneno. A maior parte dessas moléculas apresenta um envolvimento na expressão gênica e protéica, o que reflete uma alta especialização do tecido para a síntese de toxinas. A análise do transcriptoma de glândulas de veneno de $M$. corallinus possibilitou a identificação de alguns candidatos antigênicos para um anti-soro antielapídico alternativo. Cinco candidatos antigênicos foram selecionados por meio da análise do transcriptoma obtido: Atg1 (Grupo das neurotoxinas homolog 8), Atg2 (Grupo das neurotoxinas homolog 7/3/1), Atg3 (Outras neurotoxinas 1), Atg4 (Outras neurotoxinas 2) e Atg5 (fosfolipase do tipo A2). Avaliamos a viabilidade de imunização com o DNA desses candidatos. Para isso, os cinco grupos de antígenos foram clonados, primeiramente em pGEM-T e, posteriormente, em pSecTag2A, que é um vetor de expressão em células de mamíferos. As clonagens foram inicialmente testadas em células do tipo COS (transfecção transiente), entretanto não ficou clara a capacidade dessas células em expressar os antígenos. Para a análise da resposta imunológica da vacina de DNA, proteínas recombinantes produzidas em E. coli foram utilizadas para o coating de ELISA para detectar anticorpos presentes no soro primário proveniente da imunização com DNA. Os resultados mostraram que o soro dos animais imunizados foi capaz de reconhecer os antígenos recombinantes. Isso indica que a imunização por DNA em camundongos poderia ser uma boa alternativa em relação à imunização do veneno puro de serpente, que é custosa e muito depende da disponibilidade do veneno. Apesar da necessidade de testes complementares, esse é um resultado promissor, já que a produção de anticorpos pode ser alcançada por via de imunização intramuscular, mais prática para objetivos de produção. 


\section{ABSTRACT}

Micrurus corallinus (coral snake) is a tropical forest snake belonging to the Elapidae Family, and is very common in Brazil. From the cDNA library of its venom glands, 1.438 Expressed Sequences Tags (ESTs) were generated and grouped into 611 clusters. This database contains the most expressed genes in the M. corallinus venom glands. The transcripts related to toxins represent approximately $46 \%$ of the total genes in this database. The toxin compound consists of: three finger toxins (24\%), phospholipases A2 (PLA2s) (16\%), type-C lectins (5\%), among others. This database allowed not only the identification of possible toxins, but also the identification of cellular transcripts, most of which seems to be involved in physiological functions of venom gland cells. The majority of these molecules are involved in gene and protein expression, revealing the high level of specialization of the tissue for toxin synthesis. The analysis of the $M$. corallinus venom gland transcriptome allowed the identification of some antigenic candidates for an alternative antielapidic antiserum. Five antigenic candidates were selected after analysing the transcriptome: Atg1 (Homolog group 8), Atg2 (Homolog group 7/3/1), Atg3 (Other neurotoxins 1), Atg5 (A2-type phospholipase). These five antigenic groups were used for DNA immunization. Then they were first cloned in pGEM-T and, after, in pSecTag2A, which is an expression vector in mammal cells. The cloning was tested in COS-type cells (transient transfection), without signs of expression. To analyze the immunological response, recombinant proteins were produced in E. coli and used for ELISA coating to react with the primary serum deriving from the DNA immunization. The results showed that the serum from the immunized animals was able to recognize the recombinant antigens, indicating that the DNA immunization in mice could be a feasible alternative regarding the traditional immunization with crude snake venom, which is costly and heavily dependent on the availability of the venom. Regardless the need for additional tests, this is a promising result, because the antibody production can be achieved by intramuscular immunization, a more effective method when aiming for downstream production. 


\section{APÊNDICES}

\subsection{ABREVIATURAS}

3FTx - Proteínas com estrutura em três dígitos

ACh - Acetilcolina

ANP - Peptídeo Natriurético Atrial

Atg1 - Antígeno 1 - Neurotoxina homolog 8

Atg2 - Antígeno 2 - Neurotoxina homolog 7/3/1

Atg3 - Antígeno 3 - Outras neurotoxinas 1

Atg 4 - Antígeno 4 - Outras neurotoxinas 2

Atg5 - Antígeno 5 - PLA2

BNP - Peptídeo Natriurético Cerebral

BPP - Peptídeo Potenciador de Bradicinina

BSA - Albumina Sérica Bovina

CMV - Citomegalovírus (Promotor de vetor de expressão de células eucariontes)

CNCZAP - Coordenação Nacional de Controle de Zoonoses e Animais Peçonhentos

CNP - Peptídeo natriurético tipo C

CTX - Cardiotoxinas

DEMEN - Meio Dulbecco High Glucose

DNP - Peptídeo Natriurético da serpente do gênero Dendroaspis

DO - Densidade Óptica

ELISA - Enzyme-linked Immunosorbent Assay

EST - Expressed Sequence Tag (Etiquetas de Sequências Expressas)

ExoI - Exonuclease I

GFP - Green Fluorescent Protein

GPI - Glicofosfatidilinositol

IM - intramuscular

IPTG - indução da expressão do promotor lac e seus derivados - isopropil $\beta$ -

thiogalactoside

LMW - padrão de peso molecular (Low Molecular Weight)

$\mathrm{nAChR}$ - receptor nicotínico de acetilcolina

NGF- Nerve Growth Factor (neurotrofinas) 
nxh1 - neurotoxina homolog 1

nxh3 - neurotoxina homolog 3

nxh7 - neurotoxina homolog 7

nxh8 - neurotoxina homolog 8

OPD - o-dihidrocloreto de fenilenodiamina

ORF - Open Reading Frame

PBS - Phosphate Buffered Saline

PBS-T - Phosphate Buffered Saline + Tween

PCR - Polymerase Chain Reaction (Reação em cadeia da polimerase)

pI - Ponto Isoelétrico

PLA2 - Fosfolipase do tipo A2

SAP - Shrimp Alcaline Phosphatase

SDS-PAGE - eletroforese em gel de poliacrilamida + sulfato dodecil de sódio

SV40 - Promotor de vetor de expressão de células eucariontes

SVMP - Metaloproteinase de veneno de serpentes

WAP - Whey Acidic Proteins 


\section{2 ÍNDICE DE FIGURAS}

Figura 1: A) Quatro principais tipos de dentições encontradas entre as Famílias de Serpentes Atractaspididae, Viperidae, Colubridae e Elapidae. B) Ausência da fosseta loreal nos elapídeos e comparação com os viperídeos.

Figura 2: Três gêneros principais encontrados entre as cobras-corais: Micrurus, Leptomicrurus e Micruroides.. . .14

Figura 3: Filogenia de cobras-corais de Roze (1987). S.A. = América do Sul...........................15

Figura 4: Esquema da estratégia utilizada para clonagem dos candidatos...............................35

Figura 5: Esquema do desenho de primers específicos para clonagem dos candidatos antigênicos. .35

Figura 6: Mapa do vetor pSecTag2A utilizado na clonagem final realizada com os candidatos antigênicos. 37

Figura 7: Esquema das dosagens aplicadas nos camundongos durante processo de imunização com os candidatos antigênicos selecionados.

Figura 8: Representação gráfica da proporção dos tipos de toxinas encontradas em glândulas de veneno de Micrurus corallinus)

Figura 9: Representação gráfica da proporção dos tipos de proteínas celulares encontradas em glândulas de veneno de Micrurus corallinus.

Figura 10: Proteínas de três dígitos encontradas na glândula de veneno de $M$. corallinus ( $\mathrm{n}^{\circ}$ de clones/grupo - gráfico maior e $\mathrm{n}^{\circ}$ de clones/cluster - gráfico menor). .52

Figura 11: Alinhamento dos clusters de fosfolipase do tipo A2 obtidos por análise do transcriptoma da glândula de veneno de $M$. corallinus.

Figura 12: A) Alinhamento das lectinas do tipo $C$ e seus homólogos estruturais juntamente com as lectinas fisiológicas animais. B) Análise filogenética Baesiana dessas lectinas tipo C. $.57 / 58$

Figura 13: Alinhamento entre as seqüências de peptídeo natriurético encontrado em análise do banco de dados

Figura 14: Dois clones encontrados no banco de dados de $M$. corallinus representando duas regiões fracamente contíguas da L-aminoácido oxidase.

Figura 15: Alinhamento dos clusters que representam o grupo homolog 8 (nxh8).

Figura 16: Alinhamento dos clusters que representam o grupo nos quais incluem nxh1, nxh3 e nxh7...

Figura 17: Alinhamentos dos clusters representantes do grupo "outras neurotoxinas" .68

Figura 18: Alinhamento dos principais candidatos de proteínas de três dígitos escolhidos a partir do transcriptoma de M. corallinus.

Figura 19: Candidato selecionado para representar as fosfolipases do tipo A2 - PLA2 (BINS0036C - 196 clones). 
Figura 20: A) PCRs dos clones MCAL01H08 e MCAL09C06, os dois clones representantes do grupo Atg1. B) Digestão do clone MCAL01H08.5 escolhido para representar o Atg1 ................70

Figura 21: Screening por PCR (pSecTagA2 + fragmento/clone 1.5) .....................................71

Figura 22: A) PCRs dos clones MCAL07D03 (1) e MCAL07H04, (2) os dois clones representantes do Atg2. B) Digestão do clone MCAL07D03.2 escolhido para representar o Atg2

Figura 23: Screening por PCR (pSecTagA2 + fragmento/clone MCAL07D03.2).......................72

Figura 24: A) Amplificação bem sucedida do clone MCAH05B08 (Atg3). B) Digestão do clone MCAH05B08.1 escolhido para representar o grupo Atg3.....................................................

Figura 25: A) PCRs dos clones MCAL07E03 (1) e MCAL09G04 (2), os dois clones representantes do Atg4. B) Digestão do clone MCAL07E03.5. .73

Figura 26: A) PCRs dos clones MCAL09A06 (1) e MCAL06A06 (2), os dois clones representantes do Atg5. B) Digestão do clone MCAL09A06.1 escolhido para representar o

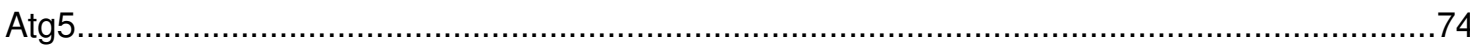

Figura 27: Screening por PCR (pSecTagA2 + fragmento/clone MCAL09A06.1)........................75

Figura 28: SDS-PAGE contendo amostras de sobrenadante e do extrato de células................76

Figura 29: SDS-PAGE contendo amostras de sobrenadante e do extrato de células................77

Figura 30: SDS-PAGE com amostras da expressão e purificação (corpúsculo de inclusão) da proteína Atg1 referente ao candidato antigênico Atg1. 79

Figura 31: SDS-PAGE com amostras da expressão e purificação (corpúsculo de inclusão) da proteína Atg2 referente ao candidato antigênico Atg2. .79

Figura 32: SDS-PAGE com amostras da expressão e purificação (corpúsculo de inclusão) da proteína Atg5 referente ao candidato antigênico Atg5. 80

Figura 33: SDS-PAGE com amostras das proteínas purificadas e dialisadas juntamente com a

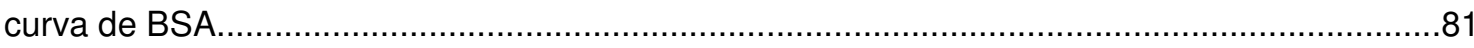

Figura 34: Gráfico de ELISA com os diferentes títulos e a absorbância detectada. .83

Figura 35: Figura representa as três proteínas recombinantes obtidas (Atg1, Atg2 e Atg5) e venenos de algumas serpentes.

Figura 36: Resultado da revelação de Western Blot. .84

Figura 37: Gráficos de ELISA para a análise cruzada entre Atg3 e Atg4 com relação às proteínas recombinantes purificadas Atg1 e Atg2. .86

Figura 38: Gráficos de ELISA proveniente do resultado de imunização com três candidatos antigênicos (Atg1, Atg2 e Atg5). .88 


\section{3 ÍNDICE DE TABELAS}

Tabela 1: Coeficientes de incidência anual (por 100 mil habitantes) dos acidentes ofídicos por região fisiográfica. Brasil, 1990 a 1993.

Tabela 2: Diagnóstico dos acidentes ofídicos segundo gênero no Brasil....... .22

Tabela 3: Comparação entre o número de acidentes elapídicos e o número de acidentes ofídicos ocorridos entre 2001 e 2005 .22

Tabela 4: Quadro geral da situação dos animais entregues ao Instituto Butantan para cada gênero de serpentes, a quantidade de veneno e a longevidade em cativeiro)...... .25

Tabela 5: Apresentação dos diferentes candidatos, clusters, clones e tamanhos (pb) respectivos.

Tabela 6: As proteínas Atg1, Atg2 e Atg5 com seus respectivos pontos isoelétricos ( $\mathrm{pl}$ ) e o nome da proteína de acordo com a similaridade com o banco de dados

Tabela 7: Três valores diferentes de identidade testados como parâmetro de estringência no CAP3 e os resultados obtidos.

Tabela 8: Representação dos clusters obtidos a partir das ESTs da glândula de veneno de $M$. corallinus.

Tabela 9: Representação dos tipos de toxinas encontradas na glândula de veneno de Micrurus corallinus, com o respectivo número de clusters e clones. 


\section{BIBLIOGRAFIA}

ADAMS, M. D.; KELLEY, J. M.; GOCAYNE, J. D.; DUBNICK, M.; POLYMEROPOULOS, M. H.; XIAO, H.; MERRIL, C. R.; WU, A.; OLDE, B.; MORENO, R. F.; KERLAVAGE, A. R.; MCCOMBIE, W. R.; VENTER, J. C. Complementary DNA sequencing: Expressed Sequence Tags and Human Genome Project. Science, 252. 1991. Pp. 1651-1656.

AIRD, S. D.; JORGE DA SILVA, N. Jr. Comparative enzymatic composition of Brazilian coral snake (Micrurus) venom. Comp. Biochem. Physiol. 1991. 99B: 287-294.

ARNI, R. K.; WARD, R. J. Phospholipase A2: A structural review. Toxicon. 1996. 34:327-841.

BARROS, A. C.; FERNANDES, D. P.; FERREIRA, L. C.; DOS SANTOS, M. C. Local effects induced by venoms from five species of genus Micrurus sp. (coral snakes). Toxicon. 1994. 32(4):445-52.

BATISTA, I. F.; CHUDZINSKI-TAVASSI, A. M.; FARIA F.; SIMONS, S. M.; BARROSBATESTTI, D. M.; LABRUNA, M. B.; LEÃO, L. I.; HO, P. L.; JUNQUEIRA DE AZEVEDO, I. L. M. Expressed sequence tags (ESTs) from the salivary glands of the tick Amblyomma cajennense (Acari: Ixodidae). Toxicon. 2008. 51(5):823-34.

BRAZIL, V.; BRAZIL FILHO, V. Do envenenamento elapídico em confronto com o choque anafilático. Bol. Inst. Vital Brazil. 1933. 15:43-49.

CALVETE, J. J.; JUÁREZ, P.; SANZ, L. Snake venomics: Strategy and applications. J. Mass. Spectrom. 2007. 42(11):1405-14.

CAMPBELL, J. A.; LAMAR, W. W. The Venomous Reptiles of Western Hemisphere: Coral snakes and sea snakes, Elapidae Family. Nova York: Cornell University Press, 2004. Vol. I

CARDOSO, D. F.; LAFAYE P.; NATO, F. et al. Neutralizing human anti-crotoxin scFv isolated from a non-imunized phage library. In: $12^{\mathrm{TH}}$ WORLD CONGRESS INTERNATIONAL SOCIETY TOXINOLOGY. Isla Margarita, 1997.

CARDOSO, J. L. C.; FRANÇA, F. O. S.; WEN, F. H.; MÁLAQUE, C. M. S.; HADDAD Jr., V. Animais peçonhentos no Brasil: Biologia, clínica e terapêutica dos acidentes. São Paulo: Sarvier, Fapesp. 2003. 468 p. 
CHEN, S.; GUO, J. H.; SAIYIN, H.; CHEN, L.; ZHOU, G. J.; HUANG, C. Q.; YU, L. Cloning and characterization of human CAGLP gene encoding a novel EF-hand protein. DNA Seq. 2004. 15(5-6):365-8.

CHING, A. T.; ROCHA, M. M.; PAES LEME, A. F.; PIMENTA, D. C.; DE FÁTIMA, D.; FURTADO, M.; SERRANO, S. M.; HO, P. L.; JUNQUEIRA DE AZEVEDO, I. L. M. Some aspects of the venom proteome of the Colubridae snake Philodryas olfersii revealed from a Duvernoy's (venom) gland transcriptome. FEBS Lett. 2006. 580(18):4417-22.

DE OLIVEIRA, U. C.; ASSUI, A.; DA SILVA, A. R., DE OLIVEIRA, J. S.; HO, P. L. Cloning and characterization of a basic phospholipase A2 homologue from Micrurus corallinus (coral snake) venom gland. Toxicon. 2003. 42(3):249-55.

DOWLING, H. G.; DUELLMAN, W. E. Systematic Herpetology: A synopsis of families and higher categories. Nova York: Hiss Publications, 1978.

DU, X. Y.; ClEMETSON, J. M.; NAVDAEV, A.; MAGNENAT, E. M.; WELlS, T. N.; CLEMETSON, K. J., Ophioluxin, a convulxinlike C-type lectin from Ophiophagus hannah (King cobra) is a powerful platelet activator via glycoprotein VI. J. Biol. Chem. 2002. 277: 35124-35132.

DUFTON, M. J.; HIDER, R. C. Classification of phospholipases A2 according to sequence. Evolutionary and pharmacological implications. Eur. J. Biochem. 1983. 137:545-551.

ENDO, T.; TAMIYA, N. "Structure-functions relationships of postsynaptic neurotoxins from snake venoms." In: HARVEY, A. L. Snake Toxins, International Encyclopedia Of Pharmacology And Therapeutics. Nova York: Pergamon Press, 1991.

FARIA, F.; JUNQUEIRA DE AZEVEDO, I. L. M.; HO, P. L.; SAMPAIO, M. U.; CHUDZINSKI-TAVASSI, A. M. Gene expression in the salivary complexes from Haementeria depressa leech through the generation of expressed sequence tags. Gene. 2005. 349:173-85.

FERNANDES-PEDROSA, M. F.; JUNQUEIRA DE AZEVEDO, I. L. M.; GONCALVES-DEANDRADE, R. M.; VAN DEN BERG, C. W.; RAMOS, C. R.; HO, P. L.; TAMBOURGI, D. V. Molecular cloning and expression of a functional dermonecrotic and haemolytic factor from Loxosceles laeta venom. Biochem. Biophys. Res. Commun.. 2002. 298(5): 638-645. 
FISCHER, L.; MINKE, J.; DUFAY, N.; BAUDU, P.; AUDONNET, J. C. Rabies DNA vaccine in the horse: strategies to improve serological responses. Vaccine. 2003. 21(31):45934596.

FOHLMAN, J.; LIND, P.; EAKER, D. Taipoxin, an extremely potent presynaptic snake venom neurotoxin: Elucidation of the primary structure of the acidic carbohydratecontaining taipoxin-subunit, a prophospholipase homolog. FEBS Lett. 1977. 84:367-371.

FRANCIS, B. R.; WILLIAMS, E. S.; SEEBART, C.; KAISER, I. I. Proteins isolated from the venom of the common tiger snake (Notechis scutatus scutatus) promote hypotension and hemorrhage. Toxicon. 1993. 31(4):447-58.

FRANCIS, B. R.; COFFIELD, J. A.; SIMPSON, L. L., KAISER, I. I. Amino acid sequence of a new type of toxic phospholipase A2 from the venom of the Australian tiger snake (Notechis scutatus scutatus). Arch. Biochem. Biophys. 1995. 318:481-488.

FRANCIS, B. R.; DA SILVA JR., N. J.; SEEBART, C.; CASAIS E SILVA, L. L.; SCHMIDT, J. J.; KAISER, I. I. Toxins isolated from the venom of the Brazilian coral snake (Micrurus frontalis frontalis) include hemorrhagic type phospholipases $\mathrm{A} 2$ and postsynaptic neurotoxins. Toxicon. 1997. 35:193-203.

FRANCISCHETTI, I. M.; MY-PHAM, V.; HARRISON, J.; GARFIELD, M. K., RIBEIRO, J. M. Bitis gabonica (Gaboon viper) snake venom gland: Toward a catalog for the full-length transcripts (cDNA) and proteins. Gene. 2004. 337:55-69.

FRY, B. G.; VIDAL, N.; NORMAN, J. A.; VONK, F. J.; SCHEIB, H.; RAMJAN, S. F.; KURUPPU, S.; FUNG, K.; HEDGES, S. B.; RICHARDSON, M. K.; HODGSON, W. C.; IGNJATOVIC, V.; SUMMERHAYES, R.; KOCHVA, E. Early evolution of the venom system in lizards and snakes. Nature. 2006. 439:584-588.

FUJIMI, T. J.; KARIYA, Y.; TSUCHIYA, T., TAMIYA, T. Nucleotide sequence of phospholipase $A(2)$ gene expressed in snake pancreas reveals the molecular evolution of toxic phospholipase A(2) genes. Gene. 2002. 292(1-2):225-31.

GRAHAM, R. L.; GRAHAM, C.; MCCLEAN, S.; CHEN, T.; O'ROURKE, M.; HIRST, D.; THEAKSTON, D.; SHAW, C. Identification and functional analysis of a novel bradykinin inhibitory peptide in the venoms of New World Crotalinae pit vipers. Biochem. Biophys. Res. Commun. 2005. 338(3):1587-92. 
GUTIÉRREZ, J. M.; ROJAS, G.; DA SILVA JR., N. J.; NÚÑEZ, J. Experimental myonecrosis induced by the venoms of South American Micrurus (coral snakes). Toxicon. 1992. 30(10):1299-1302.

HARRIS, J. B. Phospholipases in snake venoms and their effects on nerve and muscle. In: Snake Toxins, International Encyclopedia of Pharmacology and Therapeutics. HARVEY, A. L. Nova York: Pergamon Press, 1991. Pp. 91-129.

HARRISON, R. A.; BIANCO, A. E. DNA immunisation with Onchocerca volvulus genes, Ovtmy-1 and OvB20: serological and parasitologicaloutcomes following intramuscular or GeneGun delivery in a mousemodel of Onchocerciasis. Parasite Immunol. 2000. 22(5):249-57.

HARRISON, R. A.; MOURA-DA-SILVA, A. M.; LAING, G. D.; WU, Y.; RICHARDS, A.; BROADHEAD, A. Antibody from mice immunized with DNA encoding the carboxyldisitegrin and cysteine-rich domain (JD9) of the haemorrhagic metalloprotease, Jararhagin, inhibits the main lethal component of viper venom. Clin. Exp. Immunol. 2000. 121:358-363.

HARRISON, R. A. Development of venom toxin-specific antibodies by DNA immunization: Rationale and strategies to improve therapy of viper envenoming. Vaccine. 2004. 2:16481655.

HASSETT, D. E.; WHITTON, J. L. DNA immunization. Trends in Microbiology. 1996. 4(8): 307-312.

HERRMANN, J. E.; WANG, S.; ZHANG, C.; PANCHAL, R. G.; BAVARI, S.; LYONS, C. R.; LOVCHIK, J. A.; GOLDING, B.; SHILOACH, J.; LU, S. Passive immunotherapy of Bacillus anthracis pulmonary infection in mice with antisera produced by DNA immunization. 2006.

HIGASHI, H. G.; GUIDOLIN, R.; NISHIKAWA, A. K. et al. Produção em cavalos de anticorpos antiveneno total de Crotalus durissus terrificus em cavalos por fosfolipase A2. Mem. Inst. Butantan. 1989. 51:91-100.

HIGASHI, H. G.; GUIDOLIN, R.; CARICATTI, C. P.; FERNANDES, I.; MARCELINO, J. R.; MORASS, J. F.; YAMAGUCHI, I.; STEPHAN, M. A.; DIAS DA SILVA, W.; TAKEHARA, H. A. Antigenic cross-reactivity among components of Brazilian Elapidae snake venoms. J. Med. Biol. Res. 1995. 28:767-771. 
HO, P. L.; SOARES, M. B.; YAMANE, T.; RAW, I. Reverse Biology applied to Micrurus corallinus, a South American Coral Snake. Toxicol. Toxin Reviews. 1995. 14(3), 327337.

HO, P. L.; SOARES, M. B.; MAACK, T.; GIMENEZ, I.; PUORTO, G.; FURTADO, M. F. D.; RAW, I. Cloning of an unusual natriuretic peptide from the South American coral snake Micrurus corallinus. Eur. J. Biochem. 1997. 250:144-149.

HUANG, M. Z.; GOPALAKRISHNAKONE, P.; CHUNG, M. C. M.; KINI, R. M. Arch. Biochem. Biophys. 1996. 332:150-156.

HUANG, X.; MADAN, A. CAP3: A DNA sequence assembly program. Genome Res. 1999. 9(9):868-77.

HUNG, C. C.; CHIOU, S. H. Fibrinogenolytic proteases isolated from the snake venom of Taiwan habu: serine proteases with kallikrein-like and angiotensin-degrading activities. Biochem. Biophys. Res. Commun. 2001. 281:1012-1018.

JORGE DA SILVA JR., N.; GRIFFIN, P. R.; AIRD, S. D. Comparative chromatography of Brazilian coral snake (Micrurus) venoms. Comp. Biochem. Physiol. 1991; 100B:117-26.

JORGE DA SILVA JR., N.; BUCARETCHI, F. "Mecanismos de ação do veneno elapídico e aspectos clinicos dos acidentes.” In: Animais peçonhentos no Brasil: Biologia, clínica e terapêutica dos acidentes. São Paulo: Sarvier, FAPESP, 2003. Pp. 99-107.

JUNQUEIRA DE AZEVEDO, I. L. M.; FARSY, S. H. P.; OLIVEIRA, M. L. S.; HO, P. L. Molecular Cloning and Expression of a Functional Snake Venom Vascular Endothelium Growth Factor (VEGF) frrom Bothrops insularis Pit Viper. A new membeer of the VEGF Family of Proteins. Journal of Biological Chemistry. 2001. 276(43): 339836-39842.

JUNQUEIRA DE AZEVEDO, I. L. M.; HO, P. L. A survey of gene expression and diversity in the venom glands of the pitviper snake Bothrops insularis through the generation of expressed sequence tags (ESTs). Gene. 2002. 299: 279-291.

JUNQUEIRA DE AZEVEDO, I. L. M. Análise da diversidade do transcriptoma da glândula de veneno da serpente Bothrops insularis: identificação e caracterização de novas proteínas através da geração de Expressed Sequences Tags (ESTs). 2003a. Tese de doutorado. Instituto de Biociências. São Paulo. 
JUNQUEIRA DE AZEVEDO, I. L. M.; PERTINHEZ, T.; SPISNI, A.; CARREÑO, F. R.; FARAH, C. S.; HO, P. L. Cloning and expression of calglandulin: a new EF-hand protein from the venom glands of Bothrops insularis snake. Biochim. et Biophys. Acta. 2003b. 1648(1-2):90-98.

JUNQUEIRA DE AZEVEDO, I. L. M.; CHING, A. T.; CARVALHO, E.; FARIA, F.; NISHIYAMA JR, M. Y.; HO, P. L.; DINIZ, M. R. Lachesis muta (Viperidae) cDNAs reveal diverging pit viper molecules and scaffolds typical of cobra (Elapidae) venoms: implications for snake toxin repertoire evolution. Genetics. 2006. 173(2):877-89.

KASHIMA, S.; SOARES, A. M.; ROBERTO, P. G.; PEREIRA, J. O.; ASTOLFI-FILHO, S.; CINTRA, A. O.; FONTES, M. R. M.; GIGLIO, J. R.; FRANÇA, S. C. cDNA sequence and molecular modeling of a nerve growth factor from Bothrops jararacussu venomous gland. Biochimie. 2002. 84:675-680.

KASHIMA, S.; ROBERTO, P. G.; SOARES, A. M.; ASTOLFI-FILHO, S.; PEREIRA, J. O.; GIULIATI, S.; FARIA JR, M.; XAVIER, M. A. S.; FONTES, M. R. M.; GIGLIO, J. R.; FRANÇA, S. C. Analys of Bothrops jararacussu venomous gland transcriptome focusing on structural and functional aspects: I-gene expression profile of highly expressed phospholipases A2. Biochimie. 2004. 86:211-219.

KEOGH, J. S.; SHINE, R.; DONNELLAN, S. Phylogenetic relationships of terrestrial Australo-Papuan elapid snakes (subfamily Hydrophiinae) based on cytochrome b and 16S rRNA sequences. Mol. Phylogenet. Evol. 1998. 10(1):67-81.

KINI, R. M. Serine proteases affecting blood coagulation and fibrinolysis from snake venoms. Pathophysiol. Haemost. Thromb. 2005. 34(4-5):200-4.

KLINMAN, D.; YAMSHCHIKOV, G.; ISHIGATSUBO, Y. Contribution of CpG Motifs to the immunogenicity of DNA vaccines. J. Immunol. 1997. 158:3635-9.

KOCHOLATY, W. F.; LEDFORD, E. B.; DALY, J. G.; BILLINGS, T. A. Toxicity and some enzymatic properties and activities in the venoms of Crotalidae, Elapidae and Viperidae. Toxicon. 1971. 9(2):131-8.

KOMORI, Y.; NIKAI, T.; TANIGUCHI, K.; MASUDA, K.; SUGIHARA, H. Vascular endothelial growth factor VEGF-like heparin-binding protein from the venom of Vipera aspis aspis (Aspic Viper). Biochemistry. 1999. 38:11796-11803. 
KOSTIZA, T.; MEIER, J. Nerve growth factors from snake venoms: chemical properties, mode of action and biological significance. Toxicon. 1996. 34(7):787-806.

LAI, W. C.; BENNETT, M. DNA vaccines. Crit. Rev. Immunol. 1998. 18(5):449-84.

LAING, G. D.; COMPTON, S. J.; RAMACHANDRAN, R.; FULLER, G. L.; WILKINSON, M. C.; WAGSTAFF, S. C.; WATSON, S. P.; KAMIGUTI, A. S.; THEAKSTON, R. D.; SENIS, Y. A. Characterization of a novel protein from Proatheris superciliaris venom: proatherocytin, a 34-kDa platelet receptor PAR1 agonist. Toxicon. 2005. 46:490-499.

LAZO, G. R.; TONG, J.; MILLER, R.; HSIA, C.; RAUSCH, C.; KANG, Y.; ANDERSON, O. D. Software scripts for quality checking of high-throughput nucleic acid sequencers. Biotechniques. 2001. 30(6):1300-1305.

LEE, N. H.; WEINSTOCK, K. G.; KIRKNESS, E. F.; EARLE-HUGHES, J. A.; FULDNER, R. A.; MARMAROS, S.; GLODEK, A.; GOCAYNE, J. D.; ADAMS, M. D.; KERLAVAGE, A. R. et al. Comparative expressed-sequence-tag analysis of differential gene expression profiles in PC-12 cells before and after nerve growth factor treatment. Proc Natl Acad Sci USA. 1995. 92(18): 8303-8307.

LEWIN, B. Genes VII. Oxford: Oxford University Press, 2000. 990 p.

LIU, M. A. DNA vaccines: a review. Journal of Internal Medicine. 2003. 253(4):402-410.

MARQUES, O. A. V.; SAZIMA, I. Diet and feeding behavior of coral snake Micrurus corallinus, from Atlantic Forest of Brazil. Herpetol. Nat. History. 1997. 5(1):88-93.

McDOWALL, J. Snake Venom: Bungarotoxins. http://www.ebi.ac.uk/interpro/potm/2004_6/Page1.htm (acessado dia 7 de julho de 2006).

MEBS, D.; OWNBY, C. L. Myotoxic components of snake venoms: their biochemical and biological activities. Pharmacol Ther. 1990. 48(2):223-36. Review.

MÉNEZ, A.; BONTEMS, F.; ROUMESTAND, C.; GILQUIN, B.; TOMA, F. Structural basis for functional diversity of animal toxins. Proccedings of Royal Society of Edimburg. 1992. 99B(1/2): 83-103.

MORA, R.; VAlVERDE, B.; DÍAZ, C.; LOMONTE, B.; GUTIÉRREZ, J. M. A Lys49 phospholipase $A(2)$ homologue from Bothrops asper snake venom induces proliferation, apoptosis and necrosis in a lymphoblastoid cell line. Toxicon. 2005. 45(5):651-60. 
MOUSSATCHÉ, H.; YATES, A.; MELÉNDEZ, T.; MENDOZA, J. Preliminary report o the fractionation of the venom of Micrurus nigrocinctus and the pharmacological properties of the fractions. ABSTRACTS OF THE $5^{\mathrm{TH}}$ INTERNATIONAL SYMPOSIUM ON ANIMAL, PLANT AND MICROBIAL TOXINS. 1976; 60.

NAIR, D. G.; FRY, B. G.; ALEWOOD, P.; KUMAR, P. P.; KINI, R. M. Antimicrobial activity of omwaprin, a new member of the waprin family of snake venom proteins. Biochem. J. 2007. 402, 93-104 doi:10.1042/BJ2006031893

NATHAN, I.; DVILANSKY, A.; YIRMIYAHU, T.; AHARON, M.; LIVNE, A. Impairment of platelet aggregation by Echis colorata venom mediated by L-amino acid oxidase or $\mathbf{H}_{2} \mathbf{O}_{2}$. Thromb Haemost. 1982. 48(3):277-82.

NIRTHANAN, S.; GWEE, M. C. Three-finger alpha-neurotoxins and the nicotinic acetylcholine receptor, forty years on. J. Pharmacol. Sci. 2004. 94(1):1-17. Review.

OGAWA, T.; CHIJIWA, T.; ODA-UEDA, N.; OHNO, M. Molecular diversity and accelerated evolution of C-type lectin-like proteins from snake venom. Toxicon. 2005. 45(1):1-14. Review.

OLIVEIRA, S. C.; ROSINHA, G. M.; DE-BRITO, C. F.; AFONSO, R. R.; COSTA, M. C.; GOES, A. M. RECH, E. L., AZEVEDO, V. Immunological properties of gene vaccins delivered by different routes. Braz. I. Med. Biol. 1999. 32(2):207-14

PEARSON, A.; TYLER, M. I.; RETSON, K. V.; HOWDEN, M. E. H. Studies on the subunit structure of textilotoxin, a potent presynaptic neurotoxin from the venom of the Australian common brown snake (Pseudonaja textilis): The complete amino-acid sequences of all the subunits. Biochim. Biophys. Acta. 1993. 1161 223-229.

PRIETO DA SILVA, A. R.; YAMAGUSHI, I. K.; MORAIS, J. F.; HIGASHI, H. G.; RAW, I.; HO, P. L.; OLIVEIRA, J. S. Cross reactivity of different specific Micrurus antivenom sera with homologous and heterologous snake venoms. Toxicon. 2001a. 39(7):949-53.

PRIETO DA SILVA, A. R. B. Clonagem, expressão e estudo de alguns cDNAs codificando proteínas estruturalmente relacionadas às alfa neurotoxinas da glândula de veneno da cobra coral Micrurus corallinus (Serpentes, Elapidae). 2001b. Tese de doutorado. Departamento de Bioquímica do Instituto de Química da Universidade de São Paulo.

QINGHUA, L.; XIAOWEI, Z.; WEI, Y.; CHENJI, L.; YIJUN, H.; PENGXIN, Q.; XINGWEN, S.; SONGNIAN, H.; GUANGMEI, Y. A catalog for transcripts in the venom gland of 
the Agkistrodon acutus: identification of the toxins potentially involved in coagulopathy. Biochem. Biophys. Res. Commun. 2006. 341(2):522-31.

RAIBEKAS, A. A.; MASSEY, V. Primary structure of the snake venom L-amino acid oxidase shows high homology with the mouse B cell interleukin 4-induced Fig1 protein. Biochem. Biophys. Res. Commun.. 1998. 248(3):476-8.

RAWEERITH, R.; RATANABANANGKOON, K. Immunochemical and biochemical comparisons of equine monovalent and polyvalent snake antivenoms. Toxicon. 2005. 45:369-375.

ROSSETTO, O.; MORBIATO, L.; CACCIN, P.; RIGONI, M.; MONTECUCCO, C. Presynaptic enzymatic neurotoxins. J. Neurochem. 2006. 97(6):1534-45.

ROZE, J.A. Summary of coral snakes (Elapidae) from Cerro de La Neblina, Venezuela, with description of a new subspecies. Rev. Fr. Aquariol. Herpetol. 1987. 14:109-112.

SAMBROOK, J.; FRITSCH, E. F.; MANIATIS, T. Molecular cloning: A laboratory manual. 3 vols. Cold Spring Harbour: Laboratory Press, 1989.

SCHWEITZ, H.; VIGNE, P.; MOINIER, D.; FRELIN, C.; LAZDUNSKI, M. A new member of the natriuretic peptide family is present in the venom of the green mamba (Dendroaspis angusticeps). J. Biol. Chem. 1992. 267(20):13928-32.

SERRANO, S. M., MAROUN, R. C. Snake venom serine proteinases: Sequence homology vs. substrate specificity, a paradox to be solved. Toxicon. 2005. 45:1115-1132.

SLOWINSKI, J. B. A phylogenetic analysis of new world coral snakes (Elapidae: Leptomicrurus, Micruroides and Micrurus) based on allozymic and morphological characters. J. Herptol. 1995. 29:325-38.

SLOWINSKI, J. B.; KNIGHT, A.; ROONEY, A.P. Inferring species trees from gene trees: a phylogenetic analysis of the Elapidae (Serpentes) based on the amino acid sequences of venom proteins. Mol. Phylogenet. Evol. 1997. 8(3):349-62.

SOARES, M. B. "Construction of directionally cloned cDNA libraries in phagenid vectors." In: ADAMS, M.; FIELDS, C.; VENTER, J. C. Automated DNA sequencing and analysis techniques. Londres: Academic Press, 1994. pp. 110-114. 
STRYDOM, D. J. Snake venom toxins: The amino-acid sequence of a short-neurotoxin homologue from Dendroaspis polylepis polylepis (black mamba) venom. Eur. J. Biochem. 1977. 76(1):99-106.

TAMIYA, T.; LAMOUROUX, A.; JULIEN, S. F.; GRIMA, B.; MALLET, S.; FROMAGEOT, P.; MÉNEZ, A. Cloning and sequence analysis of the cDNA encoding a snake neurotoxin precursor. Biochimie. 1985. 67:185-189.

TANG, D. C.; DEVIT, M.; JOHNSTON, S. A. Genetic immunization is a simple method for eliciting an immune response. Nature. 1992. 356(6365):152-4.

TANJONI, I.; BUTERA, D.; BENTO, L.; DELLA-CASA, M. S; MARQUES-PORTO, R.; TAKEHARA, H. A.; GUTIERREZ, J. M.; FERNANDES, I.; MOURA-DA-SILVA, A. M. Snake venom metalloproteinases: structure/function relationships studies using monoclonal antibodies. Toxicon. 2003. 42(7):801-8.

TORRES, A. M.; WONG, H. Y.; DESAI, M.; MOOCHHALA, S.; KUCHEL, P. W.; KINI, R. M. Identification of a novel family of proteins in snake venoms. Purification and structural characterization of nawaprin from Naja nigricollis snake venom. J. Biol. Chem. 2003. 278(41):40097-104.

TOULON, M.; PALFREE, R. G.; PALFREE, S.; DUMONT, F. J.; HÄMMERLING, U. Ly-6 A/E antigen of murine $T$ cells is associated with a distinct pathway of activation: Requirements for interferon and exogenous interleukin 2. Eur. J. Immunol. 1988. 18(6):937-42.

TSETLIN, V. Snake venom alpha-neurotoxins and other 'three-finger' proteins. Eur. $J$. Biochem. 1999. 264(2):281-6. Review.

ULMER, J. B.; DeWITT, C. M., CHASTAIN, M. et al. Enhancement of DNA vaccine potency using conventional aluminum adjuvants. Vaccine. 1999. 18:18-28.

VITAL BRAZIL, O. Veneneos ofídicos neurotóxicos. Ver Ass. Med. Bras., 26:212-218. 1980

VITAL BRAZIL, O.; FONTANA, M. D. Ações pré-juncionais e pós-juncionais da peçonha da cobra coral Micrurus corallinus na junção neuromuscular. Mem. Inst. Butantan. 1983/84. 40/41:221-240.

VITAL BRAZIL, O. Coral snake venoms: Model of action and pathophysiology of experimental envenomation. Rev. Inst. Med. trop São Paulo, 1987;29-119. 
WAGSTAFF, S. C; HARRISON, R. A. Venom gland EST analysis of the saw-scaled viper, Echis ocellatus, reveals novel alpha9beta1 integrin-binding motifs in venom metalloproteinases and a new group of putative toxins, renin-like aspartic proteases. Gene. 2006. 377:21-32.

WAGSTAFF, S. C.; FAVREAU, P.; ChENEVAL, O.; LAING, G. D.; WILKINSON, M. C.; MILLER. R. L.; STÖCKLIN, R.; HARRISON, R. A. Molecular characterisation of endogenous snake venom metalloproteinase inhibitors. Biochem. Biophys. Res. Commun. 2008. 365(4):650-6.

WARREL, D. A. "Geographical intraspecies variation in the clinical manifestation of envenoming by snakes.” In: Venomous snakes: ecology, evolution and snakes bites. Oxford: Claredon Press, 1997. Pp. 189-204.

WEIS, W. I.; TAYLOR, M. E.; DRICKAMER, K. The C-type lectin superfamily in the immune system. Immunol. Rev. 1998. 163:19-34. Review.

WOODARD, G. E.; ROSADO, J. A.; BROWN, J. Dendroaspis natriuretic peptide-like immunoreactivity and its regulation in rat aortic vascular smooth muscle. Peptides. 2002. 23:23-29.

YEE, J. S. P.; NANLING, G.; AFIFIYAN, F.; DONGHUI, M.; LAY, P. S.; ARMUGAN, A.; JEYASEELAN, K. Snake postsynaptic neurotoxins: gene structure, phylogeny and applications in research and therapy. Biochimie. 2004. 86:137-149.

ZUPUNSKI, V.; KORDIS. D.; GUBENSEK, F. Adaptive evolution in the snake venom Kunitz/BPTI protein family. FEBS Lett. 2003. 547(1-3):131-6. 


\section{BIOGRAFIA}

\section{LUCIANA IWANAGA LEÃO}

\section{Formação Acadêmica}

- Bacharel em Ciências Biológicas pela Universidade de São Paulo (2001-2005)

- Licenciatura pela Faculdade de Educação da Universidade de São Paulo (2004-2006)

- Pós-graduação pelo Departamento de Genética e Biologia Evolutiva da Universidade de São

Paulo (2006-2008)

\section{Atuação Profissional}

\section{8}

Professora de ensino fundamental I e II, ensino médio e curso pré-vestibular no EMAE do GRAACC (Grupo de Apoio ao Adolescente e Criança com Câncer)

\section{6-2008}

Mestrado no Centro de Biotecnologia do Instituto Butantan - Geração de um banco transcriptômico de glândulas de veneno de Micrurus corallinus e identificação de candidatos antigênicos para um anti-soro antielapídico.

\section{3-2005}

Iniciação Científica no Centro de Biotecnologia do Instituto Butantan - Geração e análise de um banco representativo de cDNAs de Bothrops insularis.

\section{1-2003}

Iniciação Científica no Departamento de Bioquímica e Fisiologia Animal da UNIFESP Estudo sobre a ação de enzimas hepáticas em fígado perfundido de rato.

\section{Trabalhos apresentados em Congressos}

LEÃO LI, Ho PL, Junqueira de Azevedo ILM. Identification of putative antigenic candidates to an antielapidic serum based on the analysis of Micrurus corallinus transcriptome. 2008. 33rd FEBS Congress \& 11th IUBMB Conference. Atenas, Grécia.

LEÃO LI, Ho PL, Junqueira de Azevedo ILM. Identification of putative antigenic candidates to an antielapidic serum based on the analysis of Micrurus corallinus transcriptome. 2008. XXXVII Reunião Anual da Sociedade Brasileira de Bioquímica e Biologia Molecular (SBBq) e XI Reunião da Panamerican Association for Biochemistry and Molecular Biology (PABMB). Águas de Lindóia, São Paulo. 
LEÃO LI, Ho PL, Junqueira de Azevedo ILM. The analysis of Micrurus corallinus (coralsnake) transcriptome. 2007. XXXVI Reunião Anual da Sociedade Brasileira de Bioquímica e Biologia Molecular - Sbbq e 10th International Union of Biochemistry and Molecular Biology Conference (IUBMB). Salvador, Bahia.

Ramos-Guimarães, P ; Oliveira-Carvalho, A.L ; Correa-Neto, C ; Aguiar, A. S. ; Melgarejo, A.R. ; LEÃO, L. I.; Junqueira-de-Azevedo, I. L. M.; Ho, PL ; Soares, MR ; Zingali, R.B. Predictive proteome of Micrurus frontalis versus Micrurus corallinus venom. 2007. 9th IST Pan-American Section Meeting, Mexico.

LEÃO LI, Ho PL, Junqueira de Azevedo ILM. Identification of putative antigenic candidates to an antielapidic serum based on the analysis of Micrurus corallinus transcriptome. 2006. VIII Reunião Anual Do Instituto Butantan. São Paulo.

LEÃO LI, Ho PL, Junqueira de Azevedo ILM. Identification of putative antigenic candidates to an antielapidic serum based on the analysis of Micrurus corallinus transcriptome. 2006. IX Congresso Brasileiro de Toxinologia - SBTx. Fortaleza, Ceará.

LEÃO LI, Ho PL, Junqueira de Azevedo ILM. A full-length set of ORFs from Bothrops insularis transcriptome and a comparative view of Viperidae envenoming through major toxin profile. 2005. XXXIV Reunião Anual da Sociedade Brasileira de Bioquímica e Biologia Molecular - SBBq. Águas de Lindóia, São Paulo.

LEÃO LI, Ho PL, Junqueira de Azevedo ILM. The generation and analysis of a cDNA database of Bothrops insularis venom glands, focusing on identification of new toxins and the characterization of the full-lenght sequences of some transcripts. 2005. VII Reunião Anual Científica do Instituto Butantan. São Paulo.

LEÃO LI, Junqueira de Azevedo ILM, Nishiyama MYJr, Ho PL. The generation and analysis of a cDNA database of Bothrops insularis venom glands, focusing on identification of new toxins and the characterization of the full-lenght sequences of some transcripts. 2004. VI Reunião Científica Anual do Instituto Butantan. São Paulo.

LEÃO LI, Ho PL, Junqueira de Azevedo ILM. The Bothrops insularis Transcriptome Project: The Generation And Analysis Of An Updated Expressed Sequence Tags (ESTs) Database. 2004. VIII Congresso da Sociedade Brasileira de Toxinologia.VIII Congresso da Sociedade Brasileira de Toxinologia. Angra dos Reis, Rio de Janeiro.

LEÃO LI, Borges DR. Influência da Idade na Resposta à Agressão Hepática por Diferentes Agentes. 2003. PIBIC. São Paulo.

\section{Artigos aceitos para publicação}

Batista IFC, Chudzinski-Tavassi AM,Faria F, Simons SM, Labruna MB, Barros-Batestti DM; LEÃO LI, Ho PL, Junqueira de Azevedo ILM. Expressed Sequence Tags (ESTs) from the salivary glands of the tick Amblyomma cajennense (Acari: Ixodidae). Toxicon. 2007. 


\section{Outras atividades}

Análise das metaloproteases de Bothrops insularis

No projeto de inciação científica, o banco transcriptômico de B. insularis foi ampliado para 2 mil ESTs. Durante o período das pesquisas com M. corallinus, foi realizado o seqüenciamento completo de metaloproteases e serinoproteases presentes na glândula de veneno de B. insularis, que correspondia à continuidade do projeto desenvolvido durante a Iniciação Científica (IC 04/10803-4).

\section{Transcriptoma de Amblyomma cajennense}

Participação nas etapas técnicas desse projeto, com a geração de 1800 ESTs. Participação também na anotação e análise do banco de transcriptoma do carrapato Amblyomma cajennense, projeto em colaboração com o Dr. Paulo Lee Ho (Centro de Biotecnologia) e a Dra. Isabel F. Batista (Laboratório de Bioquímica). Já havia participado. As seqüências foram depositadas no dbEST do GenBank.

\section{Projeto Butantan na Amazônia}

Participação, no mês de setembro de 2006, do workshop e palestras nas Faculdades Integradas do Tapajós (FIT), dedicados aos alunos, professores e profissionais da região a fim de iniciar um primeiro contato do Instituto Butantan com a população local de Santarém. O projeto tem o intuito de formar mestres e doutores na região de Santarém, criando um programa de pósgraduação orientado pelo Instituto, que ocorrerá em parceria com as faculdades locais. As pesquisas serão realizadas na Base Avançada que será construída pelo Instituto Butantan na cidade de Belterra.

Participação como monitora, por indicação do Dr. Giuseppe Puorto (diretor do Museu do Instituto Butantan), dos cursos oferecidos às populações ribeirinhas do Rio Tapajós e Rio Amazonas, assim como às populações locais de Belterra e Alter do Chão.

\section{Proteômica das glândulas de veneno de Bothrops insularis}

Colaboração com dados sobre o transcriptoma de glândulas de veneno de B. insularis para pesquisa proteômica do Dr. Richard Hemmi Valente e Dr. Gilberto Domont, do Rio de Janeiro (FIOCRUZ). Um artigo científico unindo os dados transcriptômicos e proteômicos está sendo submetido à publicação no presente momento. 
Tabela 8: Tabela de anotação - representa todo o perfil transcriptômico de clusters obtidos a partir da geração de ESTs de glândulas de veneno de Micrurus corallinus .

\begin{tabular}{|c|c|c|c|c|c|c|c|c|c|c|}
\hline CLUSTER & Tamanho (pb) & $\begin{array}{c}N^{\circ} \text { de Clones } \\
\text { no Cluster }\end{array}$ & FULL & $\begin{array}{c}\text { Categoria } \\
\text { 1aria }\end{array}$ & PRODUTO & Blast & Accession $\mathrm{N}^{\circ}$ & $\%$ ID & e-value & overlap \\
\hline MCOR0001C & 551 & 6 & $\mathrm{FF}$ & TB & natriuretic peptide & $x$ & $>\mathrm{gb}|\mathrm{AAC} 60341.1|$ & 99 & 4.00E-73 & $138 / 139$ \\
\hline MCOR0002C & 573 & 2 & $P$ & UF & similar to Hypothetical protein CGI-99 & $x$ & >ref|XP_217550.2| & 81 & $2.00 \mathrm{E}-80$ & $146 / 179$ \\
\hline MCOR0003C & 868 & 3 & $\mathrm{FP}$ & $\mathrm{CM}$ & Eno3-prov protein & $x$ & $>\mathrm{gb}|\mathrm{AAH} 45082.1|$ & 92 & E-141 & $251 / 271$ \\
\hline MCOR0004C & 435 & 35 & FF & TNtx & Alpha-neurotoxin homolog 7 precursor & $x$ & sp|Q9PRI1|NXAH7_MICCO & 100 & $4.00 \mathrm{E}-41$ & $78 / 78$ \\
\hline MCOR0005C & 541 & 2 & FP & OF & II-FBPL precursor & $x$ & $>g b|A B B 30003.1|$ & 39 & $2.00 \mathrm{E}-22$ & $58 / 148$ \\
\hline MCOR0006C & 870 & 5 & $P$ & $\mathrm{CT}$ & $60 S$ acidic ribosomal protein P0 (L10E) & $x$ & sp|P47826|RLA0_CHICK & 94 & $E-131$ & $240 / 254$ \\
\hline MCOR0007C & 1028 & 21 & $\mathrm{FF}$ & $\mathrm{CM}$ & (GAPDH) homologue & $x$ & dbj|BAD74117.1| & 91 & $\mathrm{E}-171$ & $294 / 322$ \\
\hline MCOR0008C & 876 & 5 & $\mathrm{FP}$ & $\mathrm{CE}$ & alpha skeletal actin precursor & $x$ & ref|NP_776650.1| & 100 & $\mathrm{E}-157$ & $275 / 275$ \\
\hline MCOR0009C & 952 & 4 & $P$ & MT & Dinodon mitochondrion, complete genome & & $>$ ref|NC_001945.1| & 88 & $8.00 \mathrm{E}-81$ & $256 / 290$ \\
\hline MCOR0010C & 524 & 2 & & $\mathrm{NH}$ & no hit & & & & & \\
\hline MCOR0011C & 671 & 26 & $\mathrm{FP}$ & CT & similar to $60 \mathrm{~S}$ acidic ribosomal protein P0 & $x$ & ref|XP_850994.1| & 99 & E-108 & 199/201 \\
\hline MCOR0012C & 682 & 2 & $\mathrm{FP}$ & CT & Elongation factor 1-gamma (EF-1-gamma) & $x$ & sp|Q68FR6|EF1G_RAT & 84 & $\mathrm{E}-110$ & $190 / 225$ \\
\hline MCOR0013C & 602 & 6 & FP & $\mathrm{CT}$ & $40 S$ ribosomal protein $\mathrm{S} 5$ & $x$ & >gb|AAP20199.1| & 97 & $1.00 \mathrm{E}-94$ & $171 / 176$ \\
\hline MCOR0014C & 827 & 5 & $\mathrm{FF}$ & MT & Dinodon mitochondrion, complete genome & $x$ & sp|O79551|ATP6_DINSE & 69 & $1.00 \mathrm{E}-83$ & $158 / 226$ \\
\hline MCOR0015C & 689 & 3 & $P$ & UF & $55 \mathrm{kDa}$ erythrocyte membrane protein & $x$ & dbj|BAD97116.1| & 77 & 4.00E-52 & $98 / 127$ \\
\hline MCOR0016C & 522 & 2 & & $\mathrm{NH}$ & no hit & & & & & \\
\hline MCOR0017C & 858 & 6 & FP & $\mathrm{CM}$ & ornithine decarboxylase antizyme - human & $x$ & $\mathrm{gb}|\mathrm{AAA} 82155.1|$ & 70 & $5.00 \mathrm{E}-64$ & $125 / 177$ \\
\hline MCOR0018C & 790 & 2 & $P$ & $\mathrm{CR}$ & Alpi-prov protein & $x$ & >gb|AAH89726.1| & 55 & $5.00 \mathrm{E}-15$ & $44 / 80$ \\
\hline MCOR0019C & 474 & 5 & $\mathrm{FP}$ & TB & natriuretic peptide & $x$ & $>\mathrm{gb}|\mathrm{AAC} 60341.1|$ & 89 & $1.00 \mathrm{E}-21$ & $53 / 59$ \\
\hline MCOR0020C & 549 & 2 & $\mathrm{FF}$ & OF & Hemoglobin alpha-A subunit & $\mathrm{x}$ & sp|P0COU6|HBA_DRYCE & 88 & $6.00 \mathrm{E}-64$ & $121 / 137$ \\
\hline MCOR0021C & 564 & 7 & FP & $\mathrm{CT}$ & Similar to ribosomal protein S3 & $x$ & $>\mathrm{gb}|\mathrm{AAH} 41299.1|$ & 99 & $2.00 \mathrm{E}-96$ & $182 / 183$ \\
\hline MCOR0022C & 441 & 2 & FP & CE & similar to Troponin C & $x$ & dbj|BAD14398.1| & 92 & $2.00 \mathrm{E}-68$ & $130 / 140$ \\
\hline
\end{tabular}




\begin{tabular}{|c|c|c|c|c|c|c|c|c|c|c|}
\hline CLUSTER & Tamanho (pb) & $\begin{array}{c}N^{\circ} \text { de Clones } \\
\text { no Cluster }\end{array}$ & FULL & $\begin{array}{c}\text { Categoria } \\
\text { 1aria }\end{array}$ & PRODUTO & Blast & Accession $\mathrm{N}^{\circ}$ & $\%$ ID & e-value & overlap \\
\hline MCOR0023C & 485 & 2 & $P$ & $C D$ & ubiquitin $\mathrm{C}$ & $x$ & $>\mathrm{gb}|\mathrm{ABC} 94632.1|$ & 72 & $2.00 \mathrm{E}-46$ & $108 / 149$ \\
\hline MCOR0024C & 535 & 3 & $\mathrm{FF}$ & $\mathrm{TL}$ & C-type lectin-like protein 2 & $x$ & gb|AAK43585.1| & 40 & $2.00 \mathrm{E}-27$ & $64 / 158$ \\
\hline MCOR0025C & 477 & 2 & $\mathrm{FP}$ & $\mathrm{CT}$ & similar to ribosomal protein $\mathrm{L} 13$ & $x$ & gb|AAH93063.1| & 91 & $1.00 \mathrm{E}-71$ & $129 / 141$ \\
\hline MCOR0026C & 940 & 3 & $\mathrm{FF}$ & $\mathrm{CP}$ & signal sequence receptor, beta & $x$ & >ref|NP_001006561.1| & 92 & $6.00 \mathrm{E}-92$ & $167 / 181$ \\
\hline MCOR0027C & 914 & 4 & $\mathrm{FP}$ & $\mathrm{CT}$ & ribosomal protein $L 4$ & $x$ & ref|NP_001007480.1| & 95 & $E-163$ & $277 / 289$ \\
\hline MCOR0028C & 825 & 4 & $\mathrm{FP}$ & $\mathrm{CT}$ & $60 S$ ribosomal protein $\mathrm{L} 5$ & $x$ & sp|P22451|RL5_CHICK & 96 & $E-144$ & $249 / 259$ \\
\hline MCOR0029C & 538 & 2 & $\mathrm{FP}$ & $C D$ & Proteasome (prosome, macropain) & $x$ & ref|NP_989113.1| & 96 & $7.00 \mathrm{E}-80$ & $144 / 149$ \\
\hline MCOR0030C & 623 & 3 & $\mathrm{FP}$ & $\mathrm{CP}$ & Protein disulfide-isomerase precursor PDI & $x$ & $>g b|A A Y 33972.1|$ & 93 & $1.00 \mathrm{E}-95$ & $174 / 186$ \\
\hline MCOR0031C & 986 & 3 & $P$ & $\mathrm{CE}$ & superfast myosin heavy chain & $x$ & ref|NP_001009221.1| & 85 & $E-148$ & $268 / 312$ \\
\hline MCOR0032C & 869 & 3 & $\mathrm{FP}$ & $C D$ & Proteasome activator complex subunit 1 & $x$ & sp|Q4U5R3|PSME1_BOVIN & 63 & $8.00 \mathrm{E}-86$ & $156 / 245$ \\
\hline MCOR0033C & 577 & 2 & $\mathrm{FP}$ & $\mathrm{CE}$ & similar to Actin, cytoplasmic 2 & $x$ & sp|P63260|ACTG_MOUSE & 100 & $4.00 \mathrm{E}-92$ & $165 / 165$ \\
\hline MCOR0034C & 522 & 2 & $\mathrm{FP}$ & CT & similar to Elongation & $x$ & >ref|XP_884705.1| & 60 & $1.00 \mathrm{E}-42$ & $92 / 151$ \\
\hline MCOR0035C & 721 & 20 & FF & TNtx & Short neurotoxin 3 precursor & $x$ & sp|Q9W7K0|NXS3_PSETE & 53 & $2.00 \mathrm{E}-15$ & $43 / 80$ \\
\hline MCOR0036C & 698 & 196 & $\mathrm{FF}$ & TP & phospholipase A2 & $x$ & gb|AAN60018.1| & 100 & $2.00 \mathrm{E}-86$ & $146 / 146$ \\
\hline MCOR0037C & 597 & 2 & $P$ & MT & NADH dehydrogenase subunit 4 & $x$ & ref|YP_313690.1| & 80 & $2.00 \mathrm{E}-88$ & $161 / 199$ \\
\hline MCOR0038C & 625 & 2 & $P$ & CT & ribosomal protein L6 & $x$ & ref|NP_989483.1| & 87 & 7.00E-99 & $176 / 202$ \\
\hline MCOR0039C & 486 & 29 & FF & TNtx & Short neurotoxin homolog NTL4 & $x$ & sp|Q9YGI8|NXSH4_BUNMU & 61 & $1.00 \mathrm{E}-26$ & $53 / 86$ \\
\hline MCOR0040C & 611 & 3 & $P$ & $\mathrm{CT}$ & eukaryotic translation initiation factor & $x$ & ref|XP_213456.2| & 86 & 3.00E-61 & $118 / 137$ \\
\hline MCOR0041C & 559 & 2 & $P$ & $\mathrm{CM}$ & similar to isocitrate dehydrogenase 2 & $x$ & ref|XP_536192.2| & 91 & E-102 & $171 / 186$ \\
\hline MCOR0042C & 833 & 2 & $P$ & CE & Keratin, type I cytoskeletal 15 & $x$ & sp|Q6IFV3|K1C15_RAT & 78 & E-122 & $216 / 276$ \\
\hline MCOR0043C & 711 & 2 & & $\mathrm{NH}$ & no hit & & & & & \\
\hline MCOR0044C & 648 & 2 & $P$ & OF & similar to selenophosphate synthetase & $x$ & ref $\left|X P \_870912.1\right|$ & 83 & $1.00 \mathrm{E}-48$ & $102 / 122$ \\
\hline MCOR0045C & 766 & 8 & $P$ & $\mathrm{CR}$ & similar to guanine nucleotide binding protein & $x$ & $>\mathrm{gb}|\mathrm{AAO} 21313.1|$ & 97 & $E-132$ & $229 / 234$ \\
\hline MCOR0046C & 673 & 2 & $\mathrm{FP}$ & MT & NADH dehydrogenase subunit 1 & $x$ & $>\mathrm{gb}|\mathrm{AAL} 66854.1|$ & 88 & $E-106$ & $195 / 220$ \\
\hline
\end{tabular}




\begin{tabular}{|c|c|c|c|c|c|c|c|c|c|c|}
\hline CLUSTER & Tamanho (pb) & $\begin{array}{c}N^{\circ} \text { de Clones } \\
\text { no Cluster }\end{array}$ & FULL & $\begin{array}{c}\text { Categoria } \\
\text { 1aria }\end{array}$ & PRODUTO & Blast & Accession $\mathrm{N}^{\circ}$ & $\%$ ID & e-value & overlap \\
\hline MCOR0047C & 681 & 2 & $P$ & $\mathrm{CT}$ & $40 S$ ribosomal protein $\mathrm{S} 2$ & $x$ & $\mathrm{gb}|A A Z 38987.1|$ & 99 & $\mathrm{E}-125$ & $224 / 226$ \\
\hline MCOR0048S & 449 & 1 & $P$ & $C D$ & ubiquitin & $x$ & $>g b|A A V 84266.1|$ & 99 & $6.00 \mathrm{E}-77$ & $148 / 149$ \\
\hline MCOR0049C & 547 & 4 & $\mathrm{FP}$ & CT & Ribosomal protein S6 & $\mathrm{x}$ & gb|AAH27620.1| & 95 & 7.00E-91 & $164 / 172$ \\
\hline MCOR0050C & 443 & 2 & $\mathrm{FP}$ & OF & Ferritin light chain, oocyte isoform (B-ferritin) & $\mathrm{x}$ & sp|Q7SXA5|FRIL_XENLA & 68 & $3.00 \mathrm{E}-35$ & $73 / 106$ \\
\hline MCOR0051C & 745 & 2 & $P$ & $\mathrm{CP}$ & Coatomer subunit delta (Delta-coat protein) & $x$ & >emb|CAA57072.1| & 86 & $3.00 \mathrm{E}-13$ & $38 / 44$ \\
\hline MCOR0052C & 491 & 3 & $P$ & CT & similar to $\mathrm{K} 123$ protein & $x$ & >ref|NP_990350.1| & 51 & $1.00 \mathrm{E}-15$ & $45 / 88$ \\
\hline MCOR0053C & 564 & 3 & $\mathrm{FF}$ & OF & Defender against cell death 1 (DAD-1) & $x$ & sp|O13113|DAD1_CHICK & 90 & $4.00 \mathrm{E}-55$ & $112 / 124$ \\
\hline MCOR0054C & 544 & 2 & $P$ & MT & cytochrome oxidase subunit 1 & $\mathrm{x}$ & >ref|YP_313683.1| & 81 & 7.00E-61 & $105 / 129$ \\
\hline MCOR0055C & 537 & 2 & $\mathrm{FF}$ & UF & MGC52838 protein & $\mathrm{x}$ & $>g b|A A| 06323.1 \mid$ & 76 & $3.00 \mathrm{E}-47$ & $87 / 114$ \\
\hline MCOR0056C & 559 & 2 & FP & CT & similar to ribosomal protein S9-like & $x$ & sp|Q6ZWN5|RS9_MOUSE & 99 & $1.00 \mathrm{E}-92$ & $172 / 173$ \\
\hline MCOR0057C & 757 & 5 & $\mathrm{FP}$ & CT & $40 S$ ribosomal protein $\mathrm{S} 4$ & $\mathrm{x}$ & sp|P47836|RS4_CHICK & 98 & $\mathrm{E}-142$ & $248 / 252$ \\
\hline MCOR0058C & 548 & 4 & $\mathrm{FP}$ & CE & Alpha crystallin B chain (Alpha(B)-crystallin) & $\mathrm{x}$ & sp|P41316|CRYAB_RABIT & 62 & $1.00 \mathrm{E}-47$ & $100 / 160$ \\
\hline MCOR0059C & 581 & 6 & $\mathrm{FP}$ & CT & Eukaryotic translation elongation factor & $\mathrm{x}$ & sp|P24534|EF1B_HUMAN & 88 & $3.00 \mathrm{E}-81$ & $149 / 169$ \\
\hline MCOR0060C & 566 & 4 & $\mathrm{FF}$ & TL & C-type lectin-like protein 2 & $x$ & $>g b|A A K 43585.1|$ & 42 & $1.00 \mathrm{E}-31$ & $67 / 156$ \\
\hline MCOR0061C & 541 & 2 & $\mathrm{FP}$ & CE & tropomyosin alpha striated muscle isoform & $x$ & >gb|AAT68295.1| & 94 & $1.00 \mathrm{E}-76$ & $153 / 162$ \\
\hline MCOR0062C & 646 & 2 & FF & UF & SH3 domain binding glutamic acid-rich & $\mathrm{x}$ & ref|XP_216547.1| & 86 & $5.00 \mathrm{E}-39$ & $80 / 93$ \\
\hline MCOR0063C & 1123 & 4 & $P$ & TM & cobrin precursor & $\mathrm{x}$ & gb|AAF00693.1| & 82 & 0.0 & $305 / 370$ \\
\hline MCOR0064C & 556 & 2 & $P$ & CR & Breast cancer metastasis-suppressor 1 & $x$ & sp|Q9HCU9|BRMS1_HUMAN & 67 & $6.00 \mathrm{E}-69$ & $125 / 184$ \\
\hline MCOR0065C & 572 & 3 & $\mathrm{FP}$ & CT & similar to $60 S$ ribosomal protein L8 isoform & $x$ & sp|P62917|RL8_HUMAN & 98 & $E-101$ & $182 / 185$ \\
\hline MCOR0066C & 606 & 2 & $P$ & $\mathrm{CP}$ & hypoxia up-regulated 1 & $\mathrm{x}$ & >ref|NP_001006588.1| & 67 & $2.00 \mathrm{E}-70$ & $140 / 207$ \\
\hline MCOR0067C & 572 & 3 & $P$ & TL & Lithostathine 2 precursor & $\mathrm{x}$ & sp|Q08731|LIT2_MOUSE & 34 & $8.00 \mathrm{E}-16$ & $53 / 155$ \\
\hline MCOR0068C & 869 & 4 & FP & $\mathrm{CR}$ & similar to CAVP-target protein (CAVPT) & $\mathrm{x}$ & $>$ ref $\left|X P \_516109.1\right|$ & 70 & $2.00 \mathrm{E}-88$ & $165 / 234$ \\
\hline MCOR0069C & 566 & 2 & $P$ & $\mathrm{CM}$ & similar to ATP synthase, $\mathrm{H}+$ transporting & $x$ & $>$ ref $\left|X P \_858232.1\right|$ & 81 & 7.00E-76 & $143 / 175$ \\
\hline MCOR0070C & 540 & 2 & $P$ & CT & similar to $40 \mathrm{~S}$ ribosomal protein S8 & $x$ & $>$ ref $\left|X P \_422423.1\right|$ & 96 & 8.00E-98 & $171 / 177$ \\
\hline
\end{tabular}




\begin{tabular}{|c|c|c|c|c|c|c|c|c|c|c|}
\hline CLUSTER & Tamanho (pb) & $\begin{array}{c}N^{\circ} \text { de Clones } \\
\text { no Cluster }\end{array}$ & FULL & $\begin{array}{l}\text { Categoria } \\
\text { 1aria }\end{array}$ & PRODUTO & Blast & Accession $\mathrm{N}^{\circ}$ & $\%$ ID & e-value & overlap \\
\hline MCOR0071C & 618 & 2 & $P$ & $\mathrm{CR}$ & Actin-related protein $2 / 3$ complex & $x$ & sp|O15144|ARPC2_HUMAN & 97 & $6.00 \mathrm{E}-47$ & $91 / 93$ \\
\hline MCOR0072C & 897 & 6 & $P$ & $\mathrm{CR}$ & ADP/ATP translocase 2 & $x$ & sp|P05141|ADT2_HUMAN & 96 & E-142 & $245 / 255$ \\
\hline MCOR0073C & 2458 & 39 & FF & MT & Cytochrome $\mathrm{c}$ oxidase subunit 1 & $\mathrm{x}$ & sp|O79548|COX1_DINSE & 88 & 0.0 & $470 / 530$ \\
\hline MCOR0074C & 515 & 2 & $P$ & $\mathrm{CR}$ & TRIM5/cyclophilin A V4 fusion protein & $\mathrm{x}$ & $>$ gb|AAT99909.1| & 88 & $2.00 \mathrm{E}-71$ & $124 / 140$ \\
\hline MCOR0075C & 779 & 7 & FF & MT & Cytochrome $\mathrm{c}$ oxidase subunit 3 & $\mathrm{x}$ & sp|O79552|COX3_DINSE & 82 & $E-116$ & $207 / 251$ \\
\hline MCOR0076C & 1473 & 15 & $\mathrm{FF}$ & $\mathrm{CM}$ & similar to Fructose-bisphosphate aldolase $\mathrm{A}$ & $x$ & $>$ ref $\left|X P \_586556.2\right|$ & 90 & 0.0 & $328 / 364$ \\
\hline MCOR0077C & 557 & 4 & FF & TL & stejaggregin-A alpha chain & $\mathrm{x}$ & $>\mathrm{gb}|\mathrm{AAQ} 15166.1|$ & 44 & $2.00 \mathrm{E}-32$ & $72 / 163$ \\
\hline MCOR0078C & 486 & 2 & $P$ & $\mathrm{CR}$ & GNB2L1 protein & $\mathrm{x}$ & gb|AAI02287.1| & 99 & $3.00 \mathrm{E}-82$ & $147 / 148$ \\
\hline MCOR0079C & 614 & 2 & & $\mathrm{NH}$ & no hit & & & & & \\
\hline MCOR0080C & 528 & 2 & $P$ & OF & Scaffold attachment factor B & $x$ & $>$ ref $\left|X P \_542146.2\right|$ & 65 & $5.00 \mathrm{E}-62$ & $117 / 178$ \\
\hline MCOR0081C & 802 & 2 & $P$ & $C D$ & similar to X-prolyl aminopeptidase 2 & $\mathrm{x}$ & $>$ ref $\left|X P \_420139.1\right|$ & 61 & $2.00 \mathrm{E}-27$ & $64 / 104$ \\
\hline MCOR0082C & 669 & 5 & $P$ & MT & Naja naja $12 S$ ribosomal RNA gene & N & $>\mathrm{gb}|\mathrm{AF} 236683.2| \mathrm{AF} 236683$ & 91 & E-119 & $315 / 344$ \\
\hline MCOR0083C & 484 & 5 & $\mathrm{FF}$ & CT & $60 S$ acidic ribosomal protein $\mathrm{P} 1$ & $x$ & sp|P18660|RLA1_CHICK & 92 & $1.00 \mathrm{E}-53$ & $106 / 114$ \\
\hline MCOR0084C & 515 & 2 & $P$ & $C D$ & polyubiquitin $\mathrm{C}$ & $x$ & ref|NP_062613.2| & 60 & $2.00 \mathrm{E}-37$ & $94 / 155$ \\
\hline MCOR0085C & 981 & 5 & FF & CT & $40 S$ ribosomal protein SA ( $p 40)$ & $\mathrm{x}$ & sp|P50890|RSSA_CHICK & 96 & E-167 & $287 / 296$ \\
\hline MCOR0086C & 453 & 3 & $\mathrm{FF}$ & CT & $40 S$ ribosomal protein S27 & $x$ & sp|P42677|RS27_HUMAN & 100 & $8.00 \mathrm{E}-45$ & $84 / 84$ \\
\hline MCOR0087C & 1005 & 4 & $P$ & CT & eukaryotic translation elongation factor 1 & $\mathrm{x}$ & ref|NP_001013122.1| & 68 & E-115 & $219 / 318$ \\
\hline MCOR0088C & 463 & 2 & $\mathrm{FF}$ & CT & ubiquitin-like/S30 ribosomal fusion protein & $x$ & >ref|NP_999102.1| & 81 & $2.00 \mathrm{E}-56$ & $109 / 133$ \\
\hline MCOR0089C & 874 & 19 & FF & CT & $60 S$ ribosomal protein $\mathrm{L} 7 \mathrm{a}$ & $\mathrm{x}$ & sp|P32429|RL7A_CHICK & 96 & $E-146$ & $258 / 266$ \\
\hline MCOR0090C & 735 & 27 & FF & TL & C-type lectin-like protein 2 & $\mathrm{x}$ & $>g b|A A K 43585.1|$ & 74 & 2.00E-72 & $117 / 158$ \\
\hline MCOR0091C & 427 & 2 & FF & TNtx & Alpha-neurotoxin homolog 7 precursor & $\mathrm{x}$ & sp|Q9PRI1|NXAH7_MICCO & 97 & $2.00 \mathrm{E}-38$ & $74 / 76$ \\
\hline MCOR0092C & 485 & 18 & $\mathrm{FF}$ & TNtx & alpha neurotoxin & $x$ & $>g b|A A F 75223.1|$ & 49 & $3.00 \mathrm{E}-15$ & $39 / 79$ \\
\hline MCOR0093C & 603 & 2 & $\mathrm{FF}$ & TP & phospholipase A2 & $x$ & $>g b \mid$ AAN60018.1| & 90 & 5.00E-73 & $134 / 148$ \\
\hline MCOR0094C & 512 & 12 & $\mathrm{FF}$ & TNtx & weak toxin 3 / cardiotoxin 6 & $x$ & gb|AAL30061.1| & 49 & $3.00 \mathrm{E}-17$ & $43 / 87$ \\
\hline
\end{tabular}




\begin{tabular}{|c|c|c|c|c|c|c|c|c|c|c|}
\hline CLUSTER & Tamanho (pb) & $\begin{array}{c}N^{\circ} \text { de Clones } \\
\text { no Cluster }\end{array}$ & FULL & $\begin{array}{c}\text { Categoria } \\
\text { 1aria } \\
\end{array}$ & PRODUTO & Blast & Accession $\mathrm{N}^{\circ}$ & $\%$ ID & e-value & overlap \\
\hline MCOR0095C & 719 & 11 & FF & TL & C-type lectin-like protein 2 & $x$ & $>$ gb|AAK43585.1 & 74 & $7.00 \mathrm{E}-71$ & $116 / 155$ \\
\hline MCOR0096C & 534 & 3 & FP & $\mathrm{CR}$ & Peptidyl-prolyl cis-trans isomerase & $x$ & sp|P24367|PPIB_CHICK & 84 & $1.00 \mathrm{E}-77$ & $141 / 166$ \\
\hline MCOR0097C & 531 & 5 & $\mathrm{FF}$ & CT & ribosomal protein S11 & $x$ & >ref|NP_001026004.1| & 97 & $1.00 \mathrm{E}-84$ & $153 / 157$ \\
\hline MCOR0098C & 679 & 6 & $P$ & CT & similar to ubiquitin A-52 & $x$ & >ref|XP_533870.2| & 99 & $3.00 \mathrm{E}-69$ & $129 / 130$ \\
\hline MCOR0099C & 553 & 2 & FF & $\mathrm{CR}$ & Calpactin I light chain & $x$ & $>$ ref|XP_533060.2| & 62 & $1.00 \mathrm{E}-38$ & $76 / 121$ \\
\hline MCOR0100C & 488 & 27 & $\mathrm{FF}$ & $\mathrm{TNtx}$ & muscarinic toxin precursor & $x$ & $>\mathrm{gb}|\mathrm{ABB} 83639.1|$ & 51 & $1.00 \mathrm{E}-15$ & $44 / 85$ \\
\hline MCOR0101C & 495 & 2 & $P$ & CT & similar to ribosomal protein L13a & $x$ & ref|XP_512821.1| & 92 & $2.00 \mathrm{E}-84$ & $153 / 165$ \\
\hline MCOR0102C & 556 & 2 & FP & CT & $60 S$ ribosomal protein L15 & $x$ & sp|P61313|RL15_HUMAN & 100 & $E-100$ & $175 / 175$ \\
\hline MCOR0103C & 445 & 2 & $\mathrm{FF}$ & TNtx & long chain neurotoxin LsIII & $x$ & $>$ dbj|BAC78204.1| & 55 & $1.00 \mathrm{E}-19$ & $48 / 86$ \\
\hline MCOR0104C & 483 & 2 & $\mathrm{FF}$ & CT & $40 S$ ribosomal protein $\mathrm{S} 12$ & $x$ & sp|P84175|RS12_CHICK & 98 & $1.00 \mathrm{E}-70$ & $130 / 132$ \\
\hline MCOR0105C & 471 & 5 & $\mathrm{FF}$ & TNtx & Cardiotoxin $4 \mathrm{~N}$ precursor (CTX-4N) & $\mathrm{x}$ & sp|Q9W6W9|CTX4N_NAJAT & 56 & $4.00 \mathrm{E}-15$ & $46 / 82$ \\
\hline MCOR0106C & 438 & 6 & $\mathrm{FF}$ & TNtx & Alpha-neurotoxin homolog 7 precursor & $x$ & sp|Q9PRI1|NXAH7_MICCO & 100 & 4.00E-41 & $78 / 78$ \\
\hline MCOR0107C & 506 & 2 & $P$ & CT & similar to ribosomal protein $\mathrm{S} 23$ & $x$ & $>$ ref $\left|X P \_424903.1\right|$ & 97 & $2.00 \mathrm{E}-77$ & $143 / 146$ \\
\hline MCOR0108C & 606 & 6 & $\mathrm{FF}$ & CT & 60S ribosomal protein L41 (HG12) & $x$ & sp|P62945|RL41_HUMAN & 100 & 4.00E-06 & $25 / 25$ \\
\hline MCOR0109C & 474 & 12 & $\mathrm{FF}$ & TNtx & Cytotoxin 7 precursor (Cardiotoxin 7) & $x$ & sp|P49122|CX7_NAJAT & 51 & $5.00 \mathrm{E}-16$ & $42 / 82$ \\
\hline MCOR0110C & 410 & 2 & $\mathrm{FF}$ & TK & trypsin inhibitor preproprotein & $x$ & $>g b|A A P 04484.1|$ & 59 & $2.00 \mathrm{E}-25$ & $53 / 89$ \\
\hline MCOR0111C & 537 & 2 & $P$ & CT & similar to $40 \mathrm{~S}$ ribosomal protein & $x$ & $>$ ref|XP_536549.2| & 95 & $2.00 \mathrm{E}-65$ & $125 / 131$ \\
\hline MCOR0112C & 499 & 2 & $P$ & CT & similar to ribosomal protein & $x$ & $>$ ref|XP_424903.1| & 96 & $5.00 \mathrm{E}-78$ & $144 / 149$ \\
\hline MCOR0113C & 453 & 2 & $\mathrm{FF}$ & CT & similar to $40 \mathrm{~S}$ ribosomal protein & $x$ & sp|P62273|RS29_HUMAN & 100 & $1.00 \mathrm{E}-28$ & $56 / 56$ \\
\hline MCOR0114C & 459 & 2 & $\mathrm{FF}$ & CT & ribosomal protein L28 & $\mathrm{x}$ & >ref|NP_001016714.1| & 88 & $2.00 \mathrm{E}-65$ & $121 / 137$ \\
\hline MCOR0115C & 596 & 3 & $\mathrm{FF}$ & CT & 40S ribosomal protein & $x$ & sp|P62277|RS13_HUMAN & 100 & $2.00 \mathrm{E}-80$ & $151 / 151$ \\
\hline MCOR0116C & 497 & 2 & $\mathrm{FF}$ & CT & $40 S$ ribosomal protein $\mathrm{S} 15$ & $x$ & sp|P62841|RS15_HUMAN & 100 & $3.00 \mathrm{E}-78$ & $145 / 145$ \\
\hline MCOR0117C & 415 & 2 & $\mathrm{FF}$ & TNtx & Alpha-neurotoxin homolog 7 & $x$ & sp|Q9PRI1|NXAH7_MICCO & 89 & $1.00 \mathrm{E}-36$ & $70 / 78$ \\
\hline MCOR0118C & 495 & 33 & $\mathrm{FF}$ & TNtx & Alpha-neurotoxin homolog 8 & $x$ & sp|P58370|NXAH8_MICCO & 98 & $4.00 \mathrm{E}-47$ & $85 / 86$ \\
\hline
\end{tabular}




\begin{tabular}{|c|c|c|c|c|c|c|c|c|c|c|}
\hline CLUSTER & Tamanho (pb) & $\begin{array}{c}N^{\circ} \text { de Clones } \\
\text { no Cluster }\end{array}$ & FULL & $\begin{array}{l}\text { Categoria } \\
\text { 1aria }\end{array}$ & PRODUTO & Blast & Accession $\mathrm{N}^{\circ}$ & $\%$ ID & e-value & overlap \\
\hline MCOR0119C & 473 & 3 & $P$ & CT & elongation factor 2 & $x$ & $>g b|A A Y 33974.1|$ & 97 & $1.00 \mathrm{E}-71$ & $129 / 132$ \\
\hline MCOR0120C & 476 & 4 & $\mathrm{FF}$ & $\mathrm{TNtx}$ & muscarinic toxin precursor & $x$ & $>g b|A B B 83638.1|$ & 63 & $1.00 \mathrm{E}-24$ & $55 / 86$ \\
\hline MCOR0121S & 343 & 1 & $P$ & $\mathrm{CM}$ & Glycogen phosphorylase, muscle form & $\mathrm{x}$ & sp|Q9WUB3|PYGM_MOUSE & 87 & $1.00 \mathrm{E}-53$ & $100 / 114$ \\
\hline MCOR0122S & 429 & 1 & $P$ & UF & similar to Pim1 protein & $x$ & >ref|XP_690996.1| & 41 & 3.00E-19 & $54 / 131$ \\
\hline MCOR0123S & 444 & 1 & & $\mathrm{NH}$ & no hit & & & & & \\
\hline MCOR0124S & 465 & 1 & $\mathrm{FP}$ & CT & eukaryotic translation initiation factor & $x$ & >dbj|BAD92756.1| & 83 & $6.00 \mathrm{E}-70$ & $126 / 151$ \\
\hline MCOR0125S & 231 & 1 & $\mathrm{FP}$ & CE & NEDD4 family-interacting protein & $\mathrm{x}$ & sp|Q6GLN5|NFIP1_XENLA & 67 & $5.00 \mathrm{E}-07$ & $27 / 40$ \\
\hline MCOR0126S & 333 & 1 & & $\mathrm{NH}$ & no hit & & & & & \\
\hline MCOR0127S & 182 & 1 & $\mathrm{FP}$ & MT & similar to ATPase inhibitor & $\mathrm{x}$ & >ref|XP_691054.1| & 82 & $1.00 \mathrm{E}-09$ & $28 / 34$ \\
\hline MCOR0128S & 507 & 1 & $\mathrm{FF}$ & CT & $40 S$ ribosomal protein $\mathrm{S} 18$ & $x$ & sp|P62269|RS18_HUMAN & 100 & 4.00E-82 & $152 / 152$ \\
\hline MCOR0129S & 413 & 1 & $P$ & CT & eukaryotic translation elongation factor & $\mathrm{x}$ & >ref|NP_001027570.1| & 99 & $6.00 \mathrm{E}-51$ & $100 / 101$ \\
\hline MCOR0130S & 340 & 1 & & $\mathrm{NH}$ & no hit & & & & & \\
\hline MCOR0131S & 413 & 1 & $P$ & CT & elongation factor- 1 alpha & $\mathrm{x}$ & $>$ dbj|BAD74118.1| & 98 & 2.00E-72 & $135 / 137$ \\
\hline MCOR0132S & 418 & 1 & & $\mathrm{NH}$ & no hit & & & & & \\
\hline MCOR0133S & 515 & 1 & $P$ & CT & similar to 605 ribosomal protein & $\mathrm{x}$ & >ref|NP_001006241.1| & 93 & $5.00 \mathrm{E}-93$ & $160 / 171$ \\
\hline MCOR0134S & 460 & 1 & $P$ & $\mathrm{CP}$ & Valosin-containing protein & $x$ & $>\mathrm{gb}|\mathrm{AAH} 07562.2|$ & 99 & $8.00 \mathrm{E}-80$ & $151 / 152$ \\
\hline MCOR0135S & 382 & 1 & $P$ & CT & Transcription elongation factor $\mathrm{A}$ & $\mathrm{x}$ & sp|O75764|TCEA3_HUMAN & 65 & $4.00 \mathrm{E}-30$ & $57 / 87$ \\
\hline MCOR0136S & 480 & 1 & $\mathrm{P}$ & $C D$ & autocrine motility factor receptor & $x$ & sp|Q9UKV5|AMFR2_HUMAN & 85 & $1.00 \mathrm{E}-76$ & $136 / 160$ \\
\hline MCOR0137S & 525 & 1 & $P$ & OF & Coatomer subunit alpha & $\mathrm{x}$ & $>\mathrm{gb}|\mathrm{AAH} 75251.1|$ & 90 & $5.00 \mathrm{E}-34$ & $65 / 72$ \\
\hline MCOR0138S & 492 & 1 & $P$ & $C D$ & Ubiquitin-activating enzyme & $\mathrm{x}$ & >sp|P31253|UBE1X_MOUSE & 41 & 4.00E-28 & $62 / 150$ \\
\hline MCOR0139S & 417 & 1 & $P$ & $C D$ & procollagen (type III) N-endopeptidase & $\mathrm{x}$ & >ref|NP_001020611.1| & 90 & $9.00 \mathrm{E}-36$ & $79 / 87$ \\
\hline MCOR0140S & 503 & 1 & $P$ & $\mathrm{CP}$ & Stress-induced-phosphoprotein 1 & $\mathrm{x}$ & sp|Q60864|STIP1_MOUSE & 90 & $7.00 \mathrm{E}-83$ & $145 / 161$ \\
\hline MCOR0141S & 501 & 1 & $P$ & UF & hypothetical protein XP_418405 & $x$ & $>$ ref $\left|X P \_418405.1\right|$ & 81 & $6.00 \mathrm{E}-67$ & $117 / 144$ \\
\hline MCOR0142S & 445 & 1 & $P$ & DT & Bungarus flaviceps beta-bgt a2 & $\mathrm{N}$ & $>d b j|A B 112356.1|$ & 94 & $2.00 \mathrm{E}-15$ & $55 / 58$ \\
\hline
\end{tabular}




\begin{tabular}{|c|c|c|c|c|c|c|c|c|c|c|}
\hline CLUSTER & Tamanho (pb) & $\begin{array}{c}N^{\circ} \text { de Clones } \\
\text { no Cluster }\end{array}$ & FULL & $\begin{array}{c}\text { Categoria } \\
\text { 1aria }\end{array}$ & PRODUTO & Blast & Accession $\mathrm{N}^{\circ}$ & $\%$ ID & e-value & overlap \\
\hline MCOR0143S & 533 & 1 & FF & CE & myosin alkali light chain & $x$ & $>g b|A A A 48979.1|$ & 97 & $2.00 \mathrm{E}-81$ & $147 / 151$ \\
\hline MCOR0144S & 473 & 1 & & $\mathrm{NH}$ & no hit & & & & & \\
\hline MCOR0145S & 511 & 1 & $\mathrm{FP}$ & CT & Eukaryotic translation initiation factor & $\mathrm{x}$ & sp|Q9DBZ5|IF3C_MOUSE & 89 & 4.00E-81 & $146 / 163$ \\
\hline MCOR0146S & 424 & 1 & $P$ & UF & similar to $9530046 \mathrm{H} 09 \mathrm{Rik}$ protein & $x$ & $>$ ref|XP_418182.1| & 86 & $2.00 \mathrm{E}-36$ & $74 / 86$ \\
\hline MCOR0147S & 532 & 1 & $P$ & $\mathrm{CP}$ & xylosylprotein & $x$ & >ref|NP_001035000.1| & 77 & $4.00 \mathrm{E}-65$ & $119 / 153$ \\
\hline MCOR0148S & 492 & 1 & & $\mathrm{NH}$ & no hit & & & & & \\
\hline MCOR0149S & 541 & 1 & $P$ & $\mathrm{TN}$ & Venom nerve growth factor 1 & $\mathrm{x}$ & sp|Q3HXY0|NGFV1_HOPST & 93 & $6.00 \mathrm{E}-89$ & $160 / 172$ \\
\hline MCOR0150S & 456 & 1 & $P$ & UF & Hypothetical protein MGC76288 & $\mathrm{x}$ & $>\mathrm{gb}|\mathrm{AAH} 61625.1|$ & 60 & $3.00 \mathrm{E}-41$ & $89 / 146$ \\
\hline MCOR0151S & 501 & 1 & FP & OF & CD2 antigen cytoplasmic tail-binding & $x$ & sp|O95400|CD2B2_HUMAN & 71 & $4.00 \mathrm{E}-54$ & $100 / 140$ \\
\hline MCOR0152S & 498 & 1 & $P$ & $\mathrm{TNtx}$ & Alpha-neurotoxin homolog 8 precursor & $x$ & sp|P58370|NXAH8_MICCO & 95 & $2.00 \mathrm{E}-39$ & $71 / 74$ \\
\hline MCOR0153S & 484 & 1 & & $\mathrm{NH}$ & no hit & & & & & \\
\hline MCOR0154S & 360 & 1 & & $\mathrm{NH}$ & no hit & & & & & \\
\hline MCOR0155S & 418 & 1 & $P$ & OF & MHC class I protein & $x$ & $>g b|A A A 48519.1|$ & 50 & $1.00 \mathrm{E}-26$ & $55 / 108$ \\
\hline MCOR0156S & 486 & 1 & $P$ & $\mathrm{CM}$ & glucose-6-phosphate dehydrogenase & $x$ & >sp|O55044|G6PD_CRIGR & 77 & 2.00E-73 & $125 / 161$ \\
\hline MCOR0157S & 428 & 1 & $\mathrm{FP}$ & OF & MHC class I protein & $\mathrm{x}$ & $>g b|A A A 49389.1|$ & 76 & $2.00 \mathrm{E}-53$ & $96 / 126$ \\
\hline MCOR0158S & 462 & 1 & FF & $\mathrm{CP}$ & Signal recognition particle $19 \mathrm{kDa}$ protein & $\mathrm{x}$ & sp|Q5RBR1|SRP19_PONPY & 80 & $9.00 \mathrm{E}-62$ & $113 / 140$ \\
\hline MCOR0159S & 508 & 1 & $P$ & UF & Protein C20orf116 precursor & $x$ & sp|Q96HY6|CT116_HUMAN & 75 & $2.00 \mathrm{E}-64$ & $123 / 164$ \\
\hline MCOR0160S & 452 & 1 & $P$ & TS & Prostasin precursor & $x$ & sp|Q9ES87|PRSS8_RAT & 53 & 4.00E-42 & $79 / 148$ \\
\hline MCOR0161S & 382 & 1 & $P$ & UF & similar to NG37 protein & $x$ & >ref|XP_849170.1| & 32 & $1.00 \mathrm{E}-10$ & $40 / 125$ \\
\hline MCOR0162S & 475 & 1 & & $\mathrm{NH}$ & no hit & & & & & \\
\hline MCOR0163S & 398 & 1 & $P$ & $\mathrm{CR}$ & Intestinal alkaline phosphatase & $x$ & $>g b|A A F 36717.1|$ & 68 & $9.00 \mathrm{E}-39$ & $82 / 120$ \\
\hline MCOR0164S & 332 & 1 & & $\mathrm{CM}$ & malate dehydrogenase $2, N A D$ & & & & & \\
\hline MCOR0165S & 377 & 1 & $P$ & $\mathrm{CP}$ & similar to SEC14-like protein 1 & $x$ & $>$ ref $\left|X P \_415614.1\right|$ & 94 & $1.00 \mathrm{E}-65$ & $118 / 125$ \\
\hline MCOR0166S & 443 & 1 & $P$ & UF & hypothetical protein XP_845157 & $x$ & >ref|XP_850250.1| & 68 & $3.00 \mathrm{E}-51$ & $96 / 141$ \\
\hline
\end{tabular}




\begin{tabular}{|c|c|c|c|c|c|c|c|c|c|c|}
\hline CLUSTER & Tamanho (pb) & $\begin{array}{c}N^{\circ} \text { de Clones } \\
\text { no Cluster }\end{array}$ & FULL & $\begin{array}{c}\text { Categoria } \\
\text { 1aria }\end{array}$ & PRODUTO & Blast & Accession $\mathrm{N}^{\circ}$ & $\%$ ID & e-value & overlap \\
\hline MCOR0167S & 429 & 1 & $P$ & OF & integral membrane glycoprotein & $x$ & $>$ >gb|AAA30859.1| & 45 & $2.00 \mathrm{E}-32$ & $63 / 139$ \\
\hline MCOR0168S & 342 & 1 & $P$ & CE & similar to myosin, heavy polypeptide 7 & $x$ & $>$ ref|XP_546980.2| & 81 & 8.00E-46 & $91 / 112$ \\
\hline MCOR0169S & 164 & 1 & $P$ & OF & MHC class I protein & $\mathrm{x}$ & $>$ gb|AAA49389.1| & 78 & $5.00 \mathrm{E}-18$ & $40 / 51$ \\
\hline MCOR0170S & 446 & 1 & $P$ & $\mathrm{CM}$ & similar to Probable cation-transporting & $x$ & $>$ ref $\left|X P \_423767.1\right|$ & 80 & $1.00 \mathrm{E}-58$ & $115 / 142$ \\
\hline MCOR0171S & 424 & 1 & $P$ & $\mathrm{CP}$ & similar to alpha-1,3-mannosyltransferase & $x$ & $>$ ref $\left|X P \_859208.1\right|$ & 75 & $4.00 \mathrm{E}-33$ & $63 / 83$ \\
\hline MCOR0172S & 473 & 1 & $P$ & RT & predicted CDS, reverse transcriptase & $x$ & $>$ ref $\left|X P \_780819.1\right|$ & 47 & 2.00E-34 & $72 / 153$ \\
\hline MCOR0173S & 402 & 1 & $P$ & CT & heterogeneous nuclear ribonucleoprotein $\mathrm{A} 3$ & $\mathrm{X}$ & >ref|NP_001026424.1| & 78 & $3.00 \mathrm{E}-58$ & $105 / 133$ \\
\hline MCOR0174S & 403 & 1 & $P$ & UF & similar to OCIA domain containing 1 & $x$ & $>$ ref|XP_707712.1| & 51 & 2.00E-24 & $59 / 115$ \\
\hline MCOR0175S & 370 & 1 & $P$ & CT & ribosomal protein S3 & $\mathrm{x}$ & gb|AAQ94564.1| & 96 & $1.00 \mathrm{E}-19$ & $50 / 52$ \\
\hline MCOR0176S & 393 & 1 & $P$ & $\mathrm{TNtx}$ & Weak neurotoxin 10 precursor & $x$ & sp|Q802B2|TW10_NAJSP & 41 & 4.00E-09 & $26 / 63$ \\
\hline MCOR0177S & 449 & 1 & $P$ & $\mathrm{CR}$ & similar to $\mathrm{SH} 3$ domain protein & $\mathrm{x}$ & $>$ ref|XP_534577.2| & 66 & 2.00E-55 & $105 / 158$ \\
\hline MCOR0178S & 471 & 1 & & $\mathrm{NH}$ & no hit & & & & & \\
\hline MCOR0179S & 359 & 1 & $P$ & UF & similar to hypothetical protein FLJ22662 & $x$ & $>$ ref $\left|X P \_416206.1\right|$ & 59 & $6.00 \mathrm{E}-37$ & $71 / 119$ \\
\hline MCOR0180S & 377 & 1 & $P$ & $\mathrm{CM}$ & fructose-1,6-bisphosphate aldolase A & $x$ & $>$ gb|AAA37210.2| & 88 & 8.00E-59 & $111 / 125$ \\
\hline MCOR0181S & 456 & 1 & FF & $\mathrm{CR}$ & Fatty acid-binding protein, heart & $\mathrm{x}$ & sp|P10790|FABPH_BOVIN & 75 & 2.00E-52 & $98 / 129$ \\
\hline MCOR0182S & 383 & 1 & $P$ & OF & MHC class I protein & $x$ & $>g b|A A A 49389.1|$ & 74 & $3.00 \mathrm{E}-43$ & $77 / 104$ \\
\hline MCOR0183S & 425 & 1 & $P$ & $\mathrm{CR}$ & StAR-related lipid transfer protein 7 & $\mathrm{x}$ & sp|Q8R1R3|STAR7_MOUSE & 91 & $9.00 \mathrm{E}-71$ & $125 / 136$ \\
\hline MCOR0184S & 392 & 1 & $P$ & $\mathrm{CP}$ & Protein transport protein Sec61 & $x$ & sp|P38377|S61A1_CANFA & 97 & $6.00 \mathrm{E}-64$ & $123 / 126$ \\
\hline MCOR0185S & 426 & 1 & $P$ & OF & MHC class I protein & $x$ & $>g b|A A A 48518.1|$ & 58 & $2.00 \mathrm{E}-43$ & $79 / 135$ \\
\hline MCOR0186S & 494 & 1 & $P$ & CE & similar to Tubulin alpha- 6 chain & $x$ & $>$ ref $\left|X P \_862226.1\right|$ & 98 & $2.00 \mathrm{E}-83$ & $150 / 153$ \\
\hline MCOR0187S & 600 & 1 & $P$ & UF & hypothetical protein LOC394935 & $x$ & ref|NP_989311.1| & 56 & $2.00 \mathrm{E}-50$ & $104 / 184$ \\
\hline MCOR0188S & 205 & 1 & $P$ & $\mathrm{CM}$ & Ca2+-transporting ATPase & $x$ & $>\mathrm{gb}|\mathrm{AAY} 67989.1|$ & 95 & $1.00 \mathrm{E}-30$ & $65 / 68$ \\
\hline MCOR0189S & 459 & 1 & FP & CE & actin related protein $2 / 3$ & $x$ & >ref|NP_001025803.1| & 85 & 8.00E-64 & $108 / 126$ \\
\hline MCOR0190S & 457 & 1 & $P$ & MT & Cytochrome $\mathrm{c}$ oxidase subunit 1 & $x$ & sp|O79548|COX1_DINSE & 83 & $2.00 \mathrm{E}-40$ & $89 / 106$ \\
\hline
\end{tabular}




\begin{tabular}{|c|c|c|c|c|c|c|c|c|c|c|}
\hline CLUSTER & Tamanho $(\mathrm{pb})$ & $\begin{array}{c}N^{\circ} \text { de Clones } \\
\text { no Cluster }\end{array}$ & FULL & $\begin{array}{c}\text { Categoria } \\
\text { 1aria }\end{array}$ & PRODUTO & Blast & Accession $\mathrm{N}^{\circ}$ & $\%$ ID & e-value & overlap \\
\hline MCOR0191S & 299 & 1 & $P$ & CT & elongation factor 2 & $x$ & >gb|AAY33974.1| & 98 & $3.00 \mathrm{E}-43$ & $85 / 86$ \\
\hline MCOR0192S & 556 & 1 & & $\mathrm{NH}$ & no hit & & & & & \\
\hline MCOR0193S & 391 & 1 & $\mathrm{FP}$ & TB & natriuretic peptide & $x$ & $>\mathrm{gb}|\mathrm{AAC} 60341.1|$ & 88 & $1.00 \mathrm{E}-20$ & $52 / 59$ \\
\hline MCOR0194S & 493 & 1 & $P$ & $\mathrm{CR}$ & bromodomain and PHD finger & $x$ & >ref|NP_001026635.1| & 95 & $5.00 \mathrm{E}-39$ & $78 / 82$ \\
\hline MCOR0195S & 464 & 1 & FP & TB & natriuretic peptide & $x$ & $>\mathrm{gb}|\mathrm{AAC} 60341.1|$ & 86 & $1.00 \mathrm{E}-24$ & $57 / 66$ \\
\hline MCOR0196S & 493 & 1 & $\mathrm{FF}$ & OF & galectin-1 & $x$ & gb|AAT37622.1| & 51 & $1.00 \mathrm{E}-32$ & $68 / 132$ \\
\hline MCOR0197S & 287 & 1 & $P$ & CT & eukaryotic translation inititation & $x$ & $>g b|A A L 54908.1|$ & 98 & $4.00 \mathrm{E}-48$ & $94 / 95$ \\
\hline MCOR0198S & 472 & 1 & $\mathrm{FP}$ & $\mathrm{CP}$ & Translocation-associated membrane & $x$ & >ref|NP_989731.1| & 85 & $5.00 \mathrm{E}-51$ & $96 / 112$ \\
\hline MCOR0199S & 437 & 1 & $P$ & CT & Thyroid hormone receptor-associated & $\mathrm{x}$ & $>$ ref $\left|X P_{-} 417769.1\right|$ & 80 & $2.00 \mathrm{E}-58$ & $108 / 134$ \\
\hline MCOR0200S & 546 & 1 & $P$ & TA & L-amino acid oxidase precursor & $x$ & $>g b|A A Y 89682.1|$ & 75 & $5.00 \mathrm{E}-20$ & $47 / 62$ \\
\hline MCOR0201S & 435 & 1 & $P$ & $\mathrm{CM}$ & nicotinamide $\mathrm{N}$-methyltransferase & $x$ & sp|P40261|NNMT_HUMAN & 61 & $9.00 \mathrm{E}-44$ & $81 / 131$ \\
\hline MCOR0202S & 224 & 1 & & $\mathrm{NH}$ & no hit & & & & & \\
\hline MCOR0203S & 474 & 1 & $\mathrm{FP}$ & TL & C-type lectin-like protein 2 & $\mathrm{x}$ & $>$ gb|AAK43585.1| & 77 & $6.00 \mathrm{E}-38$ & $68 / 88$ \\
\hline MCOR0204S & 290 & 1 & $P$ & CE & putative collagen alpha-2 $(\mathrm{XI})$ chain & $x$ & $>g b|A A A 67751.1|$ & 54 & $6.00 \mathrm{E}-16$ & $42 / 77$ \\
\hline MCOR0205S & 426 & 1 & & $\mathrm{NH}$ & no hit & & & & & \\
\hline MCOR0206S & 559 & 1 & & $\mathrm{NH}$ & no hit & & & & & \\
\hline MCOR0207S & 490 & 1 & FP & CT & Protein FAM50A (XAP-5 protein) & $x$ & $>$ ref $\left|X P \_215220.3\right|$ & 88 & $1.00 \mathrm{E}-60$ & $121 / 136$ \\
\hline MCOR0208S & 189 & 1 & $P$ & CR & serine/threonine kinase 19 & $x$ & >emb|CAI41867.1| & 58 & $7.00 \mathrm{E}-10$ & $29 / 50$ \\
\hline MCOR0209S & 528 & 1 & & $\mathrm{NH}$ & no hit & & & & & \\
\hline MCOR0210S & 565 & 1 & & $\mathrm{NH}$ & no hit & & & & & \\
\hline MCOR0211S & 579 & 1 & $P$ & $\mathrm{CM}$ & NADPH dependent diflavin oxidoreductase 1 & $\mathrm{x}$ & $>$ ref $\left|X P_{-} 415553.1\right|$ & 81 & $1.00 \mathrm{E}-74$ & $129 / 158$ \\
\hline MCOR0212S & 522 & 1 & $P$ & CT & splicing factor 3B subunit 2 & $x$ & $>\mathrm{gb}|\mathrm{AAH} 14125.2|$ & 97 & $\mathrm{E}-101$ & $170 / 174$ \\
\hline MCOR0213S & 374 & 1 & & $\mathrm{NH}$ & no hit & & & & & \\
\hline MCOR0214S & 560 & 1 & $P$ & CT & similar to initiation factor elF-2Be & $x$ & >ref|XP_422755.1| & 68 & $5.00 \mathrm{E}-68$ & $126 / 183$ \\
\hline
\end{tabular}




\begin{tabular}{|c|c|c|c|c|c|c|c|c|c|c|}
\hline CLUSTER & Tamanho (pb) & $\begin{array}{c}N^{\circ} \text { de Clones } \\
\text { no Cluster }\end{array}$ & FULL & $\begin{array}{l}\text { Categoria } \\
\text { 1aria }\end{array}$ & PRODUTO & Blast & Accession $\mathrm{N}^{\circ}$ & $\%$ ID & e-value & overlap \\
\hline MCOR0215S & 552 & 1 & $\mathrm{FP}$ & $\mathrm{CM}$ & ATP synthase, $\mathrm{H}+$ transporting & $\mathrm{x}$ & ref|NP_001011021.1| & 72 & 4.00E-51 & $97 / 155$ \\
\hline MCOR0216S & 570 & 1 & $P$ & $\mathrm{CM}$ & Dolichyl-diphosphooligosaccharide & $x$ & >sp|P48440|OST48_CHICK & 93 & $2.00 \mathrm{E}-98$ & $177 / 190$ \\
\hline MCOR0217S & 559 & 1 & $P$ & UF & LOC383103 protein & $\mathrm{x}$ & >ref|NP_001013800.1| & 81 & $6.00 \mathrm{E}-75$ & $132 / 162$ \\
\hline MCOR0218S & 572 & 1 & $\mathrm{FP}$ & $C D$ & Cysteine protease ATG4A & $\mathrm{x}$ & sp|Q5ZIW7|ATG4A_CHICK & 83 & 4.00E-93 & $156 / 187$ \\
\hline MCOR0219S & 609 & 1 & $P$ & UF & $\mathrm{N}$-myc downstream-regulated gene 2 & $\mathrm{x}$ & ref|NP_001030381.1| & 87 & $5.00 \mathrm{E}-58$ & $114 / 131$ \\
\hline MCOR0220S & 272 & 1 & $P$ & UF & similar to KIAA0265 protein & $x$ & $>$ ref $\left|X P \_425257.1\right|$ & 67 & $7.00 \mathrm{E}-10$ & $29 / 43$ \\
\hline MCOR0221S & 577 & 1 & $P$ & UF & similar to RIKEN cDNA $4921536 I 21$ & $\mathrm{x}$ & $>$ ref $\left|X P \_422374.1\right|$ & 63 & $5.00 \mathrm{E}-10$ & $33 / 52$ \\
\hline MCOR0222S & 527 & 1 & $\mathrm{FP}$ & UF & similar to COMM domain containing 7 & $x$ & >ref $\left|X P \_852352.1\right|$ & 77 & $1.00 \mathrm{E}-65$ & $127 / 164$ \\
\hline MCOR0223S & 515 & 1 & & $\mathrm{NH}$ & no hit & & & & & \\
\hline MCOR0224S & 551 & 1 & $P$ & CE & tropomyosin & $x$ & $>g b|A A A 49112.1|$ & 94 & $2.00 \mathrm{E}-88$ & $173 / 183$ \\
\hline MCOR0225S & 509 & 1 & $P$ & $\mathrm{CR}$ & similar to programmed cell death & $\mathrm{x}$ & ref|NP_001006815.1| & 84 & $5.00 \mathrm{E}-39$ & $80 / 95$ \\
\hline MCOR0226S & 532 & 1 & FF & OF & Lymphocyte antigen Ly-6E precursor & $\mathrm{x}$ & sp|Q90986|LY6E_CHICK & 56 & $8.00 \mathrm{E}-36$ & $70 / 125$ \\
\hline MCOR0227S & 535 & 1 & FP & $\mathrm{CR}$ & similar to death-associated protein 3 & $x$ & $>$ ref $\left|X P \_514436.1\right|$ & 40 & $7.00 \mathrm{E}-11$ & $35 / 86$ \\
\hline MCOR0228S & 558 & 1 & $P$ & $\mathrm{CM}$ & NAD kinase & $x$ & ref|NP_001026041.1| & 91 & $1.00 \mathrm{E}-90$ & $169 / 185$ \\
\hline MCOR0229S & 557 & 1 & $P$ & RT & predicted CDS, reverse transcriptase & $\mathrm{x}$ & $>$ ref $\left|X P \_780819.1\right|$ & 45 & $2.00 \mathrm{E}-21$ & $45 / 98$ \\
\hline MCOR0230S & 458 & 1 & $P$ & $\mathrm{CM}$ & Succinate dehydrogenase [ubiquinone] & $x$ & sp|Q9CQA3|DHSB_MOUSE & 88 & $1.00 \mathrm{E}-77$ & $130 / 147$ \\
\hline MCOR0231S & 500 & 1 & $P$ & $C D$ & similar to Xaa-Pro aminopeptidase 2 & $\mathrm{x}$ & >ref|XP_580998.2| & 60 & $2.00 \mathrm{E}-50$ & $97 / 160$ \\
\hline MCOR0232S & 545 & 1 & $\mathrm{P}$ & $C D$ & Calpain small subunit 1 & $x$ & sp|P04574|CPNS1_PIG & 67 & $4.00 \mathrm{E}-64$ & $122 / 180$ \\
\hline MCOR0233S & 490 & 1 & FP & $\mathrm{CP}$ & Signal peptidase complex subunit 3 & $\mathrm{x}$ & sp|P28687|SPCS3_CHICK & 91 & $1.00 \mathrm{E}-51$ & $102 / 111$ \\
\hline MCOR0234S & 548 & 1 & $P$ & MT & NADH dehydrogenase subunit 5 & $x$ & >ref|YP_313678.1| & 68 & $3.00 \mathrm{E}-61$ & $127 / 186$ \\
\hline MCOR0235S & 486 & 1 & $P$ & $C D$ & Ubiquinol-cytochrome $\mathrm{c}$ reductase core & $\mathrm{x}$ & gb|AAI06253.1| & 64 & $1.00 \mathrm{E}-53$ & $105 / 162$ \\
\hline MCOR0236S & 493 & 1 & FP & CE & similar to microtubule-associated protein & $\mathrm{x}$ & ref $\left|X P \_592416.2\right|$ & 96 & $1.00 \mathrm{E}-57$ & $109 / 113$ \\
\hline MCOR0237S & 559 & 1 & & $\mathrm{NH}$ & no hit & & & & & \\
\hline MCOR0238S & 412 & 1 & $P$ & DT & Ohanin precursor, gene, complete cds & $\mathrm{N}$ & $>g b|D Q 103590.1|$ & 87 & $1.00 \mathrm{E}-06$ & $55 / 63$ \\
\hline
\end{tabular}




\begin{tabular}{|c|c|c|c|c|c|c|c|c|c|c|}
\hline CLUSTER & Tamanho (pb) & $\begin{array}{c}N^{\circ} \text { de Clones } \\
\text { no Cluster }\end{array}$ & FULL & $\begin{array}{c}\text { Categoria } \\
\text { 1aria } \\
\end{array}$ & PRODUTO & Blast & Accession $\mathrm{N}^{\circ}$ & $\%$ ID & e-value & overlap \\
\hline MCOR0239S & 527 & 1 & $\mathrm{FP}$ & OF & Ferritin, higher subunit (Ferritin $\mathrm{H}$ ) & $\mathrm{x}$ & >sp|P07229|FRI1_RANCA & 75 & $1.00 \mathrm{E}-47$ & $88 / 116$ \\
\hline MCOR0240S & 554 & 1 & $P$ & OF & optic atrophy 1 (autosomal dominant) & $x$ & ref|NP_001034398.1| & 91 & $7.00 \mathrm{E}-99$ & $168 / 184$ \\
\hline MCOR0241S & 545 & 1 & $P$ & $\mathrm{CM}$ & glucose regulated thiol oxidoreductase & $\mathrm{x}$ & >ref|NP_989441.1| & 81 & $2.00 \mathrm{E}-86$ & $148 / 181$ \\
\hline MCOR0242S & 520 & 1 & $\mathrm{FF}$ & OF & MHC class I protein & $x$ & $>g b|A A A 49389.1|$ & 78 & $9.00 \mathrm{E}-66$ & $114 / 146$ \\
\hline MCOR0243S & 511 & 1 & $P$ & OF & similar to zn-finger & $x$ & $>$ ref $\left|X P \_782581.1\right|$ & 46 & $2.00 \mathrm{E}-36$ & $77 / 167$ \\
\hline MCOR0244S & 536 & 1 & FP & UF & similar to putative membrane protein & $x$ & ref|NP_001002575.1| & 96 & $6.00 \mathrm{E}-90$ & $166 / 172$ \\
\hline MCOR0245S & 563 & 1 & & $\mathrm{NH}$ & no hit & & & & & \\
\hline MCOR0246S & 553 & 1 & $P$ & UF & hypothetical protein XP_787740 & $x$ & >ref|XP_792833.1| & 46 & $3.00 \mathrm{E}-40$ & $84 / 179$ \\
\hline MCOR0247S & 484 & 1 & $P$ & $\mathrm{CM}$ & glucose-fructose oxidoreductase & $x$ & >ref|NP_001028571.1| & 91 & $2.00 \mathrm{E}-53$ & $98 / 107$ \\
\hline MCOR0248S & 540 & 1 & $P$ & DT & Bungarus candidus beta-neurotoxin & $\mathrm{N}$ & $>g b|A Y 425950.1|$ & 93 & $9.00 \mathrm{E}-15$ & $57 / 61$ \\
\hline MCOR0249S & 423 & 1 & FP & $\mathrm{CM}$ & NADH-ubiquinone oxidoreductase B18 & $x$ & sp|Q02368|NB8M_BOVIN & 68 & $6.00 \mathrm{E}-43$ & $80 / 117$ \\
\hline MCOR0250S & 588 & 1 & FP & UF & similar to transmembrane protein & $x$ & $>$ ref $\left|X P \_415767.1\right|$ & 81 & $1.00 \mathrm{E}-79$ & $148 / 182$ \\
\hline MCOR0251S & 591 & 1 & $P$ & CE & epithelial mucin & $x$ & $>\mathrm{gb}|\mathrm{AAB} 48542.1|$ & 40 & $1.00 \mathrm{E}-27$ & $74 / 185$ \\
\hline MCOR0252S & 575 & 1 & FF & CR & calglandulin-like protein & $x$ & sp|Q3SB15|CALGL_OXYSC & 98 & $4.00 \mathrm{E}-84$ & $153 / 156$ \\
\hline MCOR0253S & 301 & 1 & & $\mathrm{NH}$ & no hit & & & & & \\
\hline MCOR0254S & 373 & 1 & $P$ & CT & eukaryotic translation initiation factor & $x$ & >dbj|BAD92356.1| & 92 & $4.00 \mathrm{E}-58$ & $114 / 123$ \\
\hline MCOR0255S & 165 & 1 & & $\mathrm{NH}$ & no hit & & & & & \\
\hline MCOR0256S & 475 & 1 & $P$ & $\mathrm{CR}$ & stromal cell derived factor 4 & $x$ & ref|NP_001006302.1| & 93 & $2.00 \mathrm{E}-83$ & $147 / 158$ \\
\hline MCOR0257S & 417 & 1 & & $\mathrm{NH}$ & no hit & & & & & \\
\hline MCOR0258S & 503 & 1 & $P$ & CR & CSNK2A1 protein & $\mathrm{x}$ & $>\mathrm{gb}|\mathrm{AAH} 50036.1|$ & 97 & $1.00 \mathrm{E}-95$ & $163 / 167$ \\
\hline MCOR0259S & 222 & 1 & $P$ & CT & Nuclease sensitive element-binding protein & $x$ & >ref|NP_989745.1| & 90 & $9.00 \mathrm{E}-34$ & $63 / 70$ \\
\hline MCOR0260S & 169 & 1 & & $\mathrm{NH}$ & no hit & & & & & \\
\hline MCOR0261S & 408 & 1 & FP & CT & ribosomal protein $\mathrm{L} 11$ & $x$ & >emb|CAH71474.1| & 99 & $3.00 \mathrm{E}-72$ & $134 / 135$ \\
\hline MCOR0262S & 228 & 1 & $P$ & $\mathrm{CP}$ & transporter associated with antigen & $x$ & $>$ gb|AAP36717.1| & 60 & $4.00 \mathrm{E}-13$ & $38 / 63$ \\
\hline
\end{tabular}




\begin{tabular}{|c|c|c|c|c|c|c|c|c|c|c|}
\hline CLUSTER & Tamanho $(\mathrm{pb})$ & $\begin{array}{c}N^{\circ} \text { de Clones } \\
\text { no Cluster }\end{array}$ & FULL & $\begin{array}{c}\text { Categoria } \\
\text { 1aria }\end{array}$ & PRODUTO & Blast & Accession $\mathrm{N}^{\circ}$ & $\%$ ID & e-value & overlap \\
\hline MCOR0263S & 506 & 1 & $P$ & TA & L-amino acid oxidase precursor & $\mathrm{x}$ & $>g b|A A Y 89681.1|$ & 81 & $7.00 \mathrm{E}-76$ & $137 / 168$ \\
\hline MCOR0264S & 506 & 1 & $P$ & $C D$ & procollagen (type III) $\mathrm{N}$-endopeptidase & $x$ & >ref|NP_001020611.1| & 96 & $1.00 \mathrm{E}-59$ & $122 / 126$ \\
\hline MCOR0265S & 517 & 1 & FP & $\mathrm{CR}$ & regulator of G-protein signaling protein GAIP & $\mathrm{x}$ & >ref|NP_989560.1| & 86 & $8.00 \mathrm{E}-75$ & $130 / 151$ \\
\hline MCOR0266S & 565 & 1 & & $\mathrm{NH}$ & no hit & & & & & \\
\hline MCOR0267S & 246 & 1 & $\mathrm{FP}$ & UF & hypothetical protein XP_420745 & $\mathrm{x}$ & $>$ ref $\left|X P \_420745.1\right|$ & 93 & $1.00 \mathrm{E}-20$ & $45 / 48$ \\
\hline MCOR0268S & 523 & 1 & & $\mathrm{NH}$ & no hit & & & & & \\
\hline MCOR0269S & 197 & 1 & $P$ & $C D$ & midgut aminopeptidase N2 & $\mathrm{x}$ & $>\mathrm{gb}|\mathrm{AAQ} 24379.1|$ & 52 & $1.00 \mathrm{E}-07$ & $31 / 59$ \\
\hline MCOR0270S & 462 & 1 & $P$ & $\mathrm{RN}$ & Putative rRNA methyltransferase 3 & $\mathrm{x}$ & >sp|Q5ZKM1|RRMJ3_CHICK & 85 & $2.00 \mathrm{E}-67$ & $127 / 148$ \\
\hline MCOR0271S & 513 & 1 & $P$ & OF & MHC class I protein & $\mathrm{x}$ & $>g b|A A A 48519.1|$ & 58 & $4.00 \mathrm{E}-45$ & $85 / 146$ \\
\hline MCOR0272S & 467 & 1 & $P$ & CE & similar to Mucin 5B precursor & $x$ & $>\operatorname{ref}\left|X P \_421033.1\right|$ & 43 & $1.00 \mathrm{E}-28$ & $62 / 141$ \\
\hline MCOR0273S & 387 & 1 & $\mathrm{FP}$ & $\mathrm{TL}$ & C-type lectin-like protein 2 & $x$ & $>g b|A A K 43585.1|$ & 70 & $6.00 \mathrm{E}-48$ & $85 / 121$ \\
\hline MCOR0274S & 363 & 1 & & $\mathrm{NH}$ & no hit & & & & & \\
\hline MCOR0275S & 400 & 1 & & $\mathrm{NH}$ & no hit & & & & & \\
\hline MCOR0276S & 560 & 1 & $\mathrm{FP}$ & UF & Transmembrane emp24 domain & $x$ & >sp|Q9BVK6|TMED9_HUMAN & 90 & $9.00 \mathrm{E}-94$ & $165 / 183$ \\
\hline MCOR0277S & 440 & 1 & $P$ & CE & similar to Filamin A & $x$ & $>$ ref $\left|X P \_538205.2\right|$ & 72 & $2.00 \mathrm{E}-31$ & $62 / 85$ \\
\hline MCOR0278S & 522 & 1 & $P$ & CT & Dr1-associated corepressor & $x$ & sp|Q9D6N5|DRAP1_MOUSE & 67 & $9.00 \mathrm{E}-53$ & $109 / 161$ \\
\hline MCOR0279S & 479 & 1 & $P$ & CE & Ficolin-1 precursor & $\mathrm{x}$ & >ref|NP_001005799.1| & 44 & $6.00 \mathrm{E}-25$ & $69 / 154$ \\
\hline MCOR0280S & 453 & 1 & $P$ & $\mathrm{CR}$ & similar to Thioredoxin-like protein 2 & $x$ & $>$ ref $\left|X P \_421826.1\right|$ & 81 & $3.00 \mathrm{E}-60$ & $113 / 138$ \\
\hline MCOR0281S & 398 & 1 & & $\mathrm{NH}$ & no hit & & & & & \\
\hline MCOR0282S & 304 & 1 & $P$ & OF & coatomer protein complex & $\mathrm{x}$ & $>$ ref|NP_001006339.1| & 83 & $1.00 \mathrm{E}-39$ & $83 / 100$ \\
\hline MCOR0283S & 252 & 1 & $P$ & UF & similar to CG17660-PA isoform 4 & $\mathrm{x}$ & $>$ ref $\left|X P \_707885.1\right|$ & 72 & $4.00 \mathrm{E}-28$ & $58 / 80$ \\
\hline MCOR0284S & 487 & 1 & & $\mathrm{NH}$ & no hit & & & & & \\
\hline MCOR0285S & 293 & 1 & $P$ & VT & Escherichia coli K-12 MG1655 & & $>\mathrm{gb}|\mathrm{AE} 000176.1| \mathrm{AE} 000176$ & 99 & $\mathrm{E}-162$ & $290 / 291$ \\
\hline MCOR0286S & 420 & 1 & $P$ & UF & MGC89502 protein & $x$ & ref|NP_001008127.1| & 95 & $3.00 \mathrm{E}-35$ & $76 / 80$ \\
\hline
\end{tabular}




\begin{tabular}{|c|c|c|c|c|c|c|c|c|c|c|}
\hline CLUSTER & Tamanho (pb) & $\begin{array}{c}N^{\circ} \text { de Clones } \\
\text { no Cluster }\end{array}$ & FULL & $\begin{array}{l}\text { Categoria } \\
\text { 1aria }\end{array}$ & PRODUTO & Blast & Accession $\mathrm{N}^{\circ}$ & $\%$ ID & e-value & overlap \\
\hline MCOR0287S & 433 & 1 & $P$ & $\mathrm{RT}$ & predicted CDS, reverse transcriptase & $x$ & $>$ ref $\left|X P \_781181.1\right|$ & 63 & $9.00 \mathrm{E}-07$ & $21 / 33$ \\
\hline MCOR0288S & 427 & 1 & $P$ & $C D$ & Proteasome activator complex & $x$ & sp|Q4U5R3|PSME1_BOVIN & 56 & $2.00 \mathrm{E}-38$ & $79 / 139$ \\
\hline MCOR0289S & 456 & 1 & $P$ & $\mathrm{CR}$ & similar to FGF intracellular binding & $\mathrm{x}$ & $>$ ref $\left|X P \_533228.2\right|$ & 85 & $6.00 \mathrm{E}-67$ & $124 / 145$ \\
\hline MCOR0290S & 358 & 1 & $P$ & DT & pla2 gene for phospholipase A2 & N & dbj|AB111959.1| & 89 & $1.00 \mathrm{E}-09$ & $57 / 64$ \\
\hline MCOR0291S & 449 & 1 & $P$ & UF & similar to hypothetical protein FLJ10081 & $\mathrm{x}$ & $>$ ref $\left|X P_{-} 424221.1\right|$ & 54 & $5.00 \mathrm{E}-18$ & $54 / 100$ \\
\hline MCOR0292S & 471 & 1 & $P$ & TL & C-type lectin-like protein 2 & $x$ & $>g b|A A K 43585.1|$ & 43 & $5.00 \mathrm{E}-29$ & $64 / 148$ \\
\hline MCOR0293S & 513 & 1 & $P$ & CE & Junctional adhesion molecule A precursor & $\mathrm{x}$ & sp|Q9Y624|JAM1_HUMAN & 46 & $2.00 \mathrm{E}-30$ & $71 / 154$ \\
\hline MCOR0294S & 508 & 1 & FP & CT & Mitochondrial ribosomal protein L16 & $\mathrm{x}$ & ref|NP_060310.1| & 55 & $2.00 \mathrm{E}-36$ & $74 / 133$ \\
\hline MCOR0295S & 507 & 1 & $\mathrm{FP}$ & UF & MGC85236 protein & $\mathrm{x}$ & $>\mathrm{gb}|\mathrm{AAH} 78477.1|$ & 84 & $8.00 \mathrm{E}-40$ & $79 / 94$ \\
\hline MCOR0296S & 562 & 1 & $P$ & MT & Uqcrc2-prov protein & $x$ & $>\mathrm{gb}|\mathrm{AAH} 42931.1|$ & 72 & $1.00 \mathrm{E}-71$ & $131 / 181$ \\
\hline MCOR0297S & 501 & 1 & & $\mathrm{NH}$ & no hit & & & & & \\
\hline MCOR0298S & 474 & 1 & $P$ & CE & similar to beta- 1 syntrophin & $\mathrm{x}$ & ref|NP_001005798.1| & 87 & $1.00 \mathrm{E}-74$ & $137 / 157$ \\
\hline MCOR0299S & 252 & 1 & & $\mathrm{NH}$ & no hit & & & & & \\
\hline MCOR0300S & 501 & 1 & $P$ & OF & similar to vesicle-associated membrane & $x$ & $>$ ref $\left|X P \_581657.1\right|$ & 86 & $1.00 \mathrm{E}-39$ & $78 / 90$ \\
\hline MCOR0301S & 456 & 1 & $\mathrm{FP}$ & CT & eukaryotic translation initiation factor & $\mathrm{x}$ & ref|NP_001013113.1| & 80 & $8.00 \mathrm{E}-64$ & $120 / 150$ \\
\hline MCOR0302S & 525 & 1 & $P$ & OF & Pulmonary surfactant-associated protein & $x$ & sp|P35248|SFTPD_RAT & 41 & $5.00 \mathrm{E}-30$ & $66 / 160$ \\
\hline MCOR0303S & 384 & 1 & $P$ & CE & NAD-dependent deacetylase sirtuin-2 & $\mathrm{x}$ & sp|Q8VDQ8|SIRT2_MOUSE & 65 & $1.00 \mathrm{E}-21$ & $49 / 75$ \\
\hline MCOR0304S & 544 & 1 & $\mathrm{P}$ & $\mathrm{CR}$ & similar to ATP-binding cassette & $x$ & >ref|XP_539916.2| & 65 & $2.00 \mathrm{E}-60$ & $119 / 181$ \\
\hline MCOR0305S & 544 & 1 & $P$ & UF & similar to Reticulocalbin-2 precursor & $\mathrm{x}$ & $>$ ref $\left|X P \_544790.2\right|$ & 76 & $2.00 \mathrm{E}-79$ & $138 / 180$ \\
\hline MCOR0306S & 468 & 1 & $P$ & CT & similar to ribosomal protein S27 & $x$ & $>$ ref|XP_509802.1| & 95 & $1.00 \mathrm{E}-42$ & $81 / 85$ \\
\hline MCOR0307S & 573 & 1 & $P$ & DT & mtlp gene for muscarinic toxin-like protein & $\mathrm{N}$ & >emb|AJ421675.1|BMU421675 & 89 & $\mathrm{E}-137$ & $380 / 423$ \\
\hline MCOR0308S & 569 & 1 & $P$ & CT & UPF2 regulator of nonsense transcripts & $x$ & $>$ ref $\left|X P \_507656.1\right|$ & 73 & $2.00 \mathrm{E}-52$ & $105 / 142$ \\
\hline MCOR0309S & 562 & 1 & $\mathrm{P}$ & UF & Hypothetical protein LOC23065 & $x$ & >gb|AAM88856.1| & 100 & $1.00 \mathrm{E}-13$ & $39 / 39$ \\
\hline MCOR0310S & 579 & 1 & $P$ & UF & similar to FLJ20254 protein & $x$ & $>\operatorname{ref}\left|X P \_426216.1\right|$ & 47 & $2.00 \mathrm{E}-47$ & $84 / 176$ \\
\hline
\end{tabular}




\begin{tabular}{|c|c|c|c|c|c|c|c|c|c|c|}
\hline CLUSTER & Tamanho (pb) & $\begin{array}{c}N^{\circ} \text { de Clones } \\
\text { no Cluster }\end{array}$ & FULL & $\begin{array}{c}\text { Categoria } \\
\text { 1aria }\end{array}$ & PRODUTO & Blast & Accession $\mathrm{N}^{\circ}$ & $\%$ ID & e-value & overlap \\
\hline MCOR0311S & 357 & 1 & $P$ & UF & Nucleolar complex protein 4 homolog & $x$ & sp|Q5ZJC7|NOC4L_CHICK & 63 & $4.00 \mathrm{E}-25$ & $54 / 85$ \\
\hline MCOR0312S & 446 & 1 & $\mathrm{FP}$ & TL & C-type lectin-like protein 2 & $x$ & $>g b|A A K 43585.1|$ & 72 & $6.00 \mathrm{E}-56$ & $96 / 132$ \\
\hline MCOR0313S & 555 & 1 & $P$ & $\mathrm{CR}$ & CMIP protein / c-Maf-inducing protein & $\mathrm{x}$ & $>$ ref $\left|X P \_423491.1\right|$ & 94 & 4.00E-95 & $168 / 178$ \\
\hline MCOR0314S & 527 & 1 & & DT & Ohanin precursor & N & $>\mathrm{gb}|\mathrm{DQ} 103590.1|$ & 88 & $3.00 \mathrm{E}-36$ & $132 / 149$ \\
\hline MCOR0315S & 554 & 1 & FP & $\mathrm{CM}$ & Guanidinoacetate N-methyltransferase & $x$ & >sp|Q71N41|GAMT_BRARE & 77 & $3.00 \mathrm{E}-46$ & $84 / 108$ \\
\hline MCOR0316S & 560 & 1 & $P$ & $\mathrm{CM}$ & methylcrotonoyl-Coenzyme A carboxylase & $x$ & >ref|NP_998092.1| & 80 & 2.00E-71 & $131 / 162$ \\
\hline MCOR0317S & 546 & 1 & $P$ & UF & similar to CG10189-PA isoform 3 & $\mathrm{x}$ & $>$ ref $\left|X P \_850047.1\right|$ & 70 & $1.00 \mathrm{E}-54$ & $103 / 146$ \\
\hline MCOR0318S & 575 & 1 & $P$ & UF & similar to B-cell lymphoma 9 protein & N & $>$ ref $\left|X M \_429583.1\right|$ & 91 & 2.00E-96 & $258 / 283$ \\
\hline MCOR0319S & 554 & 1 & $\mathrm{FP}$ & OF & MHC class II antigen & $\mathrm{x}$ & $>\mathrm{gb}|\mathrm{AAQ} 06509.1|$ & 45 & $4.00 \mathrm{E}-33$ & $75 / 166$ \\
\hline MCOR0320S & 513 & 1 & $\mathrm{FF}$ & UF & hypothetical protein XP_420228 & $x$ & $>\operatorname{ref}\left|X P \_420228.1\right|$ & 93 & $1.00 \mathrm{E}-65$ & $125 / 133$ \\
\hline MCOR0321S & 530 & 1 & $P$ & $\mathrm{CR}$ & v-raf murine sarcoma 3611 viral oncogene & $\mathrm{x}$ & >ref|NP_001014964.1| & 86 & $9.00 \mathrm{E}-53$ & $99 / 115$ \\
\hline MCOR0322S & 538 & 1 & $P$ & CE & paxillin & $x$ & $>$ ref|NP_002850.1| & 99 & 3.00E-95 & $151 / 152$ \\
\hline MCOR0323S & 557 & 1 & $\mathrm{FP}$ & CE & zinc finger protein 184 (Kruppel-like) & $\mathrm{x}$ & >ref|NP_001025866.1| & 61 & $5.00 \mathrm{E}-09$ & $30 / 49$ \\
\hline MCOR0324S & 570 & 1 & $P$ & OF & MHC class I protein & $x$ & gb|AAA48519.1| & 56 & $5.00 \mathrm{E}-51$ & $92 / 163$ \\
\hline MCOR0325S & 532 & 1 & $P$ & UF & Josephin-2 (Josephin domain containing 2) & $\mathrm{x}$ & sp|Q9CR30|JOS2_MOUSE & 78 & $2.00 \mathrm{E}-57$ & $104 / 132$ \\
\hline MCOR0326S & 564 & 1 & $P$ & OF & centromere protein ZW10 / kinetochore & $x$ & $>$ dbj|BAB39105.1| & 61 & $2.00 \mathrm{E}-58$ & $116 / 188$ \\
\hline MCOR0327S & 378 & 1 & $P$ & CT & $40 S$ ribosomal protein $\mathrm{S} 3$ & $\mathrm{x}$ & >gb|AAT01919.1| & 83 & $2.00 \mathrm{E}-25$ & $60 / 72$ \\
\hline MCOR0328S & 472 & 1 & $\mathrm{FP}$ & UF & CLE7 protein & $x$ & $>$ ref|NP_990700.1| & 63 & $5.00 \mathrm{E}-34$ & $71 / 111$ \\
\hline MCOR0329S & 559 & 1 & $P$ & $\mathrm{CM}$ & Pyruvate kinase muscle isozyme & $\mathrm{x}$ & sp|P00548|KPYK_CHICK & 89 & $1.00 \mathrm{E}-47$ & $91 / 102$ \\
\hline MCOR0330S & 538 & 1 & $P$ & OF & TNF receptor-associated protein & $x$ & >ref|NP_001006175.1| & 78 & 2.00E-79 & $136 / 174$ \\
\hline MCOR0331S & 518 & 1 & & $\mathrm{NH}$ & no hit & & & & & \\
\hline MCOR0332S & 567 & 1 & & $\mathrm{NH}$ & no hit & & & & & \\
\hline MCOR0333S & 525 & 1 & $P$ & CT & similar to 60 S ribosomal protein L3-like & $x$ & $>$ ref $\left|X P \_414843.1\right|$ & 84 & $5.00 \mathrm{E}-35$ & $71 / 84$ \\
\hline MCOR0334S & 402 & 1 & & $\mathrm{NH}$ & no hit & & & & & \\
\hline
\end{tabular}




\begin{tabular}{|c|c|c|c|c|c|c|c|c|c|c|}
\hline CLUSTER & Tamanho (pb) & $\begin{array}{c}N^{\circ} \text { de Clones } \\
\text { no Cluster }\end{array}$ & FULL & $\begin{array}{c}\text { Categoria } \\
\text { 1aria }\end{array}$ & PRODUTO & Blast & Accession $\mathrm{N}^{\circ}$ & $\%$ ID & e-value & overlap \\
\hline MCOR0335S & 548 & 1 & $P$ & $\mathrm{CR}$ & ATP-binding cassette, sub-family $F$ & $x$ & >dbj|BAD92801.1| & 93 & 4.00E-93 & $171 / 182$ \\
\hline MCOR0336S & 489 & 1 & $P$ & UF & Hypothetical protein LOC431674 & $x$ & $>\mathrm{gb}|\mathrm{AAH} 67964.1|$ & 73 & $7.00 \mathrm{E}-66$ & $118 / 161$ \\
\hline MCOR0337S & 525 & 1 & $P$ & CT & eukaryotic translation initiation factor & $x$ & $>$ ref|XP_939382.1| & 92 & $1.00 \mathrm{E}-81$ & $152 / 165$ \\
\hline MCOR0338S & 517 & 1 & $P$ & $\mathrm{CR}$ & erthyrocyte band 7 integral membrane & $x$ & ref|NP_001011965.1| & 92 & $7.00 \mathrm{E}-33$ & $75 / 81$ \\
\hline MCOR0339S & 563 & 1 & $\mathrm{FP}$ & $\mathrm{CM}$ & inosine monophosphate dehydrogenase & $\mathrm{x}$ & >ref|NP_001025772.1| & 92 & $2.00 \mathrm{E}-93$ & $166 / 179$ \\
\hline MCOR0340S & 368 & 1 & $P$ & UF & microsatellite MV4008 sequence & $\mathrm{N}$ & $>g b|A F 236360.1|$ & 95 & $8.00 \mathrm{E}-08$ & $39 / 41$ \\
\hline MCOR0341S & 578 & 1 & $P$ & CT & muscle, intestine and stomach expression & $\mathrm{x}$ & $>$ ref $\left|X P \_425228.1\right|$ & 65 & $2.00 \mathrm{E}-43$ & $95 / 144$ \\
\hline MCOR0342S & 568 & 1 & $P$ & RT & reverse transcriptase-like protein & $\mathrm{x}$ & $>g b|A A N 15747.1|$ & 42 & $1.00 \mathrm{E}-34$ & $82 / 192$ \\
\hline MCOR0343S & 578 & 1 & $P$ & CT & DEAH (Asp-Glu-Ala-His) box polypeptide 16 & $\mathrm{x}$ & ref|NP_956318.1| & 93 & $E-100$ & $180 / 192$ \\
\hline MCOR0344S & 521 & 1 & & $\mathrm{NH}$ & no hit & & & & & \\
\hline MCOR0345S & 580 & 1 & $P$ & $\mathrm{CP}$ & Sec61 alpha 1 subunit & $x$ & emb|CAJ82441.1| & 98 & $1.00 \mathrm{E}-68$ & $132 / 134$ \\
\hline MCOR0346S & 555 & 1 & & $\mathrm{NH}$ & no hit & & & & & \\
\hline MCOR0347S & 534 & 1 & $\mathrm{FP}$ & TL & C-type lectin-like protein 2 & $x$ & $>g b|A A K 43585.1|$ & 63 & $1.00 \mathrm{E}-41$ & $78 / 123$ \\
\hline MCOR0348S & 595 & 1 & $P$ & $\mathrm{CM}$ & ATP synthase, $\mathrm{H}+$ transporting & $x$ & $>\mathrm{gb}|\mathrm{AAH} 11384.1|$ & 99 & E-105 & $196 / 197$ \\
\hline MCOR0349S & 503 & 1 & $\mathrm{FF}$ & UF & hypothetical protein LOC428592 & $x$ & >ref|NP_001026695.1| & 89 & $2.00 \mathrm{E}-51$ & $95 / 106$ \\
\hline MCOR0350S & 529 & 1 & $P$ & CT & splicing factor, arginine/serine-rich 2 & N & >ref|NM_001034118.1| & 98 & $6.00 \mathrm{E}-59$ & $125 / 127$ \\
\hline MCOR0351S & 244 & 1 & $P$ & CD & ubiquitin & $\mathrm{x}$ & $>g b|A A V 84266.1|$ & 100 & $4.00 \mathrm{E}-38$ & $80 / 80$ \\
\hline MCOR0352S & 545 & 1 & FP & CR & Chloride intracellular channel protein & $x$ & emb|CAl18421.1| & 90 & $5.00 \mathrm{E}-78$ & $142 / 157$ \\
\hline MCOR0353S & 436 & 1 & $P$ & $\mathrm{CM}$ & similar to alcohol dehydrogenase $\mathrm{ADH}-\mathrm{F}$ & $x$ & $>$ ref $\left|X P \_420658.1\right|$ & 77 & $1.00 \mathrm{E}-62$ & $110 / 142$ \\
\hline MCOR0354S & 534 & 1 & $P$ & OF & Craniofacial development protein 1 & $\mathrm{x}$ & sp|Q75QIO|CFDP1_CHICK & 50 & $3.00 \mathrm{E}-34$ & $86 / 172$ \\
\hline MCOR0355S & 544 & 1 & $P$ & $\mathrm{CP}$ & similar to Protein disulfide isomerase & $\mathrm{x}$ & $>$ ref $\left|X P_{-} 419952.1\right|$ & 89 & $7.00 \mathrm{E}-77$ & $140 / 157$ \\
\hline MCOR0356S & 538 & 1 & $P$ & UF & LOC51136 protein & $\mathrm{x}$ & $>\mathrm{gb}|\mathrm{AAH} 88365.1|$ & 67 & $2.00 \mathrm{E}-56$ & $97 / 144$ \\
\hline MCOR0357S & 580 & 1 & $P$ & $\mathrm{CR}$ & similar to Component of oligomeric golgi & $x$ & >ref|XP_239373.3| & 54 & $2.00 \mathrm{E}-55$ & $107 / 195$ \\
\hline MCOR0358S & 538 & 1 & $P$ & $\mathrm{CR}$ & Mitogen-activated protein kinase 3 & $x$ & ref|NP_958915.1| & 94 & $1.00 \mathrm{E}-95$ & $165 / 175$ \\
\hline
\end{tabular}




\begin{tabular}{|c|c|c|c|c|c|c|c|c|c|c|}
\hline CLUSTER & Tamanho (pb) & $\begin{array}{c}N^{\circ} \text { de Clones } \\
\text { no Cluster }\end{array}$ & FULL & $\begin{array}{c}\text { Categoria } \\
\text { 1aria }\end{array}$ & PRODUTO & Blast & Accession $\mathrm{N}^{\circ}$ & $\%$ ID & e-value & overlap \\
\hline MCOR0359S & 465 & 1 & & $\mathrm{NH}$ & no hit & & & & & \\
\hline MCOR0360S & 525 & 1 & & $\mathrm{NH}$ & no hit & & & & & \\
\hline MCOR0361S & 536 & 1 & $P$ & $\mathrm{CP}$ & vacuolar protein sorting homolog h-vps 45 & $x$ & $>g b|A A C 50931.1|$ & 80 & $1.00 \mathrm{E}-65$ & $122 / 151$ \\
\hline MCOR0362S & 195 & 1 & $P$ & OF & Annexin A2 (Annexin II) (Lipocortin II) & $x$ & sp|P17785|ANXA2_CHICK & 85 & $4.00 \mathrm{E}-24$ & $55 / 64$ \\
\hline MCOR0363S & 544 & 1 & $P$ & $\mathrm{CR}$ & [3-methyl-2-oxobutanoate dehydrogenase & $x$ & $>\mathrm{gb}|\mathrm{AAH} 04077.1|$ & 92 & $2.00 \mathrm{E}-95$ & $168 / 181$ \\
\hline MCOR0364S & 533 & 1 & & $\mathrm{NH}$ & no hit & & & & & \\
\hline MCOR0365S & 480 & 1 & $\mathrm{P}$ & CT & mitochondrial ribosomal protein L51 & $x$ & ref|NP_001008675.1| & 72 & $3.00 \mathrm{E}-40$ & $72 / 99$ \\
\hline MCOR0366S & 470 & 1 & $P$ & DT & mRNA for protease A, complete cds & N & $>d b j|A B 031394.1|$ & 90 & $5.00 \mathrm{E}-13$ & $67 / 74$ \\
\hline MCOR0367S & 559 & 1 & $P$ & CT & Eukaryotic translation initiation factor $5 \mathrm{~A}$ & $x$ & >sp|P10160|IF5A_RABIT & 99 & $8.00 \mathrm{E}-53$ & $103 / 104$ \\
\hline MCOR0368S & 435 & 1 & & $\mathrm{NH}$ & no hit & & & & & \\
\hline MCOR0369S & 546 & 1 & $P$ & OF & similar to peptidylglycine alpha-amidating & $x$ & $>$ ref $\left|X P \_424857.1\right|$ & 82 & $5.00 \mathrm{E}-86$ & $147 / 178$ \\
\hline MCOR0370S & 475 & 1 & FF & UF & similar to RIKEN cDNA 0610009E20 & $x$ & $>$ ref $\left|X P \_415849.1\right|$ & 95 & $2.00 \mathrm{E}-54$ & $105 / 110$ \\
\hline MCOR0371S & 496 & 1 & $P$ & CT & Eukaryotic translation initiation factor 3 & $x$ & >emb|CAG33415.1| & 98 & $9.00 \mathrm{E}-91$ & $163 / 165$ \\
\hline MCOR0372S & 532 & 1 & FP & $\mathrm{CP}$ & similar to TRAP-complex gamma subunit & $x$ & $>\operatorname{ref}\left|X P \_422829.1\right|$ & 93 & $2.00 \mathrm{E}-88$ & $166 / 177$ \\
\hline MCOR0373S & 562 & 1 & $P$ & MT & similar to cytochrome c oxidase subunit & $x$ & $>$ ref $\left|X P \_419450.1\right|$ & 63 & $7.00 \mathrm{E}-36$ & $76 / 120$ \\
\hline MCOR0374S & 488 & 1 & $P$ & $\mathrm{CM}$ & ATPase, $\mathrm{H}+$ transporting, lysosomal & $x$ & ref|NP_001017064.1| & 93 & 7.00E-08 & $30 / 32$ \\
\hline MCOR0375S & 304 & 1 & & $\mathrm{NH}$ & no hit & & & & & \\
\hline MCOR0376S & 539 & 1 & $P$ & CE & similar to Filamin A (Alpha-filamin) & $x$ & $>$ ref $\left|X P \_538205.2\right|$ & 74 & $7.00 \mathrm{E}-58$ & $106 / 143$ \\
\hline MCOR0377S & 380 & 1 & $P$ & $\mathrm{CM}$ & Glycogen phosphorylase, muscle form & $x$ & sp|P11217|PYGM_HUMAN & 82 & $8.00 \mathrm{E}-61$ & $109 / 132$ \\
\hline MCOR0378S & 533 & 1 & FP & $\mathrm{CM}$ & Fructose-1,6-bisphosphatase 1 & $x$ & $>$ ref $\left|X P \_425040.1\right|$ & 87 & $2.00 \mathrm{E}-68$ & $130 / 148$ \\
\hline MCOR0379S & 443 & 1 & $P$ & $\mathrm{CE}$ & actin related protein $2 / 3$ complex & $x$ & ref|NP_998321.1| & 92 & $3.00 \mathrm{E}-57$ & $100 / 108$ \\
\hline MCOR0380S & 451 & 1 & $\mathrm{FP}$ & UF & DCN1-like protein 4 & $x$ & >sp|Q92564|DCNL4_HUMAN & 87 & $6.00 \mathrm{E}-61$ & $109 / 125$ \\
\hline MCOR0381S & 340 & 1 & $P$ & CT & similar to $40 S$ ribosomal protein $\mathrm{S} 4$ & $x$ & $>\mathrm{gb}|\mathrm{AAH} 07308.2|$ & 83 & $2.00 \mathrm{E}-47$ & $94 / 112$ \\
\hline MCOR0382S & 296 & 1 & $P$ & TP & phospholipase A2 & $x$ & $>$ gb|AAN60018.1| & 100 & $2.00 \mathrm{E}-37$ & $68 / 68$ \\
\hline
\end{tabular}




\begin{tabular}{|c|c|c|c|c|c|c|c|c|c|c|}
\hline CLUSTER & Tamanho $(\mathrm{pb})$ & $\begin{array}{c}N^{\circ} \text { de Clones } \\
\text { no Cluster }\end{array}$ & FULL & $\begin{array}{c}\text { Categoria } \\
\text { 1aria }\end{array}$ & PRODUTO & Blast & Accession $\mathrm{N}^{\circ}$ & $\%$ ID & e-value & overlap \\
\hline MCOR0383S & 536 & 1 & $\mathrm{FF}$ & $C D$ & Chain A, Solution Structure Of Mouse & $x$ & $\mathrm{pdb}|1 \mathrm{~J} 0 \mathrm{G}| \mathrm{A}$ & 95 & $2.00 \mathrm{E}-38$ & $80 / 84$ \\
\hline MCOR0384S & 522 & 1 & & $\mathrm{NH}$ & no hit & & & & & \\
\hline MCOR0385S & 545 & 1 & $P$ & CE & cytoplasmic actin type 5 & $\mathrm{x}$ & $>$ gb|AAQ18433.1| & 100 & $3.00 \mathrm{E}-63$ & $118 / 118$ \\
\hline MCOR0386S & 537 & 1 & & $\mathrm{NH}$ & no hit & & & & & \\
\hline MCOR0387S & 535 & 1 & $\mathrm{FF}$ & OF & chemokine / interleukin-8 variant 3 & $x$ & $>g b|A A Q 01586.1|$ & 29 & $9.00 \mathrm{E}-06$ & $26 / 88$ \\
\hline MCOR0388S & 409 & 1 & & $\mathrm{NH}$ & no hit & & & & & \\
\hline MCOR0389S & 464 & 1 & $P$ & $\mathrm{CP}$ & vacuolar protein sorting $45 \mathrm{~A}$ variant & $x$ & >dbj|BAD96934.1| & 92 & $7.00 \mathrm{E}-76$ & $142 / 153$ \\
\hline MCOR0390S & 485 & 1 & & $\mathrm{NH}$ & no hit & & & & & \\
\hline MCOR0391S & 424 & 1 & $P$ & CR & guanine nucleotide binding proteinrotein & $x$ & $>$ ref $\left|X P \_518165.1\right|$ & 98 & $1.00 \mathrm{E}-62$ & $117 / 119$ \\
\hline MCOR0392S & 383 & 1 & $P$ & $\mathrm{CM}$ & fumarylacetoacetate hydrolase domain & $x$ & >emb|CAJ81463.1| & 68 & $1.00 \mathrm{E}-40$ & $83 / 122$ \\
\hline MCOR0393S & 530 & 1 & $\mathrm{FP}$ & $\mathrm{CM}$ & Adenylate kinase isoenzyme 1 & $\mathrm{x}$ & sp|P05081|KAD1_CHICK & 91 & $2.00 \mathrm{E}-78$ & $148 / 162$ \\
\hline MCOR0394S & 421 & 1 & $P$ & $\mathrm{CM}$ & Fructose 1,6-Bisphosphate Aldolase & $\mathrm{x}$ & $\mathrm{pdb}|1 \mathrm{EWD}| \mathrm{A}$ & 86 & $9.00 \mathrm{E}-60$ & $115 / 133$ \\
\hline MCOR0395S & 378 & 1 & $P$ & $\mathrm{CP}$ & chaperone for superoxide dismutase & $\mathrm{x}$ & sp|Q9WU84|CCS_MOUSE & 60 & $5.00 \mathrm{E}-37$ & $76 / 125$ \\
\hline MCOR0396S & 359 & 1 & $P$ & UF & Hypothetical protein CBG02169 & $x$ & >emb|CAE58912.1| & 81 & $2.00 \mathrm{E}-23$ & $49 / 60$ \\
\hline MCOR0397S & 409 & 1 & $P$ & UF & putative Ariadne-like ubiquitin ligase PAUL & $\mathrm{x}$ & $>$ gb|AAQ55547.1| & 81 & $6.00 \mathrm{E}-64$ & $103 / 126$ \\
\hline MCOR0398S & 499 & 1 & & $\mathrm{NH}$ & no hit & & & & & \\
\hline MCOR0399S & 473 & 1 & & $\mathrm{NH}$ & no hit & & & & & \\
\hline MCOR0400S & 374 & 1 & $\mathrm{FP}$ & CE & alpha actin & $x$ & $>g b|A A U 25922.1|$ & 91 & $5.00 \mathrm{E}-31$ & $64 / 70$ \\
\hline MCOR0401S & 349 & 1 & & $\mathrm{NH}$ & no hit & & & & & \\
\hline MCOR0402S & 525 & 1 & & $\mathrm{NH}$ & no hit & & & & & \\
\hline MCOR0403S & 192 & 1 & $P$ & $C D$ & membrane-bound aminopeptidase $P$ & $\mathrm{x}$ & $>g b|A A K 52065.1|$ & 85 & $1.00 \mathrm{E}-25$ & $51 / 60$ \\
\hline MCOR0404S & 504 & 1 & $P$ & TP & phospholipase A2 & $x$ & $>\mathrm{gb} \mid$ AAN60018.1| & 76 & $1.00 \mathrm{E}-68$ & $127 / 167$ \\
\hline MCOR0405S & 401 & 1 & $P$ & $\mathrm{CR}$ & $\mathrm{N}$-acetylglucosamine kinase & $x$ & ref|NP_001032857.1| & 72 & $9.00 \mathrm{E}-47$ & $87 / 120$ \\
\hline MCOR0406S & 428 & 1 & $P$ & CR & ADP-ribosylhydrolase like 2 & $x$ & >ref|NP_001006312.1| & 78 & $2.00 \mathrm{E}-56$ & $110 / 140$ \\
\hline
\end{tabular}




\begin{tabular}{|c|c|c|c|c|c|c|c|c|c|c|}
\hline CLUSTER & Tamanho (pb) & $\begin{array}{c}N^{\circ} \text { de Clones } \\
\text { no Cluster }\end{array}$ & FULL & $\begin{array}{c}\text { Categoria } \\
\text { 1aria } \\
\end{array}$ & PRODUTO & Blast & Accession $\mathrm{N}^{\circ}$ & $\%$ ID & e-value & overlap \\
\hline MCOR0407S & 188 & 1 & $P$ & CT & similar to ribosomal protein S27 isoform 2 & $\mathrm{x}$ & $>$ ref $\mid X P \_886008.1$ & 95 & $2.00 \mathrm{E}-20$ & $45 / 47$ \\
\hline MCOR0408S & 423 & 1 & $P$ & $\mathrm{CP}$ & Sec61a1-prov protein & $\mathrm{x}$ & $>\mathrm{gb}|\mathrm{AAH} 45117.1|$ & 92 & $1.00 \mathrm{E}-68$ & $128 / 138$ \\
\hline MCOR0409S & 424 & 1 & $P$ & CT & $40 S$ ribosomal protein $\mathrm{S} 27$ & $x$ & sp|P47904|RS27_XENLA & 85 & $2.00 \mathrm{E}-32$ & $64 / 75$ \\
\hline MCOR0410S & 467 & 1 & $\mathrm{FP}$ & $\mathrm{CP}$ & similar to Metaxin 2 & $x$ & ref $\left|X P \_421989.1\right|$ & 89 & $3.00 \mathrm{E}-70$ & $132 / 148$ \\
\hline MCOR0411S & 397 & 1 & $P$ & CT & eukaryotic translation elongation factor & $x$ & $>g b|A A V 66397.1|$ & 89 & $6.00 \mathrm{E}-59$ & $114 / 128$ \\
\hline MCOR0412S & 254 & 1 & $P$ & CT & $60 S$ ribosomal protein $\mathrm{L} 3$ & $\mathrm{x}$ & gb|AAH09655.1| & 21 & $3.00 \mathrm{E}-38$ & $76 / 83$ \\
\hline MCOR0413S & 184 & 1 & & $\mathrm{NH}$ & no hit & & & & & \\
\hline MCOR0414S & 386 & 1 & $\mathrm{FP}$ & CR & similar to $S 100$ calcium binding protein & $x$ & ref|XP_547580.1| & 59 & $1.00 \mathrm{E}-21$ & $57 / 96$ \\
\hline MCOR0415S & 487 & 1 & $P$ & OF & solute carrier family 26 , member 11 & $x$ & >ref|NP_001014866.1| & 77 & $3.00 \mathrm{E}-63$ & $125 / 162$ \\
\hline MCOR0416S & 497 & 1 & FF & CT & $40 S$ ribosomal protein $\mathrm{S} 14$ & $\mathrm{x}$ & sp|P62263|RS14_HUMAN & 99 & $2.00 \mathrm{E}-79$ & $148 / 149$ \\
\hline MCOR0417S & 508 & 1 & $P$ & $\mathrm{CR}$ & similar to Diablo homolog, mitochondrial & $x$ & $>$ ref $\left|X P_{-} 415152.1\right|$ & 82 & $5.00 \mathrm{E}-66$ & $130 / 157$ \\
\hline MCOR0418S & 322 & 1 & $P$ & $C D$ & poly-ubiquitin precursor & $\mathrm{x}$ & $>g b|A A A 31133.1|$ & 100 & $7.00 \mathrm{E}-39$ & $81 / 81$ \\
\hline MCOR0419S & 494 & 1 & $P$ & CE & putative collagen alpha-2 $(\mathrm{XI})$ chain & $\mathrm{x}$ & $>g b|A A A 67751.1|$ & 50 & $1.00 \mathrm{E}-31$ & $66 / 130$ \\
\hline MCOR0420S & 525 & 1 & & $\mathrm{NH}$ & no hit & & & & & \\
\hline MCOR0421S & 540 & 1 & & $\mathrm{NH}$ & no hit & & & & & \\
\hline MCOR0422S & 500 & 1 & $P$ & CE & Keratin, type I cytoskeletal 19 & $x$ & sp|O93256|K1C19_CHICK & 85 & $2.00 \mathrm{E}-74$ & $142 / 166$ \\
\hline MCOR0423S & 426 & 1 & $\mathrm{FP}$ & $\mathrm{CR}$ & similar to recombination protein $\mathrm{REC} 14$ & $\mathrm{x}$ & $>$ ref $\left|X P \_413745.1\right|$ & 90 & $2.00 \mathrm{E}-66$ & $117 / 129$ \\
\hline MCOR0424S & 469 & 1 & $P$ & $\mathrm{CM}$ & muscle phosphofructokinase & $\mathrm{x}$ & >ref|NP_989554.1| & 84 & $5.00 \mathrm{E}-59$ & $105 / 124$ \\
\hline MCOR0425S & 526 & 1 & $P$ & OF & Annexin A2 (Annexin II) (Lipocortin II) & $\mathrm{x}$ & sp|P17785|ANXA2_CHICK & 94 & $2.00 \mathrm{E}-86$ & $156 / 165$ \\
\hline MCOR0426S & 319 & 1 & & $\mathrm{NH}$ & no hit & & & & & \\
\hline MCOR0427S & 542 & 1 & $P$ & OF & 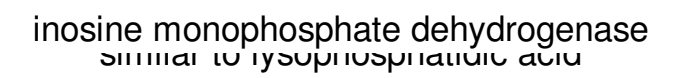 & $x$ & >ref|NP_001025772.1| & 97 & $1.00 \mathrm{E}-95$ & $176 / 180$ \\
\hline MCOR0428S & 159 & 1 & $P$ & OF & acyltransferase & $\mathrm{x}$ & $>$ ref $\left|X P_{-} 415422.1\right|$ & 78 & $1.00 \mathrm{E}-18$ & $41 / 52$ \\
\hline MCOR0429S & 424 & 1 & $P$ & CT & similar to Transcription factor BTF3 & $x$ & $>$ ref $\left|X P \_423823.1\right|$ & 95 & $3.00 \mathrm{E}-66$ & $133 / 139$ \\
\hline MCOR0430S & 428 & 1 & $P$ & OF & nicastrin & $x$ & $>g b|A A R 25612.1|$ & 62 & $2.00 \mathrm{E}-44$ & $92 / 147$ \\
\hline
\end{tabular}




\begin{tabular}{|c|c|c|c|c|c|c|c|c|c|c|}
\hline CLUSTER & Tamanho (pb) & $\begin{array}{c}N^{\circ} \text { de Clones } \\
\text { no Cluster }\end{array}$ & FULL & $\begin{array}{c}\text { Categoria } \\
\text { 1aria } \\
\end{array}$ & PRODUTO & Blast & Accession $\mathrm{N}^{\circ}$ & $\%$ ID & e-value & overlap \\
\hline MCOR0431S & 553 & 1 & $\mathrm{FP}$ & CT & similar to RD RNA-binding protein isoform & $\mathrm{x}$ & ref|XP_591872.2| & 70 & $9.00 \mathrm{E}-52$ & $111 / 157$ \\
\hline MCOR0432S & 562 & 1 & $P$ & CT & Sf3b3 protein / Splicing factor $3 b$, subunit 3 & $\mathrm{x}$ & $>\mathrm{gb}|\mathrm{AAH} 31197.2|$ & 100 & $3.00 \mathrm{E}-75$ & $137 / 137$ \\
\hline MCOR0433S & 420 & 1 & $P$ & CE & similar to protocadherin 17 ; protocadherin & $x$ & $>$ ref $\left|X P \_417021.1\right|$ & 94 & 7.00E-76 & $132 / 139$ \\
\hline MCOR0434S & 518 & 1 & $\mathrm{FP}$ & CT & SWI/SNF related, matrix associated & $x$ & sp|Q5ZK40|SNF5_CHICK & 96 & $1.00 \mathrm{E}-93$ & $165 / 171$ \\
\hline MCOR0435S & 532 & 1 & $\mathrm{FP}$ & OF & similar to B-cell receptor-associated protein & $x$ & $>$ ref $\left|X P \_538200.1\right|$ & 79 & $5.00 \mathrm{E}-73$ & $140 / 177$ \\
\hline MCOR0436S & 508 & 1 & $P$ & RT & similar to reverse transcriptase like family & $\mathrm{x}$ & $>$ ref $\mid X P_{-}$783162.1| & 38 & $1.00 \mathrm{E}-14$ & $43 / 112$ \\
\hline MCOR0437S & 559 & 1 & $P$ & CT & eukaryotic translation inititation factor $4 \mathrm{~B}$ & $x$ & $>g b|A A L 54908.1|$ & 98 & e-101 & $180 / 183$ \\
\hline MCOR0438S & 370 & 1 & $\mathrm{FF}$ & CT & $60 S$ ribosomal protein L39 & $x$ & sp|Q98TF5|RL39_CHICK & 100 & $2.00 \mathrm{E}-23$ & $51 / 51$ \\
\hline MCOR0439S & 478 & 1 & $\mathrm{FP}$ & $\mathrm{CR}$ & Calgizzarin & $x$ & sp|P24479|S10AB_CHICK & 85 & $9.00 \mathrm{E}-37$ & $76 / 89$ \\
\hline MCOR0440S & 533 & 1 & $P$ & OF & similar to nuclease sensitive element & $\mathrm{x}$ & $>$ ref $\left|X P \_848660.1\right|$ & 84 & $7.00 \mathrm{E}-10$ & $32 / 38$ \\
\hline MCOR0441S & 495 & 1 & $\mathrm{FF}$ & CT & similar to ribosomal protein S24 & $\mathrm{x}$ & ref $\left|X P \_864468.1\right|$ & 96 & 7.00E-67 & $125 / 130$ \\
\hline MCOR0442S & 521 & 1 & $P$ & $\mathrm{CM}$ & Phosphoglycerate mutase 2 & $\mathrm{x}$ & sp|P15259|PGAM2_HUMAN & 83 & $6.00 \mathrm{E}-78$ & $141 / 168$ \\
\hline MCOR0443S & 482 & 1 & $P$ & DT & Snake BP-II gene for phospholipase A2 & N & dbj|D13384.1|TFLPLABPII & 89 & 4.00E-26 & $97 / 108$ \\
\hline MCOR0444S & 408 & 1 & FF & TNtx & Alpha-neurotoxin homolog 7 precursor & $\mathrm{x}$ & sp|Q9PRI1|NXAH7_MICCO & 85 & $8.00 \mathrm{E}-35$ & $67 / 78$ \\
\hline MCOR0445S & 433 & 1 & $P$ & TNtx & alpha neurotoxin homolog $3(\mathrm{NXH} 3)$ & N & $>\mathrm{gb}|\mathrm{AF} 197564.1| \mathrm{AF} 197564$ & 92 & e-121 & $398 / 432$ \\
\hline MCOR0446S & 452 & 1 & & $\mathrm{NH}$ & no hit & & & & & \\
\hline MCOR0447S & 153 & 1 & & $\mathrm{NH}$ & no hit & & & & & \\
\hline MCOR0448S & 473 & 1 & FF & CT & similar to $60 S$ acidic ribosomal protein & $x$ & $>$ ref $\left|X P \_424134.1\right|$ & 93 & $5.00 \mathrm{E}-52$ & $107 / 115$ \\
\hline MCOR0449S & 544 & 1 & $\mathrm{FF}$ & OF & Parvalbumin beta & $x$ & >sp|P02615|PRVB_BOACO & 87 & $4.00 \mathrm{E}-47$ & $95 / 108$ \\
\hline MCOR0450S & 386 & 1 & $P$ & $C D$ & $26 S$ proteasome subunit & $\mathrm{x}$ & dbj|BAD93292.1| & 87 & $1.00 \mathrm{E}-23$ & $54 / 62$ \\
\hline MCOR0451S & 493 & 1 & $P$ & DT & Ohanin precursor, gene & N & $>g b|D Q 103590.1|$ & 91 & $8.00 \mathrm{E}-49$ & $141 / 154$ \\
\hline MCOR0452S & 388 & 1 & $P$ & OF & Copz1 protein / similar to Coatomer & $x$ & $>g b|A A H 25041.1|$ & 91 & $3.00 \mathrm{E}-56$ & $109 / 119$ \\
\hline MCOR0453S & 493 & 1 & $P$ & DT & Ohanin precursor, gene, complete cds & $\mathrm{N}$ & $>g b|D Q 103590.1|$ & 93 & $5.00 \mathrm{E}-07$ & $41 / 44$ \\
\hline MCOR0454S & 361 & 1 & $P$ & TNtx & mRNA for short chain neurotoxin & $\mathrm{N}$ & $>d b j|A B 017945.1|$ & 98 & $4.00 \mathrm{E}-56$ & $120 / 122$ \\
\hline
\end{tabular}




\begin{tabular}{|c|c|c|c|c|c|c|c|c|c|c|}
\hline CLUSTER & Tamanho (pb) & $\begin{array}{c}N^{\circ} \text { de Clones } \\
\text { no Cluster }\end{array}$ & FULL & $\begin{array}{c}\text { Categoria } \\
\text { 1aria } \\
\end{array}$ & PRODUTO & Blast & Accession $\mathrm{N}^{\circ}$ & $\%$ ID & e-value & overlap \\
\hline MCOR0455S & 322 & 1 & $P$ & TNtx & Alpha-neurotoxin homolog 7 precursor & $\mathrm{x}$ & sp|Q9PRI1|NXAH7_MICCO & 100 & $1.00 \mathrm{E}-23$ & $49 / 49$ \\
\hline MCOR0456S & 387 & 1 & $P$ & CT & ribosomal protein L14 & $\mathrm{x}$ & gb|AAL54903.1| & 78 & $2.00 \mathrm{E}-35$ & $81 / 103$ \\
\hline MCOR0457S & 366 & 1 & $P$ & CE & similar to Alpha-tectorin precursor & $x$ & $>$ ref $\left|X P \_546475.2\right|$ & 42 & $3.00 \mathrm{E}-19$ & $47 / 111$ \\
\hline MCOR0458S & 550 & 1 & $P$ & CT & elongation factor RNA polymerase II & $\mathrm{x}$ & ref|NP_001012865.1| & 77 & $1.00 \mathrm{E}-68$ & $133 / 172$ \\
\hline MCOR0459S & 577 & 1 & & $\mathrm{NH}$ & no hit & & & & & \\
\hline MCOR0460S & 262 & 1 & $P$ & MT & cytochrome oxidase subunit 3 & $\mathrm{x}$ & ref|YP_313713.1| & 83 & $9.00 \mathrm{E}-26$ & $59 / 71$ \\
\hline MCOR0461S & 587 & 1 & $\mathrm{FP}$ & CE & zinc finger protein 593 & $x$ & >ref|NP_001006307.1| & 79 & $2.00 \mathrm{E}-54$ & $102 / 128$ \\
\hline MCOR0462S & 177 & 1 & $P$ & TNtx & muscarinic toxin precursor & $x$ & gb|ABB83639.1| & 58 & $3.00 \mathrm{E}-06$ & $27 / 46$ \\
\hline MCOR0463S & 534 & 1 & $P$ & $C D$ & Proteasome (prosome, macropain) $26 \mathrm{~S}$ & $x$ & $>\mathrm{gb}|\mathrm{AAH} 73165.1|$ & 96 & $5.00 \mathrm{E}-67$ & $128 / 133$ \\
\hline MCOR0464S & 380 & 1 & $P$ & TNtx & muscarinic toxin precursor & $\mathrm{x}$ & $>g b|A B B 83639.1|$ & 43 & $3.00 \mathrm{E}-09$ & $32 / 74$ \\
\hline MCOR0465S & 458 & 1 & $P$ & UF & unnamed protein product & $x$ & $>$ dbj|BAB70838.1| & 60 & $1.00 \mathrm{E}-06$ & $25 / 41$ \\
\hline MCOR0466S & 334 & 1 & $P$ & CT & similar to $60 S$ ribosomal protein L8 & $\mathrm{x}$ & $>$ ref $\left|X P \_416772.1\right|$ & 95 & $5.00 \mathrm{E}-55$ & $105 / 110$ \\
\hline MCOR0467S & 366 & 1 & $\mathrm{FP}$ & TP & phospholipase A2 & $x$ & $>g b \mid$ AAN60018.1| & 85 & $5.00 \mathrm{E}-56$ & $101 / 118$ \\
\hline MCOR0468S & 542 & 1 & $P$ & RT & predicted CDS, reverse transcriptase & $\mathrm{x}$ & $>$ ref|XP_780819.1| & 45 & $3.00 \mathrm{E}-10$ & $45 / 98$ \\
\hline MCOR0469S & 522 & 1 & & $\mathrm{NH}$ & no hit & & & & & \\
\hline MCOR0470S & 431 & 1 & FF & $\mathrm{TNtx}$ & Alpha-neurotoxin homolog 7 precursor & $\mathrm{x}$ & sp|Q9PRI1|NXAH7_MICCO & 97 & $8.00 \mathrm{E}-40$ & $76 / 78$ \\
\hline MCOR0471S & 545 & 1 & $P$ & $\mathrm{CR}$ & interferon, gamma-inducible protein 30 & $\mathrm{x}$ & >ref|NP_001017196.1| & 58 & $6.00 \mathrm{E}-58$ & $106 / 180$ \\
\hline MCOR0472S & 343 & 1 & & $\mathrm{NH}$ & no hit & & & & & \\
\hline MCOR0473S & 534 & 1 & $\mathrm{FF}$ & CT & ribosomal protein $\mathrm{S} 10$ & $x$ & sp|P46783|RS10_HUMAN & 98 & $6.00 \mathrm{E}-90$ & $159 / 161$ \\
\hline MCOR0474S & 554 & 1 & $P$ & $C D$ & similar to Microsomal signal peptidase & $x$ & ref|XP_417247.1| & 90 & $2.00 \mathrm{E}-93$ & $166 / 183$ \\
\hline MCOR0475S & 334 & 1 & $P$ & UF & hypothetical protein XP_498725 & $x$ & ref|XP_498725.2| & 65 & $6.00 \mathrm{E}-19$ & $47 / 72$ \\
\hline MCOR0476S & 428 & 1 & $\mathrm{FF}$ & $\mathrm{TNtx}$ & Alpha-neurotoxin homolog 7 precursor & $x$ & sp|Q9PRI1|NXAH7_MICCO & 100 & $4.00 \mathrm{E}-41$ & $78 / 78$ \\
\hline MCOR0477S & 578 & 1 & & $\mathrm{NH}$ & no hit & & & & & \\
\hline MCOR0478S & 463 & 1 & $P$ & CT & similar to endothelial differentiation & $x$ & $>$ ref $\left|X P \_537793.2\right|$ & 85 & 4.00E-65 & $126 / 147$ \\
\hline
\end{tabular}




\begin{tabular}{|c|c|c|c|c|c|c|c|c|c|c|}
\hline CLUSTER & Tamanho (pb) & $\begin{array}{c}N^{\circ} \text { de Clones } \\
\text { no Cluster }\end{array}$ & FULL & $\begin{array}{l}\text { Categoria } \\
\text { 1aria }\end{array}$ & PRODUTO & Blast & Accession $\mathrm{N}^{\circ}$ & $\%$ ID & e-value & overlap \\
\hline MCOR0479S & 449 & 1 & $P$ & $\mathrm{TNtx}$ & muscarinic toxin precursor & $x$ & $>g b|A B B 83639.1|$ & 46 & $2.00 \mathrm{E}-11$ & $36 / 77$ \\
\hline MCOR0480S & 345 & 1 & $P$ & DT & b1 gene for beta-bungarotoxin $B 1$ chain & $\mathrm{N}$ & >emb|AJ251223.1|BMU251223 & 88 & 4.00E-25 & $101 / 114$ \\
\hline MCOR0481S & 555 & 1 & FF & CE & apolipoprotein B mRNA editing enzyme & $\mathrm{x}$ & >ref|NP_001026732.1| & 98 & 4.00E-78 & $148 / 151$ \\
\hline MCOR0482S & 409 & 1 & FF & TNtx & Alpha-neurotoxin homolog 7 precursor & $\mathrm{x}$ & sp|Q9PRI1|NXAH7_MICCO & 98 & $5.00 \mathrm{E}-40$ & $76 / 77$ \\
\hline MCOR0483S & 417 & 1 & FF & TNtx & Alpha-neurotoxin homolog 7 precursor & $\mathrm{x}$ & sp|Q9PRI1|NXAH7_MICCO & 100 & $2.00 \mathrm{E}-40$ & $77 / 77$ \\
\hline MCOR0484S & 512 & 1 & $\mathrm{FF}$ & CT & ribosomal protein $\mathrm{L} 27 \mathrm{a}$ & $x$ & ref|NP_036105.2| & 86 & $1.00 \mathrm{E}-79$ & $139 / 148$ \\
\hline MCOR0485S & 400 & 1 & $P$ & OF & nuclease sensitive element binding & $\mathrm{x}$ & >ref|NP_989745.1| & 85 & $2.00 \mathrm{E}-26$ & $57 / 67$ \\
\hline MCOR0486S & 409 & 1 & $P$ & TNtx & Alpha-neurotoxin homolog 8 precursor & $x$ & sp|P58370|NXAH8_MICCO & 93 & $1.00 \mathrm{E}-30$ & $58 / 62$ \\
\hline MCOR0487S & 437 & 1 & $\mathrm{FP}$ & CT & $60 S$ ribosomal protein $\mathrm{L} 13 \mathrm{a}$ & $x$ & $\mathrm{gb}|A A Z 38985.1|$ & 95 & $1.00 \mathrm{E}-74$ & $138 / 144$ \\
\hline MCOR0488S & 349 & 1 & $P$ & $\mathrm{TNtx}$ & Alpha-neurotoxin homolog 7 precursor & $x$ & sp|Q9PRI1|NXAH7_MICCO & 100 & $2.00 \mathrm{E}-30$ & $59 / 59$ \\
\hline MCOR0489S & 476 & 1 & & $\mathrm{NH}$ & no hit & & & & & \\
\hline MCOR0490S & 409 & 1 & $P$ & TNtx & Alpha-neurotoxin homolog 7 precursor & $x$ & sp|Q9PRI1|NXAH7_MICCO & 94 & $6.00 \mathrm{E}-27$ & $53 / 56$ \\
\hline MCOR0491S & 419 & 1 & $P$ & TP & phospholipase A2 & $\mathrm{x}$ & >gb|AAN60018.1| & 92 & $1.00 \mathrm{E}-42$ & $77 / 83$ \\
\hline MCOR0492S & 409 & 1 & $\mathrm{FF}$ & CT & $60 S$ ribosomal protein $L 41$ & $\mathrm{x}$ & sp|P62945|RL41_HUMAN & 100 & $2.00 \mathrm{E}-06$ & $25 / 25$ \\
\hline MCOR0493S & 449 & 1 & FF & CT & $60 S$ ribosomal protein L30 & $\mathrm{x}$ & sp|P67884|RL30_OPHHA & 97 & $7.00 \mathrm{E}-58$ & $112 / 115$ \\
\hline MCOR0494S & 493 & 1 & $P$ & TP & phospholipase A2 & $x$ & $>g b \mid$ AAN60018.1| & 96 & $2.00 \mathrm{E}-32$ & $62 / 64$ \\
\hline MCOR0495S & 444 & 1 & $P$ & TP & phospholipase A2 & $\mathrm{x}$ & $>\mathrm{gb} \mid$ AAN60018.1| & 95 & $3.00 \mathrm{E}-68$ & $116 / 121$ \\
\hline MCOR0496S & 493 & 1 & $\mathrm{FF}$ & TNtx & Alpha-neurotoxin homolog 8 precursor & $x$ & sp|P58370|NXAH8_MICCO & 95 & $1.00 \mathrm{E}-44$ & $82 / 86$ \\
\hline MCOR0497S & 382 & 1 & FF & TNtx & Alpha-neurotoxin homolog 8 precursor & $\mathrm{x}$ & sp|P58370|NXAH8_MICCO & 92 & $1.00 \mathrm{E}-42$ & $79 / 85$ \\
\hline MCOR0498S & 380 & 1 & $P$ & TNtx & isolate ctx23 cardiotoxin precursor & $\mathrm{N}$ & $>\mathrm{gb}|\mathrm{DQ} 273581.1|$ & 89 & $2.00 \mathrm{E}-52$ & $172 / 192$ \\
\hline MCOR0499S & 537 & 1 & FP & CT & ribosomal protein $\mathrm{L} 7$ & $\mathrm{x}$ & >ref|NP_001006345.1| & 88 & $6.00 \mathrm{E}-84$ & $155 / 176$ \\
\hline MCOR0500S & 518 & 1 & & $\mathrm{NH}$ & no hit & & & & & \\
\hline MCOR0501S & 287 & 1 & $P$ & UF & similar to apoA-I binding protein & $x$ & $>$ ref $\left|X P \_424208.1\right|$ & 74 & $7.00 \mathrm{E}-36$ & $71 / 95$ \\
\hline MCOR0502S & 301 & 1 & $P$ & $\mathrm{CT}$ & similar to ubiquitin and ribosomal & $x$ & gb|AAI02492.1| & 90 & $5.00 \mathrm{E}-39$ & $83 / 92$ \\
\hline
\end{tabular}




\begin{tabular}{|c|c|c|c|c|c|c|c|c|c|c|}
\hline CLUSTER & Tamanho $(\mathrm{pb})$ & $\begin{array}{c}\mathrm{N}^{\circ} \text { de Clones } \\
\text { no Cluster }\end{array}$ & FULL & $\begin{array}{c}\text { Categoria } \\
\text { 1aria }\end{array}$ & PRODUTO & Blast & Accession $\mathrm{N}^{\circ}$ & $\%$ ID & e-value & overlap \\
\hline MCOR0503S & 370 & 1 & $P$ & CE & ficolin & $x$ & >ref|NP_056652.1| & 74 & $7.00 \mathrm{E}-07$ & $23 / 31$ \\
\hline MCOR0504S & 473 & 1 & $P$ & MT & cytochrome-c oxidase subunit II & $x$ & $>\mathrm{gb} \mid$ AAL55554.1| & 79 & $3.00 \mathrm{E}-65$ & $123 / 155$ \\
\hline MCOR0505S & 474 & 1 & & $\mathrm{NH}$ & no hit & & & & & \\
\hline MCOR0506S & 521 & 1 & & $\mathrm{NH}$ & no hit & & & & & \\
\hline MCOR0507S & 454 & 1 & & $\mathrm{NH}$ & no hit & & & & & \\
\hline MCOR0508S & 561 & 1 & $P$ & $\mathrm{RT}$ & reverse transcriptase & $x$ & >dbj|BAD72127.1| & 58 & $5.00 \mathrm{E}-08$ & $33 / 56$ \\
\hline MCOR0509S & 581 & 1 & FF & TP & phospholipase A2 & $x$ & $>\mathrm{gb} \mid$ AAN60018.1| & 97 & $8.00 \mathrm{E}-81$ & $137 / 140$ \\
\hline MCOR0510S & 506 & 1 & & $\mathrm{NH}$ & no hit & & & & & \\
\hline MCOR0511S & 393 & 1 & $P$ & DT & Ohanin precursor, gene, complete cds & $\mathrm{N}$ & $>g b|D Q 103590.1|$ & 87 & $3.00 \mathrm{E}-26$ & $116 / 132$ \\
\hline MCOR0512S & 503 & 1 & FP & CT & $39 S$ ribosomal protein $L 13$, mitochondrial & $x$ & sp|Q9BYD1|RM13_HUMAN & 83 & $1.00 \mathrm{E}-79$ & $138 / 165$ \\
\hline MCOR0513S & 460 & 1 & & $\mathrm{NH}$ & no hit & & & & & \\
\hline MCOR0514S & 528 & 1 & & $\mathrm{NH}$ & no hit & & & & & \\
\hline MCOR0515S & 500 & 1 & $P$ & CT & similar to ribosomal protein S24 & $x$ & $>$ ref|XP_521519.1| & 99 & $2.00 \mathrm{E}-52$ & $101 / 102$ \\
\hline MCOR0516S & 289 & 1 & $P$ & CR & Gamma-aminobutyric acid receptor & $x$ & sp|O95166|GBRAP_HUMAN & 100 & 4.00E-08 & $26 / 26$ \\
\hline MCOR0517S & 396 & 1 & $\mathrm{FF}$ & MT & $\mathrm{NADH}$ dehydrogenase subunit $4 \mathrm{~L}$ & $x$ & $>g b|A A Y 67987.1|$ & 77 & $1.00 \mathrm{E}-30$ & $70 / 89$ \\
\hline MCOR0518S & 482 & 1 & $P$ & CT & similar to ribosomal protein $\mathrm{S} 19$ & $x$ & >ref|XP_533657.2| & 98 & $2.00 \mathrm{E}-77$ & $144 / 146$ \\
\hline MCOR0519S & 474 & 1 & $\mathrm{FP}$ & TNtx & muscarinic toxin precursor & $\mathrm{x}$ & $>g b|A B B 83639.1|$ & 65 & $2.00 \mathrm{E}-10$ & $32 / 49$ \\
\hline MCOR0520S & 516 & 1 & $P$ & TNtx & Alpha-neurotoxin homolog 8 precursor & $x$ & sp|P58370|NXAH8_MICCO & 94 & $1.00 \mathrm{E}-36$ & $66 / 70$ \\
\hline MCOR0521S & 525 & 1 & $P$ & OF & similar to lipoic acid synthetase isoform & $x$ & >ref|XP_536255.1| & 87 & 4.00E-69 & $127 / 145$ \\
\hline MCOR0522S & 497 & 1 & $\mathrm{FP}$ & CT & similar to ribosomal protein L14 & $x$ & $>$ ref $\left|X P \_418775.1\right|$ & 87 & $7.00 \mathrm{E}-67$ & $120 / 137$ \\
\hline MCOR0523S & 534 & 1 & $P$ & DN & bradykinin-potentiating/C-type natriuretic & $\mathrm{N}$ & $\mathrm{gb}|\mathrm{A} Y 310916.1|$ & 89 & 8.00E-09 & $53 / 59$ \\
\hline MCOR0524S & 194 & 1 & $P$ & TNtx & Alpha-neurotoxin homolog 8 precursor & $x$ & sp|P58370|NXAH8_MICCO & 91 & $2.00 \mathrm{E}-20$ & $43 / 47$ \\
\hline MCOR0525S & 359 & 1 & & $\mathrm{NH}$ & no hit & & & & & \\
\hline MCOR0526S & 399 & 1 & $P$ & TW & similar to WAP four-disulfide core & $x$ & >ref|XP_875467.1| & 54 & $2.00 \mathrm{E}-10$ & $26 / 48$ \\
\hline
\end{tabular}




\begin{tabular}{|c|c|c|c|c|c|c|c|c|c|c|}
\hline CLUSTER & Tamanho (pb) & $\begin{array}{c}N^{\circ} \text { de Clones } \\
\text { no Cluster }\end{array}$ & FULL & $\begin{array}{c}\text { Categoria } \\
\text { 1aria }\end{array}$ & PRODUTO & Blast & Accession $\mathrm{N}^{\circ}$ & $\%$ ID & e-value & overlap \\
\hline MCOR0527S & 528 & 1 & $\mathrm{FF}$ & $\mathrm{CR}$ & FK506-binding protein 2 precursor & $\mathrm{x}$ & sp|P45878|FKBP2_MOUSE & 82 & $2.00 \mathrm{E}-59$ & $112 / 135$ \\
\hline MCOR0528S & 573 & 1 & & $\mathrm{NH}$ & no hit & & & & & \\
\hline MCOR0529S & 494 & 1 & & $\mathrm{NH}$ & 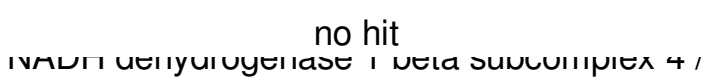 & & & & & \\
\hline MCOR0530S & 495 & 1 & $\mathrm{FF}$ & $\mathrm{CM}$ & Ndufb4 protein / NADH-ubiquinone & $x$ & gb|AAH96421.1| & 56 & $2.00 \mathrm{E}-37$ & $71 / 126$ \\
\hline MCOR0531S & 429 & 1 & $P$ & $\mathrm{CR}$ & high density lipoprotein binding protein & $x$ & sp|P81021|VIGLN_CHICK & 97 & $2.00 \mathrm{E}-73$ & $139 / 142$ \\
\hline MCOR0532S & 574 & 1 & FF & $C D$ & similar to Ufm1-conjugating enzyme 1 & $\mathrm{x}$ & $>$ ref $\left|X P \_536135.1\right|$ & 88 & $1.00 \mathrm{E}-87$ & $145 / 164$ \\
\hline MCOR0533S & 555 & 1 & FF & $\mathrm{CT}$ & $60 S$ ribosomal protein $L 18$ & $x$ & sp|P69090|RL18_OREMO & 90 & $3.00 \mathrm{E}-91$ & $164 / 181$ \\
\hline MCOR0534S & 421 & 1 & & $\mathrm{NH}$ & no hit & & & & & \\
\hline MCOR0535S & 484 & 1 & $P$ & CT & Transcription initiation factor IIA & $x$ & sp|P52657|T2AG_HUMAN & 95 & $2.00 \mathrm{E}-37$ & $76 / 80$ \\
\hline MCOR0536S & 528 & 1 & $\mathrm{P}$ & $\mathrm{CR}$ & Peroxisomal membrane protein $11 \mathrm{~B}$ & $\mathrm{x}$ & sp|O96011|PX11B_HUMAN & 63 & $3.00 \mathrm{E}-40$ & $88 / 138$ \\
\hline MCOR0537S & 646 & 1 & $P$ & UF & similar to RIKEN cDNA $1110015 \mathrm{~K} 06$ & $x$ & $>\operatorname{ref}\left|X P \_414768.1\right|$ & 94 & $E-116$ & $202 / 213$ \\
\hline MCOR0538S & 334 & 1 & $P$ & CT & Elongation factor 1-gamma (EF-1-gamma) & $x$ & sp|P29694|EF1G_RABIT & 81 & $6.00 \mathrm{E}-34$ & $67 / 82$ \\
\hline MCOR0539S & 344 & 1 & $\mathrm{FF}$ & TNtx & Short neurotoxin homolog NTL4 precursor & $\mathrm{x}$ & sp|Q9YGI8|NXSH4_BUNMU & 59 & $3.00 \mathrm{E}-22$ & $51 / 86$ \\
\hline MCOR0540S & 428 & 1 & FF & TNtx & Alpha-neurotoxin homolog 7 precursor & $\mathrm{x}$ & sp|Q9PRI1|NXAH7_MICCO & 100 & $4.00 \mathrm{E}-41$ & $78 / 78$ \\
\hline MCOR0541S & 360 & 1 & $P$ & $\mathrm{CM}$ & isocitrate dehydrogenase $2(\mathrm{NADP}+)$ & $\mathrm{x}$ & ref|NP_955858.1| & 72 & $1.00 \mathrm{E}-15$ & $37 / 51$ \\
\hline MCOR0542S & 550 & 1 & $P$ & CT & ATP-dependent RNA helicase DDX39 & $x$ & sp|O00148|DDX39_HUMAN & 96 & $2.00 \mathrm{E}-44$ & $90 / 93$ \\
\hline MCOR0543S & 431 & 1 & FF & TNtx & alpha-neurotoxin-type protein 1 & $\mathrm{x}$ & sp|Q9PUB7|NXAH1_MICCO & 100 & $5.00 \mathrm{E}-41$ & $78 / 78$ \\
\hline MCOR0544S & 561 & 1 & $P$ & $\mathrm{CM}$ & similar to 3,2-trans-enoyl-CoA isomerase & $\mathrm{x}$ & $>\mathrm{gb}|\mathrm{AAH} 78332.1|$ & 95 & $6.00 \mathrm{E}-29$ & $64 / 97$ \\
\hline MCOR0545S & 456 & 1 & $P$ & $\mathrm{CE}$ & Microtubule-associated protein RP/EB & $x$ & sp|Q66HR2|MARE1_RAT & 64 & $4.00 \mathrm{E}-48$ & $98 / 152$ \\
\hline MCOR0546S & 458 & 1 & $\mathrm{FF}$ & TNtx & Alpha-neurotoxin homolog 8 precursor & $x$ & sp|P58370|NXAH8_MICCO & 80 & $5.00 \mathrm{E}-33$ & $69 / 86$ \\
\hline MCOR0547S & 307 & 1 & $\mathrm{P}$ & OF & ADP/ATP carrier protein & $x$ & $>\mathrm{gb}|\mathrm{AAB} 96347.1|$ & 88 & $5.00 \mathrm{E}-47$ & $90 / 102$ \\
\hline MCOR0548S & 600 & 1 & $P$ & OF & CD9 antigen & $\mathrm{x}$ & >ref|NP_990093.1| & 55 & $3.00 \mathrm{E}-26$ & $57 / 102$ \\
\hline MCOR0549S & 588 & 1 & & $\mathrm{NH}$ & no hit & & & & & \\
\hline MCOR0550S & 528 & 1 & $P$ & TNtx & ctx-1 gene, exons $1-3$ & $\mathrm{~N}$ & >emb|AJ238736.1|NNA238736 & 86 & $3.00 \mathrm{E}-11$ & $75 / 87$ \\
\hline
\end{tabular}




\begin{tabular}{|c|c|c|c|c|c|c|c|c|c|c|}
\hline CLUSTER & Tamanho (pb) & $\begin{array}{c}\mathrm{N}^{\circ} \text { de Clones } \\
\text { no Cluster }\end{array}$ & FULL & $\begin{array}{c}\text { Categoria } \\
1 \text { aria } \\
\end{array}$ & PRODUTO & Blast & Accession $\mathrm{N}^{\circ}$ & $\%$ ID & e-value & overlap \\
\hline MCOR0551S & 378 & 1 & $\mathrm{P}$ & TB & natriuretic peptide & $\mathrm{X}$ & gb|AAC60341.1| & 77 & 7.00E-22 & $55 / 71$ \\
\hline MCOR0552S & 465 & 1 & $\mathrm{FF}$ & TNtx & Cytotoxin 7 precursor (Cardiotoxin 7) & $x$ & sp|P49122|CX7_NAJAT & 51 & $5.00 \mathrm{E}-16$ & $42 / 82$ \\
\hline MCOR0553S & 339 & 1 & $\mathrm{P}$ & MT & Dinodon semicarinatus mitochondrion & & >ref|NC_001945.1| & 84 & $2.00 \mathrm{E}-42$ & $240 / 284$ \\
\hline MCOR0554S & 272 & 1 & & $\mathrm{NH}$ & no hit & & & & & \\
\hline MCOR0555S & 413 & 1 & $\mathrm{FF}$ & TNtx & Alpha-neurotoxin homolog 7 precursor & $\mathrm{X}$ & sp|Q9PRI1|NXAH7_MICCO & 98 & $6.00 \mathrm{E}-37$ & $72 / 73$ \\
\hline MCOR0556S & 463 & 1 & $\mathrm{P}$ & CD & autocrine motility factor receptor & $\mathrm{X}$ & $>$ gb|AAD56722.1| & 74 & $2.00 \mathrm{E}-58$ & $116 / 155$ \\
\hline MCOR0557S & 455 & 1 & $\mathrm{FF}$ & TNtx & Alpha-neurotoxin homolog 7 precursor & $x$ & sp|Q9PRI1|NXAH7_MICCO & 100 & $4.00 \mathrm{E}-41$ & $78 / 78$ \\
\hline MCOR0558S & 528 & 1 & & $\mathrm{NH}$ & no hit & & & & & \\
\hline MCOR0559S & 537 & 1 & $\mathrm{P}$ & CT & similar to Rpl24 protein & $x$ & $>$ ref|XP_416616.1| & 95 & $2.00 \mathrm{E}-80$ & $152 / 160$ \\
\hline MCOR0560S & 483 & 1 & & $\mathrm{NH}$ & no hit & & & & & \\
\hline MCOR0561S & 568 & 1 & $\mathrm{P}$ & $\mathrm{CP}$ & Translocon-associated protein delta & $X$ & sp|Q62186|SSRD_MOUSE & 79 & $6.00 \mathrm{E}-70$ & $129 / 162$ \\
\hline MCOR0562S & 584 & 1 & & $\mathrm{NH}$ & 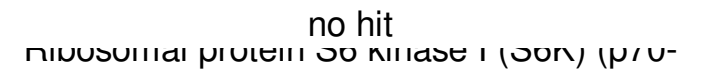 & & & & & \\
\hline MCOR0563S & 553 & 1 & $\mathrm{P}$ & CR & S6K) & $\mathrm{X}$ & sp|Q8BSK8|KS6B1_MOUSE & 83 & $1.00 \mathrm{E}-47$ & $89 / 107$ \\
\hline MCOR0564S & 407 & 1 & FP & CT & $40 S$ ribosomal protein S7 & $\mathrm{X}$ & sp|P62081|RS7_HUMAN & 90 & $1.00 \mathrm{E}-34$ & $79 / 87$ \\
\hline MCOR0565S & 527 & 1 & $\mathrm{P}$ & MT & NADH-ubiquinone oxidoreductase & $X$ & sp|O79557|NU6M_DINSE & 70 & $4.00 E-39$ & $84 / 119$ \\
\hline MCOR0566S & 415 & 1 & $\mathrm{FF}$ & CT & $40 S$ ribosomal protein S26 & $x$ & sp|P62854|RS26_HUMAN & 98 & $7.00 \mathrm{E}-62$ & $113 / 115$ \\
\hline MCOR0567S & 331 & 1 & $\mathrm{P}$ & UF & musculoskeletal, embryonic nuclear & $X$ & ref|NP_995325.1| & 68 & $6.00 \mathrm{E}-09$ & $33 / 48$ \\
\hline MCOR0568S & 423 & 1 & FF & TNtx & Alpha-neurotoxin homolog 7 precursor & $X$ & sp|Q9PRI1|NXAH7_MICCO & 100 & $4.00 \mathrm{E}-41$ & $78 / 78$ \\
\hline MCOR0569S & 275 & 1 & $\mathrm{P}$ & TNtx & Alpha-neurotoxin homolog 7 precursor & $X$ & sp|Q9PRI1|NXAH7_MICCO & 97 & $2.00 \mathrm{E}-20$ & $43 / 44$ \\
\hline MCOR0570S & 457 & 1 & FF & MT & similar to Ubiquinol-cytochrome c reductase & $X$ & ref|XP_850254.1 & 74 & $2.00 \mathrm{E}-31$ & $68 / 91$ \\
\hline MCOR0571S & 400 & 1 & FF & TNtx & Alpha-neurotoxin homolog 7 precursor & $\mathrm{X}$ & sp|Q9PRI1|NXAH7_MICCO & 100 & $6.00 \mathrm{E}-40$ & $76 / 76$ \\
\hline MCOR0572S & 466 & 1 & & $\mathrm{NH}$ & no hit & & & & & \\
\hline MCOR0573S & 410 & 1 & & $\mathrm{NH}$ & no hit & & & & & \\
\hline MCOR0574S & 234 & 1 & & $\mathrm{NH}$ & no hit & & & & & \\
\hline
\end{tabular}




\begin{tabular}{|c|c|c|c|c|c|c|c|c|c|c|}
\hline CLUSTER & Tamanho (pb) & $\begin{array}{c}N^{\circ} \text { de Clones } \\
\text { no Cluster }\end{array}$ & FULL & $\begin{array}{c}\text { Categoria } \\
\text { 1aria }\end{array}$ & PRODUTO & Blast & Accession $\mathrm{N}^{\circ}$ & $\%$ ID & e-value & overlap \\
\hline MCOR0575S & 516 & 1 & FP & CT & $60 S$ ribosomal protein $\mathrm{L} 18 \mathrm{a}$ & $x$ & sp|Q02543|RL18A_HUMAN & 98 & 2.00E-92 & $163 / 166$ \\
\hline MCOR0576S & 519 & 1 & $P$ & UF & ancient ubiquitous protein 1 isoform 2 & $x$ & >ref|NP_001015555.1| & 48 & $3.00 \mathrm{E}-25$ & $63 / 131$ \\
\hline MCOR0577S & 461 & 1 & $P$ & OF & Ewing sarcoma breakpoint region 1 & $x$ & gb|AAH68226.1| & 85 & $4.00 \mathrm{E}-73$ & $131 / 153$ \\
\hline MCOR0578S & 457 & 1 & $P$ & RT & transposon protein, putative, CACTA & $x$ & gb|AAP51898.1| & 34 & 7.00E-06 & $33 / 96$ \\
\hline MCOR0579S & 532 & 1 & FP & OF & grancalcin & $x$ & sp|Q8VC88|GRAN_MOUSE & 63 & $4.00 \mathrm{E}-43$ & $87 / 136$ \\
\hline MCOR0580S & 507 & 1 & & $\mathrm{NH}$ & no hit & & & & & \\
\hline MCOR0581S & 553 & 1 & $\mathrm{FF}$ & CT & Histone deacetylase complex subunit & $x$ & sp|O00422|SAP18_HUMAN & 98 & $1.00 \mathrm{E}-83$ & $150 / 153$ \\
\hline MCOR0582S & 417 & 1 & $P$ & CR & phospholipase $C$ beta type & $x$ & gb|AAA03065.1| & 71 & $5.00 \mathrm{E}-47$ & $99 / 139$ \\
\hline MCOR0583S & 408 & 1 & $P$ & MT & Cytochrome b & $x$ & sp|Q9MLI9|CYB_MICFL & 87 & $2.00 \mathrm{E}-59$ & $114 / 131$ \\
\hline MCOR0584S & 428 & 1 & $\mathrm{FF}$ & $\mathrm{TNtx}$ & Alpha-neurotoxin homolog 7 precursor & $x$ & sp|Q9PRI1|NXAH7_MICCO & 100 & $4.00 \mathrm{E}-41$ & $78 / 78$ \\
\hline MCOR0585S & 531 & 1 & & $\mathrm{NH}$ & no hit & & & & & \\
\hline MCOR0586S & 197 & 1 & & $\mathrm{NH}$ & no hit & & & & & \\
\hline MCOR0587S & 448 & 1 & FF & CT & ribosomal protein S15 isoform & $x$ & gb|AAH97585.1| & 99 & $8.00 \mathrm{E}-66$ & $123 / 124$ \\
\hline MCOR0588S & 466 & 1 & & $\mathrm{NH}$ & no hit & & & & & \\
\hline MCOR0589S & 375 & 1 & & $\mathrm{NH}$ & no hit & & & & & \\
\hline MCOR0590S & 448 & 1 & $P$ & CR & nucleotide binding protein 2 & $x$ & >ref|NP_001007834.1| & 86 & $7.00 \mathrm{E}-68$ & $127 / 146$ \\
\hline MCOR0591S & 491 & 1 & $P$ & $\mathrm{CR}$ & similar to CBL E3 ubiquitin protein ligase & $x$ & $>$ ref $\left|X P \_576396.1\right|$ & 39 & $1.00 \mathrm{E}-17$ & $60 / 153$ \\
\hline MCOR0592S & 278 & 1 & $P$ & UF & similar to Nur77 downstream protein 2 & $x$ & $>$ ref $\left|X P \_415224.1\right|$ & 83 & 2.00E-06 & $25 / 30$ \\
\hline MCOR0593S & 320 & 1 & & $\mathrm{NH}$ & no hit & & & & & \\
\hline MCOR0594S & 434 & 1 & $P$ & $\mathrm{CT}$ & Rpl17 protein & $x$ & $>\mathrm{gb}|\mathrm{AAH} 03896.2|$ & 100 & 4.00E-50 & $100 / 100$ \\
\hline MCOR0595S & 358 & 1 & $P$ & MT & NADH dehydrogenase subunit 1 & $x$ & $>g b|A A L 66854.1|$ & 85 & $3.00 \mathrm{E}-31$ & $66 / 77$ \\
\hline MCOR0596S & 479 & 1 & FP & $\mathrm{CR}$ & nucleotide binding protein 2 & $x$ & >ref|NP_001007834.1| & 80 & 4.00E-26 & $58 / 72$ \\
\hline MCOR0597C & 418 & 8 & FF & TNtx & alpha-neurotoxin-type protein 1 & $x$ & sp|Q9PUB7|NXAH1_MICCO & 100 & $5.00 \mathrm{E}-41$ & $78 / 78$ \\
\hline MCOR0598C & 427 & 6 & $\mathrm{FF}$ & $\mathrm{TNtx}$ & Alpha-neurotoxin homolog 7 precursor & $x$ & sp|Q9PRI1|NXAH7_MICCO & 98 & $1.00 \mathrm{E}-40$ & $77 / 78$ \\
\hline
\end{tabular}




\begin{tabular}{|c|c|c|c|c|c|c|c|c|c|c|}
\hline CLUSTER & Tamanho (pb) & $\begin{array}{c}N^{\circ} \text { de Clones } \\
\text { no Cluster }\end{array}$ & FULL & $\begin{array}{c}\text { Categoria } \\
\text { 1aria }\end{array}$ & PRODUTO & Blast & Accession $\mathrm{N}^{\circ}$ & $\%$ ID & e-value & overlap \\
\hline MCOR0599C & 438 & 36 & $\mathrm{FF}$ & TNtx & Alpha-neurotoxin homolog 7 precursor & $x$ & sp|Q9PRI1|NXAH7_MICCO & 100 & $4.00 \mathrm{E}-41$ & $78 / 78$ \\
\hline MCOR0600C & 423 & 25 & $\mathrm{FF}$ & TNtx & Alpha-neurotoxin homolog 7 precursor & $x$ & sp|Q9PRI1|NXAH7_MICCO & 100 & $4.00 \mathrm{E}-41$ & $78 / 78$ \\
\hline MCOR0601S & 297 & 1 & $\mathrm{P}$ & TNtx & alpha-neurotoxin-type protein 1 & $x$ & sp|Q9PUB7|NXAH1_MICCO & 100 & $1.00 \mathrm{E}-19$ & $42 / 42$ \\
\hline MCOR0602C & 598 & 2 & FF & TL & C-type lectin-like protein 2 & $x$ & $>g b|A A K 43585.1|$ & 72 & $6.00 \mathrm{E}-55$ & $91 / 126$ \\
\hline MCOR0603C & 612 & 6 & $\mathrm{FP}$ & TL & C-type lectin-like protein 2 & $x$ & $>\mathrm{gb}|\mathrm{AAK} 43585.1|$ & 71 & 3.00E-63 & $108 / 151$ \\
\hline MCOR0604C & 488 & 4 & $\mathrm{FF}$ & TNtx & Alpha-neurotoxin homolog 8 precursor & $x$ & sp|P58370|NXAH8_MICCO & 100 & $4.00 \mathrm{E}-48$ & $86 / 86$ \\
\hline MCOR0605C & 500 & 5 & $\mathrm{FF}$ & TNtx & Alpha-neurotoxin homolog 8 precursor & $x$ & sp|P58370|NXAH8_MICCO & 100 & $4.00 \mathrm{E}-48$ & $86 / 86$ \\
\hline MCOR0606S & 384 & 1 & $\mathrm{P}$ & CT & ribosomal protein S3 & $x$ & $>g b|A A D 27643.1|$ & 93 & $8.00 \mathrm{E}-29$ & $60 / 64$ \\
\hline MCOR0607S & 458 & 1 & $\mathrm{P}$ & TP & phospholipase A2 & $x$ & $>g b|A A N 60018.1|$ & 100 & 4.00E-71 & $119 / 119$ \\
\hline MCOR0608S & 335 & 1 & $P$ & TP & phospholipase A2 & $x$ & $>g b|A A N 60018.1|$ & 100 & $3.00 \mathrm{E}-45$ & $81 / 81$ \\
\hline MCOR0609S & 448 & 1 & $\mathrm{FP}$ & TP & phospholipase A2 & $x$ & $>g b|A A N 60018.1|$ & 97 & $3.00 \mathrm{E}-58$ & $104 / 107$ \\
\hline MCOR0610S & 352 & 1 & $\mathrm{FP}$ & $C D$ & ubiquitin & $x$ & gb|AAV84266.1| & 100 & $2.00 \mathrm{E}-59$ & $117 / 117$ \\
\hline MCOR0611S & 398 & 1 & FF & TK & trypsin inhibitor preproprotein & $x$ & $>g b \mid$ AAP04484.1| & 59 & $1.00 \mathrm{E}-25$ & $53 / 89$ \\
\hline
\end{tabular}

e-value: valor significativo da sequência no NR protein database

FULL?: clones parciais (P), clones inteiros mas com sequenciamento incompleto (FP) e clones inteiros e com sequências completas (FF)

\% ID: percentual da sequência obtida na comparação com o banco de dados

overlap: quanto da sequência apresenta semelhança com o banco de dados 